UNIVERSIDADE DE SÃO PAULO

FACULDADE DE FILOSOFIA, LETRAS E CIÊNCIAS HUMANAS DEPARTAMENTO DE LINGUÍSTICA PROGRAMA DE PÓS-GRADUAÇÃO EM SEMIÓTICA E LINGUÍSTICA GERAL

VANICE RIBEIRO DIAS LATORRE

UMA ABORDAGEM ETNOTERMINOLÓGICA DE GRANDE SERTÃO: VEREDAS

Versão corrigida

De acordo:

SÃO PAULO 
VANICE RIBEIRO DIAS LATORRE

\section{UMA ABORDAGEM ETNOTERMINOLÓGICA DE GRANDE SERTÃO: VEREDAS}

Dissertação apresentada ao Programa de PósGraduação em Semiótica e Linguística Geral do Departamento de Linguística da Faculdade de Filosofia, Letras e Ciências Humanas da Universidade de São Paulo, para obtenção do título de Mestre em Semiótica e Linguística Geral.

Orientadora: Prof ${ }^{a}$. Dra. Maria Aparecida Barbosa

Área de concentração: Semiótica e Linguística Geral

\section{VERSÃO CORRIGIDA \\ DE ACORDO:}

SÃO PAULO 
Nome: LATORRE, Vanice Ribeiro Dias

Título: UMA ABORDAGEM ETNOTERMINOLÓGICA DE GRANDE SERTÃO: VEREDAS

Dissertação apresentada ao Programa de Pós-Graduação em Semiótica e Linguística Geral do Departamento de Linguística da Faculdade de Filosofia, Letras e Ciências Humanas da Universidade de São Paulo, para obtenção do título de Mestre em Semiótica e Linguística Geral.

\section{BANCA EXAMINADORA}

APROVADA em 24 de fevereiro de 2012

Prof $^{a}$. Dr ${ }^{\mathrm{a}}$. Maria Vicentina de Paula do Amaral Dick

Instituição: Universidade de São Paulo

Julgamento:

Assinatura:

Prof $^{a}$. Dr ${ }^{a}$. Marieta Prata de Lima Dias

Instituição: Universidade Federal de Mato Grosso - Campus SINOP Julgamento:

Assinatura:

Prof ${ }^{\mathrm{a}}$. Dra ${ }^{\mathrm{a}}$. Maria Aparecida Barbosa (Orientadora)

Instituição: Universidade de São Paulo

Julgamento:

Assinatura: 
Dedico meu Mestrado, desde o primeiro momento, e esta Dissertação, aos meus filhos Bruno e Nathália. 


\section{AGRADECIMENTOS}

Agradeço à minha grande mestra, Prof ${ }^{\mathrm{a}}$. Dr ${ }^{\mathrm{a}}$. Maria Aparecida Barbosa que, ao confiar em mim, me possibilitou realizar este trabalho. Valorizou, durante todo meu percurso, as minhas descobertas, me entusiasmando desde os primeiros momentos em que esse tema foi gerado. Sua orientação segura, de valor inestimável, me possibilitou sentir o prazer e a alegria que só sente quem aprendeu mais um pouco.

Agradeço à minha família pelo apoio: aos meus pais Eugenia e José, minhas raízes, o começo de tudo e a quem devo a vida; ao meu marido, Nilton Rafael Latorre, por seu incentivo constante e disponibilidade para refletir comigo sempre que precisei, embora os assuntos lhe fossem tão estranhos, e também, pela paciência com que ouviu minhas leituras, nos momentos em que a atenção do ouvinte é tão necessária para ouvirmos a nós mesmos; aos meus filhos meu presente maior de Deus.

Agradeço às minhas queridas mestras, com os quais tive a oportunidade de conviver, aprender e das quais para sempre vou lembrar, com grande carinho, especialmente a Prof ${ }^{\mathrm{a}}$. Dr $^{\mathrm{a}}$. Ieda Maria Alves, a Prof ${ }^{\mathrm{a}}$. Dr ${ }^{\mathrm{a}}$. Maria Vicentina de Paula do Amaral Dick e a Prof ${ }^{\mathrm{a}}$ Dra $^{\mathrm{a}}$ Nilce Sant'Anna Martins.

Agradeço aos amigos de sempre, cuja amizade teve início nos bancos desta faculdade há tantos anos: Nilcéa Hernandes Farina, com quem reiniciei essa caminhada, retomando um sonho antigo, e Orlando Augusto Pinto, que dedicou seu tempo e competência à leitura, revisão dos originais e inteligentes observações acerca dos seus conteúdos, como já fazia nos tempos de outrora.

Agradeço a todos com os quais tive o privilégio de ter tido contato: Prof. Dr. Hudinilson Urbano, Prof ${ }^{a}$. Dr ${ }^{a}$ Mariangela de Araújo, Prof ${ }^{a}$. Dr ${ }^{a}$. Stella O. Tagnin; e aos amigos conquistados que de formas diferentes estiveram ao meu lado: Albelita Lourdes Monteiro Cardoso, Angela M. T. Zucchi, Dora Guimarães, José Oswaldo dos Santos (Brasinha), Luciana Pissolato, Mauro Gomes de Paulo, Thiago Carvalho Gaudêncio, e a Eduardo Carvalho Tess com quem pude viver a emoção de ouvir o pouco mais de Rosa que não aprenderia nos livros.

Aos amigos que souberam entender minhas ausências, sou grata.

Finalmente, agradeço a Deus pela oportunidade de mais esse engrandecimento da minha experiência humana. Poderia meu tema ser mais instigante do que uma releitura da produção linguística de Guimarães Rosa, em sua multiplicidade de significados a permitir 
infinitas releituras e, como fonte de conhecimento, permitir voos cada vez mais altos? Tenho razões de sobra para me sentir privilegiada. 
"A vida inventa! A gente principia as coisas, no não saber por que, e desde aí perde o poder de continuação - porque a vida é mutirão de todos, por todos remexida e temperada." 


\section{RESUMO}

LATORRE, Vanice Ribeiro Dias. Uma abordagem etnoterminológica de Grande Sertão: Veredas. 2011. 156 f. Dissertação (Mestrado) - Faculdade de Filosofia, Letras e Ciências Humanas da Universidade de São Paulo. Departamento de Linguística. Área de concentração: Semiótica e Linguística Geral.

Propusemo-nos, nesta Dissertação de Mestrado, a analisar a unidade mínima de significação da Etnoterminologia no léxico de Grande Sertão: Veredas, em sua vertente etnoliterária, para compreender como a realidade fenomênica é refletida na axiologia do grupo sócio-linguísticocultural do sertanejo dos gerais. Analisamos, em suas diferentes etapas, o processo de conceptualização de alguns vocábulos-termos de algumas denominações da obra. Tal processo se dá no percurso gerativo da enunciação e é constituído por conjuntos de semas conceptuais, os noemas. A análise linguística desvelou como as denominações, produto do fazer persuasivo do sujeito enunciador, originam-se nas qualidades conceituais da cognição e são materializadas em traços semânticos específicos, ou nos conceitos de cada unidade lexical, integrando o processo de modalização. Pudemos observar que o conceptus, em sentido amplo, parte, em sua trajetória do natural, em direção ao cultural, e se expande com o acréscimo de semas conceptuais formadores que se organizam em dois conjuntos: os de natureza cultural e ideológica e aqueles de natureza modalizante e intencional. Guimarães Rosa transplantou suas pesquisas linguísticas para seus textos, ao abrigo das denominações, e realçou significantes amalgamados a conceitos portadores de exclusividades semânticas que se erigem na própria especificidade que nomeia os seres, resultado dos conhecimentos herdados e amealhados ao longo de gerações. É nessa exclusividade semântica que a fronteira existente entre o vocábulo e o termo das linguagens de especialidades torna-se densa em seu romance, e é, nesses limites, que se apresenta o vocábulo-termo, no qual o autor encontra a palavra vigorosa, profunda e não desgastada pelo uso impróprio. Verificamos, sobretudo, a partir da análise das palavras escolhidas por nós, a gênese do vocábulo-termo nas especifidades linguísticas regionais e que desenha etnicamente a identidade de um grupo. Sabemos que em todas as obras de Rosa se verifica, em maior ou menor proporção, o uso das virtualidades que o sistema linguístico oferece aos seus falantes, e a abordagem dos aspectos sociolinguísticos, convergindo para o semantismo inusitado do vocábulo-termo rosiano, colaborou, do nosso ponto de vista, para melhor caracterizá-las em sua vertente etnoliterária. 
A análise dos vocábulos-termos de Grande Sertão: Veredas evidencia o processo de ressemantização da palavra usada na língua geral. Ou seja, novos sememas enriquecem a unidade léxica e, também, a experiência de quem se aproxima do texto, ao realizar-se em aspectos referenciais, pragmáticos e simbólicos, constituindo-se, simultaneamente, em documento semântico e social de uma cultura. As palavras de uso em língua geral se constituem em signos-símbolos em Grande Sertão: Veredas.

Palavras-chave: Etnoterminologia. Lexicologia. Semântica Cognitiva. Semiótica. 


\begin{abstract}
An ethno terminological approach of "Grande Sertão: Veredas"

In this Master's Dissertation we have proposed to analyze the minimal unit of meaning in the Ethno-terminology in the lexicon of "Grande Sertão: Veredas", in its ethnoliterary aspect, in order to understand how the reality of phenomenon is reflected in the axiology of the social-linguistic-cultural group of the sertanejo dos gerais. We have analyzed, in its different stages, the process of conceptualization of some word-terms of some of the work's denominations. Such process takes place in the generative trajectory of enunciation and is constituted by groups of conceptual semes, the nemes. The linguistic analysis revealed how the denominations, result of the persuasiveness of the announcer subject, originate in the conceptual qualities of cognition and are materialized in specific semantic traits, or in the concepts of each lexical unit, integrating the modalization process. We could observe that the conceptus, in its broad meaning, moves from its natural trajectory towards the cultural, and expands with the addition of conceptual semes which get organized in two groups: the ones with a cultural and ideological nature and the ones with a modalizing and intentional nature. Guimarães Rosa transplanted his linguistic research to his texts, to the protection of denominations, and enhanced the significants tied to concepts bearing semantic exclusivities which build from the specificity that names the beings, result of the knowledge inherited and grouped over generations. It is in this semantic exclusivity that the frontier that exists between word and term of the languages of specialities become dense in his novel, and it is, in those boundaries, that the word-term presents itself, in which the author finds words which are vigorous, profound and not wasted by inappropriate use. We have verified, especially, in the analysis of words chosen by us, the genesis of the word-term in the regional linguistic specificities and which draws ethnically the identity of a group. We are aware that in every of Rosa's work, in a smaller or bigger proportion, we verify the use of the virtuality that the linguistic system offers to its speakers, and the approach of the sociolinguistic aspects, converging to an unused semantics of the word-term in Rosa, which collaborated, in our point of view, to better characterize them in this ethno literary aspect. The analysis of the word-terms in "Grande Sertão: Veredas" demonstrates a resemantic process of the word used in the general language. That is, new sememes enrich the lexical unit, and also, the experience of those who approach the text, in referential, pragmatic and symbolic aspects,
\end{abstract}


constituting, simultaneously, a semantic and social document of a culture. The words in use in general language constitute symbol-signs in "Grande Sertão: Veredas".

Key-words: Ethno terminology; Lexicology; Cognitive semantics; Semiotics. 


\section{RÉSUMÉ}

Dans ce Mémoire de Master nous nous proposons d'analyser l'unité minimale de signification de l'Ethno-terminologie dans le lexique de Grande Sertão : Veredas dans son aspect ethnolittéraire, pour comprendre la façon dont la réalité phénoménique se reflète dans l'axiologie $\mathrm{du}$ groupe socio-linguistique-culturel du sertanejo dos gerais ${ }^{1}$. Nous analysons dans leurs différentes étapes le processus de conceptualisation de certains vocables-termes de quelques dénominations présentes dans l'œuvre. Ce processus a lieu dans le parcours génératif de l'énonciation et est constitué de groupes de sèmes conceptuels, les noèmes. L'analyse linguistique a révélé la façon dont les dénominations (le produit de «l'acte de faire » persuasif du sujet énonciateur) se forgent dans les qualités conceptuelles de la cognition et se matérialisent dans des traits sémantiques spécifiques ou dans les concepts de chaque unité lexicale, en intégrant le processus de modalisation. Nous avons pu également observer que le conceptus, dans un sens plus large, va (dans sa trajectoire du naturel) vers le culturel et s'étend avec l'ajout de sèmes conceptuels formateurs qui s'organisent en deux groupes : ceux de nature culturelle et idéologique, et ceux de nature modalisatrice et intentionnelle. Guimarães Rosa a transféré ses recherches linguistiques à ses textes, à l'abri des dénominations, et a mis en évidence des signifiants amalgamés à des concepts porteurs d'exclusivités sémantiques qui se dressent dans la spécificité même qui nomme les êtres, résultat des connaissances héritées et accumulées tout au long de générations. C'est dans cette exclusivité sémantique que la frontière entre le vocable et le terme des langages de spécificité devient dense dans son roman, et c'est dans ces limites qui se présente le vocable-terme, dans lequel l'auteur retrouve le mot vigoureux, profond et non-usé par un usage impropre. Nous avons vérifié, surtout à partir de l'analyse des mots sélectionnés, la genèse du vocable-terme dans les spécificités linguistiques régionales et qui dessinent ethniquement l'identité d'un groupe. Nous n'ignorons pas que dans toutes les œuvres de Rosa nous retrouvons, en plus grande ou plus petite proportion, l'usage des virtualités que le système linguistique offre à ses parlants, et l'approche des aspects sociolinguistiques qui convergent au sémantisme inouï du vocable-terme de Rosa, ce qui à notre avis a collaboré pour les caractériser mieux dans son versant ethno-littéraire. L'analyse des vocables-termes de Grande Sertão : Veredas met en

\footnotetext{
${ }^{1}$ Le «Sertão » est une zone géographique qui va du Nord de l'état de Minas Gerais au Nord-Est du Brésil ayant un climat aride ou semi-aride. Région plutôt rurale, ses habitants (les «sertanejos») apparaissent fréquemment dans la littérature brésilienne et ont un langage très spécifique et particulier par rapport au langage courant du portugais brésilien (N.T.) .
} 
évidence le processus de resémantisation du mot utilisé dans le langage ordinaire, soit de nouveaux sémèmes enrichissent l'unité lexique et aussi l'expérience de celui qui s'approche du texte, en se réalisant dans des aspects référentiels, pragmatiques et symboliques, en se construisant simultanément en document sémantique et social d'une culture. Les mots d'usage en langue ordinaire se constituent en signes-symboles dans Grande Sertão : Veredas.

Mots-clés : Ethno-terminologie. Lexicologie. Sémantique Cognitive. Sémiotique. 


\section{LISTA DAS FICHAS ETNOTERMINOLÓGICAS}

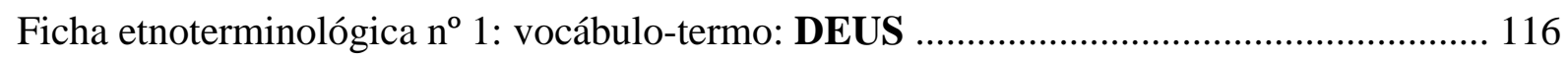

Ficha etnoterminológica $n^{\circ}$ 2: vocábulo-termo: SERTÃO …........................................... 117

Ficha etnoterminológica $n^{\circ}$ 3: vocábulo-termo: JAGUNÇO ......................................... 118

Ficha etnoterminológica $n^{\circ} 4$ : vocábulo-termo: VENTO (S) ......................................... 119

Ficha etnoterminológica $\mathrm{n}^{\circ}$ 5: vocábulo-termo: GERAIS) .......................................... 120

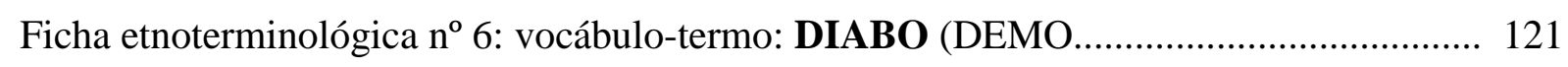

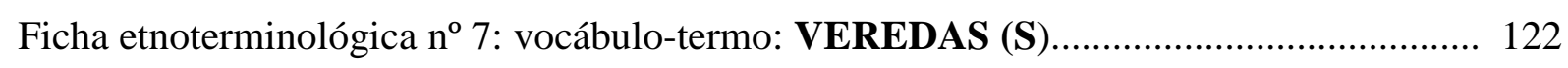

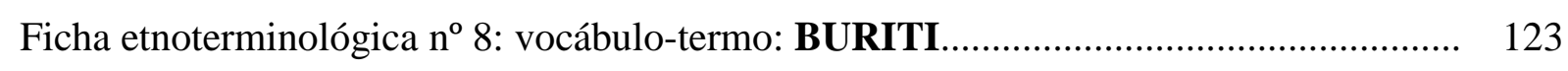

Ficha etnoterminológica $n^{\circ}$ 9: vocábulo-termo: PORTO............................................... 124

Ficha etnoterminológica $\mathrm{n}^{\circ}$ 10: vocábulo-termo: URUCUIANO …................................. 125

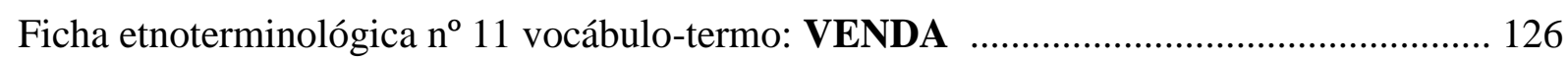

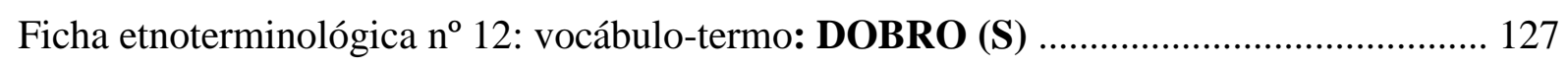

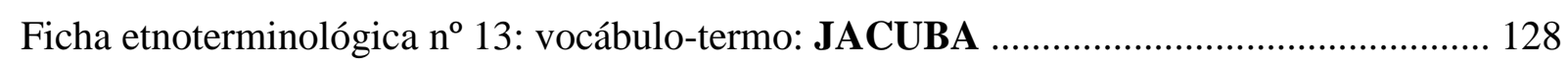

Ficha etnoterminológica $\mathrm{n}^{\circ}$ 14: vocábulo-termo: RESFRIADO ..........................................129

Ficha etnoterminológica $n^{\circ}$ 15: vocábulo-termo: ZURETA (ZURETADO) ........................ 130

Ficha etnoterminológica $n^{\circ}$ 16: vocábulo-termo: CROA-COM-ILHA .............................. 131

Ficha etnoterminológica $\mathrm{n}^{\circ}$ 17: vocábulo-termo: QUIZILIA ...............................................132

Ficha etnoterminológica $n^{\circ} 18$ : vocábulotermo: RASTREADOR(ES ) .............................133

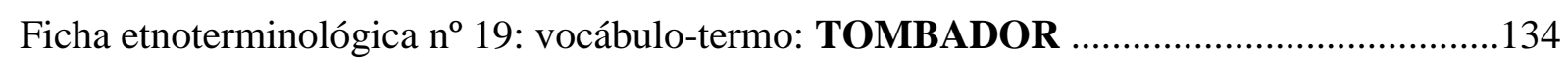

Ficha etnoterminológica $n^{\circ}$ 20: vocábulo-termo ARCO-ÍRIS .............................................135

Ficha etnoterminológica nº 21: vocábulo-termo: CABAÇA BEM TAPADA E

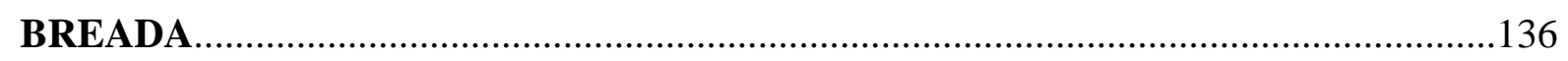

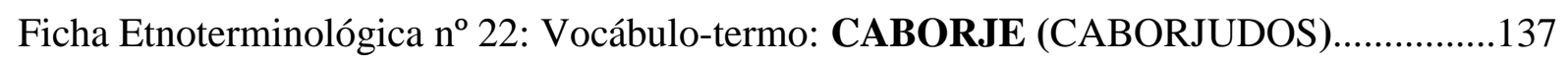

Ficha Etnoterminológica n ${ }^{\mathrm{o}} 23$ : Vocábulo-termo CATRUMANOS:....................................138

Ficha Etnoterminológica n ${ }^{\circ}$ 24: Vocábulo-termo: JANUÁRIA............................................139

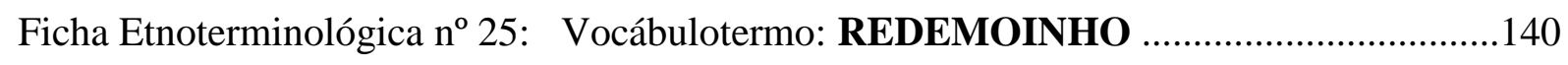




\section{SUMÁRIO*}

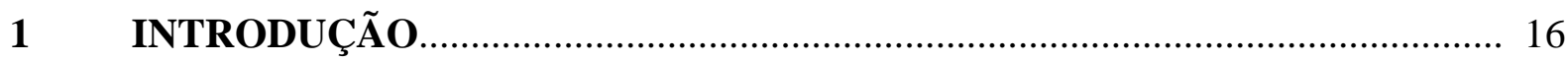

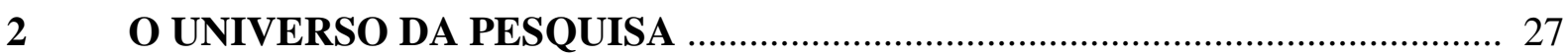

2.1 Elementos históricos e geográficos na constituição do Estado de Minas Gerais....... 27

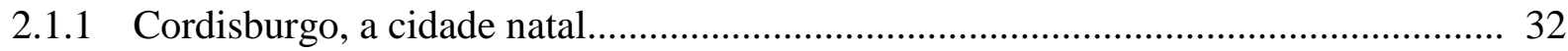

2.2 Guimarães Rosa: o homem, o autor e a linguagem............................................ 35

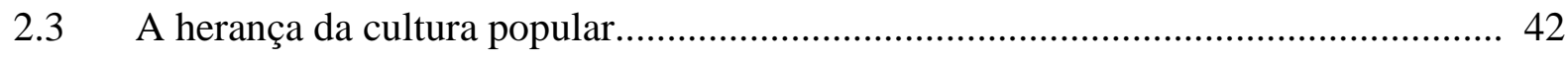

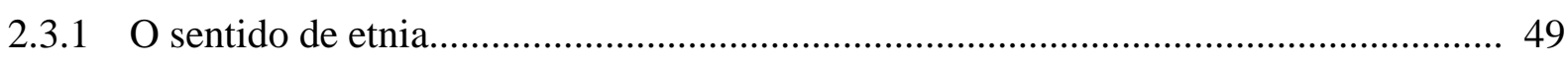

2.3.2 A concepção de mundo e sua relação com as palavras........................................... 51

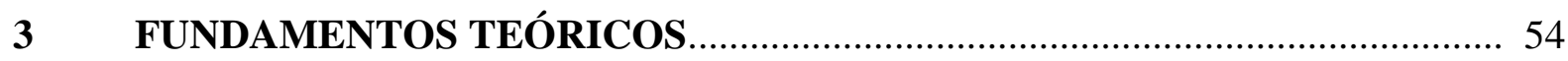

3.1 A renovação das estruturas lexicais e sua interação com a evolução do saber.......... 54

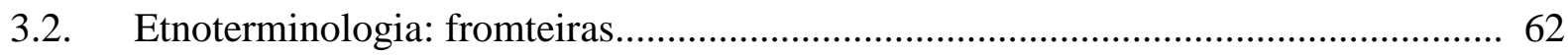

3.2.1 A unidade mínima de significação da Etnoterminologia: o vocábulo- termo............ 68

3.2.2 Das modalizações discursivas na Etnoterminologia........................................... 70

3.3 A formação do conceito nos discursos etnoliterários........................................... 73

3.4 Aspectos sociolinguísticos da gênese da unidade lexical.................................... 80

3.4.1 As denominações e suas especificidades............................................................. 91

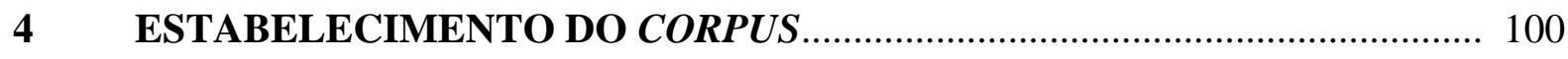

4.1 Perfil do texto constitutivo do corpus................................................................. 100

4.2 A Linguística de Corpus como instrumento de seleção de palavras-chave............ 102

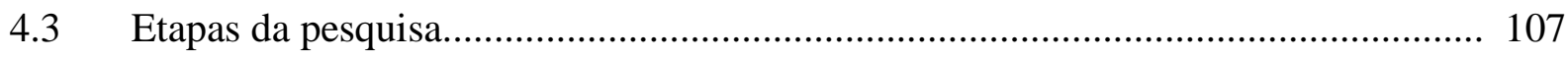

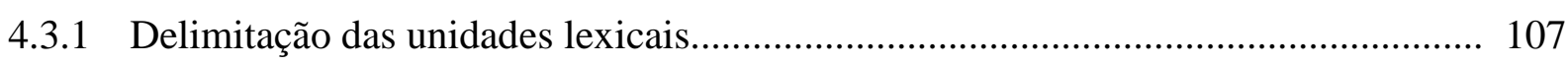

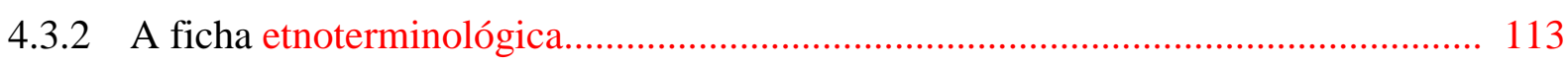

5 ANÁLISE DOS VOCÁBULOS -TERMOS: FORMAÇÃO CONCEITUAL... 115

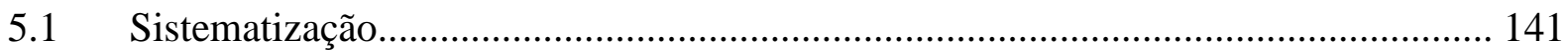

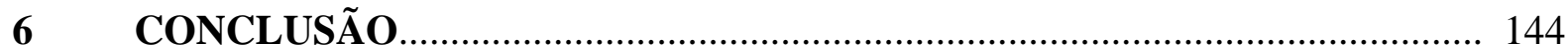

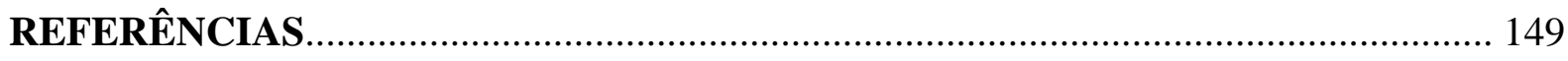

* De acordo com as normas do SIBi/USP. 


\title{
INTRODUÇÃO
}

\author{
"Toda ação principia mesmo é por uma palavra pensada" \\ In: "Grande Sertão: Veredas",
}

Guimarães Rosa

De quantos pontos de vista a obra de Guimarães Rosa já não terá sido analisada e através de quantos olhares ainda será possível considerá-la?

A comparação entre esta pesquisa e tantas outras de renomados pesquisadores é inevitável, inclusive revelando as limitações deste trabalho que é, entretanto, uma séria tentativa de resultados que possam contribuir com os estudos da linguagem, sob uma perspectiva científica que a Etnoterminologia pode oferecer com seu suporte teórico. Também já escreveu Rosa: a gente está sempre precisando de coisas sérias, assim, como confirmação e para ajuda ${ }^{l}$. A obra de Guimarães Rosa, por sua vez, é fonte de pesquisa inesgotável e de mistérios linguísticos para os que, como ele, são amantes da língua e juntos com ela procriam. $^{2}$

Recorremos à tantas vezes repetida, mas sempre tão oportuna citação de Saussure: C'est le point de vue que crée l'object ${ }^{3}$ para argumentarmos contrariamente quanto a possíveis críticas.

O ponto de vista através do qual escolhemos empreender a análise do nosso objeto, tendo sido concebido individual e intuitivamente, é por si só um recorte original, e se apropria de uma das possíveis dimensões de análise do léxico rosiano: suas denominações sob uma perspectiva etnoterminológica.

A inspiração para o projeto de Dissertação de Mestrado que apresentamos à banca do nosso Exame de Qualificação teve origem no transcorrer da disciplina Elementos de

\footnotetext{
${ }^{1}$ BIZARRI, Edoardo. João Guimarães Rosa: Correspondência com seu Tradutor Italiano. Rio de Janeiro: Nova Fronteira, 2006, p. 18.

${ }^{2}$ Grandes Entrevistas - Guimarães Rosa 2. Disponível em: <HTTP://www.tirodeletra.com.br/entrevistas/GuimarãesRosa-1965.htm> p.16. Acesso em: 09 de jun. 2011.

${ }^{3}$ SAUSSURE, Ferdinand de. Curso de Linguística Geral. São Paulo. Editora Cultrix, 1971. p. 15. (É o ponto de vista que cria o objeto).
} 
Etnolinguística e Etnotoponímia, ministrada pela $\operatorname{Prof}^{a} \operatorname{Dr}^{\mathrm{a}}$. Maria Vicentina de Paula do Amaral Dick, por nós cursada por sugestão da nossa orientadora, Prof ${ }^{a}$. Dr ${ }^{\mathrm{a}}$. Maria Aparecida Barbosa.

Quando da solicitação de um seminário pela Prof ${ }^{a}$ Dr. ${ }^{a}$ Maria Vicentina de Paula do Amaral Dick, por não estarmos engajada em nenhuma pesquisa ou levantamento toponímico específico, surgiu a ideia de iniciarmos um trabalho partindo da resposta dada por Guimarães Rosa ao seu tradutor italiano sobre o significado da palavra vereda, tomando-a como um designativo toponímico.

Estamos nos referindo justamente à instigante dinâmica linguística que revela representações acerca dos fatos, concepções e visões de mundo, convenções culturais, tradições, crenças, formas de perceber, sentir, pensar e simbolizar a realidade: o discurso etnoliterário materializado no conteúdo conceptual e semântico atualizado por Guimarães Rosa, com sua reconhecida e rigorosa precisão, conteúdos desvelados nos traços específicos ou nos conceitos de cada unidade lexical, inventada ou reinventada em sua obra.

Tendo tomado conhecimento da excelente obra de Nilce Sant`Anna Martins, O Léxico de Guimarães Rosa, presumimos que esta poderia, em boa medida, contribuir para a pesquisa que se configurava, supondo que vários outros topônimos surgiriam desse inventário.

No levantamento e na escolha dos topônimos e antropônimos ali relacionados, consideramos como eixo norteador as denominações sertanejas enquanto caracterizadoras de uma realidade muito particular, impenetrável e exata.

Tomamos a palavra denominativa como uma construção do homem, no seu valor de construção do ambiente e espelho desse ambiente, a linguagem enquanto instrumento que favorece sua percepção para todos os outros homens (a palavra é geradora e, ao mesmo tempo, reflexo da construção do mundo). Naturalmente, a pesquisa e a análise no contexto literário foram necessárias e o reencontro com pelo menos uma das obras de Rosa foi obrigatório. Assim, acrescentamos a leitura de Grande Sertão: Veredas como mais um instrumento de pesquisa e análise das denominações.

A difícil tarefa de apropriar-se de outra realidade, portanto de outra visão de mundo, gerou documentos de imensa importância entre Rosa, o autor, e vários de seus tradutores.

O convite, porém, para "vestir a roupa de campeiro, montado em um cavalo malhado e saindo por essas chapadas e veredas sertanejas nossas" ${ }^{\text {"4 }}$ para melhor poder entender sua língua, foi rigorosamente aceito pelos mais famosos de seus tradutores.

\footnotetext{
${ }^{4}$ BIZZARRI, Edoardo. João Guimarães Rosa: Correspondência com seu Tradutor Italiano. Rio de Janeiro: Nova Fronteira, 2006, p.190.
} 
Estimulados as reflexões e liberdades, os voos por cima ("Vôe por cima, e adapte, quando e como bem lhe parecer"” $)^{5}$, a criação literária foi compartilhada humildemente com seus tradutores, tão importantes eram para Rosa seus "eventuais leitores" de outras línguas. Seus processos de criação foram generosamente expostos, para que seus tradutores pudessem penetrar no cenário linguístico, "exótico e mal conhecido", , em que Rosa tão bem inseriu o sertanejo do sertão dos Gerais, em meio à excepcional descrição de cada detalhe que o cercava, em meio à riqueza de denominações da fauna, flora, crenças, valores e sentimentos, da etnicidade, enfim, que define o sertanejo e seu sertão de maneira ímpar.

No livro Guimarães Rosa, Correspondência com seu Tradutor Italiano, em carta datada de 06 de outubro de 1963, Edoardo Bizzari registra o abismo que subjaz ao entendimento da realidade fenomênica pelos diversos grupos humanos ou mesmo entre indivíduos, preocupado com os leitores que ainda não teriam sido introduzidos no mundo do sertão. Processada conceptualmente de modos diversos, cada realidade resulta em diferentes modelos que refletem a axiologia própria de cada grupo ou indivíduo.

O tradutor italiano queria saber o significado de uma palavra que não fazia parte do seu universo linguístico e referencial, o designativo "vereda", termo recorrente em inúmeras e inúmeras passagens na obra de Rosa.

Assim explicou-se Bizarri, em uma das primeiras cartas que enviou a Rosa, enquanto preparava a tradução de Manuelzão e Miguilim:

Enfim (não fique admirado, mas todo tradutor tem sua cisma), gostaria de ter sua definição de "vereda"; com quase certeza, não vou traduzir a palavra para o italiano, aliás, procurarei introduzi-la na minha língua, como indicativa de uma realidade típica e intransponível, mas, justamente por isso, preciso ter confirmada a imagem que me formei daquela realidade. ${ }^{8}$

A resposta pormenorizada do escritor mineiro, datada de 11 de outubro de 1963, descreve a "paisagem geográfica", o ambiente de feições variadas, que caracteriza o sertão

\footnotetext{
${ }^{5}$ BIZZARRI, Edoardo. João Guimarães Rosa: Correspondência com seu Tradutor Italiano. $3^{\text {a }}$. ed. Rio de Janeiro: Nova Fronteira, 2006, p.100.

${ }^{6}$ Ibid., p. 110.

${ }^{7}$ Ibid., p. 37.

${ }^{8}$ Ibid., p. 36.
} 
dos "Gerais", assim como explica sobre o homem que o habita. Julgamos inevitável, por se

tratar da gênese do nosso trabalho, tomar a liberdade de transcrevê-la em inteiro teor:

\section{VEREDA}

Você sabe, desde grande parte de Minas Gerais (Oeste e sobretudo Nordeste), aparecem os "campos gerais", ou "gerais" - paisagem geográfica que se estende, pelo Oeste da Bahia, e Goiás (onde a palavra vira feminina: as gerais), até ao Piauí e ao Maranhão. O que caracteriza esses GERAIS são as chapadas (planaltos, amplas elevações de terreno, chatas, às vezes serras mais ou menos tabulares) e os chapadões (grandes, imensas chapadas, às vezes séries de chapadas). São de terra péssima, vários tipos sobrepostos de arenito, infértil. (Brasília é uma típica chapada...) E tão poroso, que, quando bate chuva, não se forma lama nem se vêem enxurradas, a água se infiltra, rápida, sem deixar vestígios, nem se vê, logo depois, que choveu. A vegetação é a do cerrado: arvorezinhas tortas, baixas, enfezadas (só persistem porque teem longuíssimas raízes verticais, pivotantes, que mergulham a incríveis profundidades). E o capim, ali, é áspero, de péssima qualidade, que, no reverdecer, no tempo- das - águas, crescem incrustados na areia, de partículas de sílica, como se fosse vidro moído: e adoece por isso, perigosamente, o gado que o come. Árvores, arbustos e má relva, são, nas chapadas, de um verde comum, feio, monótono.

Mas, por entre as chapadas, separando-as (ou, às vezes, mesmo no alto em depressões no meio das chapadas) há as veredas. São vales no chão argiloso ou turfo-argiloso, onde aflora a água absorvida. Nas veredas, há sempre o buriti. De longe, a gente avista os buritis, e já sabe: lá se encontra água. A vereda é um oásis. Em relação às chapadas, elas são, as veredas, de belo verde-claro, aprazível, macio. O capim é verdinho-claro, bom. As veredas são férteis. Cheias de animais, de pássaros.

As encostas que descem das chapadas para as veredas são em geral muito úmidas, pedregosas (de pedrinhas pequenas no molhado chão claro), porejando agüinhas: chamam-se resfriados. O resfriado só tem uma grama rasteira, é nítida a mudança de aspecto da chapada para o resfriado e do resfriado para a vereda. Em geral, as estradas, na região, preferem ou precisam de ir, por motivos óbvios, contornando as chapadas, pelos resfriados, de vereda em vereda. (Aí, talvez, a etimologia da designação: vereda.)

Há veredas grandes e pequenas, compridas ou largas. Veredas com uma lagoa; com um brejo ou com um pântano; com pântanos de onde se formam e vão escoando e crescendo as nascentes dos rios; com brejo grande, sujo, emaranhado de matagal (marimbú); com córrego, ribeirão ou riacho. (Por isso, também, em certas partes da região, passaram a chamar também de veredas os ribeirões, riachos e córregos - para aumentar a nossa confusão). (No começo do "Grande Sertão: Veredas" Riobaldo explica).

Em geral, os moradores dos "gerais" ocupam as veredas, onde podem plantar roça e criar bois. São os veredeiros. Outros, moram mesmo no alto das chapadas, perto das veredinhas ou veredas altas, que, como disse, também há, nas chapadas: estes são os "geralistas" propriamente ditos (com relação aos veredeiros, isto é, em oposição aos veredeiros). Mas o nome de geralista abrange, igualmente, a todos: os veredeiros e os geralistas propriamente ditos. Quem mora nos gerais, seja em vereda ou chapada, é geralista. Eu, por exemplo. Você, agora, também.

Nas veredas há às vezes grandes matas, comuns. Mas, o centro, o íntimo vivinho e colorido da vereda, é sempre ornado de buritis, biritiranas, safarrás e pindaíbas à beira da água. As veredas são sempre belas! ${ }^{9}$

\footnotetext{
${ }^{9}$ BIZARRI, Edoardo. João Guimarães Rosa: Correspondências com seu Tradutor Italiano. $3^{\mathrm{a}}$ ed. Rio de
} Janeiro: Nova Fronteira, 2006, p. 40-43. 
Como é possível observar, vereda é uma unidade lexical empregada como unidade nominal, em função locativa, por um grupo específico, o geralista do sertão dos Gerais. Os termos específicos, descritivos ou associativos que lhe são acrescentados projetam linguisticamente o ambiente geográfico e social, como podemos observar em Vereda-FrangoD’água, Vereda-da-Vaca-Mansa-de Santa Rita, Vereda do Vitorino, Vereda-do-Cocho, Veredas-Mortas,Veredas-Altas, Vereda do Buriti Pardo, Veredas-Quatro,Vereda-da-VacaPreta,Vereda do Alegre, Veredas Tortas, Vereda do Enxú,Vereda-Meã, Vereda do Saz, quer tenham sido esses termos capturados e transplantados para Grande Sertão: Veredas, quer sejam eles fruto da criatividade inventiva de Rosa, gerados a partir de dados da realidade.

Aqui nos confrontamos com nossa primeira questão. Como nos referir à palavra vereda neste universo de discurso? Trata-se de um vocábulo ou de um termo? Qual o estatuto da unidade lexical vereda, na obra de João Guimarães Rosa? Em que norma discursiva poderíamos inserir as palavras sertão, gerais, buriti, jagunço, dentre outras, considerando-se o universo de discurso da língua geral e o universo de discurso das linguagens de especialidades?

Ao analisarmos a questão pela primeira vez, para poder classificar a unidade lexical vereda, na indecisão, intuitivamente o problema se revelou. Algum tempo depois, tendo a oportunidade de ler o artigo "Etnoterminologia e Terminologia Aplicada: objeto de estudo, campo de atuação”, de Maria Aparecida Barbosa, vislumbramos outro caminho para a análise das denominações, tão caras a Rosa, partindo de uma perspectiva que nos pareceu mais apropriada.

Muito já sabemos sobre as características que nos permitem distinguir e delimitar o vocábulo da língua geral e o termo técnico-científico das linguagens de especialidades. Porém a peculiaridade da palavra vereda, e de tantas outras no universo linguístico-literário de Guimarães Rosa, é de grande relevância, pois essas palavras se tornaram "símbolos" reais do espaço geográfico e de sua percepção da natureza e dos conhecimentos culturalmente herdados. São palavras que participam de um universo de discurso tão particular que, ao se manifestarem em determinados discursos literários, fica claro que reúnem qualidades não apenas da linguagem literária, mas também das linguagens de especialidades. Pertencem a um grupo de falantes linguística e socialmente definido, histórica e geograficamente delimitado. Tais palavras congregam valores semânticos e conceptuais próprios de uma realidade, e exigem do leitor imersão total nesse grupo social, ao lado do homem que o habita.

Vivemos um momento em que a tendência generalizada é de proximidade cada vez maior em um mundo globalizado, aceitando-se novas regras de convivência que conduzem os 
vários grupos linguísticos a novas relações políticas, sociais, culturais, permeadas da identidade do outro. Isto impede que, nos tempos atuais, concentremo-nos em nossas raízes linguísticas e socioculturais, para refletirmos, principalmente com nossa juventude, sobre os autênticos aspectos da vasta realidade brasileira.

Constituir documentos do processo histórico e cultural é preservar o valor semântico e social, a despeito do caráter dinâmico da evolução social, cultural e linguística, que não se faz sem os movimentos de desaparecimento, conservação e surgimento de novas realidades. Sem esses movimentos é impossível ao homem considerar o outro e fazer-se entender pelo outro, seu interlocutor, a razão primeira dos atos linguísticos.

O debruçar constante sobre os documentos literários ou não, dos quais emergem os valores regionais que dão a conhecer a identidade dos nossos grupos sociais, é uma das atribuições de maior importância do pesquisador, como forma de resgate da identidade linguística regional em contraste à identidade linguística com forte tendência globalizadora.

Como identificar todos os traços semânticos, ou o valor conceptual exato de palavras como vereda ou veredeiro sem nos voltarmos para o "imo" de nossa língua e cultura, apesar de sermos também cidadãos do mundo?

Pretendemos, neste trabalho, empreender a análise do comportamento linguístico das denominações no léxico de Grande Sertão: Veredas, considerando a linguagem, conforme ensinou Saussure, um fato social ${ }^{10}$, um conjunto de unidades lexicais que caracterizam modelos sociais e culturais específicos do geralista dos sertões dos Gerais.

Examinaremos os traços de etnia e etnicidade, próprios de uma sociedade e do homem inseridos naquela paisagem geográfica, refletidos no semantismo dos vocábulos que utiliza.

A abordagem etnoterminológica do léxico de Grande Sertão: Veredas, procurará, portanto, encontrar as raízes da cultura que permeia a obra associada à herança popular cultivada no seio de um grupo social, interrelacionar língua e sistema de valores (social, linguístico e cultural), a geografia e o tempo de um dos muitos grupos sociais que desenham a nossa identidade, além de procurar contribuir para documentar e compreender analiticamente uma cultura única.

${ }^{10}$ SAUSSURE, Ferdinand de. Curso de Linguística Geral. São Paulo: Editora Cultrix, 1971. p.14. 
Essas unidades lexicais apresentam sememas construídos em grande parte, com semas específicos do universo de discurso etnoliterário, provenientes das narrativas e cristalizados de maneira a tornarem-se verdadeiros símbolos dos temas envolvidos. É preciso estar familiarizado com as histórias, conhecer o pensamento e o sistema de valores da cultura em questão, para poder compreendê-los bem. De fato, é outra linguagem, que é preciso aprender, para interpretá-los corretamente. ${ }^{11}$

Consideramos a importância dada pelo autor ao "altíssimo primado da intuição, da revelação, da inspiração, sobre o bruxulear presunçoso da inteligência reflexiva, da razão, a megera cartesiana"12, elementos fundamentais que estão em consonância com as características da cultura popular herdada. Situamo-nos, portanto, na vertente etnoliterária, ou, mais especificamente, nas particularidades das denominações, de grande importância para os sertanejos dos gerais e também para Rosa e que se apropriam do conteúdo etnoterminológico. Interessa-nos saber como tais conteúdos se sustentam, com quais características, e em que medida refletem a conceptualização de um grupo linguístico que constrói semioticamente a sua realidade.

Articularemos as seguintes variáveis: o sentido de etnia e etnicidade na formação sociocultural de um grupo; as interferências históricas e geográficas que subordinam o processo de conceptualização dos sujeitos que integram determinado grupo linguístico; as formas escolhidas para denominação, fruto do contato com a realidade e visão de mundo estabelecida de acordo com essa realidade, e a axiologia que permeia as relações sociais e culturais enquanto herança da cultura popular amealhada ao longo do tempo, registrando valores, usos, costumes, crenças, hábitos de caráter fundamental, porém abstratos, que modulam, enfim, a maneira de pensar, sentir e viver de um grupo.

Estabelecemos a hipótese de que as palavras, mesmo as de uso em língua geral, assumem significado específico na obra literária Grande Sertão: Veredas.

Esta hipótese direcionou nossas escolhas teóricas e metodológicas, cujo objetivo principal fixamos na análise do plano linguístico-conceptual e no sistema de valores subjacentes ao léxico da obra. Isto significa analisar em que medida a visão de mundo, a axiologia do sertanejo está condensada em palavras da língua geral portadoras de

\footnotetext{
${ }^{11}$ BARBOSA, Maria Aparecida. Etnoterminologia e Terminologia: Objeto de Estudo, Campos de Atuação. In: As ciências do Léxico. V. III. Mato Grosso do Sul: Associação Editorial Humanitas, Editora UFMS, 2007, p. 440 .

${ }^{12}$ BIZZARRI, Edoardo. João Guimarães Rosa: Correspondência com seu Tradutor Italiano. Rio de Janeiro: Nova Fronteira, 2006, p.12.
} 
multifuncionalidade, cuja dupla significação não está ao alcance da compreensão de quem não é o sertanejo de Rosa.

Definimos, em seguida, os objetivos específicos decorrentes: delimitação das unidades lexicais a serem estudadas; comparação entre o significado das palavras escolhidas em Rosa com o significado em dicionários de língua atuais e antigos; análise e descrição das palavras escolhidas com vistas à inferência do mundo semioticamente construído por Rosa, utilizando a ficha etnoterminológica elaborada especificamente para este fim; identificação, no universo lexical da obra escolhida, das estruturas semânticas e conceptuais do "vocábulo-termo" e a consequente caracterização da unidade padrão do domínio coberto pela Etnoterminologia.

De acordo com Cidmar Teodoro Pais, os sistemas de significação e os seus discursos, dialeticamente articulados, produzem significação na relação de dependência do plano de conteúdo e do plano de expressão a partir de recortes culturais engendrados no seio da vida social, produzindo e sustentando sua ideologia no tempo e nas relações com a cultura e sociedade. Examinaremos, portanto, os valores apreensíveis na articulação linguística interna de um grupo, com suas especificidades sociais e culturais, definíveis como modelo de ação e interação entre seus membros.

Ao considerarmos, com Guimarães Rosa, os valores que atribui ao "cenário $e$ realidade sertaneja: 1 ponto; enredo: 2 pontos; poesia: 3 pontos; valor metafísico-religioso: 4 pontos $" 13$, verificamos que o autor proclama o primado do valor metafísico-religioso, que sabemos é representado por um veículo de suma importância em sua obra: a linguagem.

Sabemos que toda pesquisa nos remete ao anterior, ao mais antigo, ao já esquecido, como elos de uma corrente que, encadeando conhecimentos, nos transmitem como herança as primeiras aprendizagens, fruto dos dados da observação objetiva da realidade e aqueles da observação subjetiva, não sendo possível produzir conhecimentos que de algum modo não façam parte de um processo pelo menos embrionário, gestado em algum momento em que o mundo ou o homem foi pensado, ou, conforme as palavras de Riobaldo: "A vida inventa! A gente principia as coisas, no não saber por que, e desde aí perde o poder de continuação porque a vida é mutirão de todos e por todos remexida e temperada." 14

Os estudos das ciências do léxico acumularam-se no mesmo ritmo acelerado das descobertas e inovações científicas, e imprimiram à Terminologia uma dinâmica paralela de estudos intensos voltados para os discursos das linguagens de especialidades. O processo de

\footnotetext{
${ }^{13}$ BIZZARRI, Edoardo. João Guimarães Rosa: Correspondências com seu tradutor italiano. $3^{\text {a }}$ ed. Rio de Janeiro: Nova Fronteira, 2003, p. 90, 91.

${ }^{14}$ ROSA, João Guimarães. Grande Sertão: Veredas. Rio de Janeiro: Nova Fronteira, 2006. p.461.
} 
investigação e estudo constante percebeu entre o vocábulo, a unidade padrão da língua geral, e o termo, a unidade padrão das linguagens de especialidades, uma unidade que não apenas incorpora os valores e as funções de vocábulo, mas simultaneamente os valores e funções de termo nos discursos etnoliterários. É esta unidade, o vocábulo-termo, o objeto da nossa análise.

O plano conceptual é a forma final do processo de atribuição e supressão de valores, funções e traços a partir da projeção do homem sobre os fatos da natureza e da sociedade que convergem para determinada visão de mundo. Conceber determinada realidade significa, para o homem ou para um grupo, tecer seu contexto sociocultural específico, cuja origem se desenvolve dinamicamente no tempo e no espaço.

É o processo de elaboração cultural que gera, por sua vez, o universo antropocultural, com seu sistema próprio de significações.

Embora todo grupo esteja sujeito a influências, o grau de resistência de um grupo específico às influências externas e sua união em torno das particularidades da sua realidade constitui sua identidade cultural. A herança cultural de um grupo é expressa pelos padrões populares tradicionais que se caracterizam enquanto sistema de valores, costumes e crenças.

Enfim, o olhar etnoterminológico lança luzes sobre o estudo do termo no discurso etnoliterário, que escapa à Terminologia no campo específico a que sua análise está circunscrita.

Naturalmente o produto da análise etnoterminológica resultará em aplicações de importância prática, como uma melhor compreensão da cultura de grupos idiossincráticos, organizados em um país de imensas proporções territoriais como o nosso. Poderá também servir como documento de estudo antropológico, como fonte de estudo do processo histórico e mítico, ou como instrumento de auxílio na tradução literária e de, particularmente, contribuir para o ensino da língua portuguesa.

Em síntese, na vertente etnoliterária das denominações dos sertanejos dos gerais e de Rosa, buscaremos saber como se sustentam seus conteúdos semânticos, com quais características, e em que medida refletem a conceptualização de um grupo linguístico que constrói semioticamente a sua realidade.

Com efeito, assim se estrutura nossa dissertação, além desta introdução: no capítulo, "O Universo da Pesquisa”, trataremos das circunstâncias históricas e do espaço geográfico em que se localizam os campos-gerais. O objetivo será o de desvelar os fatores condicionantes que repercutiram na redescoberta das palavras em sua fusão com os elementos do português antigo e os da modernidade, e na busca, pelo autor, do seu sentido original. Ainda nesse 
capítulo analisaremos, partindo de declarações do autor, sua visão da realidade, da sua própria literatura e do labor com a palavra enquanto ofício enfrentado como arte comparada à cinematografia. Finalmente, examinaremos o papel reservado ao substrato popular num diálogo com o continuum herdado, filiando Grande Sertão a uma solução culta proveniente de raízes intencionalmente fincadas na cultura popular, resumida na máxima riobaldiana, em que tudo é e não é, em seus limites entre o velho e o novo.

No capítulo seguinte trataremos do processo semiótico do discurso e suas relações entre universos de discurso, a partir do duplo processo da enunciação de codificação e de decodificação, bem como o texto enunciado, produto do processo semiótico, nele incluídas as modalizações discursivas que se dará sob a ótica dos pressupostos teóricos de Cidmar Teodoro Pais, cuja visão sustenta-se na dialética do discurso entre consenso e especificidade, na interação das estruturas linguísticas, sociais e culturais, que em dinâmica inexaurível tem como produto a criação de novas formas de representação da realidade.

Os subsídios teóricos da Etnoterminologia, construídos por Maria Aparecida Barbosa, são aspectos que investigaremos ainda nesse capítulo: as fronteiras da Etnoterminologia e as ciências da linguagem; as modalizações discursivas; os aspectos sociolinguísticos da gênese do vocábulo-termo na Etnoterminologia; a caracterização do vocábulo-termo e, finalmente, o aspecto de fundamental importância: a formação do conceito, no discurso etnoliterário rosiano.

A Etnoterminologia considera os contornos do vocábulo na linguagem etnoliterária e sua intersecção com o termo enquanto unidade terminológica das linguagens de especialidades, até o ponto da sua ruptura funcional e semântica como vocábulo e como termo, ao subsumir ambas as funções e significações no texto etnoliterário.

Descrevemos, então, o corpus documental, um extenso monólogo, em que Riobaldo dialoga com um interlocutor que interage pouco, e traz à tona sagas vividas no sertão. As palavras-chave extraídas do romance de Rosa com o auxílio do programa Wordsmith Tools foram submetidas a agrupamento por zonas arritmo-semânticas no último capítulo, foram analisadas em fichas etnoterminológicas especialmente elaboradas para demonstrarmos a formação semântico-conceitual dos vocábulos-termos. Finalmente, procedemos à análise das fichas etnoterminológicas e sua sistematização, e elaboração das conclusões finais.

No livro Corpo de Baile, apareceu pela primeira vez a palavra vereda, objeto de dúvida de Edoardo Bizarri, o tradutor italiano de Rosa. O tradutor não sabia se havia construído a correta imagem da realidade que deveria transplantar para sua língua, e sua indagação a Rosa originou nossas primeiras reflexões, que se transformaram em nossa 
Dissertação de Mestrado. Sem dúvida alguma, um presente a nós concedido, nessa nossa travessia. 


\section{O UNIVERSO DA PESQUISA}

O tempo infinitamente se conjuga ao espaço para tecer as singularidades das nações e dos povos que as habitam, e a História, em seus movimentos, se projeta no ambiente social, na paisagem e na língua, definindo o futuro do Homem. Nas páginas seguintes poderemos verificar os vários elementos que concorreram para caracterizar um grupo distinto de tantos outros que contribuem para a diversidade cultural do nosso país. A recomposição dos fatos e fenômenos, ao abrigo da língua, dado observável, que simultaneamente exerce o papel duplo de artífice e espelho da realidade, revela o etnismo das práticas sociais, do fazer cultural e a importância exercida pelo isolamento na paisagem geográfica. São elementos que se somaram à percepção de um homem que soube, a partir da análise da experiência humana, em um canto escondido de Minas, registrar, com palavras escritas, a concepção desse mundo particular.

\subsection{Elementos históricos e geográficos na constituição do Estado de Minas Gerais}

A procedência da língua clássico-arcaica que encantava o escritor mineiro e a explicação para sua sobrevivência até o tempo e o lugar em que Rosa nasceu estão presentes não apenas em fatos da história, como também na localização do seu estado. Trataremos dos fatores essenciais que constituíram uma comunidade de língua, com características especiais, fundadas no vínculo social a que Saussure chamou de etnismo, assunto que aprofundaremos mais à frente.

A essência das descrições que valorizam a obra rosiana é enriquecida com topônimos e antropônimos que cobrem amplamente a taxionomia de Dick $^{15}$, e tem sua gênese na cultura popular herdada. Para entendermos a manutenção dessa herança no seio da vida social de uma comunidade linguística precisamos investigar a origem dessa cultura.

No período da colonização, o Brasil Central foi tido, por muitos e muitos anos, como inatingível, visto o grande número de expedições que partiam para o interior do país e não

\footnotetext{
${ }^{15}$ DICK, Maria Vicentina de P. do A. Toponímia e antroponímia no Brasil: coletânea de estudos. São Paulo: FFLCH/USP, 1986.
} 
regressavam. Vários eram os impedimentos, como a densa floresta, animais ferozes, índios antropófagos e falta de alimentos para a sobrevivência dos exploradores.

A primeira expedição oficial em busca do ouro, que os espanhóis, rivais dos portugueses, retiravam fartamente das terras que lhes pertenciam, do lado ocidental do Brasil, às centenas de quilos anuais, foi organizada por Tomé de Souza, em 1550, e dela nunca mais se teve notícias.

O paulista Fernão Dias foi o primeiro desbravador a conseguir sucesso, e foi o responsável por abrir o caminho que hoje nos leva de São Paulo a Minas Gerais, conseguindo chegar ao local hoje conhecido por Sabará que, dizia a lenda, tinha uma montanha de ouro, rodeada por um lago, igualmente de ouro, que os nativos denominavam Sabarauçu.

Sua expedição diferenciou-se das anteriores pois, ao longo dos dez anos que levou para empreender sua missão, Fernão Dias enviava comandados que preparavam o caminho para sua expedição, com a plantação de lavouras e criação de animais.

A primeira vanguarda para esse fim, comandada por Matias Cardoso, partiu por volta de 1670. Vários autores são unânimes em afirmar que Matias Cardoso estabeleceu-se realmente na região. Fundou com seu grupo alguns arraiais e algumas fazendas, dentre os quais o Arraial do Meio. Por força de enchentes, seu grupo mudou-se para as margens do rio São Francisco, ali erguendo o povoado de Morrinhos, hoje cidade de Mathias Cardoso, conforme registra Almeida Costa.

A Província de Minas Gerais, criada no ano de 1720, para conter as informações sobre a fartura de ouro, era até então uma porção de São Paulo. A agricultura serviu de suporte para que os mineiros, os trabalhadores que extraíam ouro e pedras preciosas daquelas terras, sobrevivessem.

O paulista, geralmente português à procura e na exploração do ouro, aparece como determinante no povoamento do interior de Minas Gerais, no sentido sul-norte, com característica principal de mobilidade. Contrapondo-se à figura do explorador insaciável, encontramos os geralistas do sertão dos Gerais, vindos da Bahia, no sentido norte-sul, que por sua vez fixava-se à terra. Ambos, mineiros e geralistas, protagonizaram duas realidades sociais distintas.

A dedicação à atividade pastoril, que se realizou também nos campos gerais, deu origem a diversas povoações às margens e vales do rio São Francisco.

Os descendentes de portugueses, naturalmente, formavam a maioria da população no começo do desbravamento. No entanto, de outras regiões da Europa também afluíram exploradores e naturalistas, estes pagos por seus países, por mais que Portugal tentasse manter 
o insulamento da região, necessário para o sigilo dos conhecimentos e informações sobre as terras ultramarinas das minas de ouro.

São, portanto, os portugueses de São Paulo, como são chamados os paulistas pelos espanhóis, muitas vezes mestiços de índios com características étnicas e culturais do índio, que estariam na origem étnica do povo mineiro ${ }^{16}$.

Além dos portugueses, a outra contribuição para a miscigenação do mineiro foi trazida pelos africanos vindos de Angola, como escravos, para trabalharem nas minas de ouro. Os escravos passaram a constituir a maioria da população no século XVII, e o mulato desde cedo passou a integrá-la como fruto da união entre portugueses e mães negras ou mestiças.

Temos assim, como importante dado a nos esclarecer a origem multicultural do centro do Estado de Minas, a procedência dos povos que vieram habitar as regiões das minas de ouro: o índio preado que auxiliava os portugueses nas expedições, o colono da Europa, sobretudo de Portugal, que afluía à região procurando melhores condições de vida, e os negros trazidos de Angola como escravos. O outro fator de suma importância, como já apontamos, foi a condição de isolamento imposta desde cedo pela Metrópole, com medo de que o ouro não chegasse às mãos da Coroa.

Durante o século em que a descoberta de ouro foi mais ativa, a população europeia cresceu em Minas dez vezes, e proporcionou o desenvolvimento demográfico do interior do país, apartado que era da costa litorânea, uma vez que os portugueses eram, por tradição, afeitos à colonização costeira.

A procura do ouro e sua exploração proporcionaram, em um século, grande riqueza e geraram oportunidades aos estudantes que anualmente foram enviados à Europa aos seus cursos universitários. Minas Gerais projetou-se em condição dominante no panorama nacional em relação às manifestações culturais e artísticas. ${ }^{17}$

Em sua viagem feita pelo Brasil entre 1817 e 1820, os naturalistas Martius e Spix registram que, de acordo com a avaliação da época, havia em toda Minas Gerais cerca de meio milhão de habitantes, sendo que em Vila Rica, a capital da província, cerca de 8500 , entre portugueses, europeus e principalmente muitos mulatos e negros. ${ }^{18}$ Trata-se de uma informação corroborada por Matos: a população não era maior do que 500 mil pessoas e a

\footnotetext{
${ }^{16}$ MATOS, Raimundo José da Cunha. Corografia Histórica das Minas Gerais. Belo Horizonte: Livraria Itatiaia Editora Limitada, 1981, p.19.

${ }^{17}$ HOLANDA, Sergio Buarque de (org.) . História da Civilização Brasileira: A Época Colonial. Tomo I, $2^{\circ}$ v. $7^{\mathrm{a}}$ ed. Rio de Janeiro: Bertrand Brasil, 1993, p. 310.

${ }^{18}$ SPIX e MARTIUS. Viagem pelo Brasil. Tomo I, 1817-1820. 2a . ed., Editora São Paulo: Melhoramentos, 1959 , p. 208.
} 
metade, constituída por escravos mulatos livres ou privados de liberdade, negros livres ou escravos e poucos brancos. ${ }^{19}$

Ainda em sua passagem por Minas, Martius e Spix registraram que as mais diversas manufaturas animavam o comércio local, que era o mais movimentado entre o de todas as cidades do Brasil e abastecia-se inclusive com mercadorias europeias vindas do Rio de Janeiro. As ruas das cidades que ainda se encontravam na pujança da extração do ouro eram calçadas, as igrejas imponentes, pintadas por artistas nacionais, e com lojas nas quais se encontravam artigos de luxo da Europa, particularmente de Portugal e da Inglaterra. ${ }^{20}$

Martius e Spix observaram a flora e descreveram os usos do buriti, tão abundante quanto útil, pois fornece aos

\begin{abstract}
habitantes fios e fibras resistentes, retiradas da epiderme das folhas; com estas, dá coberta para palhoças; fazem-se gradeados e ripas, com a parte periférica de seu caule; remos, com a haste de suas folhas; uma bebida muito agradável, semelhante a água de bétula e suscetível de fermentação alcoólica, com a seiva contida no caule;e um saboroso petisco é preparado com a polpa do fruto, misturando com açúcar, que , com o nome de saieta, é doce apreciado e artigo de comércio do sertão de minas com a costa. Todas estas utilidades tornaram quase sagrada para os sertanejos a preciosa árvore e, nalgumas regiões, como por exemplo, em São Romão, é costume dar-se em dote à filha também um certo número de buritis. ${ }^{21}$
\end{abstract}

Teodoro Sampaio, em 1877, registra em suas cadernetas da expedição que fazia desde a foz do rio São Francisco até Minas Gerais, a paisagem de alguma forma diferenciada:

Entramos numa região eminentemente calcária, região que parece estende-se por larga zona do território mineiro, indo de um lado entestar com a serra do Espinhaço e do outro lado até Goiás, na cordilheira que os nossos geógrafos denominaram das Vertentes. É a região pitoresca das cavernas, dos sumidouros, das grutas de estalactites, das torres e dos bastiões erguidos no cimo dos araxás e que são o encanto dos viajantes do sertão. ${ }^{22}$

\footnotetext{
${ }^{19}$ MATOS, Raimundo José da Cunha. Corografia Histórica das Minas Gerais. Belo Horizonte: Livraria Itatiaia Editora Limitada, 1981, p.68.

${ }^{20}$ SPIX e MARTIUS. Viagem pelo Brasil. Tomo I, 1817-1820. $2^{\mathrm{a}}$., São Paulo: Melhoramentos, 1959, p.208.

${ }^{21}$ Ibid., p.168.
}

${ }^{22}$ SAMPAIO, Teodoro. O Rio São Francisco e a Chapada Diamantina, org. José Carlos Barreto de Santana. São Paulo: Companhia das Letras, 2002, p.152. 
Seguindo pela região sueste, pelo São Francisco, o vale do rio das Velhas, também descreve os pés de buritis e as veredas, que mais tarde Rosa viria a imortalizar:

\begin{abstract}
O terreno coberto de gramíneas altas, e sombreado de árvores raras, dispersas, deixanos bem patente o dorso, levemente ondeado, da chapada, em cujas dobras úmidas cresce copado e vigoroso o buriti, orlando de verde os brejais, acompanhando com uma aléia de floras de palmas esféricas o curso dos ribeiros minúsculos que deslizam pelas encostas e vão engolfar-se nas planícies lá embaixo. ${ }^{23}$
\end{abstract}

Os exploradores das minas de ouro e pedras preciosas e os vaqueiros, criadores de gado do sertão e dedicados à atividade pastoril, atuaram cada grupo em áreas diferentes e cada um desempenhando atividades também distintas. Nos primórdios da colonização, a designação de geralista era atribuída aos moradores da Capitania de São Paulo e Minas do Ouro, depois denominada Capitania de Minas Gerais e, só mais tarde, seriam chamados mineiros. Falarmos do sertão dos gerais significa seguir passo a passo as pegadas do explorador ou do bandeirante paulista em sua marcha na expansão do nosso território.

São duas mentalidades absolutamente diversas, duas formações históricas diferentes, duas áreas geográficas. Há um contraste entre as minas e os gerais.

Os criadores de gado da região do norte de Minas, dos gerais, com sua agricultura de subsistência, deram oportunidade aos mineiros de sobreviver em uma região inóspita, já que estes eram dependentes de alimentos, gado e animais de transporte para poderem exercer sem interrupção a exploração de ouro.

Ao se referir ao nome do estado, os mineiros da atualidade fazem referência ao amplo espaço das minas, que se espraiavam ao longo da serra do Espinhaço, em extensa área: as minas gerais. Existem, porém, os gerais, campos que se distribuem por grande parte do território brasileiro, e que fazem parte da geografia do sertão de Minas. Falar das minas ou dos gerais como sendo a mesma realidade social em um mesmo espaço é erro comum entre os mineiros, embora ambas as sociedades tenham contribuído para a consolidação da história e sociedade mineiras.

Os campos gerais ou os gerais se estendem pelo interior do norte de Minas, oeste da Bahia e Goiás, onde a palavra vira feminina, até o Piauí e Maranhão e onde encontramos o geralista e o veredeiro como já nos ensinou Rosa.

\footnotetext{
${ }^{23}$ SAMPAIO, Teodoro. O Rio São Francisco e a Chapada Diamantina, org. José Carlos Barreto de Santana. São Paulo: Companhia das Letras, 2002, p.184,185.
} 


\subsubsection{Cordisburgo, a cidade natal}

Matos identifica em um mapa topográfico do início da segunda década de 1800 "o arraial ou grande fazenda do Jaguara, na margem esquerda do rio das Velhas", pertencia à freguesia de Matosinhos, arraial situado na margem esquerda do rio das Velhas. ${ }^{24}$

De fato, a sesmaria Empoeiras pertencia à região do extinto vínculo do Jaguara, local ao qual o padre João de Santo Antônio chegou em meados do ano de 1883, denominando-o "Vista Alegre", por se tratar de lugar com paisagens exuberantes e clima agradável. Para estabelecer-se e fundar o povoado precisava de sua posse, que obteve com a influência de Dona Policena Mascarenhas, que vendo a sesmaria ir a leilão, mandou seu filho arrematá-la em nome do Irmão João, cedendo 40 alqueires como patrimônio da igreja.

A fundação do povoado deu-se no dia 21 de agosto de 1883, com a edificação da capela ao patriarca São José, tendo sido concluída em 23 de junho de 1884.

A ideia da construção de um templo surgiu quando o padre João mandou vir da França uma imagem do Coração de Jesus. Em 08 de março foi levantada a primeira linha do templo no Arraial de Vista Alegre e o padre João começou a distribuir terrenos gratuitamente para que as pessoas construíssem suas casas. $\mathrm{O}$ arraial de Vista Alegre começava a ser povoado.

Não demorou muito, e em 09 de junho de 1890, João Pinheiro da Silva, então governador de Minas, elevou o povoado de Coração de Jesus de Vista Alegre a distrito de Cordisburgo de Vista Alegre, município de Sete Lagoas. Cordisburgo situa-se, como Rosa registrou em sua carta a Bizzarri, "isolado no imo de um estado central”, Minas Gerais, porta de entrada para o sertão mais "escuro", "ocultado demais".

Antonio Paiva de Moura explica que, com o declínio da exploração aurífera, e as perseguições aos habitantes das cidades em seu entorno, com confisco de bens e humilhações públicas, punições aos inconfidentes com degredos, confinamentos e penas de morte, os mineradores, clérigos e escravos procuraram as regiões desabitadas de Minas. O território se ampliou, transformando-se em agropecuaristas os que partiram, abrindo currais, fazendas e pequenos negócios. Começaram a erigir capelas e a criar freguesias ou vilas.

Os antigos mineiros, agora dedicados à criação de gado, dão origem à fundação dos municípios de São Romão, em 1831, e de Januária, em 1833, o qual se subdividiu em Manga e Itacarambi, e à fundação dos municípios de João Pinheiro, em 1837, e de Unaí, em 1850,

\footnotetext{
${ }^{24}$ MATOS, Raimundo José da Cunha. Corografia Histórica das Minas Gerais. Belo Horizonte: Livraria Itatiaia Editora Limitada, 1981, p.165.
} 
que mais tarde se desdobraria em Buritis e Bonfinópolis, dando à região em seu sentido norte sua configuração toponímica.

As conhecidas lutas pela hegemonia política da região Nordeste, com o contrato de jagunços pelos fazendeiros ou coronéis, para manter privilégios como benfeitorias públicas em suas propriedades, têm sua origem remota no começo do século XIX, no segundo império. Paulistas e mineiros se rebelaram contra as leis regressistas de Dom Pedro II que começava a governar, na condição de maioridade, sob a influência de um Conselho de Ministros de caráter conservador.

A revolta de 1842 insurgiu-se contra a centralização de poder exercida por D. Pedro II: excesso de impostos, confiscos, nomeações, pelo imperador, dos presidentes das províncias, de homens desconhecedores da região para a qual eram nomeados.

A hegemonia das oligarquias deu origem ao Coronelismo, e, no império, esclarece Moura:

havia os títulos nobiliárquicos e condecorações que premiavam serviços e também a Guarda Nacional para contentar a vaidade dos grandes senhores rurais, a República, que suprimia os títulos e as condecorações, teve que usar com mais liberdade as patentes da Guarda Nacional para premiar serviços políticos. ${ }^{25}$

Entre 25/12/1879 e 30/11/1880 Teodoro Sampaio atravessou a chapada Diamantina com destino até Carinhanha, na Bahia. Assim ele descreveu os desfeitos do bando do Neco:

\begin{abstract}
Chegamos à Januária cerca de quatro horas da tarde e desembarcamos logo. Reinava na cidade um lúgubre silencio. Era grande o terror entre os raros moradores que tinham permanecido e que, assustados, nos olhavam com desconfiança e se ocultavam logo. As ruas estavam desertas, as casas fechadas, o comércio recolhido, as autoridades fugitivas. Reinava o desânimo e o abandono era completo. ${ }^{26}$
\end{abstract}

Entre as cidades de Carinhanha e Januária, em Minas Gerais, Sampaio presenciou as lutas tão comuns entre as facções políticas rivais, que usavam da força, na contratação de

\footnotetext{
${ }^{25}$ MOURA, Antonio de Paiva. A Formação Histórica do Noroeste Mineiro. Disponível em: <www. asminasgerais.com.br/índex.asp?item=CONTEUDO \&codConteudoRaiz=92>. p.02. Acesso em: 17 de ago. 2010 .

${ }^{26}$ SAMPAIO, Teodoro. O Rio São Francisco e a Chapada Diamantina, org. José Carlos Barreto de Santana. São Paulo: Companhia das Letras, 2002, p.152,153.
} 
jagunços, ataques surpresa, invasões e pilhagens. Encontrou as autoridades do lugar amedrontadas, escondidas em lugares pobres (juiz, vigário, tabelião, policiais), e os habitantes defendendo-se atrás de barricadas construídas de grandes traves, pedras e areia. ${ }^{27}$

Ainda relata Matos que, no início do século XX, um episódio famoso às margens do Urucuia teve como protagonista o migrante baiano Antônio Dó. Naquela época os fazendeiros dividiam-se em facções rivais, das quais uma delas era vinculada ao PRM, que contratava o bandido para assassinar outros fazendeiros. O bando de Antônio Dó cresceu poderosamente, enfrentando os batalhões da Polícia Militar de Minas.

Nessa época estudando em Belo Horizonte, Rosa toma conhecimento das disputas através do tio e amigos cujos pais estavam diretamente envolvidos.

Mais uma vez os acontecimentos históricos enriqueceriam o imaginário do escritor, e ecoariam no palco geográfico das chapadas, chapadões e veredas aliados aos elementos que a criatividade de Rosa disporia nas diversas estórias que escreveu (assim grafaremos doravante estória, como era hábito do escritor).

"O homem do sertão", como se considerava, reuniu em si com plena consciência, o mundo místico do solo sertanejo, sua origem portuguesa voltada para o "remoto e estranho", suas experiências como médico, soldado e rebelde, seu mundo diplomático, o trato com cavalos, bois e vacas, religiões e idiomas, que o aproximaram do sofrimento, da proximidade da morte, do valor da consciência. ${ }^{28}$

\footnotetext{
${ }^{27}$ MATOS, Raimundo José da Cunha. Corografia Histórica das Minas Gerais. Belo Horizonte: Livraria Itatiaia Editora Limitada, 1981, p.153.

${ }^{28}$ Grandes entrevistas, Guimarães Rosa 2. Disponível em:

< HTTP://www.tirodeletra.com.br/entrevistas/GuimarãesRosa-1965.htm>, p.4. Acesso em: 9 de jun. 2011.
} 
2.2 Guimarães Rosa: o homem, o autor e a linguagem

Disse Rosa: "O caráter do homem é seu estilo, sua linguagem"29 "Linguagem e vida são uma coisa só "30. Dessa forma, não poderíamos tratar dos três aspectos deste título de maneira estanque. Propomo-nos, portanto, nas páginas seguintes, mais do que apresentar a biografia de Guimarães Rosa, fazer um levantamento das particularidades da vida e da personalidade que expliquem em alguma medida os mistérios e a opulência da linguagem que tantas atenções já atraíram.

Primeiramente, é necessário frisar que qualquer assunto ou autor que se refiram a Guimarães Rosa sempre o fazem em palavras portentosas, das quais também não conseguimos nos esquivar.

Os relatos de parentes, amigos, pesquisadores e, sobretudo, sua correspondência com seus tradutores estrangeiros apaixonadamente nos revelam seu amor pela língua, sua impaciente procura pela perfeição e o esforço que se exigia à procura do conhecimento feito de observação incessante e muita pesquisa.

A antropóloga e roteirista Ana Luiza Martins Costa, autora do artigo "Veredas de Viator", nos oferece também uma pesquisa monumental que documenta ano a ano a vida do homem e do autor, à qual são acrescentadas imensas notas bibliográficas, que em boa parte nos nortearam no presente estudo.

Um homem do sertão, como se considerava, João Guimarães Rosa nasceu em 27 de junho de 1908 em Minas Gerais, na cidade de Cordisburgo, onde também está localizada a gruta de Maquiné. Aflora, já na infância, seu interesse incomum pelas línguas e pela literatura e sobre geografia, botânica e zoologia que descreveria, mais tarde, minuciosamente em suas obras. $^{31}$

A palavra hipnotizava o homem. Desde criança as estórias contadas entre adultos atraiam sua atenção. Quem sabe já não sonhasse as palavras originais em seus brinquedos, no chão, entre as cenas de relevo que nele desenhava do curso de rios (que podia ser o Danúbio, o São Francisco, ou o Sapakral-lal, nome por ele inventado), com pedrinhas às suas margens

\footnotetext{
${ }^{29}$ Grandes entrevistas, Guimarães Rosa 2. Disponível em: <HTTP://www.tirodeletra.com.br/entrevistas/GuimarãesRosa-1965.htm> Acesso em: 09 de jun. 2011, p.13.

${ }^{30}$ Ibid, p. 15 .

${ }^{31}$ DANIEL, M.L. João Guimarães Rosa. In: Travessia Literária. Rio de Janeiro: Livraria José Olímpio, 1968, p. 4,5 .
} 
imitando cidades, ou construindo pontes de pauzinhos para que formigas passassem, e juntas de bois feitos de sabugo de milho. Quando um pouco mais velho, longe dos olhos dos adultos, em seu quarto, dava continuidade a outros sonhos, transformando em personagens as pessoas que desfilavam em seu cotidiano, enredando-as nas tramas para onde sua imaginação o levasse. $^{32}$

Cordisburgo, o burgo do coração, outrora Vista Alegre, era em seu tempo lugar de lindas paisagens, rodeada de montanhas, e as fazendas de gado da região proporcionavam à cidade um movimento contínuo de boiadas que embarcavam na pequena estação da estrada de ferro com destino a Belo Horizonte e a São Paulo.

A venda do seu pai, seu Fulô, próxima à estação, era o ponto de encontro dos vaqueiros, fazendeiros, mascates, garimpeiros, caçadores. Sua atenção frequentemente se desviava dos brinquedos para ouvir as estórias ali narradas.

Do sertão em que nasceu, o autor imprimiria em sua memória as cores da paisagem que suas personagens mais tarde percorreriam, e também as estórias que viveriam, as palavras que falariam e as características que as descreveriam. De fato revelou: "Todos os meus personagens existem. São criaturas de Minas: jagunços, vaqueiros, fazendeiros, pactários de Deus e do Diabo, meninos pobres, mulheres belas, moradores do Urucuia e redondezas."33

Destaca Walnice Nogueira Galvão que Rosa escrevia a seu pai com frequência, solicitando-lhe novas estórias do lugar, ou confirmação das antigas em pormenores, descrições dos fregueses da venda em Cordisburgo, para colecionar, assim, elementos para suas obras. Ou seja, ia colecionando, desse outro modo, a visão do sertanejo, a cultura e valores que norteavam sua vida naquela sociedade. Solicitava que deveria:

[...] ir se recordando e alinhando lembranças interessantes das coisas vistas e ouvidas na roça - caçadas, etc. - que possam servir de elementos para outro livro, que vou preparar, ou "mas o que mais me interessa é a estória do Juca Ferreira, aquele que vinha fazendo festas, com a viola, pelo rio das Velhas, até Pirapema"... "Uma expressão, cantiga ou frase, legítima, original, com a força da verdade e autenticidade, que vêm da origem, é como uma pedrinha de ouro, com valor enorme." 34

\footnotetext{
32 “Guimarães Rosa por ele mesmo: O escritor no meio do redemunho" In: Cadernos de Literatura Brasileira: João Guimarães Rosa. Instituto Moreira Salles, São Paulo, 2006, p.78

${ }^{33}$ Ibid., p.79

${ }^{34}$ GALVÃO, Walnice Nogueira. Rapsodo do Sertão: da lexicogênise à mitopoese. In: Cadernos de Literatura Brasileira. São Paulo: Instituto Moreira Salles, 2006, p.192
} 
A especial atração que sentia pelas diferentes línguas levou-o, na infância, a aprender francês e holandês. A inclinação pelo alemão, também precoce, instigou-o a querer estudar medicina em livros alemães, e conta-nos Eduardo Carvalho Tess, seu enteado, que teria namorado uma moça russa apenas pelo interesse que lhe despertava a língua por ela falada. Também em relação ao seu interesse pela leitura e amor pelo estudo, lembra-se Tess que, em seu tempo, ao cursar a faculdade de Direito, Rosa aconselhava-o a utilizar a mesma estratégia da qual na mocidade fazia uso: mergulhar os pés na bacia de água gelada, para assim, desperto, poder estudar até altas horas.

Acabada a faculdade de Medicina, durante cerca de três anos Rosa dedicou-se à profissão em Itaguará, e teve a oportunidade de voltar à convivência com o sertanejo da sua infância e de acumular outras memórias que também comporiam parte de sua obra.

Entretanto, "o gosto de estudar línguas, e a ânsia de viajar mundo", conforme registrou na correspondência ao seu tradutor italiano, levaram-no a prestar concurso para o Itamaraty em 1934, e a ser aprovado em $2^{\circ}$ lugar, como resultado de estudo árduo e determinação: "Só posso agir satisfeito no terreno das teorias dos textos, do raciocínio puro, dos subjetivismos. Sou um jogador de xadrez - nunca pude, por exemplo, com o bilhar ou o futebol", confidencia também em carta ao seu amigo Pedro Barbosa. ${ }^{35}$

Sentia o uso impróprio que se fazia das palavras e a deformação que sofriam em razão do desconhecimento da expressão correta, dotada da significação precisa revelada em cada um dos seus traços semânticos. Tal qual o garimpeiro que de sua bateia espera da areia enlameada ver surgir a pepita reluzente, Rosa também garimpava na língua a palavra em seu sentido mais oculto e preciso, selecionando palavras eruditas e do idioma clássico-arcaico que aprendera na infância, mas recorrendo também a palavras populares, a regionalismos, a brasileirismos ou a empréstimos:

\footnotetext{
${ }^{35}$ COSTA, Ana Luiza Martins. Veredas de Viator. In: Cadernos de Literatura Brasileira, João Guimarães Rosa. São Paulo: Instituto Moreira Salles, 2006, p.14.
} 
Eu incluo em minha dicção certas particularidades dialéticas da minha região, que são linguagens literárias e ainda têm sua marca original, que não estão desgastadas e quase sempre são de uma grande sabedoria linguística. Além disso, como autor do século XX, devo me ocupar do idioma formado sob a influência das ciências modernas e que representa uma espécie de dialeto. E também está à minha disposição esse magnífico idioma já quase esquecido: o português dos sábios e dos poetas daquela época dos escolásticos da Idade Média, tal como se falava, por exemplo em Coimbra.(...) Assim nasce então meu idioma que, quero deixar bem claro, está fundido com elementos que não são de minha propriedade particular, que são acessíveis igualmente para todos os outros. ${ }^{36}$

Observamos ademais, pelo relato acima, que tinha consciência da constante evolução linguística e da importância das ciências modernas que constituiriam as linguagens terminológicas próprias a cada área e que não poderiam ser ignoradas.

Leonardo Arroyo, defendendo a tese da gênese da linguagem rosiana com nítida colaboração da cultura popular, apoia-se no depoimento a Günter Lorenz no qual Rosa confessa os dotes à efabulação, próprios aos sertanejos: "desde pequenos, estamos constantemente escutando as narrativas multicoloridas dos velhos, os contos e lendas" que não deixaram suas estórias escritas, tendo mais tarde, deliberadamente, passado a escrevêlas, em literatura na forma de contos, lendas e confissões ${ }^{37}$.

Do mesmo depoimento a Günter Lorenz, Arroyo listou os elementos importantes da língua que utilizava:

1) considerava a língua como seu elemento metafísico, o que provocava uma série de consequências; 2) a existência de ilimitadas singularidades filológicas das variantes latino-americanas do português e do espanhol, nas quais existem fundamentalmente muitos processos de origem metafísica, muitas coisas irracionais, muito que não se pode compreender com a razão pura; 3 ) escala brasileira de expressões mais vasta que as existentes no português; 4) certas particularidades dialéticas da região mineira "que não são linguagem literária e ainda têm sua marca original, não estão desgastadas e quase sempre são de uma grande sabedoria linguística"; 5) interesse em ocupar-se do idioma formado sob a influência das ciências modernas e que representa uma espécie de dialeto; 6) o antigo português dos sábios e dos poetas " daquela época e dos escolásticos da Idade Média, tal como se falava por exemplo, em Coimbra" ${ }^{38}$.

\footnotetext{
36 “ Guimarães Rosa por ele mesmo: O escritor no meio do redemunho" In: Cadernos de Literatura Brasileira: João Guimarães Rosa. Instituto Moreira Salles, São Paulo, 2006, p.82, 83.

${ }^{37}$ ARROYO, Leonardo. Cultura Popular em Grande Sertão:Veredas. Rio de Janeiro, Livraria José Olímpio", 1984, p.19.

${ }^{38}$ Ibid., p. 20.
} 
Porém, não é apenas nos limites lexicais que a busca da perfeição e da originalidade transparece: as potencialidades da língua são desafiadas por Rosa com construções complexas, repletas de inversões e elipses, com o descaso a regras gramaticais rígidas, com acréscimo de sufixos e radicais que surpreendem o leitor e atestam sua imaginação criativa.

Rosa, escritor-pesquisador de rara sensibilidade, emoldurou, no sertão que lhe era tão caro, personagens e estórias que se enriqueceram com palavras mineiradas no passado distante e na realidade, ao captá-las no momento exato da sua produção. Representa os fatos no momento em que acontecem, utilizando a linguagem real de uso :

\begin{abstract}
Eu procuro captar o fato, o momento - como no cinema! -, para colocar o leitor dentro da trama. O leitor precisa conviver com os personagens. Mas, para captar este momento é preciso que o autor esteja no momento. Por isso eu tenho meus caderninhos que me acompanham em todas minhas viagens. Eu amarro um lápis com duas pontas e, no sertão, até em cima do cavalo eu escrevo. É o momento. ${ }^{39}$
\end{abstract}

Ou palavras que foram longamente amadurecidas para serem bem mais compreendidas e sentidas no seu vigor metafísico:

[...] a escrita para ele era uma gestação e um parto, era um esforço violento. Ele tinha que parar muitas vezes, e deixar guardada na gaveta, uma folha que ele tinha começado. E, às vezes, ele tirava, tentava recomeçar a trabalhar, não conseguia, guardava de novo. Então tem coisas dele, tem folhas começadas assim, que nunca foram acabadas, porque era difícil, porque ele procurava a palavra exata para aquilo que ele queria dizer. ${ }^{40}$

Ou, então, palavras inventadas, quando delas sentia falta para poder se expressar:

\footnotetext{
${ }^{39}$ ARROYO, Leonardo. Cultura Popular em Grande Sertão:Veredas. Rio de Janeiro, Livraria José Olímpio Editora,1984, p.84.

${ }^{40}$ COSTA, Ana Luiza Martins. Veredas de Viator. In: Cadernos de Literatura Brasileira, João Guimarães Rosa. São Paulo: Instituto Moreira Salles, 2006, p. 195.
} 
Eu não crio palavras. Elas todas estão nos clássicos, estão nos livros arcaicos portugueses. São expressões de muito valor que eu pretendo salvar. Em Sertão: Veredas há palavras que nem em Portugal se falam mais. Mas existem. Para determinadas passagens, entretanto, não existem palavras. Então é preciso criá-las, ou redescobri-las através dos sons que a correspondam. ${ }^{41}$

O elemento místico figura-se engendrando sua vida e obra:

Tenho que segredar que - embora por formação ou índole oponha escrúpulo crítico a fenômenos para-normais e em princípio rechace a experimentação metapsíquica minha vida sempre e cedo se teceu de sutil gênero de fatos. Sonhos premonitórios, telepatias, intuições, séries encadeadas fortuitas, toda sorte de avisos e pressentimentos. Dadas vezes, a chance de topar, sem busca, pessoas, coisas e informações urgentemente necessárias. ${ }^{42}$

O relato de Ana Luiza Martins Costa de fato nos dá a medida dos sutis estratagemas do destino e sua atenção para com o momento a ser registrado corroborando seu depoimento de que "Quem olha estudiosamente fotografa o momento e o revela na retina" ${ }^{43}$

Em sua juventude, em Belo Horizonte, os anos entre 1918 e 1930 foram marcados por sérios embates políticos, violentas disputas no interior de Minas, caçadas a jagunços e tropas do governo que penetravam o sertão. Os fatos são narrados pelo seu tio, João Lima Guimarães, advogado em Curvelo, e pelos amigos cujos pais estavam envolvidos diretamente nessas disputas.

Surgem nomes como os de Antônio Dó, que invadiu a cidade em 1913, e Andalécio, de São Francisco; do delegado de capturas Felão, de Curvelo; do coronel Ricardo Gregório, de Curralinho, atual Corinto; do coronel Ornelas, de Goiás e Rotílio Manduca, proprietário da fazenda Baluarte e familiares do Barão de São Romão, políticos de Januária. ${ }^{44}$

\footnotetext{
41 "Guimarães Rosa por ele mesmo: O escritor no meio do redemunho" In: Cadernos de Literatura Brasileira: João Guimarães Rosa. Instituto Moreira Salles, São Paulo, 2006, p. 82.

${ }^{42}$ Ibid., p.92.

${ }^{43}$ COSTA, Ana Luiza Martins. Veredas de Viator. In: Cadernos de Literatura Brasileira, João Guimarães Rosa. São Paulo: Instituto Moreira Salles, 2006, p. 84.

${ }^{44}$ Ibid., p. 13.
} 
Nós, homens do sertão, somos fabulistas por natureza. (...) No sertão o que pode uma pessoa fazer do seu tempo livre a não ser contar estórias? A única diferença é simplesmente que eu, em vez de contá-las escrevia. (...) Eu trazia sempre os ouvidos atentos, escutava tudo o que podia e comecei a transformar em lenda o ambiente que me rodeava, porque este, em sua essência, era e continua sendo uma lenda. ${ }^{45}$

Os fatos da realidade pessoal e histórica de Rosa, somados à memória notável do autor e sua admiração pela fabulação e pelo ambiente em que crescera, convergirão todos, estórias, personagens e cenários para sua obra maior, lançada em 1956, Grande Sertão: Veredas.

Guimarães Rosa reinventou o modo como o autor pode relacionar-se com a cultura e o mundo da linguagem. Sua ficção poética centra-se na realidade, na experiência da vida social, cuja pesquisa e registro emergem do seu trabalho: " $O$ inconformismo com o meio de expressão, empobrecimento de vocabulário, rigidez de fórmulas e formas, estratificação de lugares comuns, como caroços num angu ralo, vulgaridade, falta de sentido de beleza, deficiência representativa" 46 levam-no a eleger a variedade linguística geradora de uma terminologia própria, fundindo em uma só língua termos arcaicos e contemporâneos, clássicos e populares, sertanejos e inusitados.

Ao esquadrinhar os limites do território sertanejo, que reúne um conjunto de conhecimentos socioculturais e linguísticos de um grupo, transforma-o em palco no qual manifesta modelos preexistentes a sua imaginação. Recria uma língua étnica por excelência, repleta de marcas semânticas, sintáticas, morfológicas em que revive um idioma impresso em sua memória e gera outro, repleto de multiplicidades e transformações a partir de modelos culturais, sociais e linguísticos, formalizados em grandezas-signos dotadas de expressão e conteúdo, símbolos da realidade mesma.

\footnotetext{
45 “Guimarães Rosa por ele mesmo: O escritor no meio do redemunho" In: Cadernos de Literatura Brasileira: João Guimarães Rosa. Instituto Moreira Salles, São Paulo, 2006, p.78,79.

${ }^{46}$ COSTA, Ana Luiza Martins. Veredas de Viator. In: Cadernos de Literatura Brasileira, João Guimarães

Rosa. São Paulo: Instituto Moreira Salles, 2006, p. 188.
} 
2.3 A herança da cultura popular

A sutileza da significação dos vocábulos-termos rosianos, cujo entendimento os falantes da língua geral não dominam, nos direciona, em uma primeira etapa, a refletir sobre os indícios da cultura popular brasileira, tão rica quanto desconhecida em sua vastidão, que possam caracterizar o discurso etnoliterário e as concepções linguísticas de um grupo e suas relações com as denominações.

De fato, conseguimos apurar estudos valiosos dentre os quais a obra de Leonardo Arroyo, A Cultura popular em Grande Sertão: Veredas, que caracteriza o romance Grande Sertão: Veredas como obra manifesta de acumulação de cultura no que tange ao tema que a percorre, e às formas usadas para dar evidência a essa herança. ${ }^{47}$

A inspiração, intuição e revelação que prevalecem, como asseverou Rosa, sobre a essência intelectual de sua obra, levam-no a contar, escrevendo como se apenas falasse, fixando no tema e na forma o significado da palavra romance que, ao longo dos tempos, assumiu significados diferentes.

De acordo com Arroyo, cabe bem a Grande Sertão a palavra romance tomada em seu significado atual, mas também no tradicional de composição contada ou narrada pelo povo, do qual Riobaldo seria o representante. ${ }^{48}$ De fato, seja pela forma ou tema, Rosa recolhe em Riobaldo a variante da estória da donzela que vai à guerra, estória contada pelo povo, "com núcleo central e aspectos formais submetidos a variações no tempo e no espaço pela contribuição do próprio povo e da tradição "49.

Arroyo cita os estudos de Carolina Michaellis de Vasconcelos que afirma que o tema da donzela que vai à guerra passou "provavelmente de França à Península Ibérica, tomando nela a forma de romance", lembrando ainda a romancista "quantos casos, hoje esquecidos, não se dariam na Idade Média e frutificariam na fantasia dos cantores do povo"

Cavalcanti Proença, em tese endossada por Arroyo, traça o percurso dos romances de cavalaria distantes séculos e séculos de Grande Sertão. De acordo com os autores, a

\footnotetext{
${ }^{47}$ ARROYO, Leonardo. A Cultura popular em Grande Sertão Veredas. Rio de Janeiro, Livraria José Olímpio Editora, 1984, p.4.

${ }^{48}$ Ibid., p. 7

${ }^{49}$ Ibid., p.7

${ }^{50}$ Ibid., p.5.
} 
integração do homem ao sertão dos gerais não é senão fruto da herança cultural trazida pelos primeiros povoadores portugueses.

Nesse meio adaptados, os jagunços são os avatares dos cavaleiros medievais e " $a$ narrativa de Riobaldo", para Arroyo:

se coloca na conceituação dos produtos culturais conservados e transmitidos pelo povo através do tempo: a tradição oral, sobrevivências históricas, folclóricas, valores consuetudinários, medicina rústica e remanescentes de leituras, principalmente da literatura medieval. ${ }^{51}$

Trataremos, em primeiro lugar, do tema "da donzela que vai à guerra disfarçada de homem" $" 52$. Rosa teria demonstrado que cultivava interesse pelo tema desde o personagem de Joana Xaviel, ao escrever “Uma estória de amor”. Joana Xaviel conta, em uma passagem, a estória sobre um príncipe que indo à guerra teria se apaixonado por D. Varão, uma moça disfarçada em homem. É uma estória que correu mundo, lentamente, tendo sido dela recolhidas várias versões em tempos e lugares diversos, com diferentes títulos. A versão com o título de D. Martinho, recolhida em Felgueiras (Moncorvo, Portugal), por certo desembarcou em recônditas regiões de Minas Gerais, sem que eruditos dela tivessem se apercebido. Em "Uma estória de amor", Joana Xaviel declama a quadrinha do príncipe ao pedir conselhos aos pais, quadrinha essa escrita por Rosa:

\author{
"Pai, ô minha Mãe, ô! \\ estou passado de amor... \\ Os olhos de D. Varão \\ É de mulher, de homem não!"53
}

A versão de D. Martinho foi, com certeza, recolhida por Rosa dada a curiosa semelhança entre as quadrinhas, nas quais tanto os vocativos portugueses como a concordância são abrasileirados.

\footnotetext{
${ }^{51}$ ARROYO, Leonardo. A Cultura popular em Grande Sertão Veredas. Rio de Janeiro, Livraria José Olímpio Editora, 1984, p. 82.

${ }^{52}$ Ibid., p.31, 32 .

${ }^{53}$ Ibid., p. 31.
} 
"Ó meu pai, ó minha mãe

Oh, que dor de coração!

Os olhos de D. Martinho

São de mulher, de homem não". 54

Não desconhecemos, por outro lado, que principalmente em regiões do Nordeste do nosso país, inconformados com o nascimento de filha mulher, vários pais tratavam de vestir as filhas de homem, e assim disfarçadas faziam com que os ajudassem na lida nos campos. Este é um assunto que está diretamente ligado aos costumes desenvolvidos por um grupo e sua forma de lidar com a realidade.

Arroyo, em sua pesquisa, cita que:

Ao estudar o homem do Vale do São Francisco, não tem dúvidas Donald Pierson, em considerar que a cultura local é predominantemente de folk, onde mal se disfarça um sistema de ideias, atitudes, crenças, práticas e comportamentos herdados da Europa Medieval, de culturas africanas e de culturas ameríndias autóctones. ${ }^{55}$

Também Cavalcanti Proença concorda com a tendência popular arcaizante e suas influências no próprio léxico:

Mas o tipo cavalheiresco de Riobaldo despertou, associativamente, no acervo de impressões de leitura do autor, ressonâncias que acabaram por sintonizar até os componentes do romance, onde se pode rastrear uma propensão arcaizante de efabulação, com reflexos no próprio vocabulário. ${ }^{56}$

De fato, no conteúdo linguístico do léxico rosiano estão presentes a base arcaica misturada a brasileirismos, amalgada ao uso literário dessas formas. Aponta Nei Leandro de

\footnotetext{
${ }^{54}$ ARROYO, Leonardo. A Cultura popular em Grande Sertão Veredas. Rio de Janeiro, Livraria José Olímpio Editora, 1984, p.32.

${ }^{55}$ Ibid., p.121.

${ }^{56}$ PROENÇA, Manuel Cavalcanti. Trilhas no Grande Sertão. Os cadernos de Cultura. Ministério de Educação e Cultura, 1959, p.15.
} 
Castro $^{57}$ que Fidelino de Figueiredo observou no falar de Riobaldo características que lembram o saiaguês (falar típico da Comarca de Saiago), possivelmente uma solução literária repleta de regionalismos e arcaísmos obsoletos, mas que chegou a ser usado nos autos vicentinos. O uso do vocábulo "aspeito" no relato de Riobaldo é um dos inúmeros exemplos: "[...] a forma do substantivo é arcaica (usual nos séculos XV e XVI, segundo Viterbo) enquanto o adjetivo é regionalismo paulista: "Medeiro Vaz estava ali, num aspeito repartido", comprovado por Nei Leandro de Castro nos Lusíadas, de Camões, e que, segundo ele, os léxicos atualmente não registram:

\footnotetext{
E com risonha tristeza e ledo aspeito Responde ao embaixador que tanto estima Toda suspeita má tirai do peito, Nenhum frio temor em vós se imprima. ${ }^{58}$
}

Não somente o fenômeno arcaizante com reflexos no léxico de Grande Sertão: Veredas, mas também o uso de latinismos ou de palavras cultas, de palavras e expressões populares, de brasileirismos, de regionalismos, de alguns vocábulos de origem tupi e palavras não dicionarizadas, colhidas junto ao sertanejo, traduzem os temas da cultura popular, reinam na denominação das superstições, crenças, usos e costumes, na denominação da flora e fauna, na denominação dos lugares, de acidentes geográficos, no gosto tão sertanejo de nomear pessoas com alcunhas, apelidos e longos nomes.

Arroyo lista as palavras do léxico de Riobaldo originárias da herança cultural e do meio em que vive, como por exemplo, réis-coado, xererém, tutumumbuca, sebaça, caipora, quicé, rutumba, capanga, mariquita, guaimoré, bedegas, mas também relaciona expressões que têm ecos no meio cultural do sertanejo: Deus no céu e Joca Ramiro na outra banda do rio; falando às flautas; nação de maracatu; anta empoçada; mandioca-mansa; mandiocabrava; cabaças para boia de anzol; carro de bois; madeiras para feitura de canoas; tempo em que tudo falava. ${ }^{59}$

\footnotetext{
${ }^{57}$ CASTRO, Nei Leandro de. Universo e Vocabulário de Grande Sertão. Rio de Janeiro: Livraria José Olimpio Editora, 1970, p.10,11.

${ }^{58}$ ARROYO, Leonardo. A Cultura popular em Grande Sertão Veredas. Rio de Janeiro, Livraria José Olímpio Editora, 1984, p. 22.

${ }^{59}$ Ibid., p. 122.
} 
Também as pesquisas sobre a criação de palavras na bacia do rio São Francisco demonstram que se trata de um processo muito comum entre seus habitantes.

Rosa observou a competência linguística do sertanejo ao criar termos exatos para denominar sua realidade, e descrever, por exemplo, os defeitos de seus cavalos e as cores dos seus bois.

O capiau está mais certo: com o vocabulário involuntariamente escasso de que dispõe, gosta da ostentação, de opulência, de beleza, de inventar nomes. Para os defeitos de seus cavalos e as cores dos seus bois, dá-se a um luxo incrível de termos exatos, marcando as mínimas gradações. Gente esperta! $!^{60}$

Observemos que Rosa, ele mesmo, classifica como termos as soluções denominativas produzidas pelo "capiau". Embora venhamos a abordar mais precisamente esse tema, cumpre ilustrarmos a referência do escritor com um exemplo extraído de Grande Sertão: “Escolhi um, animal vistoso, celheado, acastanhado murzelo, que bem me pareceu; e dei em erro, porque ele era meio sendeiro e historiento." ${ }^{\prime 1}$ Trata-se do domínio linguístico específico, característico da articulação linguística que engendra significações no seio do grupo dos sertanejos dos gerais. A denominação, no caso “acastanhado murzelo”, rompe os vínculos específicos para com a função vocábulo e a função termo e se formaliza em grandeza-signo da realidade que os teceu.

Em que pese o pequeno trecho conter outros três adjetivos que contribuem para enriquecê-lo com marcadores de etnicidade, "murzelo" é cor, que conforme o Novo Dicionário Aurélio, "diz-se de, ou o cavalo morado", "cor de amora". Verificamos no dicionário de Nilce Sant'Anna Martins: palavra originária do latim vulgar, cavalo cor de amora, preto, que, sabemos foi recolhida e identificada no contato de Rosa com o sertanejo.

Leonardo Arroyo, dentre alguns autores, cita Renato Mendonça: "na loquela dos sertanejos são-franciscanos, em virtude do seu segregamento” há uma aproximação maior "com o português seiscentista que do atual português de Portugal",62 e do Brasil, acrescenta.

\footnotetext{
${ }^{60}$ COSTA, Ana Luiza Martins. Veredas de Viator. In: Cadernos de Literatura Brasileira, João Guimarães Rosa. São Paulo: Instituto Moreira Salles, 2006, p.190.

${ }^{61}$ ROSA, João Guimarães. Grande Sertão: Veredas. Rio de Janeiro: Nova Fronteira, 2006, p.380.

${ }^{62}$ ARROYO, Leonardo. A Cultura popular em Grande Sertão Veredas. Rio de Janeiro, Livraria José Olímpio Editora, 1984, p.21.
} 
De acordo com Arroyo, Ediberto Trigueiros é taxativo: "com sua ignorância, não os perturba, ademais, o seu exíguo vocabulário. Inventam palavras, as mais extravagantes possíveis, é verdade, mas criam-nas com convicção e muitos deles são mestres nessa esdrúxula especialidade". 63

A linguagem de Rosa capta o modo de existência como um espelho, que nem sempre é límpido, mas às vezes embaraçado, suficientemente para permitir que as palavras expliquem-se por si, àqueles que não pertencem aos domínios que refletem.

Arroyo ainda comenta que Óscar Lopes denominou "consumação de formas mais ou menos latentes" a linguagem de Riobaldo, como por exemplo a ordem frástica, diminutivos verbais ou pronominais, a virgulação, empregos de determinados tempos verbais, a plasticidade prefixal, cunhando-o de "narrador popular", "literariamente ingênuo", que com sua narrativa recuperou "toda a frescura da epopeia antiga", os jagunços avatares de Aquiles, por exemplo, de figuras do cancioneiro popular da grande herança universal ${ }^{64}$.

A expressão linguística de Riobaldo é, para Óscar Lopes: tão vívida, na sua lúcida imprecisão de primeira descoberta, como os anacolutos e as repetições dos poemas homéricos, ou como qualquer outro estilo organicamente, verdadeiramente, popular ou arcaico. Insere-se desse modo na mais legítima literatura da cultura popular. ${ }^{65}$

Acrescenta Arroyo, que a narrativa riobaldiana é cheia de volteios, sua continuidade tem algo de confusa, a interpenetrar vários níveis descritivos. A estória não é linear e encontramos tal processo na literatura popular ou de cordel, tal qual examinou Mário Pontes no "Romance o Boi Misterioso", um novo dado que se vem juntar às características do discurso etnoliterário em causa ${ }^{66}$.

Quanto ao "espírito do romance antigo", permeado da língua clássico-arcaica da infância de Rosa, a afirmação seguinte vem ao encontro das descrições do sertão em Rosa, isolado e sem fim, harmonizando-se com a conservação de uma língua insulada em grandes extensões de terra. Joaquim Ribeiro assinala:

\footnotetext{
${ }^{63}$ ARROYO, Leonardo. A Cultura popular em Grande Sertão Veredas. Rio de Janeiro, Livraria José Olímpio Editora, 1984, p.21.

${ }^{64}$ Ibid., p. 21 .

${ }^{65}$ Ibid., p.21, 22.

${ }^{66}$ Ibid., p.2.
} 
[...] usos e costumes, tradições, mitos e lendas, hábitos e linguajar retratam profunda feição arcaizante, própria da população segregada. O insulamento e o analfabetismo explicam a permanência dessa tradição secular. Quanto mais se penetra no sertão, maior é a fisionomia arcaica [...], no interior de Januária, aliás, nada se vê de moderno e de industrializado. Tudo é arcaico e antiquado. ${ }^{67}$

Trata-se de uma cultura diferenciada, com um romanceiro oral herdado típico. O mesmo Joaquim Ribeiro e M. Cacalcanti Proença citados por Arroyo foram seduzidos pelo linguajar regional da obra rosiana, que é associado aos mesmos processos de formação da linguagem dos habitantes da região em que se dão boa parte dos acontecimentos de Grande Sertão: Veredas.

Devemos lembrar que o próprio autor referiu-se ao seu idioma como sendo a fusão de dialetismos da sua região e o português da Idade Média, como aquele que fora falado em Coimbra.

O sertanejo assim isolado, como descreveu Rosa, "no imo de um estado central, conservador por natureza”, nada pode fazer ali do seu tempo a não ser contar estórias, e lembra Arroyo que é "o que permite a sobrevivência de um mundo cultural bastante original, inclusive um romanceiro típico em que se percebe invariavelmente a ação dos processos orais de herança, que atuam sempre em tais processos culturais". 68

Enfim, a expressão linguística de Riobaldo foi fidedignamente construída a partir da herança linguística arcaica, acumulada e modificada ao longo da história e na geografia isolada dos contornos das serras dos gerais.

As sobrevivências desse estilo de linguagem nos sertões dos Gerais foram conferidas pela pesquisa de Joaquim Ribeiro, se não bastasse ainda sobre o assunto, confissão do autor a Curt Meyer-Clason, quando lembrava sua utilização frequente da matéria de provérbios ou de lugares-comuns. ${ }^{69}$

\footnotetext{
${ }^{67}$ ARROYO, Leonardo. A Cultura popular em Grande Sertão Veredas. Rio de Janeiro, Livraria José Olímpio Editora, 1984, p. 07,08.

${ }^{68}$ Ibid. , p.08.

${ }^{69}$ Ibid., p. 13,14.
} 
Mary Lou Daniel enfatiza os termos empregados pelo autor e, muito importante, denunciou sua natureza especializada: "A natureza especializada de muitos dos termos brasileiros empregados pelo autor possibilita as descrições vivas e exatas da gente e das coisas regionais tão características da obra rosiana." ${ }^{, 70}$. Sublinhamos que a linguagem rosiana de especialidade adverte a todo leitor atento sobre a função inequívoca das unidades lexicais empregadas.

$2.4 \mathrm{O}$ sentido de etnia

A realidade específica do sertão mineiro, descrita por Rosa, obriga-nos a dimensionar o termo etnia e os elementos intrínsecos a ele como raça, história e visão de mundo de um grupo, ancestralidade e espaço geográfico, conhecimentos e concepções compartilhados.

Os sertanejos das regiões nordeste de Minas e oeste da Bahia e de Goiás são, por vínculo linguístico e social, herdeiros do índio e dos europeus que habitavam a América, principalmente dos portugueses, dos índios e dos negros que afluíram, por diferentes razões, àquela região. Houve, por parte dos diferentes grupos, adaptação às condições naturais e às oportunidades sociais que constituiriam sua identidade étnica.

Conforme Dick nos esclarece:

O entendimento do termo etnia, ou o seu próprio conceito definidor, passa, antes, pelo crivo de vários fatores intrincados entre si, como localização espacial do grupo em questão, situação sociológica interna, tipologia das sociedades, práticas culturais características dos contatos [.....], o próprio corpus linguístico utilizado no extrato comunicativo. $^{71}$

A diferenciação identitária do grupo habitante dos gerais e as diferenças observáveis no léxico ocorreram, à semelhança de outros grupos distribuídos pelo Brasil, como os gaúchos, sob a influência dos italianos e alemães, a partir do ancestral e da língua comuns, em

\footnotetext{
${ }^{70}$ DANIEL, Mary Lou. João Guimarães Rosa: Travessia Literária. Rio de Janeiro, Livraria José Olímpio, 1968, p.25.

${ }^{71}$ Dick, Maria Vicentina de Paula do Amaral. Etnia e etnicidade: um outro modo de nomear. Projeto

ATESP/ATB. In: ISQUERDO, Aparecida Negri; KRIEGER, Maria da Graça. As ciências do léxico. v. II, 2004.
} 
torno dos quais foram preservados vínculos e conteúdos socioculturais, históricos e psicológicos, religiosos e cosmovisão. A fixação do grupo em um espaço geográfico único é o fator que agrega e sedimenta os elementos necessários para caracterizar uma etnia, muito embora não seja o fator determinante para sua caracterização. Rosa, por exemplo, dizia aos seus tradutores, mergulhados nas traduções, que eram, como ele, sertanejos.

Como a identidade cultural se constrói com base na tomada de consciência das diferenças, provindas das particularidades históricas, culturais, religiosas, sociais, regionais, etc., se delineiam no Brasil diversos processos de identidade cultural, revelando pluralismo tanto entre negros, quanto entre brancos e entre amarelos, todos tomados como sujeitos históricos e culturais e não como sujeitos biológicos ou raciais. $^{72}$

O atributo étnico toma forma, não mais relacionado à raça em sua primazia, pois o contato entre raças é inevitável, e não também relacionado à cultura em sentido primário, pois cultura é entendida como conhecimentos e percepções, produtos do grupo étnico. " $O$ critério hoje vigente, que define grupo étnico como forma de organização social (é aquele) em que seus membros se identificam e são identificados como tais pelos outros, constituindo-se em categorias distintas de outras categorias da mesma ordem". 73

No caso específico do sertanejo do Brasil Central, a localização de difícil acesso, aliada à preferência dos portugueses pelo povoamento das regiões litorâneas, manteve o insulamento da região central do país, mesmo depois de tantos séculos. As características dos diversos grupos humanos oriundos de diversas regiões do mundo que ocuparam aquele espaço, se rearticulando e promovendo enriquecimento mútuo, as práticas sociais e culturais estabelecidas enquanto produto de suas relações, e sobretudo o conteúdo e a forma do corpus linguístico enquanto manifestação de etnicidade, convergiram para a conceptualização distinta do sertanejo dos Gerais, conceptualização esta que é produto de uma realidade e que, ao mesmo tempo, a condiciona.

\footnotetext{
${ }^{72}$ MUNANGA, Kabengele. Uma abordagem conceitual das noções da raça, racismo, identidade e etnia. Palestra proferida no $3^{\circ}$. Seminário Nacional. Relações raciais e educacionais. PENESB-RJ. Em 04 de nov. de 2003, p.04.

${ }^{73}$ CUNHA, Manuela Carneiro. Parecer sobre os critérios de identidade étnica. In: Antropologia do Brasil: mito, história e etnicidade. São Paulo: Brasiliense/Ed. da UNB, 1986, p.2.
} 
2.5 A concepção de mundo e sua relação com as palavras

Qualquer abordagem a respeito da linguagem utilizada por Guimarães Rosa, por mais inédita que seja, sempre, em seus resultados, impressionarão em decorrência da grandiosidade da sua obra. Isto porque os recursos expressivos do autor renovam-se a cada linha em seus aspectos sintáticos, retóricos e léxicos, e naqueles oriundos do conhecimento amealhado em pesquisas, estudos, labor, mas também enquanto produto de muita imaginação e ousadia ao lidar com a palavra. Sempre serão possíveis novos olhares que investiguem sua obra inesgotável e sua imensa fortuna crítica.

Detendo uma conceptualização própria do mundo, resultado de sua vivência multicultural, Rosa refletia, criteriosamente, conforme declarou, a respeito de cada palavra que utilizava e que só se materializava em seu texto, após um longo processo de investigação, análise e estudo. Como poucos autores, embrenhou-se no mundo das palavras, sem se limitar às estruturas linguísticas tradicionais, nem mesmo da sua própria língua.

Revelou, em entrevista a Günter Lorenz, que aprendeu várias outra línguas para melhor entender a sua e porque também há muitas coisas "intraduzíveis". Consagrou explicações à criação dos neologismos ou à redescoberta das palavras, que se tornavam necessárias quando não existissem para alguma passagem.

Nunca me contento com alguma coisa... estou buscando o impossível, o infinito. E, além disso, quero escrever livros que depois de amanhã não deixem de ser legíveis. Por isso acrescentei à síntese existente a minha própria síntese, isto é, incluí em minha linguagem muitos outros elementos, para ter ainda mais possibilidade de expressão. $^{74}$

O escritor mineiro, com seu estilo próprio e prodigioso, construiu um discurso literário que conscientemente desvela os valores sociais e culturais de um grupo humano de uma região imune, em determinada época, ao convívio cosmopolita. Escolheu imortalizar em suas obras o sertanejo do sertão dos Gerais.

\footnotetext{
${ }^{74}$ MARTINS, Nilce Sant'Anna. O Léxico de Guimarães Rosa. São Paulo, EDUSP, 2008, p. X.
} 
A sua conceptualização do universo funde-se a uma visão, por assim dizer, já estabelecida no antropocultural. Fundem-se seu entendimento geral, que é acessível à maioria dos indivíduos da mesma cultura, e sua visão de mundo particular, mineirada no universo sertanejo e mundo plural, multicultural. É a linguagem que criou que lhe possibilita projetar sua conceptualização amalgamada à conceptualização do sertanejo, e na paisagem do sertão mineiro, fundir a linguagem comum com a do sertanejo, ao mesmo tempo em que ressuscita o idioma clássico-arcaico que aprendera na infância

Em carta a Mary Lou Daniel, Guimarães Rosa explica a origem da língua que usa:

\begin{abstract}
Os sertanejos de Minas Gerais, isolados entre as montanhas, no imo de um estado central, conservador por excelência, mantiveram quase intacto um idioma clássicoarcaico, que foi o meu, de infância, e que me seduz. Tomando-o por base, de certo modo, instintivamente tendo a desenvolver suas tendências evolutivas, ainda embrionárias, como caminhos que uso. ${ }^{75}$
\end{abstract}

Podemos perceber que o autor mineiro caracteriza no tempo e no espaço o linguajar próprio de um grupo de falantes, isolados no coração do nosso país. Entendemos este grupo sertanejo constituído por vínculos outros que não o de raça ou limites geográficos, mas preponderantemente, por relações sociais de parentesco remoto, fatores culturais como tradições, enfim, o vinculo social, a que Saussure ${ }^{76}$ chamou de etnismo e que está na base da unidade linguística rosiana.

São essas as considerações que nos levam a perguntar em que medida as palavras de uso em língua geral são revestidas de significado específico ligado às experiências, concepções e visão de mundo semioticamente construído em Grande Sertão: Veredas.

Procuraremos responder a essa questão examinando no plano linguístico e no plano conceptual os sistemas de valores subjacentes ao léxico da obra Grande Sertão: Veredas que se constituirá no corpus de análise da nossa pesquisa.

Devemos tecer considerações sobre a língua do sertanejo de Rosa e o interesse que o autor revelou por ela, as concepções de mundo e os vínculos sociais e culturais que unem os indivíduos desse grupo, histórica e geograficamente delimitado e finalmente, como a

\footnotetext{
${ }^{75}$ DANIEL, Mary Lou. João Guimarães Rosa: Travessia Literária. Rio de Janeiro: Livraria José Olímpio, 1968, p. 142 .

${ }^{76}$ SAUSSURE, Ferdinand de. Curso de Linguística Geral. São Paulo: Editora Cultrix, 1971, p.261.
} 
Etnoterminologia pode colaborar, com seus pressupostos teóricos, para esclarecer tais questões.

Do significado do grego, éthnos, raça, nação, povo com laços de sangue, hoje não resta para a Etnologia nada em seu sentido original estrito. O termo etno só faz sentido aplicando-o a um grupo de pessoas e as suas características culturais e sociais que em conjunto refletem etnicidade, ou seja, pessoas que congregam a mesma cultura, língua própria, crenças, concepção e leitura do mundo, habitando algum ponto do espaço, para poder assim ser caracterizado como um grupo diferenciado.

A pesquisa que Rosa fez do vocabulário do vaqueiro reveste-se de exatidão documental e foi recolhida diretamente na fonte, em maio de 1952. Anotada em seus famosos caderninhos durante a célebre viagem em que conduziu uma boiada de oitocentas reses, partindo da fazenda Sirga, em Três Marias, teve como consequência a recuperação, através da literatura, do vernáculo em sua forma mais "exata e pura": "Para escrever Grande Sertão: Veredas, passei um mês inteiro no mato, em lombo de mula, catalogando em um caderninho o linguajar do povo sertanejo. Há palavras que na cidade nem são conhecidas e que têm, contudo, raízes puras no latim autêntico.",77

Podemos dizer que a manifestação da língua dos sertanejos em Guimarães Rosa, em seu discurso literário, reúne qualidades não apenas da linguagem literária, mas também se reveste de sutil especificidade, visto pertencer a um grupo de falantes portador de um corpus linguístico de entendimento restritivo para aqueles que não participam da mesma realidade.

\footnotetext{
${ }^{77}$ COSTA, Ana Luiza Martins. Veredas de Viator. In: Cadernos de Literatura Brasileira, João Guimarães Rosa. São Paulo: Instituto Moreira Salles, 2006, p.190.
} 


\title{
3. FUNDAMENTOS TEÓRICOS
}

Os fundamentos teóricos que nos permitirão examinar o "mundo semioticamente construído por Rosa" partem das pesquisas e produção acadêmica de Maria Aparecida Barbosa e Cidmar Teodoro Pais. Seus pressupostos teóricos deverão comprovar a hipótese de que mesmo as palavras de uso em língua geral assumem significado específico no universo de discurso de Grande Sertão: Veredas,

A Etnoterminologia, a mais nova disciplina das ciências da linguagem, da qual Maria Aparecida Barbosa é mentora, proveu o suporte para o estudo do sistema de conhecimentos herdados por um grupo social, uma etnia, cultural e linguisticamente idiossincrática: seus valores, crenças e saber compartilhado sobre o mundo.

3.1 A renovação das estruturas lexicais e sua interação com a evolução do saber

\begin{abstract}
On ne peut parler des phénomènes linguistiques sans préciser l'optique dans laquelle on se place. L'individu qui utilize la langue se trouve soit dans la situation de l'émetteur, soit dans celle du récepteur, passant fréquemment de l'une à l'autre. Quant au linguiste, il est l'observateur qui tente de dégager les mécanismes pouvant rendre compte de ce double fonctionnement. Il est lui-même l'émetteurrecepteur qui réfléchit sur ses competences et recherche les operations mises en jeu dans ces deux fonctions communicatives: la conception du parcours onomasiologique (des intentions de DIRE vers les manifestations linguistiques) et l'intreprétations du parcours sémasiologique (des textes ou messages complexes aux constructions de sens qui permettent de COMPRENDRE) ${ }^{78}$
\end{abstract}

Situamo-nos, na análise do universo léxico de Grande Sertão: Veredas, em uma etapa sincrônica do universo de discurso rosiano, considerando, porém, a concepção pósestruturalista de sistema e língua, na qual as unidades lexicais têm sua gênese nas virtualidades do sistema, que se renova de modo inexaurível. Tal dinâmica de sistema

\footnotetext{
${ }^{78}$ POTTIER, Bernard. Sémantique générale. Presses universitaries de Paris. Paris, 1992, p.13.(Não podemos falar dos fenômenos linguísticos sem precisar a ótica na qual nos colocamos. O indivíduo que utiliza a língua se encontra na situação de emissor, ou de receptor, passando frequentemente de uma a outra. Quanto ao linguista, ele é o observador que tenta desembaraçar os mecanismos que possam traduzir este duplo funcionamento. Ele é o próprio emissor-receptor que reflete sobre suas competências e pesquisa as operações em jogo das duas funções comunicativas: a concepção do percurso onomasiológico (as intenções de DIZER versus as manifestações linguísticas) e a interpretação do percurso semasiológico (os textos ou mensagens complexas na construção do sentido que permitem COMPREENDER)). (Tradução nossa).
} 
compreende a estrutura linguística em interação com o contexto sociocultural. Regida pelo contexto, a criação lexical dá-se, como ensinou Hjelmslev, a partir de um princípio universal de formação e, em sentido inverso, o conhecimento elaborado, uma vez formulado em grandeza-signo, é recuperado pelo sistema e pode a ele integrar-se, repercutindo em nova conceptualização e, por conseguinte, modificando a visão de mundo do falante-ouvinte.

Cidmar Teodoro Pais postula que o processo histórico da cultura é o todo constituído pelas ciências, que elaboram diferentes universos de discurso. Nestes universos de discurso refletem-se os processos de produção, a prática social e o fazer cultural da humanidade. As ciências da linguagem, por sua vez, encontram sua metateoria para a explicação da produção do saber sobre o mundo (episteme), e de produção de significação (semiose) no conjunto das ciências humanas e sociais. Assim, o estudo das semióticas em seu conjunto explica o mundo semioticamente construído por um grupo sociocultural, conjunto este sustentado e permanentemente reelaborado no tempo e no espaço. Com efeito, esse dinamismo se espraia nas ciências como um todo, renovando-se a partir dos resultados das pesquisas que, realizadas, constituem ponto de partida para formulações de novas hipóteses. ${ }^{79}$

É a continuidade que assegura a intercompreensão; a certeza de mudança atende ao processo de renovação no âmbito do progresso da humanidade como um todo. Sobretudo o sistema linguístico responde com presteza às transformações do meio social, mas também os sistemas semióticos em geral, com a incorporação concomitante de novos signos, configurando o processo de interdependência entre língua, cultura e sociedade. Assim, fica mais bem esclarecido por Maria Aparecida Barbosa:

\footnotetext{
Os sistemas semióticos sustentam-se, com efeito, numa tensão dialética imprescindível ao seu pleno funcionamento - entre duas forças contrárias, não excludentes mas complementares, a da conservação e a da mudança. A oscilação entre as duas tendências ocorre sem que os falantes se apercebam, as mais das vezes, que a língua deixa de ser idêntica a si mesma, enquanto falam. A força de conservação assegura a continuidade histórica e a intercompreensão dos sujeitos falantes-ouvintes da comunidade; a força de mudança capacita a língua a atender às novas necessidades de comunicação e do processo de renovação social. ${ }^{80}$
}

\footnotetext{
${ }^{79}$ PAIS, Cidmar Teodoro. Dos estudos pré-linguísticos a semiótica das culturas: abordagem históricoepistemológica.In: Revista Acta Semiótica et Lingvistica. v.12, nº. 2, ano 31, SBPL, p.123-130.

${ }^{80}$ BARBOSA, Maria Aparecida. Campo conceitual e campo lexical dos termos globalização e mundialização: relações.In: Revista Brasileira de Linguística, São Paulo, v. 10, nº.1, p. 29-52, 1999.
} 
A complexa investigação nos diferentes grupos socioculturais, no que tange às suas escolhas linguísticas e aos processos semióticos entendidos como produção das formas de significação e produção de novas informações, leva-nos a considerar a concepção de mundo, os valores que permeiam as relações humanas e a elaboração do saber e do saber-fazer em diferentes universos de discursos, que têm, como vimos, na dinâmica da renovação das estruturas lexicais sua instância privilegiada.

O universo lexical renovado representa o modo de apreensão das especificidades, multiplicidades e das transformações dos modelos culturais e sociais. Trata-se de um processo que se formaliza no léxico dos universos de discursos em grandezas-signos dotadas de expressão e conteúdo, decorrentes da necessidade de denominar o universo antropocultural. Dessa perspectiva, as pesquisas sobre a língua e fenômenos da linguagem se constituem em um instrumento de análise sobre a própria natureza humana, pois a dinâmica linguística manifesta as transformações sociais e culturais na trajetória histórica constante do homem, gerando novas grandezas-signo.

As distinções no modo de falar os fatos, além de explicarem o universo referencial, aglutinam e dão identidade aos grupos humanos e são marcas dos seus conhecimentos, informações sobre sua natureza social e cultural, herança de costumes e crenças. É a língua que os caracteriza uns em oposição aos outros, e por esse motivo o processo de produção da significação e da informação sempre despertou interesse por parte dos estudiosos das ciências da linguagem.

$\mathrm{Na}$ determinação dos fundamentos teóricos para comprovar a hipótese de que mesmo as palavras de uso em língua geral assumem significado específico no universo de discurso de Grande Sertão: Veredas, examinaremos o "mundo semioticamente construído por Rosa" à luz dos pressupostos teóricos de Maria Aparecida Barbosa e Cidmar Teodoro Pais.

De acordo com Pais ${ }^{81}$, a concepção atual de sistema e estrutura compreende língua e discurso dialeticamente articulados, constitutivos do processo semiótico. O estudo da produção de saber sobre o mundo (episteme), e da produção de significação (semiose), no conjunto das semióticas, explica o mundo semioticamente construído por uma comunidade sociocultural, conjunto este sustentado e permanentemente reelaborado no tempo e no espaço em que a comunidade se insere.

\footnotetext{
${ }^{81}$ PAIS, Cidmar Teodoro. Dos estudos pré-linguistícos e linguísticos a semiótica das culturas: abordagem histórico-epistemológica. In: Revista Acta Semiótica et Lingvistica. v.12, nº. 2, ano 31, SBPL, p.132-139.
} 
Este dinamismo se espraia no processo histórico da cultura que é o todo constituído pelas ciências, que elaboram diferentes universos de discurso, nos quais se refletem os processos de produção, a prática social e o fazer cultural da humanidade como um todo inacabado, que tem continuidade a partir das pesquisas realizadas que se constituem em ponto de partida para a formulação de novas hipóteses.

Atualmente articulamos dialeticamente as concepções sincrônica e diacrônica de língua e discurso, enquanto instrumento de comunicação e enquanto processo semiótico. Nesta visão pós-estruturalista, língua e discurso articulam-se, funcionam e mudam, elaborando e reelaborando constantemente a visão de mundo de uma comunidade, que compartilha seu saber e práticas culturais, assegurando sua identidade cultural e memória social.

Uma vez que selecionamos na análise de Grande Sertão: Veredas sua vertente etnoliterária, estudaremos também, em nossa fundamentação teórica, os pressupostos da Etnoterminologia, sob a ótica de sua mentora, Maria Aparecida Barbosa.

O mundo semioticamente construído por G. Rosa se instaura na perspectiva defendida por A. J. Greimas de que "os discursos etnoliterários são discursos construídos nas línguas naturais e no mundo natural, lugares de manifestação de numerosas semióticas ${ }^{\text {"82. }}$.

A Etnoterminologia, capaz de descrever e analisar a unidade lexical existente entre o termo e o vocábulo, o vocábulo-termo característico desses discursos, colabora em sua análise. No universo de discurso etnoliterário, os movimentos entre vocábulo e termo se presentificam em razão da simultaneidade de valores e funções que conferem estatuto exclusivo a essas unidades léxicas.

A Etnoterminologia se apresenta, pois, como a mais nova disciplina das ciências da linguagem com suporte para o estudo do sistema de conhecimentos de um grupo social, de uma etnia, cultural e linguisticamente idiossincrática: seus valores, crenças e saber compartilhado sobre o mundo, retirando do universo de discurso etnoliterário seu objeto de estudo.

O momento da denominação integra o conceito formado ao signo linguístico. $O$ conceito corresponde a um modelo "mental" e se constitui em um subconjunto de noemas, que podem ser universais, ideológicos-culturais e ideológicos-intencionais-culturais que estudaremos adiante, valendo-nos do arcabouço teórico de Maria Aparecida Barbosa.

${ }^{82}$ GREIMAS, A J. ; COURTÉS, J. Dicionário de Semiótica, São Paulo, Contexto, 2008, p.449. 
Pais assim sintetiza a concepção dinâmica de discurso, que selecionamos para nossa análise:

[...] o único lugar que pode dar-se a semiose, ou seja, a produção de significação. Nesses termos, dir-se-á que o discurso é produtivo, na medida em que produz sempre - embora em proporções variáveis - significação e informações novas, isto é, funções semióticas e metassemióticas lato sensu e seus correspondentes recortes culturais, numa reorganização dos "referentes", numa reelaboração evidentemente parcial, de uma visão de mundo, no engendramento de designationes e designata. ${ }^{83}$

De acordo com Barbosa, um sistema de significação tem a capacidade ampla de instaurar e transformar as relações intrassígnicas e a produção de enunciados. O seu elemento permanente é a semiose ${ }^{84}$.

Pais ilustra, em minucioso artigo, que a concepção, até então estática de língua, evoluiu no período pós-estruturalista, para uma concepção dialética ou dinâmica de sistema e estrutura cujo funcionamento no seio da vida social e mudança no eixo da História constituem um único processo. Refere que, desde a Antiguidade Clássica, as pesquisas e reflexões sobre a linguagem desenvolveram-se em ciclos alternados, marcados por períodos de "postura eminentemente descritiva", ou "postura eminentemente marcada pela historicidade"

Os estudos das relações entre língua, linguagem e discurso, atualmente se fazem no terreno da pancronia e da pancronia ampla, buscando articular descrição e historicidade. ${ }^{86}$

Sabemos que os processos capazes de gerar os signos linguísticos e a busca pela significação dos diferentes conjuntos significantes se apresentam num patamar diferenciador a partir do livro de A. J. Greimas, Semântica Estrutural. Dos postulados de L. Hjelmslev para o plano de expressão e o plano do conteúdo, Greimas, apoiando-se também em Saussure, define que a função semiótica se estabelece a partir da relação de pressuposição recíproca entre forma da expressão e forma do conteúdo, produzindo signos. ${ }^{87}$

\footnotetext{
${ }^{83}$ PAIS, Cidmar Teodoro. Texto, discurso e universo de discurso: Aspectos das Relações entre Enunciação e Enunciado. In: Revista Brasileira de Linguística, São Paulo, v.14, no .1, Terceira Margem, 2006, p.09.

${ }^{84}$ BARBOSA, Maria Aparecida. Reflexões epistemológicas sobre a pancronia: meta-modelos pancrônicos. In: Revista Acta Semiótica et Lingvistica, SPBL, Editora UBC, vº 11, 2006, p.37.

${ }^{85}$ PAIS, Cidmar T. Dos Estudos pré-linguísticos e linguísticos a semiótica das culturas: abordagem históricoepistemológica. In: Revista Acta Semiotica et Lingvistica, vo. 12, no. 2, ano 31, p.124.

${ }^{86}$ Ibid., p.124.

${ }^{87}$ GREIMAS,A. J. ; COURTÉS, J. Dicionário de Semiótica, São Paulo, Contexto, 2008, p.447, 448.
} 
Hjelmslev insistiu em afirmar que não há conhecimento ou descrição científica de qualquer objeto sem que seja concebido como uma estrutura. No estudo dos fatos semânticos, estrutura introduz a noção de valor ao lado da noção de significação, e Hjelmslev postula métodos análogos aos usados no plano de expressão, partindo do isomorfismo entre o plano da expressão e o plano do conteúdo. Tendo, pois, como modelo a análise das figuras do plano da expressão (fonemas), Hjelmslev propôs, também, a redução das classes abertas de que o léxico é composto, no plano do conteúdo (semas) a classes fechadas. Propôs enfim, na análise semântica, que se considerasse o uso semântico adotado nas avaliações, opinião social e apreciações coletivas de uma comunidade que, enfim, contribuem em diferentes resultados em uma investigação linguística.

A unidade lexical passou a ser considerada na totalidade do contexto do seu emprego, de suas relações formais, estilísticas, históricas, sendo seu sentido definido a partir das estruturas de um sistema linguístico.

Em Prolégomènes à une theorie du langage, Hjelmslev concorda com Saussure e com Weisgerber que concebem o signo como um todo formado por expressão e conteúdo, que até então era tido como sinal de alguma coisa, e introduz a noção de função semiótica posta em solidariedade entre duas grandezas, uma expressão e um conteúdo, função esta que só existe com a presença simultânea destes dois "fonctifs", que por eles mesmos não podem existir também sem a função semiótica que os una.

O que existe em comum a todas as línguas é o fator que as liga ao princípio de estrutura, a que Hjelmslev denominou "sens". Trata-se do fator que garante que a substância existe. O "sens" não formado tem forma diferente em cada língua, na qual são estabelecidas suas fronteiras na "massa amorfa" do pensamento, pondo em valor diferentes fatores, tomados em diferentes ordens. O sentido não tem existência possível senão a de ser a substância de uma forma qualquer.

As contribuições de Hjelmslev seriam decisivas para o futuro da Semântica Estrutural Lexical, ao delimitar a natureza do signo linguístico enquanto uma unidade constituída pela forma de conteúdo e a forma de expressão (a estrutura fonológica do signo) estabelecida pela solidariedade a que chamou função semiótica, sendo suas relações fundamentais para a estrutura da língua.

É importante relembrarmos as contribuições de Greimas, o grande teórico da Semântica Estrutural, no que concernem à semântica de língua. Concorda com Saussure para quem a língua é feita de oposições, "sincronicamente, isto é, no ato da percepção, a 
apreensão das significações do real é feita através da afirmação de descontinuidades e dos espaços diferenciais, como o fez Lévi-Strauss" ${ }^{\prime 88}$.

Seu estudo está voltado para unidades pequenas do discurso e a estrutura elementar da significação, o que significa dizer, seu modo de existência, implica na presença de dois termos-objeto e de um vínculo que constitui uma relação, ou seja, o mundo se organiza em formas através das diferenças. A significação pressupõe a existência dessa relação necessária e simultânea, que pode ser conjuntiva (quando os termos-objeto têm algo em comum, seus parciais iguais), ou disjuntiva (com alguma diferença que os distingue, seus parciais diferentes).

Sobre a forma e substância, Greimas explica que as diferentes articulações sêmicas se definem em um grande número de eixos semânticos:

\begin{abstract}
Estas articulações sêmicas diferentes - que caracterizam, é claro, não somente o espectro das cores, mas um grande número de eixos semânticos - são apenas categorizações sêmicas do mundo, que definem, em sua especificidade, as culturas e civilizações. Por isso mesmo, não é de espantar que Hjelmslev tenha reservado a essas articulações o nome de forma do conteúdo e tenha designado os eixos semânticos que totalizam como substância do conteúdo o denominador comum a cada termo oposto. É o fundo sobre o qual se salienta a articulação da significação de dois termos-objeto, com a função de englobar e totalizar as articulações que lhes são inerentes, a que Saussure denominara de elementos diferenciais. ${ }^{89}$
\end{abstract}

Ao permanecer no plano fenomenológico postulando com Russel que "as qualidades definem as coisas", Greimas amplia a definição de estrutura: "é o modo de existência da significação, caracterizada pela presença da realização articulada entre dois semas". Assim dá o nome de lexema ao termo-objeto, pertencente à língua objeto, que se realiza no discurso que nada mais é que "um conjunto de semas ligados entre si por relações hierárquicas" 90. Convém considerarmos o lugar que cabe ao lexema em sua ponderação:

\footnotetext{
${ }^{88}$ GREIMAS, A. J. A Semântica Estrutural. São Paulo, Cultrix, 1973, p.27.

${ }^{89}$ Ibid., p. 37

${ }^{90}$ Ibid., p.38, 39.
} 
Mas o lexema é um lugar de encontro histórico. Com efeito, apesar de seu caráter fixo, o lexema é da ordem do acontecimento e se encontra, como tal, submetido à história. Isso quer dizer que, no curso da história, os lexemas se enriquecem de novos semas, mas que essa mesma história, isto é, no limite a distância que separa um processo de comunicação de outro (pois a diacronia pode compreender durações de cinco segundos como de cinco séculos), pode esvaziar os lexemas de alguns de seus semas. ${ }^{91}$

Concluímos que, na análise do funcionamento da língua, da linguagem e do discurso, a preocupação com o processo de produção da significação e da informação que conduziriam ao desenvolvimento de modelos pancrônicos no período pós-estruturalista, foi longamente gestada a partir da construção dos modelos pós-estruturalistas que se desenvolveram desde Hjelsmlev. O estatuto de ciência da significação se foi incorporando à Semântica à custa de incansáveis e permanentes reelaborações, determinadas pelo processo histórico no desenvolvimento das ciências da linguagem. A reformulação da concepção de estrutura de língua em interação com as estruturas social e cultural viria a deslindar o estruturalismo clássico da concepção pancrônica de sistema em sentido amplo.

A concepção pancrônica, no sentido amplo de sistema de significação a partir da interação das estruturas linguísticas, sociais e culturais, e o reconhecimento do dinamismo dos sistemas semióticos inter-relacionados, também são fatores que contribuíram para o entendimento do funcionamento e das diferentes manifestações da linguagem.

Se a pancronia se sustenta e subsiste na dialética entre dois termos contrários e não contraditórios, diacronia e sincronia, e, se a predominância de um desses termos depende da época, do contexto e do autor analisados, verificamos que, no caso de Rosa, grande parte do vocabulário de suas obras se prende a uma sincronia arcaizante. Em outros termos, reflete o vocabulário de um grupo social que utiliza as palavras efetivas, ligadas a um tipo de falar sedimentado, que poucas transformações sofreu ao longo do tempo. Existe, entretanto, em outras obras do mesmo autor, uma vontade ferrenha de renovação de palavras, que reflete um universo próprio e característico, caso de Primeiras Estórias.

Nosso trabalho focaliza sobretudo o primeiro tipo de vocabulário: registro das palavras tais como são utilizadas pelos falantes da região. Por outro lado é esse aspecto que será analisado e descrito no capítulo de análise dos dados, que justifica, ao nosso ver, a abordagem etnoterminológica do trabalho, abordagem essa que enfatiza sobretudo o que é específico de um grupo, de uma etnia, no que concerne ao vocabulário.

\footnotetext{
${ }^{91}$ GREIMAS, A. J. A Semântica Estrutural. São Paulo, Cultrix, 1973, p.52.
} 
Entretanto, como o primeiro conjunto prevalece sobre o segundo, já que em todas as suas obras se verifica, em maior ou menor proporção, o uso das virtualidades que o sistema linguístico oferece aos seus falantes, o subcapítulo referente aos aspectos sociolinguísticos da criação lexical e seu pendor para os neologismos, a nosso ver, está plenamente justificado.

Só nos resta observar que, enquanto cultura, língua e sociedade interagem continuamente, sob configurações estabelecidas na incessante e complexa construção e reconstrução do mundo, o olhar do linguista busca compreender e explicar essa elaboração e reelaboração que tem no léxico testemunho perene. Ao linguista é reservada, sobretudo, a surpresa das representações que observa.

3.2 Etnoterminologia: fronteiras

Preliminarmente, devemos nos situar na perspectiva da Etnossemiótica, um domínio que se constituiu a partir da reunião de etnólogos e semioticistas interessados não apenas na descrição das línguas exóticas, mas também em suas particularidades semânticas:

É ao domínio coberto pela etnossemiótica que cabe o mérito de ter concebido, inaugurado e fundamentado ao lado das descrições paradigmáticas que são as etnotaxionomias, as análises sintagmáticas que dizem respeito aos diferentes gêneros da literatura étnica, tais como as narrativas folclóricas (V. Propp) e míticas (G. Dumézil, C. Lévi- Strauss), e graças às quais se renovou a problemática do discurso literário. ${ }^{92}$

Em “A Morfologia dos Contos de Fadas”, publicado em 1928, Vladimir Propp, teórico russo, estabeleceu os elementos narrativos básicos, por ele identificados nos contos folclóricos russos e que fundamentalmente, ainda que de maneira flexível, fariam parte desses contos ${ }^{93}$. A Georges Dumézil deve-se:

\footnotetext{
${ }^{92}$ GREIMAS.A. J.; COURTÉS, J. Dicionário de Semiótica, São Paulo, Contexto, 2008, p.191, 192.

${ }^{93}$ Narratologia. Disponível em: <http//:pt.wikipedia.org/wiki/Narratologia> Acesso em: 18 de ago. 2011.
} 
[...] a construção de um modelo teórico de descrição da "ideologia" indo-europeia, enquanto forma de compreensão do mundo, de atribuição de sentido, de manutenção da ordem social, sendo estas, segundo Dumézil, as funções cruciais da dimensão religiosa e mitológica nas sociedades indo-europeias ${ }^{94}$.

Claude Lévi-Strauss se interessou pelo estudo das mitologias, considerando os mitos parte de sistemas mitológicos em transformações, encontrando no estruturalismo linguístico o caminho para compreender as narrativas míticas: a interpretação de um mito está vinculada à análise conjunta de outros mitos que lhe são próximos. Assim considerando, tornou clara sua aproximação da linguística e a influência que o amigo Roman Jakobson e que Noam Chomsky tiveram na construção dos seus postulados. ${ }^{95}$

No domínio coberto pela Etnoterminologia consagra-se o estudo dos universos de discurso etnoliterários, do qual fazem parte:

[...] a literatura oral, literatura popular, literatura de cordel, mitos, lendas, folclore que são preservados, ao longo dos séculos, pela memória coletiva das comunidades e transmitidos de uma geração à outra pelas populações e também os discursos especiais com baixo grau de tecnicidade e cientificidade $[\ldots]^{96}$

A função mítica, a memória social, o conhecimento compartilhado sobre o mundo e a natureza humana, organizado em sistemas de valores e sistemas de crenças que permeiam as preocupações da Etnossemiótica, foram incorporados pela Etnoterminologia e são alguns dos diferentes aspectos que permeiam essa subárea da Terminologia.

A Semiótica das Culturas, "elaborada no mundo natural", "feito de natureza e cultura" $^{97}$, tendo na ciência da interpretação sua tendência recente, ${ }^{98}$ tem como principais eixos o estudo da visão de mundo, a delimitação espacial e determinação histórica, bem como

\footnotetext{
${ }^{94}$ Georges Dumézil. Disponível em: $<$ http://www.infopedia.pt/\$georges-dumezil $>$ Acesso em: 18 de ago. 2011.

${ }^{95}$ HTTP://scielo.br/scielo.php?script=sci arttex\&=S0102-69092006000100010, Claude Lévi-Strauss, quatro décadas depois:as mitológicas. Acesso em 18 ago. 2011.

${ }^{96}$ PAIS, Cidmar Teodoro.; BARBOSA, Maria Aparecida. Da análise de aspectos semânticos e lexicais dos discursos etnoliterários à proposição de uma etnoterminologia. Matraga, Rio de Janeiro, vo . 16, p. 79-100, 2004

${ }^{97}$ GREIMAS, A. J.; COURTÉS, J. Dicionário de Semiótica, São Paulo, Contexto, 2008, p.324

${ }^{98}$ PAIS, Cidmar Teodoro. Considerações sobre a Semiótica das Culturas: uma Ciência da Interpretação: Inserção Cultural, Transcodificações Transculturais. In: Acta Semiotica et Lingvistica, v.11, São Paulo, Terceira Margem, 2007, p.149
} 
os sistemas de valores dos grupos humanos, e também contribui na análise e se inscreve como um dos suportes da Etnoterminologia, na medida em que examina o homem inserido e integrado, em diferentes graus, em determinada sociedade, compatível com seu conhecimento e competência culturais.

Outra vertente de grande importância que aqui interage contempla o conjunto de processos semióticos, a Semiótica Verbal que estuda os sistemas de significação linguísticos, o das línguas naturais, suas microssemióticas e os seus discursos que são, em essência, de acordo com Pais, de dois tipos: figurativos e não-figurativos. Os discursos figurativos subdividem-se em discursos literários e discursos etnoliterários, sendo este último o objeto fundamental da nossa análise. ${ }^{99}$

Como já sabemos, o corpus da nossa pesquisa abrange uma grande obra literária, uma das mais importantes da nossa língua. Entretanto, é no universo semiótico desse discurso literário por natureza que analisaremos as características do discurso etnoliterário de G. Rosa pois, para Greimas e Courtés, “os discursos ocorrência nunca se apresentam em estado puro". 100

De acordo com os mesmos autores, entre a semiótica etnoliterária e a semiótica literária não há como estabelecer categoricamente a fronteira que as separa e os autores nos apresentam alguns critérios principais que podem distingui-las:

a) a ausência (ou presença implícita) do código semântico no discurso etnoliterário, que se opõe à sua explicitação e à sua integração no discurso etnoliterário; $b$ ) a manutenção de uma distância - como em outras semióticas - entre a produção do discurso e a sua execução, própria da etnoliteratura; $c$ ) a importância das estruturas da enunciação enunciada própria do discurso literário (podendo chegar inclusive à "destruição" do relato), se opõe ao apagamento do enunciador (e de suas marcas) no discurso etnoliterário. Todas essas diferenças, porém, são apenas graduais e questionam a existência de organizações narrativas e discursivas comuns $[\ldots]^{101}$

Por outro lado, os mesmos autores identificam a etnoliteratura como sendo própria das comunidades arcaicas e também das sociedades agrárias relativamente fechadas.

\footnotetext{
${ }^{99}$ PAIS, Cidmar Teodoro. Elementos para uma tipologia de discursos semióticos, Revista Brasileira de Linguística. São Paulo, SBPL, Livraria Duas Cidades, 1982, v.6, nº 1. p.53

${ }^{100}$ GREIMAS, A. J.; COURTÉS, J. Dicionário de Semiótica, São Paulo, Contexto, 2008, p.210

${ }^{101}$ Ibid., p.192.
} 
Ao adentrarmos no universo semiótico verbal rosiano, há que precisarmos que estamos penetrando em um mundo semioticamente construído em uma combinatória de sistemas semióticos, uma vez que a "semiótica geral autoriza tratar como discurso ou texto os encadeamentos sintáticos não linguísticos (gestuais, somáticos, etc)". 102

A semiótica não-verbal também exerce papel de cooperação nessa construção, e o conjunto de semióticas engendrado na comunidade sócio-linguístico-cultural do sertanejo dos gerais, delimitado no tempo e circunscrito no espaço, constitui a macrossemiótica rosiana.

Enquanto expressão sociocultural, a língua é a mais importante forma de representação de um contexto, e com os grupos evolui, simbolizando suas realidades. É o elo histórico do passado e presente que une todo homem às suas tradições remotas e às suas origens. Desse modo, as diferentes formas de conceber a realidade, que linguisticamente sustentam as manifestações socioculturais, identificam cada grupo humano, afastando-os em especificidades profundas e aproximando-os em identidades não menos importantes, registrando perenemente os valores, crenças e práticas no tempo e espaço em que se produzem o saber e o saber-fazer.

Os grupos humanos atuam sobre o universo antropocultural, e assim, a realidade fenomênica, recortada culturalmente, é cristalizada em signos que formam os diferentes sistemas de significação. A substância semântica virtual é a mesma existente para todos os grupos linguísticos, que se encarregam de formalizar e estruturar seus códigos, para, através deles, analisar, representar e comunicar o mundo, num processo duplo de recepção, armazenagem e recuperação da informação entre seus membros. A ideologia refletida nos códigos e sistemas semióticos constitui um mundo semioticamente construído. A riqueza dos seus conteúdos linguísticos, a serem escolhidos e transformados sem cessar no fazer social, é sustentada dialeticamente entre forças contrárias e complementares, que são sua fonte de continuidade e a força de sua conservação, processo que assegura a continuidade histórica, a intercompreensão e a mudança que permite a renovação da língua.

Assim posto, verificamos quão pertinente é a afirmação de Barbosa segundo a qual "língua, sociedade e cultura são indissociáveis, interagem continuamente, constituem na verdade, um único processo complexo. A separação, por eventuais exigências da análise científica, não deixa de ser uma mutilação, conquanto metodológica." 103

\footnotetext{
${ }^{102}$ GREIMAS, A. J.; COURTÉS, J. Dicionário de Semiótica, São Paulo, Contexto, 2008, p.192.

${ }^{103}$ BARBOSA, Maria Aparecida. Léxico, Produção e Criatividade. São Paulo: Editora Plêiade. 1996, p. 158.
} 
O sistema linguístico renova-se constantemente e novos signos são criados, alguns sofrem modificações e outros se mantêm em um processo de mudança ou conservação que sustenta a continuidade de uma língua.

Ao dar forma linguística aos avanços científicos e tecnológicos, às transformações dos costumes de uma sociedade ou mesmo a um novo fato sociocultural circunscrito a determinada região, um indivíduo ou uma comunidade linguística podem criar novos termos ou atribuir novos significados para termos já existentes.

Os discursos ou textos que permitem compreender e preservar o processo histórico e cultural sustentam-se na tensão dialética entre duas tipologias de discursos: o das linguagens de especialidades de um lado ou os discursos ditos não literários e os literários ou ficcionais de outro.

A zona de intersecção entre os estudos dos universos de discursos literários e os das linguagens de especialidades ou terminologias é ocupada pela Etnoterminologia.

Definidos os objetos de estudo, métodos e campos de atuação da Lexicologia e da Terminologia, disciplinas das ciências da linguagem, portadoras de um aparentemente mesmo objeto de estudo, Maria Aparecida Barbosa distinguiu a existência, no domínio da Terminologia, de uma subárea, a qual denominou Etnoterminologia. Pesquisas da autora, de há muito vêm delineando a Etnoterminologia e a Terminologia Aplicada, enquanto subáreas da Terminologia, e culminaram com a recente proposta da pesquisadora de formalização da disciplina científica, a Etnoterminologia e suas decorrências em Terminologia Aplicada.

Em meio à vasta produção voltada para a Lexicologia e para a Terminologia, este novo campo de estudos nos aproxima de uma "[...] tênue fronteira existente entre o termo técnico-científico e o vocábulo da língua geral [...]"104, porém, ultrapassada essa fronteira, verificamos quão densa e complexa é sua substância.

O vocábulo-termo manifesta-se nos discursos etnoliterários, e congrega ambas as funções restritas ao vocábulo ou termo, nos universos de discursos e nos discursos ocorrência, seus campos de realização.

Maria Aparecida Barbosa apresenta-nos a unidade lexical que "subsume" duas funções, nos mesmos discursos ocorrência. De acordo com Barbosa, o "vocábulo-termo" reúne “[...] qualidades das línguas especializadas e da linguagem literária, de maneira a

104 BARBOSA, Maria Aparecida. Etno-terminologia e Terminologia Aplicada: objeto de estudo, campo de atuação. In: ISQUERDO, Aparecida Negri; ALVES, Ieda Maria. (Org.). As ciências do léxico. Lexicologia, Lexicografia. Terminologia. $1^{\text {a }}$. ed. Campo Grande. MS: , 2007, v. 3, p. 433 
preservar um valor semântico e social, e constituir simultaneamente, documentos do processo histórico e cultural [...]". ${ }^{105}$

A Lexicologia estuda o universo de todas as palavras geradoras e reflexos que são de recortes culturais, do ponto de vista de sua estruturação, funcionamento e mudança e como estudo científico do léxico tem contribuído para delimitar os vocabulários específicos de uma ciência ou área. O léxico é constituído de vocabulários, que se realizam em atos de fala, em diferentes universos de discursos.

A percepção de um fato é representada por determinada forma linguística, por um processo de denominação, ou seja, ao fato conceptual atribui-se uma forma sígnica. Tal é o percurso da investigação científica da Terminologia, que tem inicio no recorte técnico científico em direção à denominação, pelo processo ao qual damos o nome de onomasiológico.

Portanto, o recorte do real operado pelo léxico em diferentes e múltiplos contextos evidencia a palavra como objeto de estudo de diferentes campos do saber e da experiência humanos. A palavra agrupa-se a diferentes universos léxicos, de modo a constituir um conjunto de termos específicos ou especializados em cada um deles.

$\mathrm{O}$ universo de discurso, "conjunto não-finito, ou que tende ad infinitum, de todos os discursos manifestados que apresentam determinadas características e constantes, assim como determinadas coerções, suscetiveis de configurar uma norma”"106, contém elementos com significação específica, refletindo diferentes aspectos de conceptualização apreendida por diferentes grupos sociais. Seu uso pressupõe conhecimento do espaço histórico e social onde se deu a configuração da conceptualização. Na maioria das vezes há que se fazer parte do grupo, apreender como a forma de conceptualizar a realidade se reflete nas palavras, e debruçarmo-nos sobre o significado dos termos para poder compreendê-los e usá-los acertadamente em seu domínio. Estas palavras se consubstanciam em unidades padrão do vocabulário dos vários universos de discursos possíveis.

\footnotetext{
${ }^{105}$ BARBOSA, Maria Aparecida. Etno-terminologia e Terminologia Aplicada: objeto de estudo, campo de atuação. In: ISQUERDO, Aparecida Negri; ALVES, Ieda Maria.. (Org.). As ciências do léxico. Lexicologia, Lexicografia. Terminologia. $1^{\text {a }}$. ed. Campo Grande MS: , 2007, v. 3, p. 434.

${ }^{106}$ PAIS, C. T. “Aspectos de uma tipologia de discursos”. Revista Brasileira de Linguística, v.7, no . 1. São Paulo, Global Editora, 1984, p.44.
} 
3.2.1 A unidade mínima de significação da Etnoterminologia: o vocábulo- termo

As unidades lexicais no nível de sistema são plurifuncionais e estão disponíveis para atualização como vocábulo ou termo e dependem de uma norma discursiva ou de um texto ocorrência, que definirão sua função. Portanto, relembrando Hjelmslev, a relação entre os vocábulo e termo é [e...e] em nível de uma norma de discurso, e essa relação é [ou...ou], em nível de uma norma ou de um discurso ocorrência ${ }^{107}$. Os vocábulos-termo são por sua vez, unidades do discurso etnoliterário que configuram uma axiologia, e são por este motivo, símbolos dos temas aos quais se referem:

\footnotetext{
Essas unidades lexicais têm sememas muito especializados, construídos com semas específicos do domínio em questão, provenientes das narrativas, cristalizados, de modo a tornar-se verdadeiros símbolos dos temas envolvidos" São dotados os vocábulos-termos de duplo estatuto, na medida em que são unidades multifuncionais e multissignificativas. ${ }^{108}$
}

Cada vocábulo-termo é uma unidade de conhecimento com forte marca de conceptualização da realidade fenomênica composta de duas faces distintas e indissociáveis: a face vocábulo, uma das suas funções, que pertence à língua geral e porta elementos paradigmáticos, referenciais e simbólicos, e sua face termo, das linguagens terminológicas, sua outra função, que porta verdades gerais e universais, registros que são do conhecimento acumulado sobre o mundo, sobre a natureza humana, e a axiologia de um povo. É este o modelo que nos permite visualizar em semântica profunda a tensão vocábulo-termo:

\footnotetext{
${ }^{107}$ BARBOSA, Maria Aparecida. Etno-terminologia e Terminologia Aplicada: objeto de estudo, campo de atuação. In: ISQUERDO, Aparecida Negri; ALVES, Ieda Maria.. (Org.). As ciências do léxico. Lexicologia, Lexicografia. Terminologia. $1^{\text {a }}$. ed. Campo Grande MS: , 2007, v. 3, p. 435.

${ }^{108}$ Id., Cultura Popular Amazônica em Etnoterminologia. Anais da 61 ${ }^{a}$ Reunião da SBPC - Manaus. A. M. julho, 2009.
} 
A tensão vocábulo - termo

unidade léxica etnoliterária

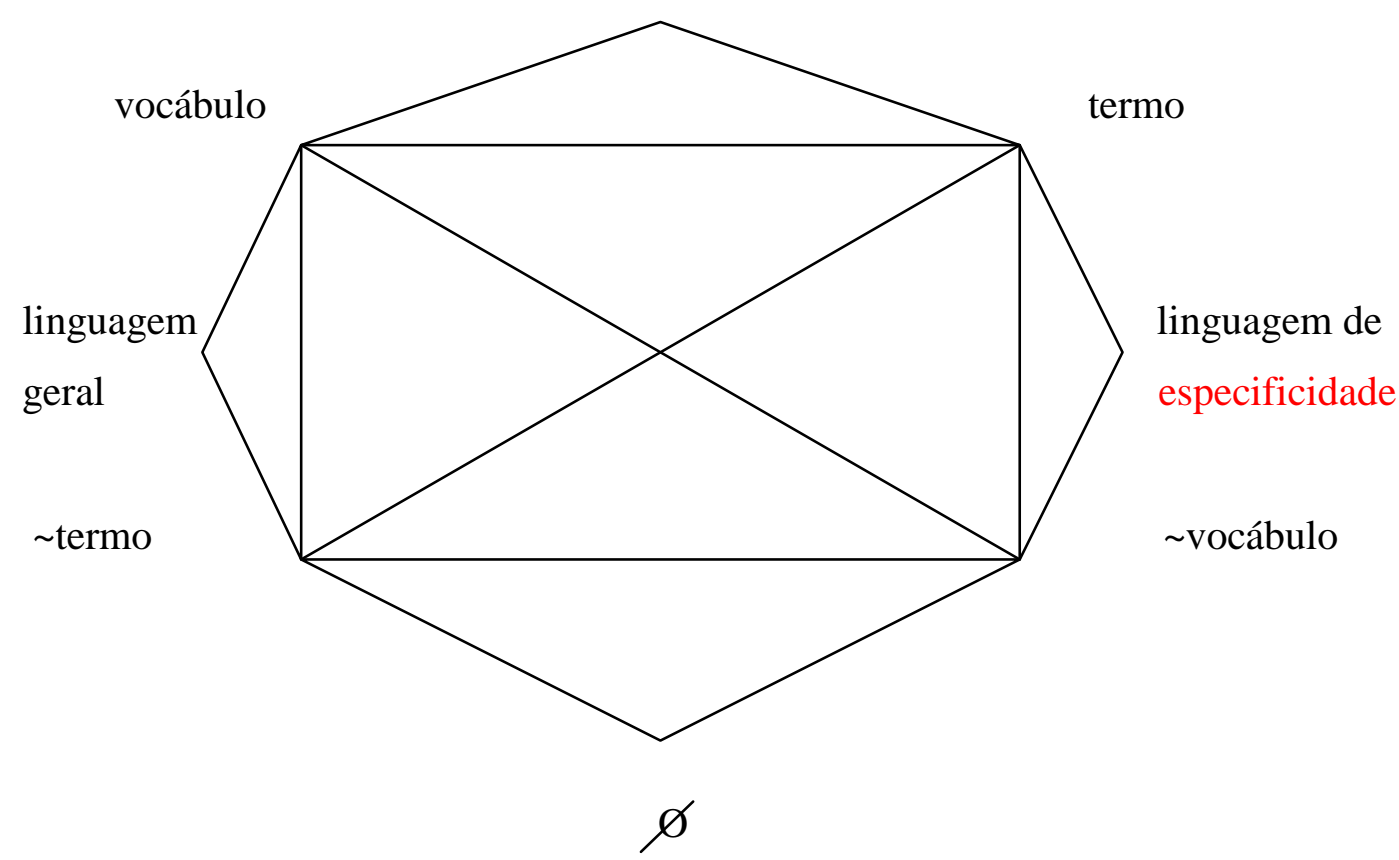

Muito embora a densidade terminológica possa não ser na maioria das vezes a característica principal do vocábulo-termo, já podemos observar que o grau de informatividade e densidade semântica são notáveis nas unidades lexicais que nos propusemos a analisar, como veremos em nossa ficha etnoterminológica. No entanto, são os entornos discursivos que situarão os vocábulos-termos no mais elevado patamar de densidade terminológica ou em um baixo grau de especialidade ${ }^{109}$.

Essa variação funcional, que realça a disponibilidade do vocábulo-termo de sujeitar-se às regras e processos da língua geral, é determinada pelos universos de discursos e pelos discursos manifestados.

A Etnoterminologia é o campo de estudos consagrado ao domínio etnoliterário, cuja unidade de significação amalgama na unidade lexical o estatuto de vocábulo e termo simultaneamente, com significado exclusivo, ao mesmo tempo próprio às linguagens de especialidade e literária também. As qualidades inerentes à linguagem de especialidade e à

\footnotetext{
${ }^{109}$ BARBOSA, Maria Aparecida. Cultura Popular Amazônica em Etnoterminologia. Anais da $61^{\text {a }}$ Reunião Anual da SBPC, Manaus, AM, julho, 2009.
} 
linguagem literária do universo de discurso etnoliterário conferem, ao vocábulo-termo, o valor semântico-social e documental do processo histórico de uma cultura ${ }^{110}$.

\subsubsection{Das modalizações discursivas na Etnoterminologia}

Pais e Barbosa confrontam a formalização e distinção dos discursos etnoliterários em relação aos discursos literários e científicos, a partir da tipologia dos discursos e dos universos de discursos. ${ }^{111}$

A tipologia discursiva que caracteriza e separa os discursos literários (figurativos por excelência) dos discursos sociais não literários (não-figurativos), nos deixa entrever a zona fluida, de transição, na qual se situam os discursos etnoliterários passíveis de descrição complementar tipológico-discursiva, distintos que são em sua especificidade dos demais.

Nos modos de existência e produção dos discursos literários (dentre outros critérios de equivalência), a produção do efeito de verdade não é considerada, e sua função estética e a modalidade poder-fazer-crer são determinantes para sua eficácia.

Os discursos tecnológicos e os científicos, especificamente, estão assentados, quanto às estruturas de poder, no poder-saber-fazer e poder-fazer-saber respectivamente.

Os discursos etnoliterários, por sua vez, são percebidos pelos sujeitos como portadores de verdades gerais e universais, e se ocupam dos sistemas de valores (poder-fazer-saber) e sistemas de crenças (poder-fazer-crer) que, por sua vez, determinam pensamentos e condutas (poder-saber-fazer), e formas de ver o mundo e o ser humano (poder-fazer-dever). Verifica-se, facilmente, portanto, que as modalidades nas quais se sustentam interagem com maior complexidade do que nos outros discursos.

As várias modalidades dialeticamente estruturadas no discurso etnoliterário comprovam que esse gênero textual abarca não apenas as características dos discursos literários, no que concerne à sua tipologia, mas também as dos discursos não literários, dentre

\footnotetext{
${ }^{110}$ BARBOSA, Maria Aparecida. Etno-terminologia e Terminologia Aplicada: objeto de estudo, campo de atuação. In: ISQUERDO, Aparecida Negri; ALVES, Ieda Maria.. (Org.). As ciências do léxico. Lexicologia, Lexicografia. Terminologia. $1^{\text {a. }}$ ed. Campo Grande MS: , 2007, v. 3, p. 441.

${ }^{111}$ PAIS, Cidmar Teodoro.; BARBOSA, Maria Aparecida. Da análise de aspectos semânticos e lexicais dos discursos etnoliterários à proposição de uma etnoterminologia. Matraga, Rio de Janeiro, v. 16, p. 79-100, 2004.
} 
os quais nos interessa particularmente a Terminologia em suas semelhanças e diferenças com a Etnoterminologia.

Servem-se da Terminologia, enquanto linguagem de especialidade, todos os discursos sociais não literários, a saber, e não exaustivamente, os discursos científicos, jurídicos e políticos, das áreas especificas do saber, como a química e a economia, por exemplo. À língua comum pertencem os demais universos de discurso, muito embora se interpenetrem interferindo, conforme Pais, uns sobre os outros, "já que um único e mesmo discurso manifestado pode pertencer simultaneamente a mais de um universo de discurso, como, por exemplo, o científico/pedagógico". ${ }^{112}$

Tendo sido reconhecido o texto como o habitat natural das terminologias, pois para Cabré "O habitat natural da unidade terminológica é o texto", e com sua proposta de abordagem do termo in vivo, fica reconhecido que o termo não é em si mesmo um termo, mas uma unidade léxica que está em função de termo. É relevante, portanto, a compreensão da palavra vinculada ao seu universo de discurso, à expressão particular de um grupo de falantes, que reúne conhecimentos distintos a diferentes áreas técnicas e científicas e seu modo especial de operar o léxico da língua geral, ou seja, em uma linguagem de especialidade.

Tal compreensão nos remete ao processo de deslocamento da palavra conforme seu uso: a terminologização é o processo que confere ao vocábulo da língua geral o estatuto de termo, quando utilizado em linguagens de especialidades, e o processo inverso, vocabularização, acontece quando o termo passa a integrar o vocabulário dos falantes da língua geral.

No plano conceptual reside a forma final do processo de atribuição e supressão de valores, funções e traços a partir da projeção do homem sobre os fatos da natureza e da sociedade que convergem para determinada visão de mundo. Conceber determinada realidade significa para o homem em particular, ou para um grupo, tecer seu contexto sociocultural específico, cuja origem se desenvolve dinamicamente no tempo e no espaço.

É o processo de elaboração cultural que gera por sua vez o universo antropocultural, com seu sistema próprio de significações.

A Etnoterminologia capta o modo de existência das palavras que nem sempre se explicam para aqueles que não pertencem aos domínios que as refletem. Estuda a unidade léxica (vocábulo-termo), que representa um grupo de falantes linguística e socialmente

\footnotetext{
${ }^{112}$ PAIS, Cidmar Teodoro. Aspectos de uma tipologia de discurso. Revista Brasileira de linguística. São Paulo: Plêiade; SBPC, v.7, nº. 1, p.44.
} 
definido, histórica e geograficamente delimitado, grupo este que detém os valores conceptuais próprios de uma realidade e atribui valores semânticos à forma conservadora como vê o mundo, o que exige do interlocutor imersão total nesse grupo social, ao lado do homem que o habita. Ou seja, para usar o vocábulo-termo é preciso conhecer a axiologia do grupo em que teve origem, do grupo que conceptualizou seus signos-símbolos.

A Etnoterminologia está intimamente associada ao sentido de etnia e etnicidade/ etnismo na formação social e cultural de um grupo, e às interferências históricas e geográficas que subordinam o processo de conceptualização dos seus sujeitos. Suas formas para denominar portam valor documental, fruto do contato com a realidade e visão de mundo, da axiologia que permeia suas relações. Enquanto veículo da herança da cultura popular, amealhada ao longo do tempo, refletem valores, usos, costumes, crenças, hábitos de caráter fundamental, porém abstratos, e modulam a maneira de pensar, sentir e viver de um grupo.

A natureza especializada do vocábulo-termo aflora vínculos outros que não o de raça ou limites geográficos, mas preponderantemente das relações sociais de parentesco remoto, o sentimento de pertencimento ao grupo, de fatores culturais como a nacionalidade e as tradições com características de etnicidade, que, como afirmou Saussure, estão na base da unidade linguística, sendo verdadeiramente a unidade essencial, a que chamou de etnismo. ${ }^{113}$

As especificidades sociais e culturais definíveis como modelo de ação e interação entre membros de um grupo consubstanciam-se em valores apreensíveis em modelos que se refletem na articulação linguística interna, possibilitando-nos observar nos discursos etnoliterários que os tipos humanos são suportes de grandes temas universais, que se enfrentam dialeticamente nas oposições amor x morte; vida x morte; bem x mal; riqueza x miséria; fidelidade x traição; Deus x demônio; alma x amor; poder x fraqueza. Esses temas estão identificados dentre os temas principais de Grande Sertão, do conhecimento de todos, que são, além do tema sertão: Deus, diabo e amor .

É importante também examinarmos a preocupação estética ligada à face literária do discurso etnoliterário em sua singularidade expressiva, alternando-se nas esferas da poesia de rima fácil e da prosa volteada, cantadas tanto pelos poetas populares como pelos contadores mais velhos da família ou do povo.

\footnotetext{
${ }^{113}$ SAUSSURE, Ferdinand de. Curso de Linguística Geral. São Paulo, Editora Cultrix, 1971. p.261.
} 


\subsection{A formação do conceito nos discursos etnoliterários}

As relações entre expansão do acervo léxico e inovação lexical de um lado, e a visão social e cultural inerentes aos diferentes domínios da experiência humana, de outro, estão sujeitas à interação dos aspectos linguísticos, sociais e culturais. O modo de percepção dos dados no universo antropocultural, passível de representação, reafirma as especificidades e multiplicidades conceptuais ao se formalizarem infinitamente no universo léxico, produzindo grandezas-signos inéditas, que testemunham as mudanças dos sistemas sociais e culturais, conforme já analisamos em nossa introdução e em nossos fundamentos teóricos.

O percurso gerativo da enunciação de codificação e decodificação é estruturado em momentos, ao longo dos quais é descrito cada nível do seu processo global, cujo produto final é o texto manifestado que sustenta o processo permanente de produção de significação e de unidades léxicas neológicas: ou seja, trata-se de um processo que se dá em ciclos, movimento que atesta a vitalidade linguística com a introdução de unidades lexicais que, como nos ensinou Ieda Maria Alves, recicla os elementos disponíveis. É o processo preferencial este, de atribuição de novos significados aos significantes já existentes.

A unidade léxica neológica, o novo lexema, é entendido como a configuração da percepção do fato virtual, "la mise en lexème", anterior ao processo de conceptualização, momento no qual se reafirma o princípio universal de formação, que parte do continuum amorfo. $^{114}$

A apreensão da realidade se dá em três níveis: temos no primeiro nível a percepção dos fatos reais, dos objetos do mundo: o início desse percurso (percepção biológica e cultural universal filtrada) dá-se na realidade fenomênica em que os fatos naturais estruturáveis e recortes culturais preexistentes (biofatos, sociofatos, psicofatos e manufatos) são percebidos e, uma vez apreendidos pelo homem, convertem-se em substâncias estruturadas em variados recortes semânticos, fonéticos e fonológicos, gerando reflexos culturais, contidos na base lexical da palavra, reveladora da axiologia de um grupo ou de um indivíduo. Tais fatos estão disponíveis no universo natural (semiótica natural) como virtualidades, hipóteses a serem trabalhadas a partir de uma massa amorfa, cuja significação depende da ação humana; no segundo nível temos a conceptualização, construção do protótipo: temos o início do processo

\footnotetext{
${ }^{114}$ HJELMSLEV, Louis. Prolégomènes a une theorie du langage. Les Editions de minuit. Paris, 1968, p.71-75
} 
de conceptualização, pré-linguístico e pré-semiótico, que é a projeção do homem sobre os fatos da natureza que ganham forma (fato formado), a partir da seleção e escolha dos traços que farão parte do fato em si, configurando um conceito. Este processo é elaborado em três estágios que se originam na percepção dos objetos do mundo in potentia: das latências, estágio potencial enquanto substância de conteúdo (Hjelmslev) estruturável em traços distintivos semânticos apreensíveis; das saliências, em que as características estruturáveis se destacam na semiótica natural; e das pregnâncias, em que o fato se configura, conforme Pottier, a partir de uma escolha do enunciador individual ou coletivo, dos traços que produzem o conceito do fato em si. No terceiro nível - da semiologização, semiotização - o conceptus virtual transforma-se em modelo mental efetivamente produzido, e em designata, recortes culturais. Trata-se do processo de elaboração cultural exercido pelo homem (semiótica humana), cuja intervenção gera o universo antropocultural, conceptus < - > designata. Na semiologização (de acordo com Rastier), as noções ou conjuntos noêmicos, os atributos dos conjuntos noêmicos são convertidos em atributos semânticos pressemióticos, transsemióticos, e de ordenamento dos campos semânticos. Na semiotização o nível cognitivo passa ao semiótico propriamente dito.

"Esses três momentos - da percepção, do início e do fim da conceptualização constituem, assim, o próprio percurso da cognição, entendido como a apreensão e construção de uma "visão de mundo", formação do fato estruturável, como registra Barbosa, ao estudar as unidades padrão do plano cognitivo e semiótico. ${ }^{115}$ É a própria construção do conceito nos discursos técnico-científicos, nos discursos literários e nos discursos sociais não literários. Reúne três tipos de traços que constituem um mínimo semântico, ou seja, um núcleo noêmico.

\footnotetext{
De acordo com Paes, "essa produção, sempre reiniciada e reiterada em cada enunciação, conduz, por geração, acumulação e transformação, à construção de um 'léxico' conceptual - protótipos Dubois, (1990; 29-100) e conceptus (Rastier, 1991; 73-114) - e de uma 'sintaxe' conceptual, ou, noutras palavras, de um metassistema conceptual disponível para atualização em qualquer semiótica-objeto de determinada cultura e sociedade, caracterizando-se como uma pancronia no sentido amplo (funcionamento e mudança)."116
}

\footnotetext{
${ }^{115}$ BARBOSA, Maria Aparecida. A construção do conceito nos discursos técnico-científicos, nos discursos literários e nos discursos sociais não-literários. In: Revista Brasileira de Linguística, v.11, Editora Plêiade, São Paulo, 2001, p.33

${ }^{116}$ PAIS, Cidmar Teodoro. Conceptualização, denominação, designação: relações. In: Revista de Linguística, São Paulo, v.9, 1997, p.225
} 
O último momento que nos interessa diante de nossos propósitos, a lexematização ou terminologização, dependendo do universo de discurso, integra o conceito formado ao signo linguístico, momento da denominação. Nesse momento, "o metassistema lexemático ou terminológico autoriza a atualização da lexia num discurso concretamente realizado."117 Passa-se ao nível semiótico, pois ele corresponde à conversão do conceito em grandeza signo. Ao denominar, o enunciador realiza um processo que organiza / reorganiza o sistema linguístico e o metassistema conceptual: o sujeito enunciador não apenas cria ao denominar, como também reutiliza os vocábulos a cada ato de fala.

\begin{abstract}
A lexemização aqui é entendida como "la mise en lexème", e terminologização como "la mise en terme", ou seja, a configuração do conceito em grandeza signo, no próprio ato de instaurar a significação. Dessa forma, o metassistema conceptual, o mesmo para todas as semióticas objeto de uma cultura, produz conjuntos de semas conceptuais que desempenham o papel de matrizes sígnicas, para diferentes sistemas semióticos de uma mesma cultura, de uma macrossemiótica, em suma, por meio dos processos de semiologização, lexemização, terminologização, e semiotização" 118
\end{abstract}

Entre a cognição e a semiose, etapas da enunciação, o processo de enfatizar seja o conceito stricto sensu (subconjunto de traços que servem à conceptualização da semiótica natural), seja o metaconceptus, (subconjunto de traços semântico-conceptuais culturais que produzem simultaneamente uma modificação do recorte cultural, própria de uma reconstrução particular do mundo semioticamente construído), seja o metametaconceptus (subconjunto de traços modalizadores, manipulatórios, em busca da eficácia discursiva) existe uma relação dialética de presentificação de traços já existentes no sistema, e da incorporação de novos traços. Essas etapas levam em conta as circunstâncias da enunciação e do enunciado, e se constituem em uma escolha do sujeito enunciador. Em cada universo de discurso, dos quais se extraem os traços conceptuais, o processo de engendramento do conceito ao lado de outras marcas são caracterizadores importantes desses discursos.

Os dois processos de criação do conceito são:

\footnotetext{
${ }^{117}$ BARBOSA, Maria Aparecida. Da formação do Conceptus à Estruturação semântica Lexical. Boletim da Associação Brasileira de Linguística, v.26, Fortaleza, 2001, p.153

${ }^{118}$ Ibid. , p. 153
} 
A) modus operandi, que corresponde ao processo de criação do conceito na instância do discurso em atualização. Sua construção assume características semânticas, sintáticas, semióticas, pragmáticas diversas, seja em linguagens específicas, ou nas linguagens literárias ou não literárias.

O discurso literário enfatiza o metaconceptus, que é o subconjunto dos traços semântico-conceptuais culturais, produzindo simultaneamente uma modificação do recorte cultural, própria de uma reconstrução particular do mundo semioticamente construído. $^{119}$

As diferenças nos universos de discursos são estabelecidas nas relações entre o conceito no nível semântico-cognitivo e a tematização e figurativização no nível semiótico e no processo de enunciação, pois no percurso gerativo da enunciação geralmente

[...] o conceito é convertido em temas abstratos e em figuras que dão 'corpo', 'espessura' à ideia, acentuando seu efeito de sentido de veredicção ou verossimilhança, entendendo-se por tema a semiotização do conceito, por tematização, o processo de construção de ideias abstratas e, por figurativização, o processo de corporificação dessas ideias."120

O processo de construção do conceito pode, por sua vez, ser vertical, ao partir do fato para o patamar cognitivo, e horizontal, o que ocorre ao desencadear nas relações sintagmáticas de construção paulatina, um conceito, a partir de um recorte conceptual que o autor tem de um fato.

B) lato sensu, que corresponde ao processo de seleção das pregnâncias, que se concluem como produto realizado e dão ênfase tanto aos discursos literários como aos distintos discursos sociais não literários, embora o discurso técnico-científico tenda a ser privilegiado.

No modelo do percurso gerativo de enunciação de codificação e de decodificação podemos observar que as diferenças que se fazem sentir entre campo conceptual, campo lexical e campo semântico, (sendo este o resultado da intersecção do significado das unidades lexicais de um campo lexical), concernem aos tipos e às relações entre os elementos dos

\footnotetext{
${ }^{119}$ BARBOSA, Maria Aparecida. Da formação do Conceptus à Estruturação semântica Lexical. Boletim da Associação Brasileira de Linguística, v. 26, Fortaleza, 2001, p.53

${ }^{120}$ Id., A Construção do Conceito nos Discursos Técnico-Científicos, nos Discursos Literários e nos Discursos Sociais Não-literários. In: Revista Brasileira de Linguística, v. 11. nº . 1, Editora Plêiade, 2001, p.05.
} 
campos e às diferenças nocionais e estruturais, e suas respectivas unidades padrão, que se instalam em diferentes patamares desse percurso.

Por pertencerem a níveis de articulação e de análise distintas, as relações entre eles não são simétricas. O campo lexical pressupõe e contém necessariamente o campo conceptual e o campo semântico que lhe correspondem, e o campo conceptual pode não ter os campos lexicais e semânticos correspondentes.

O campo conceitual, um conjunto de conceitos, é resultado do processo de conceptualização do 'saber sobre o mundo'- pré-linguístico, pré-semiótico, transsemiótico; o campo lexical, um conjunto de lexemas, lexias, vocábulos/termos que têm um núcleo sêmico comum é o resultado do processo de lexemização e o campo semântico, em uma de suas acepções, constitui um conjunto de sememas e resulta da intersecção do significado das lexias de um campo lexical. ${ }^{121}$

Barbosa cita Pais que esclarece o equívoco cometido, à miúde, no emprego dos termos definir/conceituar e definição/conceituação. Conceituar e conceito, definir e definição são termos que embora comumente empregados indistintamente, ou tidos como equivalentes, "são grandezas que têm qualidades conceituais específicas, constituindo, inclusive, unidades padrão e processos de distintos níveis do percurso gerativo da enunciação de codificação e decodificação (Pais, 1993: 562-578)"122.

"Conceituar é o processo de construção de um modelo mental que corresponde a um recorte cultural e em seguida da escolha da estrutura léxica que pode manifestá-lo, o conceito é resultado de uma interpretação de fatos naturais e/ou culturais. Definir é o processo de analisar e descrever o semema linguístico para reconstruir o modelo mental: seu ponto de partida é a estrutura linguística manifestada. Definição é o resultado de uma interpretação de unidades lexicais" ${ }^{\prime 123}$.

Conceito/conceptus corresponde, em sentido amplo, a um modelo 'mental'(Rastier), dialeticamente articulado a um recorte cultural ou designatum. Para Pottier, se constitui em um subconjunto de noemas que, de acordo com Barbosa

\footnotetext{
${ }^{121}$ BARBOSA, Maria Aparecida. A Construção do Conceito nos Discursos Técnico-Científicos, nos Discursos Literários e nos Discursos Sociais Não-literários. In: Revista Brasileira de Linguística, v. 11. N.1, Editora Plêiade, 2001, p.36.

${ }^{122}$ Ibid.,p.32.

${ }^{123}$ BARBOSA. Maria Aparecida. Da formação do Conceptus à Estruturação Semântica Lexical. Boletim da Associação Brasileira de Linguística, v.26, Fortaleza, 2001, p. 154.
} 
[...] apresenta grande complexidade estrutural: um subconjunto de noemas biofísicos ou 'universais', conceito stricto sensu; um subconjunto de traços semânticos conceptuais ideológicos, culturais, metaconceito; um subconjunto de traços semânticos conceptuais ideológicos, intencionais, modalizadores, metametaconceito. ${ }^{124}$

A estrutura do modelo mental - conceptus lato sensu - compreende, de acordo com Barbosa, o conceptus stricto sensu, o metaconceptus, o metametaconceptus e o arquiconceptus. Esquematicamente temos:

\begin{tabular}{|l|l|l|}
\hline $\begin{array}{l}\text { Classes de noemas/ } \\
\text { Conceptus }\end{array}$ & $\begin{array}{l}\text { Caracterização semântico } \\
\text { Conceptual }\end{array}$ & Natureza \\
\hline Noemas universais & $\begin{array}{l}\text { Universais semânticos hiper } \\
\text { profundos }\end{array}$ & $\begin{array}{l}\text { Mecanismos básicos de } \\
\text { cognição }\end{array}$ \\
\hline Conceptus & $\begin{array}{l}\text { Atributos semântico-conceptuais } \\
\text { culturais }\end{array}$ & Pregnâncias/escolhas \\
\hline Metaconceptus & Atributos culturais ideológicos & Pregnâncias/ideologia \\
\hline Metametaconceptus & $\begin{array}{l}\text { Atributos modalizadores } \\
\text { manipulatórios }\end{array}$ & Pregnâncias/ideologias \\
\hline Arquiconceptus & $\begin{array}{l}\text { Atributos multiculturais, } \\
\text { multilinguísticos }\end{array}$ & Intersecção conceptual \\
\hline
\end{tabular}

Campo conceptual do conjunto unitário lato sensu

${ }^{124}$ BARBOSA, Maria Aparecida. Da formação do Conceptus à Estruturação Semântica Lexical. Boletim da Associação Brasileira de Linguística, v.26, Fortaleza, 2001, p. 154 


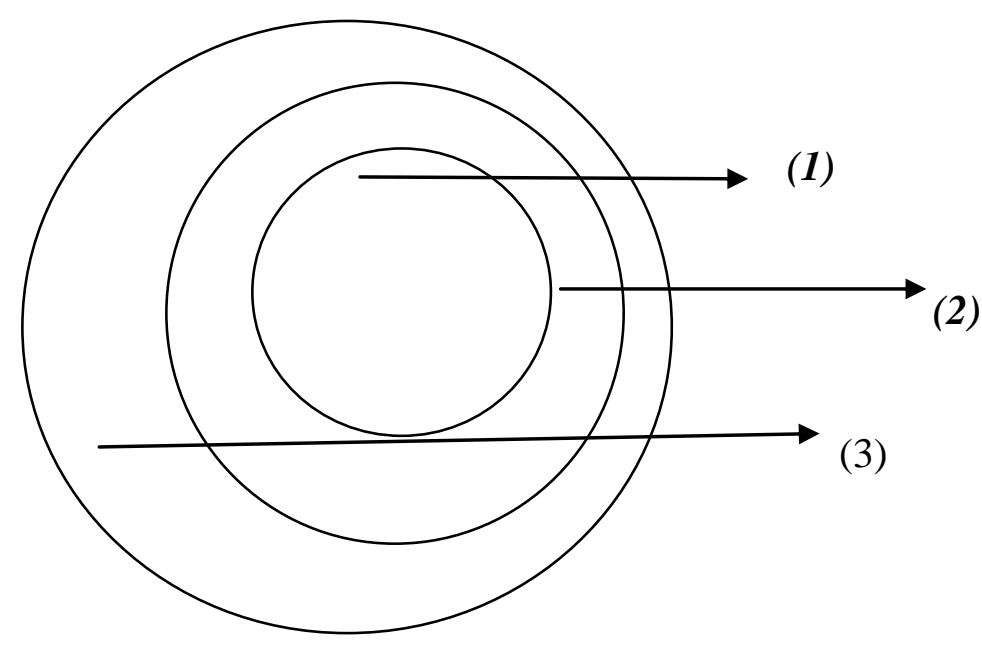

(1) Noemas universais

(2) Noemas ideológicos, culturais

(3) Noemas ideológicos, intencionais, culturais

Esses três subconjuntos contêm noemas característicos, pois os noemas universais garantem a múltipla nomeação; no subconjunto dos noemas ideológicos, culturais, temos os movimentos de redução/ampliação de acordo com aquilo que é importante para cada um e, aos noemas ideológicos corresponde o local de embate.

Ao engendrarmos um conceito, geramos simultaneamente dois outros conceitos, (daí resultante o caráter de campo conceitual de um conceito lato sensu), o seu conceito contrário, e os dois conceitos contraditórios correspondentes, como demonstra a figura:
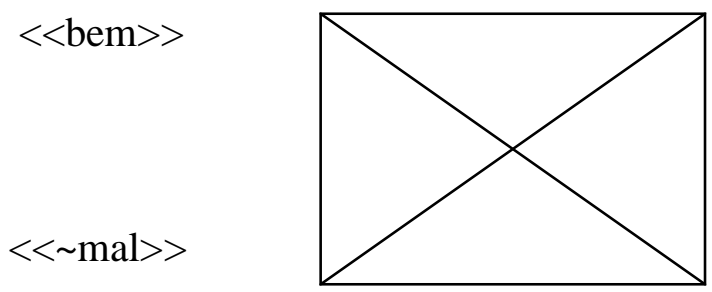

$<<$ mal $>>$

$<<\sim$ bem $>>$

Um conceito liga-se, portanto, necessariamente a outro conceito, pois o raciocínio humano funciona por oposições. Logo, outras conclusões estão implícitas: 
1) o campo conceitual unitário pleno é, e só pode ser, aquele cujo conceito seja constituído de outros três conceitos, 2) o campo conceitual vazio é aquele "que contém conceitos virtuais ainda não engendrados, 3) o campo conceitual múltiplo contém vários conceitos lato sensu explicitados, com um núcleo sêmico comum, apresentando cada um deles, implicitamente, seus conceitos contrários e contraditórios."125

3.4 Aspectos sociolinguísticos da gênese da unidade lexical

O processo e o produto da gênese lexical estão intrinsecamente relacionados a uma nova informação advinda da visão de mundo de cada grupo linguístico, em seus aspectos culturais e sociais. Como consequência deste fato é comum observarmos um novo sema, que integra um lexema já conhecido, em um novo contexto sociocultural, em um universo de discurso que nos é desconhecido, e que transforma nossa experiência linguística.

Barbosa ensina que devemos nos ocupar de três aspectos ao estudarmos a gênese da unidade lexical: 1) o signo linguístico em si mesmo, gerador e reflexo da organização social; 2) o lugar social e o momento histórico da sua criação e a seleção que o homem faz a partir da realidade fenomênica; 3) o processo de desneologização ${ }^{126}$. São aspectos sociolinguísticos diretamente ligados aos atributos não apenas semântico-conceptuais e culturais do novo signo, mas também, aos de natureza ideológica e aos de natureza modalizadora manipulatória.

Embora seja difícil creditar o produto do novo fato semântico a indivíduos em particular, quer tenha origem erudita, fruto da criação de indivíduos particularmente inteligentes, cultos ou bem informados e capazes de utilizar as virtualidades do sistema com desenvoltura, ou, quer se trate de criação popular, resultado anônimo da perspicácia ou invenção aleatória, individual ou de um grupo representante de uma comunidade, esse fato tem origem nos elementos disponíveis a partir da visão humana estabelecida no universo antropocultural.

A possibilidade de instauração de novas significações está presente em uma lacuna do léxico ou, na necessidade de acentuar a expressividade linguística em contextos socioculturais específicos e, de qualquer modo, sempre opera mudanças nesses contextos.

\footnotetext{
${ }^{125}$ BARBOSA, Maria Aparecida. A organização dos patamares conceptual e lexical. In: Boletim da Abralin, v. 26, nº Especial-I, 2001, p.154

${ }^{126}$ Id. , Léxico, Produção e Criatividade. São Paulo: Editora Plêiade, 1996, p.117.
} 
Essas mudanças se fazem a partir da criação individual incidindo sobre um grupo circunscrito ou, a partir da criação de um grupo que afeta toda uma coletividade. Mas não somente. Todo falante-ouvinte reconstitui seu universo lexical no contato com universos de discurso que lhes são estranhos. Isto se deve ao fato de que cada universo de discurso porta marcas que o classifica dentro de um domínio da experiência humana, de acordo com suas normas, passível de classificação em determinado universo de discurso.

Tanto a língua geral, como as linguagens das terminologias ou as linguagens nãoliterárias conservam, quando da utilização do signo em seus limites estritos, caráter monorreferencial e monossignificativo, diferentemente do que ocorre na linguagem literária em que a situação de enunciação é específica, porém, suas marcas são insuficientes para ligála a uma classe de discurso.

A forma e a substância linguísticas geradas pelo processo da criação lexical pressupõem uma tipologia de regras que incidem no percurso dessas criações lexicais desde seu nascimento, o que nos leva a abordar esse fenômeno a partir de pelos menos dois ângulos distintos gerados no meio social: processos e contextos, mas também considerando-se a variação linguística no nascedouro da palavra.

Os processos da criação lexical são de relações intralinguísticas, a saber, os padrões estruturais a serem obedecidos em determinada formação e a relação entre o significante e o (s) significado(s), e de relações extralinguísticas: o ato de fala em si, o seu universo de discurso, a enunciação (contexto da comunicação linguística), a autoria (do indivíduo criador enquanto representante de um grupo ou de um grupo social menor, enquanto representante de um grupo social maior) e ainda, como e com que finalidade foi criada a nova palavra.

Como a criação lexical surge no ato de fala, ou seja, na linguagem verbal oral ou escrita, outras questões emergem: no contexto intralinguístico, o valor da nova palavra e, no contexto extralinguístico a determinação do seu grau de aceitabilidade, a atenção despertada pela novidade léxica, sua eficácia no ato de fala, as circunstâncias históricas e o meio geográfico em que a nova palavra foi produzida, fatores estes de grande importância em todos os domínios da linguagem. ${ }^{127}$

Quanto aos processos intralinguísticos sabemos, de acordo com Guilbert, que são quatro as formas neológicas observadas: neologia fonológica, semântica, sintagmática e alogenética.

${ }^{127}$ BARBOSA, Maria Aparecida. Léxico, Produção e Criatividade. São Paulo: Editora Plêiade, 1996, p.105. 
Trataremos dos atributos semânticos do novo signo linguístico, um fato de grande relevância a ser observado na gênese do vocábulo-termo, e que está presente no âmago do nosso trabalho, muito embora as formações fonológicas e sintagmáticas também pudessem ser objeto de estudo exaustivo.

O significado de um signo linguístico é o mais predisposto a mudanças, pois admite que se enfeixem novos semas sem que tal fato resulte na perda do núcleo semântico original. Para André Martinet, "Só excepcionalmente a designação de novos objectos ou técnicas provoca directamente o aparecimento de novos monemas, a menos, claro, que os termos constituam importações de outra língua"128.

As transformações semânticas são construídas a partir de um signo já existente, ao qual é acrescentado um novo conteúdo semântico, que corresponde a uma nova percepção no universo antropocultural. É na situação de discurso que a substância semântica pode ser enriquecida ao realizar-se um novo recorte dos dados da experiência. O elemento até então virtual, estabelece uma nova função semiótica. Os novos semas podem coexistir ou neutralizar os semas existentes no interior do signo, cuja consequência tende à maior frequência e produtividade, uma vez que a polissemia é a regra linguística, e a monossemia apenas uma possibilidade.

Percebemos que tal formação está particularmente ligada à criação estilística e aos domínios de experiências diferenciados para o falante da língua geral. O resultado é o uso de um significante existente que passa a abrigar novos significados que não apenas aqueles reconhecidos pela maioria dos falantes. A transferência de significados para um novo significante também é fato importante, assim engendrado:

\footnotetext{
Emprego conativo de um lexema, deslocamento de semas do eixo da especificidade semêmica, transposição de um lexema de um universo de discurso para outro, emprego com desfoque semântico de um lexema, a conversão categorial, processos esses sempre situados nas tensões dialéticas sistema / contexto enunciativo e consenso / especificidade. ${ }^{129}$
}

\footnotetext{
${ }^{128}$ MARTINET, André. Elementos de Linguística Geral. Lisboa, Livraria Sá da Costa, 1970, p.178.

${ }^{129}$ BARBOSA, Maria Aparecida. "Da neologia à neologia na literatura", In: As Ciências do Léxico: lexicologia, lexicografia, terminologia”.Editora UFMS-INEP-CPIE, Campo Grande, 2001, p.41
} 
Quanto à variação linguística e suas interferências na criação do novo signo, de acordo com Barbosa ela pode ser de ordem diacrônica, diatópica, diastrática ou disfásica. ${ }^{130}$ São as chamadas variantes diassistemáticas, lexicais ou terminológicas, que correspondem à variação observada no tempo, no lugar geográfico, nos diferentes estratos sociais e nos diferentes lugares semânticos que demarcam traços, atividades, objetivos, métodos e valores dos grupos sociais, bem como suas fontes históricas e míticas. ${ }^{131}$

Sabemos que as possibilidades da língua e do sistema podem ser consideradas como um conjunto de liberdades e também de imposições, as quais o indivíduo domina ou não:

El sistema es sistema de posibilidades, de coordenadas que indican caminos abiertos y caminos cerrados: pero también, y quizá mejor, como conjunto de liberdades, puesto que admite infinitas realizaciones y solo exige que no se afecten las condiciones funcionales del intrumento lingüístico: más bien que imperativa su indole es consultiva"

Ao falante cumpre realizar o sistema, a partir do que é ou não permitido pela norma: “dado que lo que emplea en el hablar no es propia y directamente el sistema, sino formas cada vez nuevas que en el sistema encuentran solo su condición, su molde ideal" "133 A criação das novas formas lexicais está intimamente ligada a essas normas, mas ao seu lado outro fator se manifesta: a conceptualização do universo, advinda da clareza e presteza com que se projeta no léxico de cada grupo, estabelecido no universo antropocultural. São as regras sociais e a visão cultural os limites para que um indivíduo ou um grupo possa, a partir da norma, abstrair o falar concreto, e dele fazer uso para produzir um sem número de novos signos.

Dessa forma, a dinâmica da renovação lexical se faz na interação dos aspectos não apenas sociais e culturais, mas também linguísticos, reflexo das especificidades,

\footnotetext{
${ }^{130}$ BARBOSA, Maria Aparecida. "Da neologia à neologia na literatura”, In: As Ciências do Léxico: lexicologia, lexicografia, terminologia”.Editora UFMS-INEP-CPIE, Campo Grande, 2001, p.33.

${ }^{131}$ Id.,. Léxico, Produção e Criatividade. São Paulo: Editora Pleiade, 1996, p.119.

${ }^{132}$ COSERIU, Eugene. Teoria del Lengage y Linguística General. Madrid: Editorial Gredos, 1973, p.98. (O sistema é um sistema de coordenadas e possibilidades que indicam caminhos abertos e fechados: mas é também e talvez melhor,um conjunto de liberdades, pois admite infinitas realizações e exige somente que não se afetem as condições funcionais do instrumento lingüístico: bem mais que imperativa, sua índole é consultiva). (Tradução nossa)

${ }^{133}$ Ibid., p.99.(pois na fala o sistema não é diretamente empregado, mas as novas formas e cujas condições e molde ideal são encontradas no sistema). (Tradução nossa).
} 
multiplicidades e transformações dos modelos que se formalizam infinitamente no universo léxico produzindo novas grandezas-signos, testemunhando as mudanças dos sistemas sociais e culturais humanos.

Os elementos funcionais do sistema possibilitam as elaborações lexicais de acordo com os modelos do próprio sistema e o resultado pode ser inusitado, seja quanto aos aspectos semânticos, sintáticos ou fonológicos. Permanecer nos limites estritamente prescritivos da norma pode gerar discursos inexpressivos, repletos de elementos comuns, sem fatos linguísticos inéditos, mas que, de modo geral, atendem aos objetivos da comunicação. Ou seja, criar novas formas de expressão ao usar uma língua é sobretudo, tendo conhecimento da norma, ser capaz de adequar-se e expressar-se nos contextos culturais e sociais vários, evocando as diferentes normas geradas no meio em questão.

Coseriu afirma ainda:

\begin{abstract}
En su actividad lingüística, el individuo conoce o no conoce la norma y tiene mayor o menor conciencia del sistema. Al no conocer la norma, se guia por el sistema, pudiendo estar o no estar de acuerdo com la norma (creación analógica); conociéndola, puede repetirla dentro de limites más o menos modestos de expresividad o rechazarla deliberamente e ir más allá de ella, aprovechando las posibilidades que le pone a disposición el sistema. Los grandes creadores de lengua - como Dante, Quevedo, Góngora, Shakespeare, Puskin - rompen conscientemente la norma (que es algo como el "gusto de la época" en el arte)y, sobre todo, utilizan y realizan en el grado más alto las posibilidades del sistema: no es un paradoja, ni una frase hecha, decir que un poeta "ha utilizado todas las posibilidades que le ofrecía la lengua". En este sentido, podemos repetir con Humbold y Croce que, en realidad, no aprendemos una lengua, sino que aprendemos a crear en una lengua, es decir que aprendemos a conocer las directivas, las flechas indicadoras del sistema y los elementos que el sistema nos proporciona como moldes para nuestra expresión inédita ${ }^{134}$."
\end{abstract}

A utilização das potencialidades do sistema depende, portanto, das necessidades sociais e culturais relacionadas não apenas à produção de conhecimentos, mas às informações

\footnotetext{
${ }^{134}$ COSERIU, Eugene. Teoria del Lengage y Linguística General. Madrid: Editorial Gredos, 1973, p.99. Em sua atividade linguística, o indivíduo conhece ou não conhece a norma e tem maior ou menor consciência do sistema. Ao não conhecer a norma, orienta-se pelo sistema, podendo estar ou não de acordo com a norma (criação analógica); conhecendo-a, pode repeti-la dentro dos limites mais ou menos modestos de expressividade ou rechaçá-la deliberadamente ou ultrapassá-la, aproveitando as possibilidades que o sistema põe à sua disposição. Os grandes criadores de língua - como Dante, Quevedo, Cervantes, Gôngora, Shakespeare, Pushkin - rompem conscientemente a norma (que é algo como o "gosto da época" na arte) e, sobretudo, utilizam e realizam no grau mais alto as possibilidades do sistema: não é um paradoxo, nem uma frase feita, dizer que um grande poeta "utilizou todas as possibilidades que a língua lhe oferecia". Neste sentido, podemos repetir com Humbold e Croce que, na realidade, não aprendemos uma língua, isto é, aprendemos as normas que guiam a criação numa língua, aprendemos a conhecer as diretivas, as flechas indicadoras do sistema e os elementos que o sistema nos proporciona como moldes para nossa expressão inédita. (Tradução nossa).
} 
sobre indivíduos, sociedades e agrupamentos humanos que se projetam sobre a língua comum recriando-a, enriquecendo-a e promovendo novas conceptualizações sobre outros membros de outras comunidades linguísticas. Isto faz com que o sistema linguístico renove-se constantemente, novas linguagens e signos sejam criados ou sofram alterações em seu conteúdo semântico, outros signos se tornem antigos, arcaicos, denunciando muitas vezes o tempo decorrido. Este processo de mudança e conservação sustenta a continuidade de uma língua.

A rápida mudança e a ampliação do acervo linguístico, fruto das conquistas humanas em todos os campos do saber, nem sempre nos dão a ideia da evolução como processo ininterrupto ao qual a língua está exposta. Em resumo, bem explicou Martinet:

Tudo conspira para convencer os indivíduos da imobilidade e homogeneidade da língua que praticam: a estabilidade da forma escrita, o conservantismo da língua oficial e literária, a incapacidade em que se encontram de se lembrarem de como falavam dez ou vinte anos antes. ${ }^{135}$

É importante ter em conta que o processo intencional de criação lexical observado, por exemplo, na análise da obra literária de Guimarães Rosa nem sempre se verifica, se bem que é sempre a mesma motivação que leva a gerar novas palavras: o sentimento da sua falta em algum contexto. Para Guilbert, "La forme nouvelle est produite consciemment par le locuteur, afin de traduire un concept ou un aspect non encore exprimé par un mot." ${ }^{, 136}$ Entretanto, a intenção pode ou não permear essa criação.

Enfim, as novas formas lexicais são necessárias para dar forma linguística, em determinado momento histórico, à proposição de um novo conceito, às transformações dos costumes de uma sociedade ou mesmo a um fato sociocultural novo (que pode ser circunscrito a determinada região), para nomear os avanços científicos e tecnológicos da sociedade, e também para atender às intenções estilísticas de um autor.

Para suprir, assim, às suas demandas, um indivíduo, ou uma comunidade linguística cria novos termos ou atribui novos significados para termos já existentes. Para Guilbert " $A$

\footnotetext{
135 MARTINET, André. Elementos de Linguística Geral. Lisboa, Livraria Sá da Costa, 1970, p. 177.

${ }^{136}$ GUILBERT, Louis. Theorie du Neologisme. In: Communication de M. L. Guilbert au XXIV Congrès de I'Association, le 24 juillet 1972, Paris, p.16. (A nova forma é conscientemente produzida pelo locutor, para traduzir um conceito ou um aspecto até então não expresso por uma palavra).
} 
l'origine du terme nouveau se trouve une motivation de manque qui réside dans la nonconformité des termes existent dans le lexique avec le contenu à exprimer",137

Alves assim considera:

\begin{abstract}
Consideramos neológicas as unidades (formalmente novas ou que recebem um novo significado) criadas em um determinado momento histórico-social, que em função de diversas razões (necessidade de nomeação de objetos ou fatos novos, sobretudo) determina essa criação. ${ }^{138}$
\end{abstract}

Guilbert examina a criação lexical como decorrente da disponibilidade das regras de produção existentes num sistema lexical ${ }^{139}$, e nos permite diferenciar entre neologia denominativa e neologia estilística.

A neologia denominativa "reside dans la nécessité de donner un nom à un object, à un concept nouveau. Elle répond seulement au besoin de communiquer une experience nouvelle; elle se inspire non de considerations esthétiques dans son principe, mais du souci d'efficacité." ${ }^{140}$ Nesse caso, a vontade não determina a criação, fundada que é exclusivamente na necessidade imediata de denominação e, podemos dizer, que tem na convenção que nasce dessa necessidade um fator de unidade linguística e social.

A procura constante dos grandes escritores por novas formas de expressão literária pode muito bem ser explicada com as palavras de Mário de Andrade: "Quanto aos neologismos...é certo que o dicionário é insuficiente. Mas não tenho a mínima pretensão de criar palavras novas para o povo e para a língua. Meu neologismo tem a vida do momento em que dele preciso ${ }^{\prime 141}$. Do ponto de vista dos grandes escritores, podemos refletir sobre o sentimento de falta de palavras para sua expressão, a partir do depoimento do próprio

\footnotetext{
${ }^{137}$ GUILBERT, Louis. La Créativité Lexicale. Librarie Larousse, Paris,1975, p.48. (Na origem do novo termo encontramos uma motivação de falta que reside na não conformidade dos termos existentes no léxico com o conteúdo a ser expresso). (Tradução nossa).

${ }^{138}$ ALVES, Ieda Maria. Neologismo, Criação Lexical. São Paulo: Ática, 2007, p. 78.

${ }^{139}$ GUILBERT, Louis. Op. cit., p.31

${ }^{140}$ Ibid., p.40. (reside na necessidade de nomear um objeto, um novo conceito. Responde apenas à necessidade de comunicar uma nova experiência; não se inspira em considerações estéticas, mas com preocupações de eficácia). (Tradução nossa).
}

${ }^{141}$ DANIEL, Mary Louis. João Guimarães Rosa: Travessia Literária. Rio de Janeiro: Livraria José Olímpio, 1968 , p. 34 
Guimarães Rosa a Günter Lorenz, que também se referiu à precariedade do léxico disponível: "Quando escrevo, repito o que vivi antes. E para estas duas vidas um léxico apenas não me é suficiente". E na mesma conversa explica outro ponto de partida para o fenômeno que o consagrou como grande inovador do léxico: “[... ] a vida, a morte, tudo é, no fundo, paradoxo. Os paradoxos existem para que se possa exprimir algo para o qual não existem palavras."142

A criação neológica estilística, comum aos escritores, "est lieu à l'originalité profonde de l'individu parlant, à sa faculté de creation verbale, à sa liberté d'expression, en dehors des modèles reçus ou contre les modèles reçus" ${ }^{143}$. Repousa no reconhecimento da força expressiva da palavra responsável por traduzir antigas ou novas ideias de forma original, na percepção inédita da visão pessoal ou de um grupo sobre o mundo e na força incontida do desejo de realçar, de inovar, de revigorar a expressão literária e buscar, como queria Guimarães Rosa, o significado mais preciso das palavras.

Além disso, decorrem, as novas palavras, da busca, pelo discurso literário, da multissignificação, da polissemia e da pluri-isotopia em uso insólito.

Como o caráter social da gênese da criação lexical está diretamente ligado às necessidades individuais ou dos grupos humanos de projetarem linguisticamente, em determinado momento, sua percepção de uma nova proposição, devemos considerá-la em suas relações com o caráter essencial da linguagem, a função de comunicar uma nova informação, que deve primar pela clareza.

Alves, assim como Guilbert, consideram "que o léxico é representado por unidades lexicais relacionadas ao universo referencial, ao movimento do mundo $e$ da sociedade. " ${ }^{144}$ Também Barbosa reconhece, em seu desempenho, a função referencial (pendor que Jakobson admitiu como predominante dentre as funções de numerosas mensagens), portadora de informação de um novo conceito do universo antropocultural. ${ }^{145}$

O novo fato antropocultural e o novo signo não são por si só porém, do ponto de vista sociológico, o resultado mais importante de todo o processo da nova formação.

\footnotetext{
${ }^{142}$ Grandes entrevistas, Guimarães Rosa 2. Disponível em: < HTTP://www.tirodeletra.com.br/entrevistas/GuimarãesRosa-1965.htm> Acesso em: 09 de jun. 2011.

${ }^{143}$ GUILBERT, Louis. La Créativité Lexicale. Librarie Larousse, Paris, 1975, p.41.(é o lugar de profunda originalidade do falante, da sua faculdade de criação verbal, da sua liberdade de expressão em relação aos modelos recebidos ou contra os modelos recebidos). (Tradução nossa).

144 ALVES, Ieda Maria. A Unidade Lexical Neológica: Do Histórico-Social ao Morfológico. In: As Ciências do Léxico. Campo Grande: UFMS, 2004, p.78.

${ }^{145}$ BARBOSA, Maria Aparecida. Léxico, Produção e Criatividade. São Paulo: Editora Plêiade, 1996, p.82
} 
É o reflexo de toda uma conjuntura mais complexa e que merece análise mais minuciosa. Na realidade, o mecanismo de formação do novo signo, ou de atribuição de um novo significado aos signos já existentes, é um processo frequentemente complexo, de formulação e de seleção das proposições feitas no quadro do grupo social interessado. ${ }^{146}$

Concluímos que o estudo da gênese da unidade lexical trará como resultado conclusões sobre o perfil dos grupos socioculturais: seus valores, atividades, interesses, raízes históricas, míticas ou místicas, comportamentos socialmente prestigiados como observamos anteriormente. Ao ser utilizado, o novo signo evoca sua função social, elemento integrante do signo, reflexo de comportamentos, ou seja, uma situação dotada de significação social, que pode revelar a ideologia e as facetas culturais próprias de um grupo, tornando-se, sob esse aspecto, o que Barbosa denominou "signo-símbolo",147.

O signo-símbolo não apenas transmite um novo conceito, mas evoca uma cultura, ideologia ou filosofia dominantes e, por esse motivo, só pode ser definido em sua significação dentro do contexto que lhe deu origem, pois embora possa ser comum a vários grupos linguísticos, em diferente etapas de sua história, cada grupo apreende de modo exclusivo os dados da realidade.

Barbosa cita Greenberg, apud Rey, que utiliza a melhor metáfora para explicar a coexistência da língua de uma comunidade e o conteúdo das experiências sociais que se refletem no léxico quase que em simultaneidade: "Le lexique d'une langue est comme un miroir du reste de la culture" ${ }^{\text {148 }}$, pois qualquer alteração que se dê no inventário léxico é reflexo de uma alteração cultural no seio de uma comunidade e o inverso também é verdadeiro. Ao condensar as experiências culturais, no sentido antropológico - a civilização enfim, de um povo - em sua totalidade, um novo fato gerado modifica simultaneamente o léxico, e a criação lexical modifica por sua vez a estrutura do léxico da língua. ${ }^{149}$

Todo novo fato, ao mesmo tempo em que é apreendido é também elaborado, imperceptivelmente, de acordo com as normas de elaboração de conteúdo e expressão preexistentes em uma dada língua. O papel da língua é o de modelar e gerar ideias, pois,

\footnotetext{
${ }^{146}$ BARbOSA, Maria Aparecida. Léxico, Produção e Criatividade. São Paulo: Editora Plêiade, 1996, p.118, 119.

${ }^{147}$ Ibid., p. 120.

${ }^{148}$ Ibid., p.121. (O léxico de uma língua é como o espelho de uma cultura). (Tradução nossa).

149 Ibid., p.120.
} 
"enquanto a língua se constrói, constrói-se a cultura de um povo" ${ }^{150}$. Ou, conforme afirma Alves, ao considerar as relações entre língua e neologia enquanto fato social, e a estrutura social e os avanços da sociedade e sua mudança correspondente na estrutura linguística: “ $o$ estudo sistemático da neologia no português brasileiro é, sob a perspectiva linguística, a análise dos processos de formação de novas palavras; do ponto de vista extralinguístico, constitui o estudo da evolução da sociedade brasileira." 151

Alves cita ainda Isquerdo para nos auxiliar a entender a importância da representação histórica e social da unidade lexical neológica:

É justamente no nível lexical que as formas se articulam de maneira a possibilitar a representação e a configuração das experiências do grupo, visto ser o léxico o elemento que revela a história social e cultural do grupo, sua experiência de vida e o modo como organiza simbolicamente o mundo. ${ }^{152}$

Em resumo, a relação entre a expansão do acervo léxico e a inovação social está ligada à percepção de um novo dado no universo antropocultural e à incapacidade das unidades preexistentes de expressarem a nova informação, por não conterem todos os semas necessários para sua representação. A atualização, no ato de fala, da novidade léxica, como elemento efetivo, antes apenas virtualidade do sistema, tem esse "duplo caráter de exclusividade de enunciação e virtualidade ${ }^{\text {} 153}$ que se torna elemento disponível para uso de um ou mais falantes, e ao mesmo tempo, também, explicação do seu universo referencial.

Feitas estas considerações, sobrevém a peculiar posição ocupada pela Etnoterminologia dentre as ciências do léxico. As relações que se estabelecem na criação lexical, entre os universos de discurso da linguagem comum, da linguagem técnico-científica, da linguagem literária ou não e da linguagem etnoliterária, em suas semelhanças e diferenças são, de fato, importantes. Cada universo de discurso porta marcas, como dissemos anteriormente, que o classifica dentro de um domínio da experiência humana, o que determina seu universo de discurso específico. Ou seja, cada universo de discurso guarda em si um

\footnotetext{
${ }^{150}$ BARBOSA, Maria Aparecida. Léxico, Produção e Criatividade. São Paulo: Editora Plêiade, 1996, p.122.

${ }^{151}$ ALVES, Ieda Maria. A Unidade Lexical Neológica: Do Histórico-Social ao Morfológico. In: As Ciências do Léxico. Campo Grande: UFMS, 2004, p.79.

152 BARBOSA, Op. cit., p. 122.

${ }^{153}$ Ibid., p.139.
} 
recorte inusitado da substância semântica lexical, que nasce no ambiente sócio-linguísticocultural, que só é traduzido, em sua essência, nesse ambiente, reflexo do processo de formulação e de seleção das proposições de determinado grupo social.

Cabe-nos observar que nos limites da expressão literária em que se insere a etnoliteratura, pode ela ser enriquecida com os elementos que vão além da busca de originalidade ou que nasçam da falta da melhor palavra. O vocábulo-termo agrega novas ideias denominadas a partir da realidade de um mundo original ou desconhecido, facultado pelo etnismo que reveste o vocábulo-termo de funções míticas e pedagógicas, pela adição de novos semas somente aplicáveis a determinados lexemas no universo de discurso etnoliterário.

No âmbito da Etnoterminologia, o enriquecimento lexical não é determinado pela vontade, mas pela necessidade imediata de denominação e pela tendência de grupos isolados como o de Januária, em Minas Gerais, de inventar palavras. Esta forma de criação linguística é intuitiva, com regras próprias que se reiteram e acentuam sua característica de instrumento naturalmente herdado, que consolida a eficácia da comunicação.

A Etnoterminologia, nos tênues limites entre a Lexicologia e a Terminologia, ocupa-se do signo linguístico que se refere a um conceito específico dominado por um grupo de falantes que o identifica e denomina no processo de sua explicação no universo referencial. As relações étnicas são documentadas pela língua e a identidade dessas relações é "formada" 154 em grandezas-signo modelizantes da realidade fenomênica, que podem transformar-se em signos-símbolo. A exclusividade denominativa reveste-se de caráter monorreferencial, que na análise da formação dos semas conceptuais e na caracterização semântico-conceptual do vocábulo-termo poderemos retomar com maior clareza.

\footnotetext{
${ }^{154}$ De 'formar', termo utilizado por Maria Aparecida Barbosa: trata-se do processo de recortar culturalmente um fato antropocultural.
} 


\subsubsection{As denominações e suas especificidades}

Denominar qualquer palavra diferente ou qualquer palavra em uma acepção inusitada como termo é prática comum mesmo entre os estudiosos da língua e, principalmente, entre os falantes da língua geral. Mais do que prática, diremos que se trata de reflexão sobre a linguagem, de esforço para classificar a denominação, processo essencial na elaboração dos fatos. Ou seja, podemos dizer que a denominação termo para a palavra diferente é intencional, para, num ato de fala, atribuir significação a características específicas observáveis ou de algum modo intuídas, e distingui-la das palavras que não pertencem ao universo lexical de uso do falante da língua geral. Sua utilização se faz considerando-se as características especiais de conjuntos de palavras em concorrência com a língua comum, com função outra nos universos de discurso dos diferentes grupos e mesmo com outra significação. Em outras palavras, há o empréstimo da palavra da língua de uso geral, com especificidade de significação e função no falar de cada grupo social.

Sabemos que Rosa povoa uma região desabitada com uma multidão dos nomes que podem aparecer apenas uma vez na sua obra. Mas seu interesse pelo nome não se prende apenas ao homem, mas a toda espécie de fenômenos e fatos, conforme chegou a explicar: " $a$ vida é uma reverente e espantada nomeação de fenômenos". Esse seu interesse é demonstrado ao dizer também: "Eu não escrevo difícil. Eu sei o nome das coisas" "155

O conhecimento do homem sobre a realidade e a necessidade de dominá-la resultou na estruturação do mundo pelo processo de nomeação, ao classificar em rótulos os seres e os objetos, em suas semelhanças e diferenças, gerando assim o léxico das línguas naturais, reorganizado incessantemente a cada novo ato de cognição e análise da realidade. ${ }^{156}$

A denominação é um processo que faz parte de um ritual primeiramente descrito na Bíblia, e a linguagem adâmica acompanha o homem na tarefa de atribuir nomes próprios aos seres que pretende únicos, um nome que lhes pertença de modo consubstanciado, inalienável.

De fato, a preocupação do homem com as denominações e suas classificações remonta à Antiguidade grega de Aristóteles, e a todos os campos clássicos do saber. Alan Rey nos lembra que a obra Cratylus, de Platão, pode ser considerada o primeiro texto básico sobre

\footnotetext{
${ }^{155}$ COSTA, Ana Luiza Martins. Veredas de Viator. In: Cadernos de Literatura Brasileira, João Guimarães Rosa. São Paulo: Instituto Moreira Salles, 2006, p.213.

${ }^{156}$ BIDERMAM, Maria Teresa de Camargo. As ciências do léxico, In: As Ciências do Léxico. Mato Grosso do Sul,CPIE-UFMS-INEP, 2011, p.13.
} 
terminologia, o campo de estudos "fundamentally concerned with names and the process of naming". 157

Nos tempos de hoje, além do aprofundamento das ciências antigas, a avalanche das descobertas de novos fenômenos, nos novos campos de conhecimentos técnicos e científicos e, em consequência da revisão de antigos conceitos à luz dos novos conhecimentos, só faz deles derivar uma imensa quantidade de denominações que podem confundir os falantes mais experientes e bem informados. Muitas vezes, dá-se um choque entre as diferentes faixas etárias, incapazes que são os adultos de se localizarem no universo de discurso dos adolescentes, por apresentar esse discurso as marcas da evolução dos costumes.

Marieta Prata de Lima Dias nos explica de que modo os fenômenos são passíveis de denominação:

O objeto individual, limitado no tempo e também entendido como indivíduo ou exemplar, é abstraído pelo conceito e tem caráter material (ex. : mesa e mão) ou imaterial (ex.: terremoto e medo); é denominado por nome próprio ou, mais comumente, por palavras que não são nomes próprios - as denominações - que, muitas vezes são discursivamente fixadas no espaço e no tempo por expressão dêitica. ${ }^{158}$

O signo linguístico de Saussure, sabemos, caracteriza-se pela associação de uma imagem acústica e um conceito indissociáveis, reportando-se, como um todo, a um objeto no mundo exterior a que chamamos de referente. O referente é parte da realidade, ao passo que o significante é a representação da realidade, uma abstração dela, a primeira classificação dos elementos do mundo. ${ }^{159} \mathrm{O}$ significado, por sua vez, contém a estrutura semântica do vocábulo, e este sim é rico e complexo.

De acordo com Barbosa, a denominação é um tipo de processo que se desenvolve no percurso gerativo da enunciação de codificação, que pode ser descrito do seguinte modo: referente (real ou imaginário), conceptualização (representação), escolha de um signo

\footnotetext{
${ }^{157}$ REY, Alain. Origins and Development of Terminology. Essays on Terminology. Amsterdam/Philadelphia. John Benjamins, 1995, v. 9, p.11. (A Terminologia está fundamentalmente interessada pelos nomes e com o processo de nomear). (Tradução nossa).

${ }^{158}$ DIAS, Marieta Prata de Lima. A etapa terminográfica de elaboração de sistemas temáticos.In: Acta Semiotica et Lingvistica. v.9, 2002, São Paulo: Terceira Margem, 2002. p.126.
}

${ }^{159}$ SALMINEM, A.N. Analyse sémantique du lexique. Armand Colin, p.92. 
(adequação relativa) $^{160}$. Portanto, compreendemos que o significante capaz de abarcar o conceito enquanto representação do referente tem sua gênese no ato de conceptualização, e é simbolizado por um nome de batismo. O conceito é pré-linguístico e pré-semiótico, e prescinde de denominação simultânea, pois a percepção e a conceptualização é anterior à denominação do fato estabelecido no universo antropocultural.

William Shakespeare, na peça Romeu e Julieta, cunhou, nos lábios de Romeu, a frase paradigmática que inúmeras vezes utilizamos para explicar o famoso princípio saussuriano da arbitrariedade do signo linguístico "But what's in a name? That which we call a rose by any other name would smell as sweet" ${ }^{, 161}$.

Não existe uma relação necessária que una o significado ao significante e, portanto, qualquer sequência significante pode representá-lo, pois a cadeia sonora não tem relação com a realidade, é imotivada. A não ser, evidentemente, nos casos das onomatopeias. Por outro lado, os conteúdos que enriquecem um nome estabelecem uma relação de significação com a expressão, e a expressão com tais conteúdos, passíveis de serem instauradas pelo falante a partir do interesse que o fenômeno lhe despertar.

Para Dick, a denominação gerada por um grupo "manifesta seu entendimento quanto à percepção do real e à qualidade do dado recebido, garantindo, ao mesmo tempo, a simultaneidade da geração dos processos gramaticais e da elaboração dos sociofatos". ${ }^{162}$

Uma vez estabelecido o vínculo de alguma ordem entre o significante e o seu referencial na realidade, este pode de tal forma a ele enraizar-se a ponto de o significado, que o significante representa, afastar-se e ocultar o conteúdo semântico original. Observamos, dessa forma, o esvaziamento semântico da denominação.

Mas podem os nomes associar-se aos seus referentes de modo a tornarem-se uma única realidade, assumindo vida. Desse modo, o caráter do nome deixa de ser arbitrário, passando a ser motivado com diferentes funções: função icônica e arquetípica, função de variável cultural, função motivadora, memorialística e identitária, sendo sua permanência fator de estabilidade social.

\footnotetext{
${ }_{160}$ BARBOSA, Maria Aparecida . Aspectos conceituais, terminológicos e políticos das denominações: discurso científico e discurso político.. In: 57ª. Reunião Anual da SBPC, 2005, Fortaleza - CE. Anais/Resumos da 57º Reunião Anual da SBPC. São Paulo - SP : SBPC/UECE, 2005. v. 1. p. 1, 2

${ }^{i 61}$ SHAKESPEARE, William. Romeo e Julieta.(Mas o que é um nome? Aquilo a que chamamos rosa, com qualquer outro nome teria o mesmo perfume). (Tradução nossa)

${ }^{162}$ DICK, Maria Vicentina de Paula do Amaral. O nome próprio: significação e referência. (Artigo do curso Elementos de Terminologia e Etnolinguística, USP, 2009)
} 
Observou Saussure, no capítulo que intitulou "O Testemunho da Língua em Antropologia e em Pré-História”, no antológico "Curso de Linguística Geral”, que a unidade, a mais essencial em uma comunidade linguística, é aquela constituída pelo vínculo social ao qual chamou etnismo. O etnismo "repousa nas relações de religião, civilização, defesa comum etc.", e a raça não é, senão, fator secundário de unidade de língua. Ensinou o famoso linguista que a língua é um documento histórico, capaz de testemunhar. Estabelecem-se entre grupo social e língua relações que naturalmente podem existir entre "língua e raça ou civilização":

[...] o vínculo social tende a criar a comunidade de língua e imprime talvez ao idioma comum determinados caracteres; inversamente, é a comunidade de língua que constitui, em certa medida, a unidade étnica. Em geral, esta sempre basta para explicar a comunidade linguística. ${ }^{163}$

Saussure citou-nos como exemplo que, na convivência entre latinos e etruscos, na Itália antiga, apenas a língua pode testemunhar o que têm ou não em comum os dois povos: "quatro linhas de etrusco bastam para mostrar-nos que o povo que o falava era absolutamente distinto do grupo étnico que falava latim." 164

Podemos concluir, desse modo, que a língua que falamos nos é transmitida como herança, capaz de explicar experiências vividas pelo nosso grupo social.

Condiz com essa afirmação de Saussure a relação de palavras colhidas por SaintHilaire em sua viagem às nascentes do rio São Francisco, tais como: Vertentes do Jacaré, São Miguel e Almas, Registro dos Arrependidos, Porto do Quebra Anzol, Braço do Veríssimo; e também as colhidas na expedição de Martius: Bonfim, Bemposta, Sem-Dentes, Foge-Homem, Arrependido; assim como as que o próprio Cavalcanti Proença enumera após citar os viajantes, em sua análise depois de lançado o romance de 1956: Sertão da Farinha Podre, Quebra-Cangalha, Bate-Bruaque, Capão do Cleto, Desemboque. Muito bem observou Proença que poderiam estas palavras fazer parte da geografia de Grande Sertão: Veredas ${ }^{165}$.

\footnotetext{
${ }^{163}$ SAUSSURE, Ferdinand de. Curso de Linguística Geral. São Paulo, Editora Cultrix, 1971, p. 261.

${ }^{164}$ Ibid., p. 261, 262

${ }^{165}$ PROENÇA, Manuel Cavalcanti. Trilhas no Grande Sertão. Os cadernos de Cultura. Ministério de Educação e Cultura, 1959, p.93, 94.
} 
Como dissemos anteriormente, as relações étnicas são documentadas pela língua e a identidade dessas relações é formada em grandezas sígnicas modalizantes da realidade fenomênica que assegura à exclusividade denominativa seu caráter monorreferencial.

Desse modo, ao denominar, o grupo se faz presente, com suas características sociais, suas atividades, valores e objetivos que comunga. São estes os traços, que uma vez mais atestam a função social constitutiva do signo que, no nosso entender, vai além dos parâmetros das funções e significações do vocábulo da língua geral, penetrando nas funções e significações do termo das linguagens de especialidades também, isomorficamente assentados nos limites da Etnoterminologia com a Terminologia. Estudos de Júlia Conceição Fonseca Santos, citados por Leonardo Arroyo, acerca dos nomes de vários personagens de Rosa, levam-na a concluir sobre "uma provável tendência na região a realizar alterações" nos nomes, com reduções hipocorísticas e substituições de im por inho ou ino, de acordo, por exemplo, com as condições sociais dos falantes. Arroyo cita que Riobaldo foi chamado de Tatarana e Urutu Branco "conforme" a sua "pessoa" em diferentes condições.

As denominações em Grande Sertão: Veredas cumprem, ainda, a função de assinalar aspectos da cultura sertaneja do homem do sertão como, por exemplo, seu gosto pelos nomes longos, originais e exóticos tão tipicamente brasileiros, seguindo por vezes tendências coloquiais como a criação de epítetos e alcunhas, como em Exaltino-de-trás-da-Igreja, Hermógenes, Otacilia, Maria Deodorina.

O recurso ao hífen é de grande relevância no aproveitamento dos topônimos longos e realistas como em Serra do Pau-d’Arco, Cruzeiro-das-Embaúbas, Detrás-das-Duas-Serras, como observou Mary Lou Daniel ${ }^{166}$.

Em Grande Sertão: Veredas, a paisagem natural denominada é minuciosamente classificada na exuberância do conjunto dos animais que a povoam, dos pássaros, plantas e árvores que proliferam na geografia dos Campos Gerais. E também na abundância de cidades, lugarejos, rios, chapadas, chapadões e veredas arrolados, quer sejam reais ou gerados pela inventiva de Rosa.

Como que para delimitar uma geografia desconhecida, Rosa registra-a com a minúcia de um geógrafo, denominando vilarejos típicos e acidentes geográficos de toda ordem. Assim como um naturalista não menos meticuloso, relaciona infindas listas da fauna e da flora como que a lhes autenticar a origem, e fazem-se presentes, estão em abundância, travestidos de

\footnotetext{
${ }^{166}$ DANIEL, Mary Lou. João Guimarães Rosa: Travessia Literária. Rio de Janeiro: Livraria José Olímpio, 1968, p.72
} 
deliciosas sutilezas linguísticas e significações inusitadas e complexas, irremediavelmente associadas aos seus referente e significante.

Nesse espaço o nome é concebido, e nome e espaço, nomes e seres são consubstanciados em entidades reais da geografia em que se sucedem os acontecimentos e se tornam seus símbolos. As denominações, formuladas em grandezas-signos, pertencem aos seres de toda ordem, como marca de identidade ao mesmo tempo em que os expressam poeticamente.

O que dizermos então dos nomes próprios dos seres humanos que habitam a solidão do sertão? Eles abrem um capítulo de especial importância e tiram do anonimato o mais Miguilim dos seus personagens, pois com percepção criativa ou com conhecimento de causa, ao denominar Miguilim sua personagem infantil, de Campo Geral, tornou-a símbolo do menino míope que gostava de contar estórias.

Leonardo Arroyo ${ }^{167}$ pergunta se Rosa não teria acrescido ao nome, o sufixo “im”, tão mineiro, em sentido antônimo ao de "miguelar os olhos", expressão usada em Januária, que "significa arregalar os olhos".

Seja como for, em Cordisburgo pudemos registrar, em nossa visita, o neologismo Miguilim(s), que designa os meninos que contam as estórias de Rosa. São adolescentes entre dez e dezoito anos, pertencentes ao Grupo Miguilim, que recepcionam os visitantes declamando a obra de Guimarães Rosa. Calina Guimarães, prima do escritor, criou o grupo em 1995, que hoje é dirigido por Dora Guimarães, sua também prima, e Eliza Almeida. Em conversa com Dora, ela mesma observou que não havia vinculado o conceito ao nome. A verdade é que verificamos o neologismo $\operatorname{Miguilim}(s)$ incorporando-se ao léxico dos habitantes da cidade e dos turistas que visitam o museu, que outrora fora a casa em que o escritor morou com sua família.

Elaboramos também uma pesquisa com informantes de Cordisburgo. A partir do levantamento de vocábulos constantes da obra, solicitamos a estudiosos, viajantes e moradores da região do sertão a identificação das palavras de baixa frequência, da lista fornecida pelo programa Wordsmith Tools. Entretanto, muitas vezes, uma palavra de baixa frequência nos remetia a outra, que nos parecia importante, bonita, característica do etnismo do ambiente sertanejo.

\footnotetext{
${ }^{167}$ ARROYO, Leonardo. A Cultura popular em Grande Sertão Veredas. Rio de Janeiro, Livraria José Olímpio Editora, 1984, p.9.
} 
Os informantes ${ }^{168}$ foram solicitados a assinalar a palavra reconhecida do vocabulário sertanejo em uso. Pudemos identificar algumas palavras ou expressões do léxico de Grande Sertão ainda em uso pelo sertanejo, como por exemplo: a crevo, aos dava, alonjada, bilhas nas rodilhas, catapruz, catrumano, carnear, coité, correão, do oco para o ocão, drongo, grameal, jacuba, lazo, matula, no vertinoginosamente, peta, por boca de ruindade, quicé, quizília, resfriado, retentiva, sarro, sebaça, sufusa, tomar faro, tribuzana, tropilha, vau, verdolenga, zureta, e algumas referências a cavalos: murzelo-mancho, murzelo-andrino, gateado, preto galopeiro, cavalão-rão.

Em nossos contatos, perguntamos ao senhor José Oswaldo dos Santos, conhecido como Brasinha, admirador e conhecedor profundo da obra de Rosa, sertanejo, morador de Cordisburgo (de Minas, atilado, como diria Rosa), sobre as cores dos cavalos, que tanto atraiam a atenção do autor. Mais uma vez observamos que a visão específica do fato se reflete na língua de modo muito particular:

\begin{abstract}
Na nossa região as cores dos cavalos se definem da seguinte maneira: Cavalo preto ou branco são animais de uma só cor, bem firme. Quando falam por exemplo: preto foveiro, preto cinzento, preto morcego, preto cadão, branco amarelado, branco russo, branco encardido estão designando cores que não são exatas.
\end{abstract}

Greimas já tomou a Hjelmslev o clássico exemplo do espectro das cores, que neste momento retomamos: o eixo semântico que, no caso, se refere às cores dos cavalos, é encontrado em todos os grupos linguísticos e possui grande generalidade, uma vez que as cores estão presentes em todas as civilizações ${ }^{169}$. A articulação sêmica produzida atualmente pelo sertanejo dos gerais é uma categorização estruturada por uma cultura diferente da cultura urbana, não acostumada com cavalos e suas nuances de cores. Poderíamos assim representar, a exemplo de Hjelmslev, as articulações das cores preta e branca, na seguinte tabela:

\footnotetext{
${ }^{168}$ Dora Guimarães; Seu Chico, caseiro de Dora, nascido no norte de Minas; José Oswaldo dos Santos (Brasinha); Rosa Haruco Tane (Rodas de leitura do IEB).
}

${ }^{169}$ GREIMAS, A.J. Semântica Estrutural. São Paulo: Cultrix, 1973, p.36, 37. 


\begin{tabular}{l|l}
\multirow{4}{*}{ cavalo preto } & cavalo preto foveiro \\
\cline { 2 - 2 } cavalo branco & cavalo preto cinzento \\
\cline { 2 - 2 } & cavalo preto morcego \\
\hline \multirow{4}{*}{ cavalo preto cadão } \\
\cline { 2 - 2 } & cavalo branco amarelado \\
\cline { 2 - 2 } & cavalo branco russo \\
\hline
\end{tabular}

Enfim, mesmo o leitor menos atento percebe que Rosa reverenciava a palavra que nos enreda nos labirintos linguísticos que nos incitam a refletir sobre o uso que o autor e sertanejo fazem do léxico, que vem acompanhada pela fascinação do autor pelo nome, resultando em extenso e rico acervo das denominações, do vocabulário do sertanejo das veredas do sertão dos Gerais.

Riobaldo assim se expressa em defesa do nome: "Todos os nomes eles vão alterando. É em senhas. São Romão todo não se chamou de primeiro Vila Risonha? O Cedro e o Bagre não perderam o ser? O senhor concorda? O Tabuleiro-Grande? O senhor concorda? Nome de lugar onde alguém já nasceu, devia de estar sagrado." ${ }^{170}$ A reflexão de Riobaldo e a teoria que embasa a concepção dos signos linguísticos nos levam a ponderar que a semiotização, própria de um grupo etnolinguístico não poderia admitir, a priori, a interferência posterior nas denominações, fruto do "batismo" atribuído quando da seleção dos traços caracterizadores do fato natural.

Escreveu Pedro Xisto seu contemporâneo: “Os vocábulos do nosso romancista-poeta não se restringem a contar uma estória. Eles têm ainda, o que contar de si próprios. Eles são mais do que signos abstratos e indiferentes. Eles integram a coisa, participando, concretamente, das vivências."171

\footnotetext{
${ }^{170}$ ROSA, João Guimarães. Grande Sertão: Veredas. Rio de Janeiro: Nova Fronteira, 2006, p.42

${ }^{171}$ XISTO, Pedro. Guimarães Rosa em Três Tempos. CEC, Comissão de Literatura, p.14
} 
E acrescenta, em nota de rodapé, que o próprio Guimarães Rosa lhe teria dito que "certos nomes próprios decidiam os respectivos personagens e que certas estórias foram, grandemente, alteradas sob essa onomástica ação-presença."172

${ }^{172}$ XISTO, Pedro. Guimarães Rosa em Três Tempos. CEC, Comissão de Literatura, p.14 


\section{ESTABELECIMENTO DO CORPUS}

Estabelecemos como corpus de análise, as palavras de uso da língua geral, porém com significado diferente, pertencentes à vertente etnoliterária de Grande Sertão: Veredas, escolhidas dentre as palavras-chave da obra.

\subsection{Perfil do texto constitutivo do corpus}

Grande Sertão: Veredas integra o limitado grupo dos cem livros mais importantes de todos os tempos, de acordo com o prestigiado Círculo do Livro da Noruega ${ }^{173}$. No Brasil, a edição de 2006 de Grande Sertão nos informa na contracapa que "a Folha de São Paulo, a Revista Época e várias associações internacionais elegeram Grande Sertão como um dos cem maiores livros da literatura universal do século XX"174.

Escrito inicialmente para figurar como uma das nove novelas do livrão, livralhão, conforme Rosa se referiu a Corpo de Baile, Grande Sertão:Veredas tomou vulto inesperado, como confidenciou Rosa, e adquiriu vida própria, constituindo-se, dessa forma, no único romance escrito por ele, fruto da sua planejada viagem, com duração de um mês e extensão de duzentos e quarenta quilômetros, ao sertão de Minas Gerais, em maio de 1952.

Seu título, declarado à revista Visão, em julho de 1954, seria o de As Veredas Mortas, que naturalmente sofreu alterações até chegar à sua forma final. No primeiro rascunho, o primeiro título $O$ diabo na rua, no meio do redemoinho, aparentemente foi substituído por Veredas Mortas, constando o título Grande Sertão:Veredas, seguido do subtítulo, $O$ diabo na rua, no meio do redemoinho, no segundo rascunho, ambos pertencentes à esposa do escritor. $^{175}$

As anotações dessa e de outras viagens estão em seus famosos caderninhos aos quais amarrava um lápis apontado em ambas as extremidades, preso ao pescoço, e registrava todas

\footnotetext{
${ }^{173}$ HTTP:// WWW.educarparacrescer.abril.com.br/leitura/grandesertão - veredas.shtml. Acesso em 06 ago. 2011.

${ }^{174}$ ROSA, João Guimarães. Grande Sertão: Veredas. Rio de Janeiro: Nova Fronteira, 2006

175 COSTA, Ana Luisa Martins. Via e viagens: a elaboração de Corpo de baile e Grande sertão:veredas, In: Cadernos de Literatura Brasileira: João Guimarães Rosa, Instituto Moreira Salles, 2006, p. 200, 201.
} 
as questões procedentes da sua curiosidade profunda e sem limites. Além deles, encontramos uma extensa coletânea dos documentos do autor, organizados no Instituto de Estudos Brasileiros, negociados por Eduardo Carvalho Tess, enteado de Rosa, junto ao então reitor da Universidade de São Paulo, Miguel Reale, que resultou neste importante e rico acervo.

Ambos os livros, Grande Sertão: Veredas e Corpo de Baile foram escritos entre 1953 e 1955, e surpreendentemente foram lançadas suas duas mais extensas obras, no mesmo ano de 1956.

No caso de Grande Sertão imaginou o autor dividi-lo em duas partes, uma das quais, a segunda, teria por título Grande Sertão: Cidades $^{176}$. No ano de sua publicação, o romance ganhou o prêmio "Machado de Assis", do Instituto Nacional do Livro e, desde então, projetou-se na literatura brasileira e internacionalmente, ao ser traduzido em várias línguas.

Mais do que uma dedicatória, o livro foi presenteado à sua mulher, Aracy Moebius de Carvalho, em homenagem ao seu desvelo, enquanto o escrevia. Sobre essa dedicação, assim comentou com Lorenz:

[...] enquanto escrevia Grande Sertão, minha mulher sofreu muito porque nessa época eu estava casado com o livro. Por isso dediquei-o a ela, para agradecer-lhe por sua compreensão e paciência. Você deve saber que tenho uma mulher maravilhosa. Como sou um fanático da sinceridade linguística, isto significou para mim que lhe dei o livro de presente, e portanto, todo dinheiro ganho com esse romance pertence a ela, somente a ela e pode fazer o que quiser com ele. ${ }^{177}$

O célebre diálogo, iniciado por um travessão, na verdade camufla um monólogo, só concluído cerca de seiscentas páginas depois, com o símbolo do infinito. Sem espaço para qualquer capítulo, sustenta-se com alusões de Riobaldo ao seu interlocutor, de quem sugere, ao longo da narrativa, quer em forma de respostas, que teriam sido dadas às suas perguntas, ou em forma de descrições, suas características. A vida ilógica, passada a limpo pelo narrador, tem a veracidade das efabulações folclóricas ao servir-se da oralidade, e também dos volteios próprios da literatura de cordel, dos contos e lendas contados pelos velhos, conforme

\footnotetext{
${ }^{176}$ DANIEL, M. L. João Guimarães Rosa, Travessia Literária. Rio de Janeiro, Editora José Olímpio, 1968, p.9

${ }^{177}$ Grandes entrevistas, Guimarães Rosa 2. Disponível em: < HTTP://www.tirodeletra.com.br/entrevistas/GuimarãesRosa-1965.htm> Acesso em: 09 jun. 2011
} 
justificou Rosa ao seu tradutor alemão: "eles não souberam deixar escritas suas estórias"178, cujas "aventuras não têm tempo, não têm princípio nem fim"179.

4.2 A Linguística de Corpus como instrumento de seleção de palavras-chave

Sabemos, muito embora sejam ainda escassos os trabalhos que utilizam a Linguística de Corpus para tratamento eletrônico de textos especificamente literários, que se trata de uma prática de pesquisa e observação do texto que se dissemina. É um suporte metodológico que pode colaborar na exploração estatística desse gênero textual, favorecendo análises que muitas vezes escapam a olho nu, e podem, através de métodos computacionais, serem reveladas (Louw) ${ }^{180}$, sobretudo se tivermos em conta que a língua é um sistema probabilístico.

Abordamos o léxico de Grande Sertão: Veredas em formato eletrônico por meio da Linguística de Corpus, amparados na premissa de Bowker e Pearson, citados por Sergio Marra Aguiar ${ }^{181}$ de que "o volume dos textos que compõe o corpus deve ser extenso o bastante para justificar a utilização de recursos computacionais para exploração dos seus conteúdos." Como poderemos observar, esse tipo de exame nos permitiu uma análise mais acurada do léxico de Grande Sertão: Veredas.

Escolhemos o programa WordSmith Tools, de Mike Scott, em sua versão 5.0, de 2009, que nos apresentou dados a respeito do corpus de pesquisa como: o número total de palavras do texto (tokens), o número de palavras distintas do texto (types), e a proporção entre tokens e types (types/token - TTR), dentre outros.

O programa disponibiliza as ferramentas Wordlist, Keywords e Concord, a partir das quais geramos uma wordlist, ou seja, a lista com a frequência de cada palavra do corpus, as palavras distintas (types), e observamos na amplitude do corpus de Grande Sertão, com cerca

\footnotetext{
${ }^{178}$ Grandes entrevistas, Guimarães Rosa 2. Disponível em: < HTTP://www.tirodeletra.com.br/entrevistas/GuimarãesRosa-1965.htm> Acesso em: 09 jun. 2011

${ }^{179}$ Ibid.

${ }^{180}$ WYNNE, M. Stylistics: corpus approaches. Oxford University, 2005 p.4

${ }^{181}$ AGUIAR, Sergio Marra. As vozes de Chico Buarque em inglês: Tradução e Linguística de Corpus.Tese (Doutorado). FFLCH/USP.São Paulo, 2010, p.94.
} 
de 191.000 palavras ${ }^{182}$, a distribuição quantitativa das formas linguísticas vinculadas ao seu contexto, para analisar qualitativamente a chavicidade (keyness) dessas palavras: os empregos, as ocorrências e as co-ocorrências dos itens lexicais e sua classificação em aspectos semânticos ligados à cultura popular herdada, traduzidos em conotações de etnicidade.

A primeira lista gerada pelo programa produziu uma relação da ocorrência, wordlist, com o número total de palavras (tokens) do corpus e a lista de palavras visualizadas em ordem decrescente, pois o número de vezes que cada item foi repetido (types) em relação à frequência é outro dado que aparece ao lado da palavra. A relação das palavras características em sua frequência nos dá a chavicidade da palavra (a sétima lista vertical gerada), ou seja, o quanto determinada palavra é chave em relação às palavras do corpus de referência estabelecido, indicada em números.

Em outras palavras, nos explica Aguiar, a partir de Berber Sardinha: "As palavraschave são classificadas com seu nível de chavicidade, ou seja, o grau de destaque das palavras no sentido de serem anormalmente frequentes no corpus de estudo em relação ao corpus de referência" "183 As palavras-chave são resultantes do cruzamento entre o corpus de referência e o corpus de análise e fornecem um padrão de comparação para o corpus de análise.

O corpus de Grande Sertão: Veredas foi submetido à comparação com outros corpora, denominados em seu conjunto de corpus de referência, no qual as palavras geradas produziram um valor de chavicidade em relação ao corpus de Grande Sertão: Veredas.

Análises experimentadas anteriormente nos dão conta de que bons resultados no item chavicidade são observados em corpora de referência pelo menos três vezes mais extenso do que o corpus de análise. Fizemos vários testes, observando os resultados com algumas mudanças de corpora de referência, concluindo que os resultados não faziam variar muito nossa lista de palavras-chave.

\footnotetext{
${ }^{182}$ A diferença existente entre o número de páginas entre a edição digitalizada (280), e a não digitalizada (608), deve-se ao seguinte fato: a versão da Nova Fronteira possui 201.575 palavras e a que usamos, 191.095. Essa diferença originou-se pela repetição do nome do autor ou do nome da obra que aparecem no começo de cada página. Em uma estimativa superficial, esses caracteres são computados, mais ou menos, como 12.300 palavras a mais, que é, aproximadamente, a diferença entre as edições. Além do mais podemos ver que a diagramação entre elas é diferente: enquanto a edição da Nova Fronteira possui letras grandes e maior espaçamento entre as linhas, a edição digitalizada possui letras pequenas e menor espaçamento entre as linhas).
}

${ }^{183}$ AGUIAR, Sergio Marra. As vozes de Chico Buarque em inglês: Tradução e Linguística de Corpus.Tese (Doutorado). FFLCH/USP.São Paulo, 2010, p.103. 
Definimos como corpora de referência, por sugestão da Prof ${ }^{a}$. Dr ${ }^{a}$. Stella O. Tagnin, do departamento de Língua Inglesa da USP, os três primeiros romances de Chico Buarque de Hollanda, compilados por Sergio Marra de Aguiar, orientando de Tagnin, na tese por ele defendida, As vozes de Chico Buarque em inglês: Tradução e Linguística de Corpus, contendo cerca de 112.000 palavras. São os seguintes os livros por Chico Buarque publicados: Estorvo, de 2004, Benjamim, de 1995 e Budapeste, de 2005, e o corpus de referência Lácio-Web. num total de cerca de 7.000.000 de palavras.

Lácio-Web (LW) é um projeto organizado em parceria entre NILC (Núcleo Interinstitucional de Linguística Computacional), localizado no ICMC-USP, IME (Instituto de Matemática e Estatística) e FFLCH (Faculdade de Filosofia, Letras e Ciências Humanas). Este projeto disponibiliza, na Web, vários corpora do português brasileiro escrito contemporâneo, representando bancos de textos compilados, catalogados e codificados em um padrão que possibilita ao usuário fácil intercâmbio, navegação e análise e, também, ferramentas linguístico-computacionais, tais como contadores de frequência, concordanciadores e etiquetadores morfossintáticos. Seu público-alvo são os linguistas, cientistas da computação, lexicógrafos, mas também não especialistas em geral.

É importante dimensionar a frequência com que determinadas unidades lexicais ocorrem no discurso rosiano, para determinarmos a motivação das formas lexicais: se resultante do repertório fundamental dos usuários de um universo de discurso, bem como a forma particular de um grupo de perceber a realidade e concebê-la, ou se produto da originalidade expressiva de um indivíduo.

Ao inventariar O Léxico de Guimarães Rosa, Nilce Sant`Anna Martins arrolou por volta de 8.000 palavras, o equivalente a $8,4 \%$ das 100.000 palavras que compõem a primeira edição do Novo Dicionário Aurélio. Dessas 8.000 palavras, Martins nos afirma que pelo menos 5.000 foram usadas apenas uma vez em toda a obra de Guimarães Rosa. Em seu monumental trabalho, a autora não incluiu os vocábulos de uso da língua comum, a menos que seu emprego fosse revestido de conotação especial, num esforço dedicado a definir a origem da opulência lexical rosiana, e ter, enfim, uma ideia do que, em Rosa, é patrimônio dicionarizado da língua, e o quanto é de sua inventiva, mas esclarece que: 
Para indicação mais exata do que é realmente sua inventiva, seria preciso um maior conhecimento do léxico de autores que o antecederam ou que foram de sua geração, a existência de um dicionário bem abrangente do português arcaico, outros de regionalismos, bem como vocabulários de escritores mais representativos da literatura de língua portuguesa. ${ }^{184}$

Em conferência proferida na Universidade de Santiago de Compostela, em 1989, afirmou que:

\begin{abstract}
Guimarães Rosa não teve, como muitos chegaram a dizer, a intenção ingênua de criar uma nova língua; o que ele pretendeu foi trazer ao brilho do seu estilo riquezas que exigiam paciente mineração em filões idiomáticos latentes ou esquecidos. Um dos resultados dessa busca nos estratos linguísticos foi o aproveitamento dos arcaísmos, quer remanescentes no falar que absorveu em sua infância passada no interior de Minas Gerais, quer respigados em textos ancestrais. Não é fácil, contudo, discernir os arcaísmos que se enquadram numa ou noutra fonte, dadas as deficiências de estudo dialetais brasileiros ou as lacunas dos glossários do português arcaico. $^{185}$
\end{abstract}

De acordo com Genouvrier e Peytard, o léxico contém características fundamentais em sua estrutura. Por não se disporem uniformemente, algumas palavras são mais frequentes que outras. ${ }^{186}$ No tratamento estatístico do léxico é importante fixarmos as noções de palavraschave e palavras-tema. Tais noções asseguram a precisão do método e traçam os limites das preferências linguísticas do autor, permitindo-nos caracterizar seu universo léxico e observarmos o desvio do seu universo vocabular em relação a outros autores.

Pierre Guiraud foi o mentor do objeto de estudos que deu um tratamento estatístico aos caracteres de um dado universo vocabular, utilizando a estatística a partir de um inventário exaustivo dos empregos, cujo resultado é um meio de sistematizar e objetivar tal inventário. O estudo da " frequência, atributo estatístico essencial da palavra na delimitação dos caracteres arritmo-semânticos do vocabulário" 187 começou a ser aprofundado pelo

\footnotetext{
${ }^{184}$ MARTINS, Nilce Sant`Anna. Arcaísmos em Guimarães Rosa e sua abonação em textos medievais, In: Actas do XIX Congresso Internacional de Linguística e Filoloxia Románicas, Universidade de Santiago de Compostela, 1989. Publicadas por Ramon Lourenço, p.737, 738.

${ }^{185}$ Ibid., 737, 738.

${ }^{186}$ GENOUVRIER, E; PEYTARD, J. Linguistica e Ensino de Português. Coimbra, Livraria Almedina, 1973. p 305 .

${ }^{187}$ ROBIN, R. História e Linguística. São Paulo, Editora Cultrix, 1977, p.137.
} 
laboratório de lexicometria da E.N.S. de Saint-Cloud, com base nas pesquisas de Charles Muller.

Índices de vários discursos como o de Robespierre e o de Saint-Just foram elaborados, manualmente, pela equipe "Revolução Francesa", do Centro de Lexicologia de Saint-Cloud.

Mostrando-se insuficientes tais trabalhos, com o advento da informática foram executados por programas de computadores.

Editando um "corpus" inventariado em um programa de indexação, podemos obter os índices alfabéticos e a frequência das formas lexicais e das formas funcionais por ordem de frequência decrescente. $O$ tratamento estatístico tem como produto a hierarquização das formas, da mais geral para a mais particular. Desse modo, as formas menos regularmente distribuídas, as formas mais específicas, distinguem-se do vocabulário geral, ou seja, as formas mais regularmente distribuídas.

Robin, no livro "História e Linguística", ainda cita P. Guiraud que, "após estabelecer a lista de frequência das "palavras de significação ou palavras fortes" de um "corpus", distingue três zonas arritmo-semânticas:

\begin{abstract}
1-As palavras-tema: cerca de cinquenta palavras (pode-se, se se quiser, tomar as primeiras 100 palavras, em vez das cinquenta primeiras: a determinação das 100 é relativamente arbitrária). As palavras-tema representam $9 \%$ do discurso. Geralmente são encontradas em todas as frases; quer dizer que é quase impossível exprimir uma ideia sem recorrer a elas. É em torno delas que se organiza o pensamento, donde seu nome de "palavras-tema", 2- As palavras de base, ou seja, as 4000 palavras que vêm em seguida, e que constituem a substância do discurso, 3) Finalmente, 20000 palavras de baixa frequência, de grande restrição de sentido, e portanto muito precisas. São denominadas "palavras de caracterização ${ }^{188}$.
\end{abstract}

A delimitação das três zonas arritmo-semântica em nosso trabalho se dará a partir da definição das palavras-chave do conjunto de palavras de obra analisada.

${ }^{188}$ ROBIN, Règine. História e Linguística. São Paulo, Cultrix, 1977, p. 141/143. 


\subsection{Etapas da pesquisa}

Para elegermos os vocábulos-termos a serem analisados, submetemos o corpus de análise à seleção das suas palavras-chave.

\subsubsection{Delimitação das unidades lexicais}

A escolha das palavras a serem analisadas de acordo com os objetivos de um trabalho é considerada um momento complexo e laborioso. Optamos, em nosso percurso, por selecionar as palavras de acordo com sua chavicidade. Nessa fase de delimitação das palavras, descartamos as palavras gramaticais, verbos e nomes próprios. Não podemos nos esquecer de que todas as palavras que aparecem nessa lista são palavras-chave definidas estatisticamente, ou seja, são todas típicas do corpus de análise. Do ponto de vista da frequência das palavras do corpus de Grande Sertão, estamos com P. Guiraud que afirmou que "a palavra criada por um indivíduo só tem valor na medida em que é aceita, retomada, repetida, sendo então finalmente definida pela soma de seus empregos" ${ }^{\prime 189}$.

$\mathrm{Na}$ primeira fase, observamos as palavras-chave e, como é natural, são as palavras gramaticais e os nomes próprios que predominam inicialmente. Passamos, então, a analisálas considerando o item chavicidade (keyness), que, de acordo com estudos, é considerado relevante a partir de 4,0. Podemos observar que o grau de chavicidade das palavras-chave no corpus de Grande Sertão é elevadíssimo (vide anexos) o que enfatiza, ainda uma vez, a característica peculiar do vocabulário do autor: são palavras que se afastam da frequência normal: "entende-se por palavra-chave qualquer palavra que, num dado corpus de subconjuntos, é característica de um ou de vários subconjuntos. Tal palavra tem lugar estatístico no subconjunto considerado, nitidamente superior ao seu lugar estatístico na lista de frequência do conjunto do corpus ${ }^{*}{ }^{190}$

Robin dá a medida da importância das experiências desenvolvidas pelo Centro de Lexicologia e Política de Saint-Cloud a cujos trabalhos nos referimos anteriormente e que se

\footnotetext{
${ }^{189}$ GUIRAUD, Pierre. Problèmes et méthodes de la statistique, Paris, Larousse, 1960, p. 19

${ }^{190}$ ROBIN, Règine. História e Linguística. São Paulo, Cultrix, 1977, p.143
} 
apoiam nos seguintes postulados: "o texto não é transparente; o recurso ao intuicionismo, à citação ilustrativa, à categoria temática são, por isso, condenados; o léxico não é considerado uma justaposição de termos sem relação entre si". ${ }^{191}$

Dessa forma, de acordo com Robin, há que se desestruturar o texto, por assim dizer, para recompô-lo em sua legibilidade significativa, observando a palavra nos vários contextos e empregos para, dessa forma, defini-la pela totalidade dos seus empregos e ligações daí resultantes. Ademais, não podemos nos esquecer de que o léxico é um sistema de relações de associações, oposições e identidades e não simplesmente uma listagem de palavras, daí a importância do agrupamento em campos léxico-semânticos. Partimos, portanto, do atributo essencial da palavra na delimitação dos caracteres arritmo-semânticos do vocabulário do corpus de análise, com o objetivo de estabelecer a lista de frequência das palavras-chave e a distinção das três zonas arritmo-semânticas: as palavras-tema, as palavras de base, as palavras de caracterização.

Enfim, erigido o conjunto das palavras definidas estatisticamente do ponto de vista da frequência, passamos a analisá-las no contexto, do qual escolhemos aquelas que possuem traços diferenciadores no universo da etnia sertaneja de Rosa. Observamos, em uma primeira análise, que algumas delas, assinaladas em negrito, já foram mencionadas em capítulos anteriores desta Dissertação, por portarem significado especial na realidade do sertanejo dos Gerais.

Dentre as palavras-chave selecionadas pelo programa do WordSmith Tools, no total de 2090 palavras, selecionamos as 100 palavras-tema (apenas substantivos comuns e adjetivos) que se situam entre as 341 primeiras palavras, ou seja, de acordo com Guiraud são as palavras essenciais para que o autor expresse a ideia em torno da qual gira a obra . Nesse conjunto estão os vocábulos-termos Deus, sertão, jagunço, vento, gerais, diabo, vereda e buriti, que analisaremos na ficha etnoterminológica.

\begin{tabular}{|c|c|c|c|c|c|c|c|}
\hline $\mathbf{N}$ & Key word & Freq. & $\%$ & $\begin{array}{l}\text { RC. } \\
\text { Freq. }\end{array}$ & RC. $\%$ & Keyness & $\mathbf{P}$ \\
\hline 4 & SENHOR & 878 & 0,459457338 & 483 & & 4742,156738 & $\begin{array}{r}7,66544 \mathrm{E}- \\
21\end{array}$ \\
\hline 6 & GENTE & 943 & 0,493471831 & 1062 & 0,01419394 & 4249,859375 & $\begin{array}{r}1,06766 \mathrm{E}- \\
20 \\
5,61492 \mathrm{E}-\end{array}$ \\
\hline 31 & HOMEM & 456 & 0,238624766 & 1874 & 0,02504655 & 1159,24939 & $\begin{array}{r}19 \\
\mathbf{1 , 3 0 9 7 8 E}-\end{array}$ \\
\hline 39 & SERTÃO & 160 & 0,083727986 & 79 & & 882,4592896 & 18 \\
\hline 43 & OLHOS & 242 & 0,126638576 & 672 & & 764,8655396 & $2,04917 \mathrm{E}-$ \\
\hline
\end{tabular}

${ }^{191}$ Ibid., p.153. 


$\begin{array}{rrrrrr}\text { JAGUNÇO } & \mathbf{9 2} & \mathbf{0 , 0 4 8 1 4 3 5 9 2} & \mathbf{0} & \\ \text { MÃO } & 258 & 0,135011375 & 1017 & 0,0135925 \\ \text { CAVALO } & 145 & 0,075878486 & 195 & \\ \text { MEDO } & 180 & 0,094193988 & 478 & \\ \text { CHEFE } & 168 & 0,087914385 & 472 & \\ \text { REPENTE } & 112 & 0,058609594 & 136 & \\ \text { FOGO } & 134 & 0,07012219 & 268 & \end{array}$

$\begin{array}{llll}\text { CAVALOS } & 119 & 0,06227269 & 179\end{array}$

$\begin{array}{llll}\text { DEUS } & 172 & 0,090007588 & 617\end{array}$

CHÃO $132 \quad 0,069075592 \quad 282$

HORA $195 \quad 0,102043487$

BANDA $\quad 98 \quad 0,051283393$

MENINO $117 \quad 0,061226092$

DEMO $\quad 65 \quad 0,034014497$

BEIRA $\quad 85 \quad 0,044480495$

LÉGUAS $\quad 59 \quad 0,030874696$

MAL $\quad 171 \quad 0,089484289$

NOITE $166 \quad 0,086867787$

BOM $217 \quad 0,113556087$

$\begin{array}{lll}\text { COMPADRE } & 58 & 0,030351397\end{array}$

CORAGEM $\quad 86 \quad 0,045003794$

JAGUNÇOS $53 \quad 0,027734896$

$\begin{array}{lll}\text { VEREDA } & 54 & \mathbf{0 , 0 2 8 2 5 8 1 9 7}\end{array}$

JEITO $113 \quad 0,059132893$

324

BALA $60 \quad 0,031397995$

25

HOMENS $184 \quad 0,096287183$

MUNIÇÃO $\quad 52 \quad 0,027211597$

1190

10

115

PÉ $\quad 116 \quad 0,060702793 \quad 402$

BOCA $106 \quad 0,055469792 \quad 312$
18

2,97438E-

$679,5025024 \quad 18$

$3,07026 \mathrm{E}-$

$672,7119751 \quad 18$

$4,0401 \mathrm{E}-$

$616,8623047 \quad 18$

$4,87594 \mathrm{E}-$

$581,4492798 \quad 18$

6,64233E-

$527,8441162 \quad 18$

$8,29375 \mathrm{E}-$

$492,6129456 \quad 18$

$8,35497 \mathrm{E}-$

$491,4901428 \quad 18$

$8,60536 \mathrm{E}-$

$487,0091248 \quad 18$

9,38526E-

474,096405 18

$9,59553 \mathrm{E}-$

$470,8580627 \quad 18$

$1,05425 \mathrm{E}-$

$0,01212232 \quad 457,3659058 \quad 17$

$1,20178 \mathrm{E}-$

$439,27948 \quad 17$

1,2819E-

$430,654541 \quad 17$

$1,54193 \mathrm{E}-$

$406,9714355 \quad 17$

$1,60718 \mathrm{E}-$

$401,8535461 \quad 17$

$1,61952 \mathrm{E}-$

$400,9168701 \quad 17$

$1,70305 \mathrm{E}-$

$0,01087934 \quad 394,8172607 \quad 17$

$1,94153 \mathrm{E}-$

$379,3942261 \quad 17$

$2,01405 \mathrm{E}-$

$375,1981812 \quad 17$

2,13968E-

$368,3850098 \quad 17$

$2,28176 \mathrm{E}-$

$361,2953491 \quad 17$

2,36021E-

$357,6280518 \quad 17$

2,40274E-

$355,7073364 \quad 17$

$2,50186 \mathrm{E}-$

$351,4014587 \quad 17$

$2,75358 \mathrm{E}-$

$341,4190369 \quad 17$

$2,87578 \mathrm{E}-$

$337,0016479 \quad 17$

3,09171E-

$329,7766724 \quad 17$

3,17858E-

$327,0570068 \quad 17$

3,2116E-

$326,0493164 \quad 17$

$325,2620239 \quad 3,23771 \mathrm{E}-$ 
124
BURITI

AMOR $\quad 120 \quad 0,062795989$

450

ARMAS $102 \quad 0,053376593 \quad 293$

RIFLE $\quad 45 \quad 0,023548497 \quad 2$

$\begin{array}{llll}\text { BOI } & 67 & 0,035061095 & 65\end{array}$

$\begin{array}{llll}\text { RAIVA } & 68 & 0,035584394 & 92\end{array}$

$\begin{array}{llll}\text { AMIGO } & 99 & 0,051806692 & 370\end{array}$

$\begin{array}{llll}\text { PADRINHO } & 40 \quad 0,020931996 \quad 5\end{array}$

$\begin{array}{llll}\text { CAPIM } & 51 & 0,026688296 & 40\end{array}$

$\begin{array}{llll}\text { BANDO } & 48 & 0,025118396\end{array}$

$\begin{array}{llll}\text { VAQUEIRO } & 40 & 0,020931996 & 13\end{array}$

$\begin{array}{llll}\text { FACA } & 48 \quad 0,025118396 & 39\end{array}$

$\begin{array}{llll}\text { CARA } & 100 \quad 0,052329995 & 467\end{array}$

$\begin{array}{llll}\text { ALEGRIA } & 69 & 0,036107697 & 170\end{array}$

$\begin{array}{llll}\text { RUMO } & 71 \quad 0,037154295 & 188\end{array}$

CHAPADÃO $\quad 36 \quad 0,018838797$

VENTO $73 \quad \mathbf{0 , 0 3 8 2 0 0 8 9 6}$

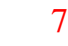

214

$\begin{array}{llll}\text { TRISTEZA } & 51 \quad 0,026688296 & 66\end{array}$

$\begin{array}{llll}\text { FORTE } & 128 & 0,066982388 & 954\end{array}$

ÓDIO $\quad 52 \quad 0,027211597 \quad 89$

$\begin{array}{llll}\text { BALAS } & 37 \quad 0,019362098 & 19\end{array}$

$\begin{array}{llll}\text { TIRO } & 49 & 0,025641697 & 75\end{array}$

$\begin{array}{llll}\text { COURO } & 46 & 0,024071796 & 61\end{array}$

$\begin{array}{lll}\text { CORAÇÃO } \quad 89 \quad 0,046573695 & 455\end{array}$

$\begin{array}{llll}\text { COSTAS } & 64 & 0,033491194 & 192\end{array}$

$\begin{array}{llll}\text { AR } & 118 & 0,061749391 & 874\end{array}$

$\begin{array}{llll}\text { LIGEIRO } & 37 & 0,019362098 & 28\end{array}$

CÉU $\quad 76 \quad 0,039770793 \quad 333$

$\begin{array}{llll}\text { VELHO } & 88 & 0,046050392 & 481\end{array}$

VALENTE $\quad 40 \quad 0,020931996$ $\mathbf{3 2 4 , 2 9 3 6 0 9 6} 17$

$3,33838 \mathrm{E}-$

$322,3044739 \quad 17$

3,53362E-

$316,8937683 \quad 17$

$3,5706 \mathrm{E}-$

$315,9137573 \quad 17$

$3,59926 \mathrm{E}-$

$315,1634216 \quad 17$

4,84301E-

$288,678009 \quad 17$

6,3718E-

$266,4213562 \quad 17$

$6,55099 \mathrm{E}-$

$264,2825012 \quad 17$

$7,52677 \mathrm{E}-$

$253,8672485 \quad 17$

$8,94157 \mathrm{E}-$

$241,5990753 \quad 17$

$9,55908 \mathrm{E}-$

$237,0289307 \quad 17$

9,59092E-

$236,8040161 \quad 17$

$1,00187 \mathrm{E}-$

$233,8756256 \quad 16$

$1,04767 \mathrm{E}-$

230,9190979 16

$1,06842 \mathrm{E}-$

$229,6360931 \quad 16$

$1,09521 \mathrm{E}-$

$228,0279083 \quad 16$

224,4555206 1,158E-16

$1,24866 \mathrm{E}-$

$219,7301331 \quad 16$

$1,54925 \mathrm{E}-$

$0,01275048 \quad 206,8448944 \quad 16$

$1,66035 \mathrm{E}-$

$202,9002686 \quad 16$

$1,67271 \mathrm{E}-$

$202,4831848 \quad 16$

$1,77212 \mathrm{E}-$

$199,2719879 \quad 16$

$1,86117 \mathrm{E}-$

$196,5927887 \quad 16$

$1,9001 \mathrm{E}-$

$195,4746399 \quad 16$

$1,9366 \mathrm{E}-$

$194,4539337 \quad 16$

2,03648E-

$0,01168126 \quad 191,7865753 \quad 16$

2,2861E-

$185,8208618 \quad 16$

2,3058E-

$185,3874054 \quad 16$

$2,36716 \mathrm{E}-$

$184,0678558 \quad 16$

$2,37436 \mathrm{E}-$

$183,9159241 \quad 16$ 


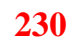

233

234

240

243

248

250

252

253

254

260

263

264

266

267

269

270

271

274

275

276

277

280

287

289

290

304

308

309

310

\section{DIABO}

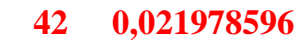

TIROS

$46 \quad 0,024071796$

BEIRAS

$27 \quad 0,014129099$

$\begin{array}{lll}\text { SELA } & 29 & 0,015175698\end{array}$

CÃO

$42 \quad 0,021978596$

SAUDADE $\quad 37 \quad 0,019362098$

CHAPÉU $\quad 37 \quad 0,019362098$

AMIZADE $\quad 51 \quad 0,026688296$

ESCURO $\quad 48 \quad 0,025118396$

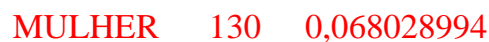

LÉGUA $\quad 22 \quad 0,011512598$

DEMÔNIO $32 \quad 0,016745597$

MOÇA $\quad 43 \quad 0,022501897$

CATRUMANOS

$21 \quad 0,010989298$

RIBA $21 \quad 0,010989298$

MOÇO

DOIDO

31

0,016222298

$25 \quad 0,013082499$

PAZ $71 \quad 0,037154295$

$\begin{array}{lll}\text { CALADO } \quad 32 & 0,016745597\end{array}$

PADRE

MANO

$42 \quad 0,021978596$

ORDENS

$33 \quad 0,017268898$

$45 \quad 0,023548497$

INIMIGO

$50 \quad 0,026164997$

$\begin{array}{lll}\text { CABRAS } & 24 & 0,012559198\end{array}$

ALMA $\quad 57 \quad 0,029828096$

$\begin{array}{llll}\text { FAZENDA } & 76 & 0,039770793 & 461\end{array}$

$\begin{array}{llll}\text { BONDADE } & 23 & 0,012035898 & 6\end{array}$

$\begin{array}{llll}\text { CAVALEIROS } & 24 & 0,012559198 & 9\end{array}$

$\begin{array}{llll}\text { PAREDÃO } & 24 & 0,012559198 & 9\end{array}$

ÉGUA $26 \quad 0,013605799$
29

85

34

229

53

78

3

8

62

40

41

132

110

1229

0

25

86

0

0

24

6

368

29

85

108

151

6

9

1

6

9

9

15
2,44548E-

$182,4482422 \quad 16$

$2,56396 \mathrm{E}-$

$180,1255646 \quad 16$

$2,5676 \mathrm{E}-$

$180,0565796 \quad 16$

$2,79686 \mathrm{E}-$

$175,9514313 \quad 16$

$2,9776 \mathrm{E}-$

$173,0191345 \quad 16$

$3,27643 \mathrm{E}-$

$168,6572418 \quad 16$

3,36921E-

$167,4096832 \quad 16$

$3,41889 E-$

$166,7603607 \quad 16$

$3,47671 \mathrm{E}-$

$166,0202026 \quad 16$

$3,57613 \mathrm{E}-$

$0,01642594 \quad 164,7852478 \quad 16$

$3,77194 \mathrm{E}-$

$162,4818726 \quad 16$

4,05279E-

$159,4427185 \quad 16$

$4,2266 \mathrm{E}-$

$157,6990051 \quad 16$

4,50504E-

$155,0962219 \quad 16$

4,50504E-

$155,0962219 \quad 16$

4,53706E-

$154,8106384 \quad 16$

$4,57461 \mathrm{E}-$

$154,4791718 \quad 16$

4,58301E-

$154,4054871 \quad 16$

4,70154E-

$153,3850403 \quad 16$

4,71459E-

$153,274826 \quad 16$

$4,79886 \mathrm{E}-$

$152,5725098 \quad 16$

$4,8166 \mathrm{E}-$

$152,4267578 \quad 16$

4,94524E-

$151,3908081 \quad 16$

$5,46688 \mathrm{E}-$

$147,5316467 \quad 16$

$5,56528 \mathrm{E}-$

$146,8585358 \quad 16$

$5,59347 \mathrm{E}-$

$146,6685944 \quad 16$

6,60402E-

$140,6008148 \quad 16$

6,90395E-

$139,0342255 \quad 16$

$6,90395 \mathrm{E}-$

$139,0342255 \quad 16$

$6,92441 \mathrm{E}-$

$138,9306641 \quad 16$ 


$\begin{array}{rrrrrrrr}313 & \text { ARRAIAL } & 25 & 0,013082499 & 12 & & 138,617691 & 6,98674 \mathrm{E}- \\ & & & & & & & 16 \\ 316 & \text { FRIO } & 47 & 0,024595097 & 151 & & 137,719574 & 7,16981 \mathrm{E}- \\ & & & & & & & 7,98657 \mathrm{E}- \\ 319 & \text { GUERRA } & 127 & 0,06645909 & 1398 & 0,01868467 & 134,056015 & 16 \\ 324 & \text { VIDA } & 246 & 0,128731787 & 4115 & 0,05499816 & 132,058136 & 8,48475 \mathrm{E}- \\ & & & & & & & \mathbf{9 , 7 8 9 7 7 \mathrm { E } -} \\ \mathbf{3 4 1} & \text { GERAIS } & \mathbf{9 6} & \mathbf{0 , 0 5 0 2 3 6 7 9 1} & \mathbf{8 7 0} & \mathbf{0 , 0 1 1 6 2 7 8} & \mathbf{1 2 7 , 4 9 1 5 6 9 5} & \mathbf{1 6}\end{array}$

As palavras-tema escolhidas aleatoriamente (em negrito na lista acima) são palavras de uso da língua geral que, elaboradas culturalmente, possuem especificidades semânticas que não se aplicam à cultura urbana e, ao ouvinte, resta a surpresa do vocábulo-termo que se apresenta com exclusividades semânticas advindas de uma visão humana particular, estabelecida no universo antropocultural. Trata-se, portanto, como temos dito ao longo desta pesquisa, de palavras utilizadas por um grupo linguístico que constrói semioticamente sua realidade, a realidade do sertanejo do sertão dos gerais.

Nesse primeiro grupo, podemos observar palavras de caracterização temática, que nos discursos etnoliterários, como já observamos anteriormente, funcionam como suporte aos tipos humanos, no caso o jagunço, o catrumano e o urucuiano rosianos, abordando dois grandes temas universais que se opõem dialeticamente: Deus e diabo e ainda sertão e vereda, que também se enfrentam dialeticamente ao longo da obra.

Os elementos de crença e superstição são evocados através do tipo humano, também ele temático: o jagunço (homem temente a Deus, que age sob ordens endemoniadas de um chefe).

Optamos, ainda, por analisar as seguintes palavras de base, que de acordo com Guiraud constituem a substância do discurso e que também foram escolhidas aleatoriamente: porto , urucuiano, venda, dobros, jacuba, resfriado, zureta, e as palavras de baixa frequência, pertencentes ao conjunto das palavras-chave definidas pelo programa Wordsmith Tools, de grande restrição de sentido, que são as seguintes: januária, redemoinho, caborje, catrumanos, arco-íris, rastreador, tombador, croa-com-ilha, catrumanos, quizília, cabaça bem tapada e breada.

Podemos concluir que, em relação à frequência, a menor ocorrência de uma palavra a distingue das demais unidades léxicas da língua geral, como característica do grupo linguístico a que pertence. Isto nos remete à afirmação de Saussure de que a língua é o fator mais importante e necessário a compor o vínculo a que chama etnismo. Poucas linhas do universo de discurso rosiano nos dá a certeza do grupo linguístico a que pertence. 


\subsubsection{A ficha etnoterminológica}

Concebemos uma ficha de análise de cada vocábulo-termo, nela registrando o número de cada termo, em ordem decrescente em relação à frequência de ocorrências no corpus de Grande Sertão, da mais frequente para a menos frequente; em seguida acrescentamos o vocábulo a ser analisado, e sua origem, conforme registrada em dicionários. Há um primeiro campo no qual registramos o significado da palavra pesquisada em dicionários atuais da língua portuguesa (Houaiss on line e o Novo Aurélio em sua versão impressa), e em dicionários antigos on line (Bluteau, Silva Pinto, Moraes Silva), da biblioteca Brasiliana, da USP, bem como no dicionário impresso de Nilce S. Martins e na obra de Nei Leandro de Castro.

Reservamos um campo para os contextos nos quais aparecem as palavras em Grande Sertão, escolhendo, no caso de palavras muito frequentes, aquelas próprias à nossa análise. No caso de vocábulos menos frequentes, registrando todas as suas ocorrências, quando pertinentes.

Seguem-se dois campos: o primeiro de análise da natureza dos semas conceptuais formadores do vocábulo-termo (que permitem analisarmos a intenção da manifestação linguística), e o segundo, de levantamento dos semas (que nos permite compreender a construção do sentido) considerando, para efeito de comparação entre os universos de discursos da língua geral e do universo de discurso etnoliterário, os semas distintivos formadores do vocábulo-termo à luz dos dicionários e dos contextos selecionados no corpus.

Finalmente, no último campo, passamos à definição do vocábulo-termo (expansão do conteúdo conceptual). Ao final de cada ficha procedemos, quando possível, a observações gerais que contextualizam o vocábulo-termo em seus aspectos próprios. 
Ficha Etnoterminológica $n^{\circ} \quad$ Vocábulo-termo: Ocorrências:

Significado no dicionário

Contextualizações:

\begin{tabular}{|l|l|l|l|}
\hline NATUREZA & Classe de Noemas & $\begin{array}{l}\text { Caracterização Semântico- } \\
\text { Conceptual }\end{array}$ & Natureza \\
$\begin{array}{l}\text { SEMAS } \\
\text { CONCEPTUAIS }\end{array}$ & Conceptus & & \\
\cline { 2 - 4 } & Metaconceptus & & \\
\cline { 2 - 4 } & Metametaconceptus & & \\
\hline
\end{tabular}

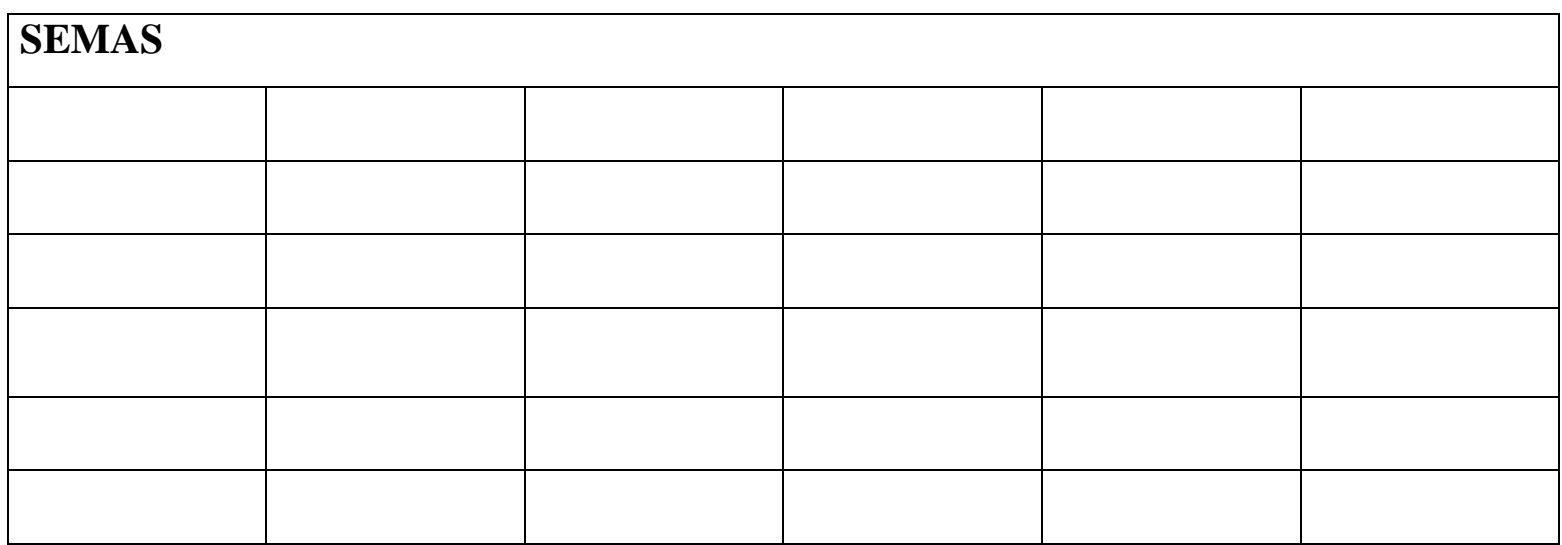

Definição do vocábulo-termo

Observações: 


\section{ANÁLISE DOS VOCÁBULOS -TERMOS: FORMAÇÃO CONCEITUAL}

As palavras aqui selecionadas caracterizam, em boa parte, o tipo humano sertanejo, eivado de misticismo (jagunço, catrumano, urucuiano, rastreador e ainda, zureta e caborje, que podem adjetivá-los); o espaço e acidentes geográficos de feição ímpar (sertão, gerais, veredas, resfriado, croa-com-ilha, tombador e ainda, porto e venda, que compõem elementos de valor cultural e social); os elementos da natureza que ornam o espaço e a imaginação do geralista (vento, redemoinho, buritis, arco-íris), suas crenças resumidas entre o bem e o mal (Deus, diabo) e o seu cotidiano (januária, dobro, cabaça bem tapada e breada, quizília). São palavras que definem a axiologia do grupo e o mundo semioticamente construído por Rosa. Além disso, redefinem o léxico que utilizamos (o do leitor-ouvinte), pelo processo de ressemantização da palavra usada na língua geral. São palavras de uso em língua geral que se constituem em signos-símbolos em Grande Sertão: Veredas, como demonstra a análise do vocábulo-termo sertão, no recorte conceptual abaixo:

Campo semântico-conceptual

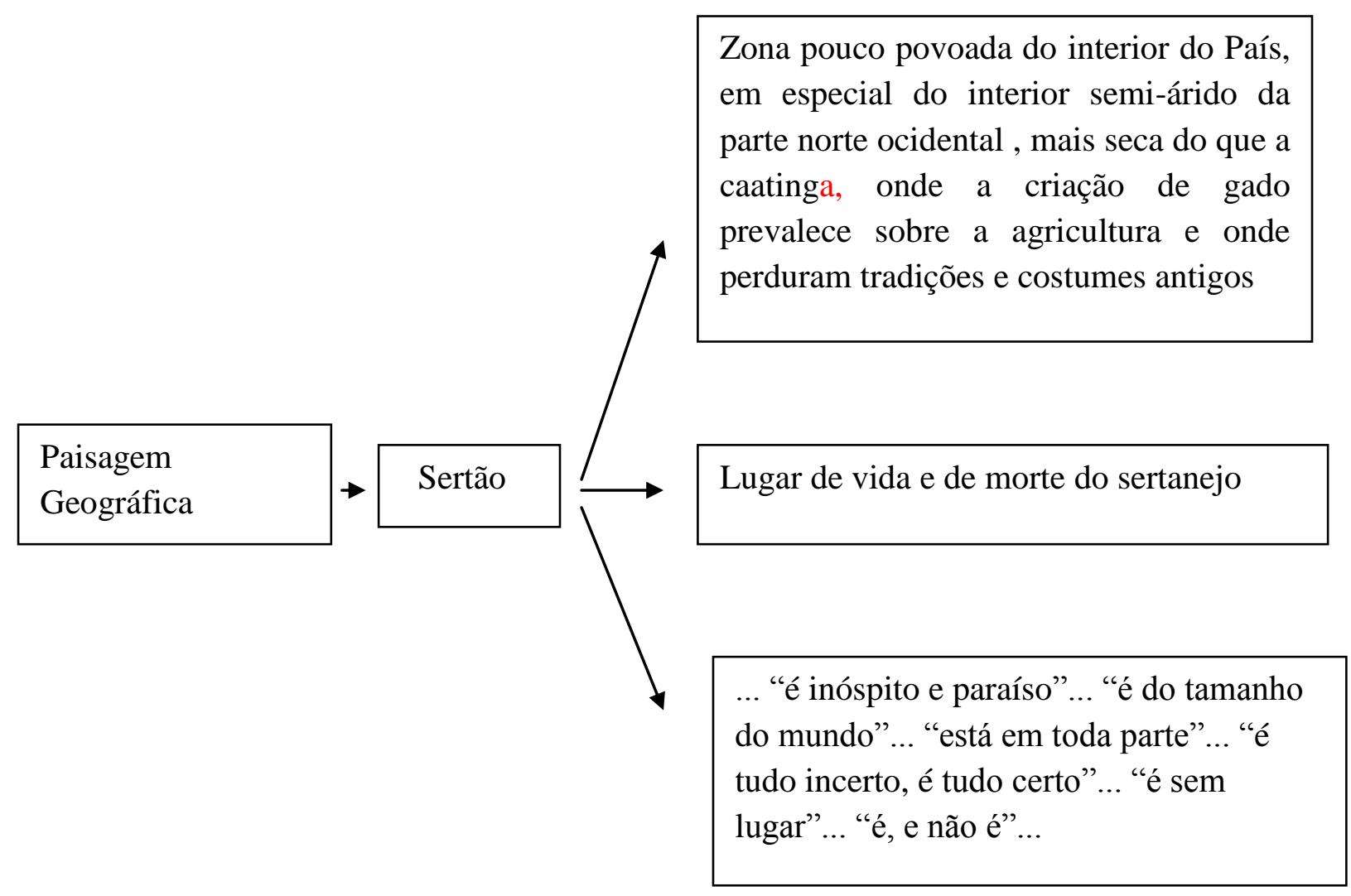


Significado no dicionário Houaiss: Rubrica: religião: Ente infinito, eterno, sobrenatural e existente por si só; causa necessária e fim último de tudo que existe. Nas religiões primitivas, designação dada às forças ocultas, aos espíritos mais ou menos personalizados. Nas religiões monoteístas, sobretudo no cristianismo, ser supremo, criador do universo. Catolicismo: cada uma das três pessoas distintas existentes em um só Deus (Pai, Filho e Espírito Santo).

Contextualizações:1) Deus é paciência. O contrário, é o diabo. p.6; 2) o diabo, é às brutas; mas Deus é traiçoeiro! p.8; 3) Deus vem vindo: ninguém não vê. Ele faz é na lei do mansinho - assim é o milagre. E Deus ataca bonito, se divertindo, se economiza.p.8; 4) Deus é definitivamente; o demo é o contrário Dele.p.17; 5) aquilo mesmo que a gente receia de fazer quando Deus manda, depois quando o diabo pede se perfaz.p.19; 6) Deus come escondido, e o diabo sai por toda parte lambendo o prato.p.24; 7) Deus existe mesmo quando não há. Mas o demônio não precisa de existir para haver. p. 26; 8) Deus vem, guia a gente por uma légua, depois larga.p.65; 9) Deus governa grandeza. p.70; 10) tive medo de castigo de Deus. p.91; 11) Deus a gente respeita, do demônio se esconjura e aparta.p.101; 12) Deus, para qualquer um jagunço, sendo um inconstante patrão, que às vezes regia ajuda, mas, outras horas, sem espécie nenhuma, desandava de lá.p.106; 13) Deus é pque deixa se afinar à vontade o instrumento, até que chegue a hora de se dansar.p.141; 13) Mas eu hoje em dia acho que Deus é alegria e coragem - que Ele é bondade adiante, quero dizer. p.143.

\begin{tabular}{|l|l|l|l|}
\hline $\begin{array}{l}\text { NATUREZA } \\
\text { DOS }\end{array}$ & Classe de Noemas & Caracterização Semântico - Conceptual & Natureza \\
$\begin{array}{l}\text { SEMAS } \\
\text { FORMADORES }\end{array}$ & Conceptus & $\begin{array}{l}\text { Ser supremo, criador do universo, que } \\
\text { governa e ninguém vê. }\end{array}$ & $\begin{array}{l}\text { Traços sócio- } \\
\text { culturais }\end{array}$ \\
\cline { 2 - 4 } & Metaconceptus & $\begin{array}{l}\text { O contrário do demo, definitivamente, na lei } \\
\text { do mansinho. }\end{array}$ & $\begin{array}{l}\text { Traços culturais } \\
\text { ideológicos }\end{array}$ \\
\cline { 2 - 4 } & Metametaconceptus & $\begin{array}{l}\text { Alegria e coragem, patrão inconstante que } \\
\text { deixa afinar à vontade o instrumento, guia a } \\
\text { gente por uma légua e depois larga. }\end{array}$ & $\begin{array}{l}\text { Traços culturais } \\
\text { modalizantes } \\
\text { intencionais }\end{array}$ \\
\hline
\end{tabular}

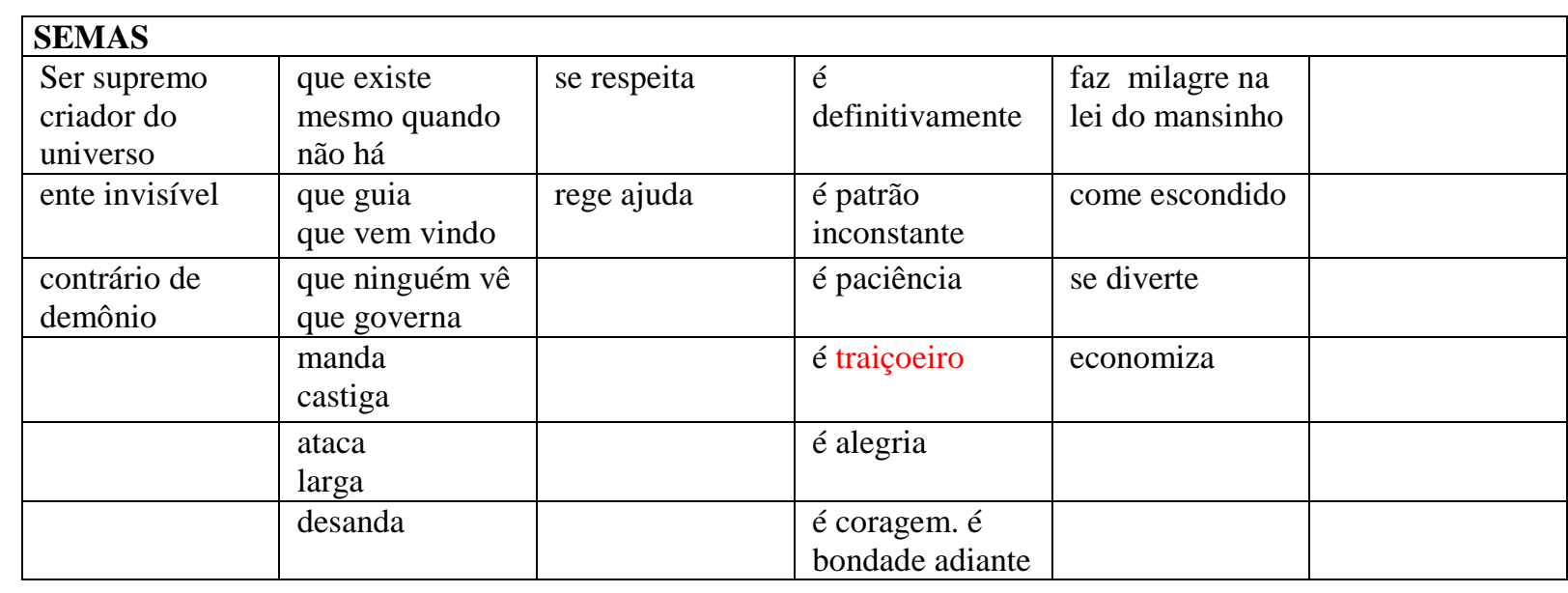

Definição do vocábulo-termo DEUS: Patrão inconstante, é bondade adiante, existe mesmo quando não há e na lei do mansinho guia a gente por uma légua e depois larga; é definitivamente alegria e coragem. 
Significado no dicionário Houaiss: Região agreste, afastada dos núcleos urbanos e das terras cultivadas. Terreno coberto de mato, afastado do litoral. Terra e a povoação do interior; o interior do país. Regionalismo: Brasil. toda região pouco povoada do interior, em especial, a zona mais seca que a caatinga, ligada ao ciclo do gado e onde permanecem tradições e costumes antigos.

Contextualizações1) [...]situado sertão é por os campos-gerais a fora a dentro... Lugar sertão se divulga: é onde os pastos carecem de fechos; onde um pode torar dez, quinze léguas, sem topar com casa de morador; e onde criminoso vive seu cristojesus, arredado do arrocho de autoridade p.1;2) Sertão é onde o pensamento da gente se forma mais forte do que o poder do lugar.p.1; 3 ) Treva toda do sertão, sempre me fez mal.p.13; 4) No sertão, até enterro simples é festa.p.25; 5) O sertão é do tamanho do mundo.p.32; 6) Lhe falo do sertão. Do que não sei. Um grande sertão! Não sei. Ninguém ainda não sabe. Só umas raríssimas pessoas - e só essas poucas veredas, veredazinhas.p.44; 7) No centro do sertão, o que é doideira às vezes pode ser a razão mais certa e de mais juízo! p.130; 8 ) Sertão é isto: o senhor empurra para trás, mas de repente ele volta a rodear o senhor dos lados; 9) O sertão tem medo de tudo.p.143; 10) Desde o raiar da aurora, o sertão tonteia. Os tamanhos. A alma deles.p.144; 11) O sertão aceita todos os nomes: aqui é o Gerais, lá é o Chapadão, lá acolá é a caatinga.p.225; 12) O sertão não tem janelas nem portas. E a regra é assim: ou o senhor bendito governa o sertão, ou o sertão maldito vos governa p.228; 13) Só que o sertão é grande ocultado demais.p.232; 14) O sertão não chama ninguém às claras; mais, porém, se esconde e acena. Mas o sertão de repente se estremece, debaixo da gente...p.240;

\begin{tabular}{|c|c|c|c|}
\hline \multirow{4}{*}{$\begin{array}{l}\text { NATUREZA } \\
\text { DOS } \\
\text { SEMAS } \\
\text { CONCEPTUAIS } \\
\text { FORMADORES }\end{array}$} & Classe de Noemas & Caracterização Semântico-Conceptual & Natureza \\
\hline & Conceptus & $\begin{array}{l}\text { Região do interior do Brasil, pouco habitada, e } \\
\text { pouco conhecida, afastada dos núcleos urbanos, } \\
\text { onde perduram tradições e costumes antigos. }\end{array}$ & Traços biofísicos \\
\hline & Metaconceptus & $\begin{array}{l}\text { Região do tamanho do mundo, arredada de } \\
\text { arrocho de autoridade, ocultada, onde enterro é } \\
\text { festa, o raiar da aurora tonteia e a treva faz mal. }\end{array}$ & $\begin{array}{l}\text { Traços culturais } \\
\text { ideológicos }\end{array}$ \\
\hline & Metametaconceptus & $\begin{array}{l}\text { Lugar que esconde, acena e rodeia por todos os } \\
\text { lados, onde se tem medo de tudo, o pensamento } \\
\text { se forma mais forte que o poder do lugar e a } \\
\text { doideira pode ser razão e juízo. }\end{array}$ & $\begin{array}{l}\text { Traços culturais } \\
\text { modalizantes } \\
\text { intencionais }\end{array}$ \\
\hline
\end{tabular}

\begin{tabular}{|c|c|c|c|c|c|c|}
\hline \multicolumn{7}{|l|}{ SEMAS } \\
\hline $\begin{array}{l}\text { região do } \\
\text { interior do } \\
\text { Brasil Central }\end{array}$ & $\begin{array}{l}\text { se estende } \\
\text { pelos campos } \\
\text { gerais }\end{array}$ & $\begin{array}{l}\text { do tamanho } \\
\text { do mundo }\end{array}$ & sem casas & $\begin{array}{l}\text { onde pastos } \\
\text { carecem de } \\
\text { fechos }\end{array}$ & se esconde & $\begin{array}{l}\text { lugar que } \\
\text { ninguém } \\
\text { ainda não } \\
\text { sabe }\end{array}$ \\
\hline \multirow[t]{5}{*}{$\begin{array}{l}\text { zona pouco } \\
\text { habitada do } \\
\text { interior do } \\
\text { país }\end{array}$} & $\begin{array}{l}\text { pelas } \\
\text { chapadas }\end{array}$ & grande & $\begin{array}{l}\text { arredado do } \\
\text { arrocho de } \\
\text { autoridade }\end{array}$ & $\begin{array}{l}\text { onde até } \\
\text { enterro } \\
\text { simples é } \\
\text { festa }\end{array}$ & acena & $\begin{array}{l}\text { lugar que só } \\
\text { umas } \\
\text { raríssimas } \\
\text { pessoa sabem }\end{array}$ \\
\hline & $\begin{array}{l}\text { pelos } \\
\text { chapadões }\end{array}$ & ocultado & $\begin{array}{l}\text { sem janelas } \\
\text { nem portas }\end{array}$ & $\begin{array}{l}\text { onde doideira } \\
\text { pode ser } \\
\text { razão }\end{array}$ & estremece & $\begin{array}{l}\text { lugar que só } \\
\text { essas poucas } \\
\text { veredas } \\
\text { sabem }\end{array}$ \\
\hline & pela caatinga & & & $\begin{array}{l}\text { onde o } \\
\text { pensamento } \\
\text { se forma mais } \\
\text { forte }\end{array}$ & governa & $\begin{array}{l}\text { lugar que só } \\
\text { essas } \\
\text { veredazinhas } \\
\text { sabem }\end{array}$ \\
\hline & $\begin{array}{l}\text { a fora a } \\
\text { dentro }\end{array}$ & & & $\begin{array}{l}\text { onde treva } \\
\text { toda faz mal }\end{array}$ & $\begin{array}{l}\text { empurra } \\
\text { tonteia }\end{array}$ & \\
\hline & & & & & $\begin{array}{l}\text { volta } \\
\text { rodeia }\end{array}$ & \\
\hline
\end{tabular}

Definição do vocábulo-termo SERTÃO: Cerrados e campos-gerais do tamanho do mundo, arredado de arrocho de autoridade, sem janelas nem portas, que raríssimas e poucas veredas sabem, e de repente se estremece debaixo da gente, esconde, acena e rodeia por todos os lados, onde o pensamento fica mais forte e doideira pode ser razão e juízo.

Observações: Em carta de 19/11/63, Rosa relembra ao tradutor italiano: "No sertão a magia é inseparável de todos os aspectos da vida" p.81. Em C. Proença: "Tudo é sertão - savanas e campos-gerais para os botânicos, cerrados e campos-gerais para os sertanejos" p. 30. 
Significado no dicionário Houaiss: Regionalismo: Brasil Criminoso Cangaceiro, foragido ou qualquer homem violento contratado como guarda-costas por indivíduo influente (p.ex., fazendeiro, senhor de engenho, político) e por este homiziado.2 Regionalismo: Bahia. Seguidor de Antônio Conselheiro (1828-1897), chefe religioso da rebelião de Canudos.

Contextualizações: 1) quem de si de ser jagunço se entrete, já é por alguma competência entrante do demônio.p.2/ 2) jagunço não é muito de conversa continuada nem de amizades estreitas: a bem eles se misturam e desmisturam, de acaso, mas cada um é feito um por si.p.11/ 3) Jagunço é homem já meio desistido por si...p.21/ 4) Jagunço não se escabreia com perda nem derrota - quase que tudo para ele é o igual.p.24/ 5) [...] tudo num homem-d'armas, brabo bem jagunço - eu não entendia! p.64/65/ 6) Homem é rosto a rosto; jagunço também: é no quem-com-quem.p.72/ 7) [...] eu Riobaldo, jagunço, homem de matar e morrer com a minha valentia. Riobaldo, homem, eu, sem pai, sem mãe, sem apego nenhum, sem pertencências.p.91/ 8) Jagunço - criatura paga para crimes, impondo o sofrer no quieto arruado dos outros, matando e roupilhando. p.100/ 9) Lei de jagunço é o momento, o menos luxos.p.122/ 10) [...] que, jagunço, pelo que é, quase que nunca pensa em reto:p.125/ 11) Mas morrer em combate é coisa trivial nossa; para que é que a gente é jagunço?! Quem vai em caça, perde o que não acha...”p.126/ 12) sensato se dizia. Que jagunço amolece, quando não padece.p.134/ 13) Ah, jagunço não despreza quem dá ordens diabradas p.233/ 14) É de ver que não esquentamos lugar na redondez, mas viemos contornando - só extorquindo vantagens de dinheiro, mas sem devastar nem matar - sistema jagunço. p. 238/ 15) Discutido assim, o pessoal se arrumou para ir, já indo; jagunço nunca dilata. p.253/16) Falo o dito de jagunço: que eles mesmos não conseguiam saber se tinham algum medo; mas, em morte, nenhum deles pensava. p. 254/ 17) Alegria do jagunço é o movimento galopado. p. 260/ 18) Não podendo entender a razão da vida, é só assim que se pode ser vero bom jagunço...p.263/ 19) Ninguém nunca foi jagunço obrigado. p. 265.

\begin{tabular}{|c|c|c|c|}
\hline \multirow{4}{*}{$\begin{array}{l}\text { NATUREZA } \\
\text { DOS } \\
\text { SEMAS } \\
\text { CONCEPTUAIS } \\
\text { FORMADORES }\end{array}$} & Classe de Noemas & Caracterização Semântico-Conceptual & Natureza \\
\hline & Conceptus & $\begin{array}{l}\text { Homem valente, bravo, pago para } \\
\text { cometer crimes. }\end{array}$ & $\begin{array}{l}\text { Traços biofísicos sócio- } \\
\text { psico-culturais }\end{array}$ \\
\hline & Metaconceptus & $\begin{array}{l}\text { Criatura sem pertencências, sem medo da } \\
\text { morte, que obedece ordens do diabo e é } \\
\text { jagunço por sua própria vontade. }\end{array}$ & $\begin{array}{l}\text { Traços culturais } \\
\text { ideológicos }\end{array}$ \\
\hline & Metametaconceptus & $\begin{array}{l}\text { Homem misterioso que se rege pelo } \\
\text { demônio, não entende a razão da vida e } \\
\text { por isso já é desistido de si. }\end{array}$ & $\begin{array}{l}\text { Traços culturais } \\
\text { modalizantes intencionais }\end{array}$ \\
\hline
\end{tabular}

\begin{tabular}{|l|l|l|l|l|l|}
\hline \multicolumn{2}{|l|}{ SEMAS } & $\begin{array}{l}\text { pago para } \\
\text { crimes } \\
\text { d'armas brabo } \\
\text { sem mãe }\end{array}$ & $\begin{array}{l}\text { não é jagunço } \\
\text { obrigado }\end{array}$ & $\begin{array}{l}\text { é o momento, } \\
\text { não é de } \\
\text { conversar }\end{array}$ & $\begin{array}{l}\text { se rege por modo } \\
\text { encoberto }\end{array}$ \\
\hline $\begin{array}{l}\text { de matar e } \\
\text { morrer; }\end{array}$ & sem apego & & $\begin{array}{l}\text { não pensa em } \\
\text { reto }\end{array}$ & $\begin{array}{l}\text { não é de ter } \\
\text { amizade }\end{array}$ & $\begin{array}{l}\text { se rege por modo } \\
\text { custoso }\end{array}$ \\
\hline de roupilhar & desistido de si & & & é o menos luxos & arredio \\
\hline $\begin{array}{l}\text { de impor o } \\
\text { sofrer }\end{array}$ & $\begin{array}{l}\text { sem } \\
\text { pertencências }\end{array}$ & & $\begin{array}{l}\text { valente } \\
\text { endemoniado }\end{array}$ & misterioso \\
\hline $\begin{array}{l}\text { de morrer em } \\
\text { combate }\end{array}$ & $\begin{array}{l}\text { sem } \\
\text { pensamento de } \\
\text { morte }\end{array}$ & $\begin{array}{l}\text { feito por si é no } \\
\text { quem-com-quem }\end{array}$ & \\
\hline $\begin{array}{l}\text { de obedecer } \\
\text { semdens } \\
\text { diabradas } \\
\text { da razão da } \\
\text { vida }\end{array}$ & & & & & \\
\hline
\end{tabular}

Definição do vocábulo-termo JAGUNÇO: Criatura valente feita por si no quem é quem, sem entendimento da vida, não pensa em reto, é de impor o sofrer, sem pertencências, se rege por modo encoberto e é pago para obedecer ordens do diabo e cometer crimes por sua própria vontade.

Observações: "Observa Wilson Lins que o jagunço é homem temente à lei, que só pega em armas sob a responsabilidade de um chefe" Arroyo, p.89 
Significado no dicionário Houaiss: s.m. Mistura gasosa que forma a atmosfera, constituída principalmente de nitrogênio (78 \%) e oxigênio (21\%);atmosfera, fluido gasoso que envolve a Terra, constituído da combinação de vários gases. Derivação: por extensão de sentido: espaço que circunda a superfície terrestre

Contextualizações: 1) De tarde, como estava sendo, esfriava um pouco, por pejo de vento - o que vem da Serra do Espinhaço - um vento com todas almas. Arrepio que fuxicava as folhagens ali, e ia, lá adiante longe, na baixada do rio, balançar esfiapado o pendão branco das canabravas.P.132; 2) quando o vento dava para trás, trazia as tristes fumaças. De noite, o morro se esclarecia, vermelho, asgrava em labaredas e brasas.p.133; 3) Saudades, dessas que respondem ao vento; saudade dos Gerais. O senhor vê: o remôo do vento nas palmas dos buritis todos, quando é ameaço de tempestade. Alguém esquece isso? O vento é verde. p. 132; 4) Vento que vem de toda parte. Dando no meu corpo, aquele ar me falou em gritos de liberdade.p.140; 5) Estes gerais enormes, em ventos, danando em raios, e fúria, o armar do trovão, as feias onças. O sertão tem medo de tudo.p.143; 6)Travessia perigosa, mas é a vida. Sertão que se alteia e se abaixa. Mas que as curvas dos campos estendem sempre para mais longe. Ali envelhece vento. E os brabos bichos, do fundo dele...p.250; 7-)Até sem ter aviso nenhum, eu me havia do Hermógenes. Pressentidos, todos os ventos eu farejava.p. 251

\begin{tabular}{|c|c|c|c|}
\hline \multirow{4}{*}{$\begin{array}{l}\text { NATUREZA } \\
\text { DOS } \\
\text { SEMAS } \\
\text { CONCEPTUAIS } \\
\text { FORMADORES }\end{array}$} & Classe de Noemas & Caracterização Semântico-Conceptual & Natureza \\
\hline & Conceptus & $\begin{array}{l}\text { Balanço nas palmas de buriti e no pendão } \\
\text { das canabravas que traz frio e anúncio das } \\
\text { tempestades }\end{array}$ & $\begin{array}{l}\text { Traços biofísicos } \\
\text { culturais }\end{array}$ \\
\hline & Metaconceptus & $\begin{array}{l}\text { Verde arrepio que fuxica as folhagens dos } \\
\text { Gerais }\end{array}$ & $\begin{array}{l}\text { Traços culturais } \\
\text { ideológicos }\end{array}$ \\
\hline & Metametaconceptus & $\begin{array}{l}\text { Danação de raios e fúria, com bichos } \\
\text { brabos e almas no seu fundo que asgra } \\
\text { morros e as curvas dos campos estendem } \\
\text { para mais longe. }\end{array}$ & $\begin{array}{l}\text { Traços culturais } \\
\text { modalizantes } \\
\text { intencionais }\end{array}$ \\
\hline
\end{tabular}

\begin{tabular}{|c|c|c|c|c|c|}
\hline \multicolumn{6}{|l|}{ SEMAS } \\
\hline $\begin{array}{l}\text { balanço que } \\
\text { vem de tarde }\end{array}$ & carrega almas & fuxica as folhagens & é verde & alteia o sertão & $\begin{array}{l}\text { ar que fala em gritos } \\
\text { de liberdade }\end{array}$ \\
\hline $\begin{array}{l}\text { que vem da } \\
\text { serra do } \\
\text { Espinhaço }\end{array}$ & traz saudade & balança esfiapado & & abaixa o sertão & \\
\hline \multirow[t]{4}{*}{$\begin{array}{l}\text { que vai para a } \\
\text { baixada do rio }\end{array}$} & $\begin{array}{l}\text { traz tristes } \\
\text { fumaças }\end{array}$ & $\begin{array}{l}\text { balança o pendão } \\
\text { branco das } \\
\text { canabravas }\end{array}$ & & $\begin{array}{l}\text { envelhece o } \\
\text { sertão }\end{array}$ & \\
\hline & $\begin{array}{l}\text { traz bichos } \\
\text { brabos }\end{array}$ & $\begin{array}{l}\text { remói as palmas de } \\
\text { buriti }\end{array}$ & & & \\
\hline & traz más notícias & $\begin{array}{l}\text { esclarece o morro } \\
\text { de vermelho }\end{array}$ & & & \\
\hline & $\begin{array}{l}\text { traz } \\
\text { pressentimentos }\end{array}$ & $\begin{array}{l}\text { dá para trás e } \\
\text { asgrava o morro } \\
\text { em alabaredas e } \\
\text { brasas }\end{array}$ & & & \\
\hline
\end{tabular}

Definição do vocábulo-termo VENTO: Balanço verde que vem de tarde, de toda parte, arrepia e envelhece o sertão trazendo maus pressentimentos e más notícias, com almas e bichos brabos dentro dele, que asgra morros e as curvas dos campos estende para mais longe.

Observações: Em Grande Sertão o vento assume características humanas e está sempre presente na vida de Riobaldo. De acordo com a herança culturalmente herdada, assume universalmente sua forma pelo assobio do homem. Esta proximidade explica-se pela leitura do vento, pelo sertanejo, para definir todos os momentos da sua vida cotidiana. Para o homem do campo, acostumado à terra, o vento é misterioso e mágico. Arroyo, p.201-202. Em Martins: Asgrar, forma não-dicionarizada, Faiscar, arder,//"[...] f. verbalizada (deformada) de áscua (= brasa viva, faísca)" ( N.L. de Castro). 
Ficha Etnoterminológica $n^{\circ} 9$

Vocábulo-termo: GERAIS

Ocorrências: 43

Significado no dicionário Aurélio: Campos do Planalto Central. Campos cobertos de erva ou grama. Campos extensos inaproveitáveis e desabitados. Estar em seus gerais: estar a seu gosto, em liberdade, contente, satisfeito

Contextualizações: 1)Sempre, no gerais, é à pobreza, à tristeza.p.10; 2) O Chapadão é em sobre longe, beira até Goiás, extrema. Os gerais desentendem de tempo. p.49; 3) Aquele povo estava sempre misturado, todo o mundo. Tudo era falado a todos, do comum: às mostras, às vistas. Diferente melhor, foi quando estivemos com Medeiro Vaz: o maior número lá era de pessoal dos gerais - gente mais calada em si e sozinha, moradores das grandes distâncias; 4) O pobre sozinho, sem um cavalo, fica no seu, permanece, feito numa crôa ou ilha, em sua beira de vereda. Homem a pé, esses Gerais comem.P 170; 5) Pelo que, do trecho, voltamos. Para mais poente do que lá, só uruburetamas. E o caminho nosso era retornar por essas gerais de Goiás - como lá alguns falam. O retornar para estes gerais de Minas Gerais. Para trás deixamos várzeas, cafundão, deixamos fechadas matas.p.244; 6) Mas, como jagunços, que se era, a gente rompeu adiante, com bons cavalos novos para retroco. Sobre os gerais planos de areia, cheios de nada. Sobre o pardo, nas areias que morreram, sem serras de quebra-vento.p.250; 7) Porque, nos gerais, a mesma raça de borboletas, que em outras partes é trivial regular - cá cresce, vira muito maior, e com mais brilho, se sabe; acho que é do seco do ar, do limpo, desta luz enorme.p.280.

\begin{tabular}{|l|l|l|l|}
\hline $\begin{array}{l}\text { NATUREZA } \\
\text { DOS } \\
\text { SEMAS } \\
\text { CONCEPTUAIS } \\
\text { FORMADORES }\end{array}$ & Classe de Noemas & Caracterização Semântico-Conceptual & Natureza \\
\cline { 2 - 4 } & Conceptus & $\begin{array}{l}\text { Planos de areia parda, sem serras ou mata } \\
\text { fechada, com ar seco, sol forte e habitantes } \\
\text { que moram sozinhos, a grandes distancias } \\
\text { um dos outros e são, por isso, calados. }\end{array}$ & Traços biofísicos \\
\cline { 2 - 5 } & Metaconceptus & $\begin{array}{l}\text { Onde as borboletas crescem muito mais e } \\
\text { são mais brilhantes que em outros lugares. }\end{array}$ & $\begin{array}{l}\text { Traços culturais } \\
\text { ideológicos }\end{array}$ \\
\cline { 2 - 5 } & Metametaconceptus & $\begin{array}{l}\text { Planos cheios do nada que comem o } \\
\text { homem a pé. }\end{array}$ & $\begin{array}{l}\text { Traços culturais } \\
\text { modalizantes } \\
\text { intencionais }\end{array}$ \\
\hline
\end{tabular}

\begin{tabular}{|c|c|c|c|c|c|c|}
\hline \multicolumn{7}{|l|}{ SEMAS } \\
\hline $\begin{array}{l}\text { região do } \\
\text { Planalto } \\
\text { Central do } \\
\text { Brasil }\end{array}$ & $\begin{array}{l}\text { tem } \\
\text { pobreza }\end{array}$ & $\begin{array}{l}\text { onde habitam } \\
\text { pessoas sozinhas }\end{array}$ & $\begin{array}{l}\text { com ar } \\
\text { seco }\end{array}$ & $\begin{array}{l}\text { que come } \\
\text { homem a pé }\end{array}$ & $\begin{array}{l}\text { sem mata } \\
\text { fechada }\end{array}$ & $\begin{array}{l}\text { com } \\
\text { arvorezinhas } \\
\text { tortas }\end{array}$ \\
\hline $\begin{array}{l}\text { paisagem } \\
\text { geográfica }\end{array}$ & tem tristeza & $\begin{array}{l}\text { onde habitam } \\
\text { pessoa caladas }\end{array}$ & $\begin{array}{l}\text { com ar } \\
\text { limpo }\end{array}$ & & $\begin{array}{l}\text { sem serras de } \\
\text { quebra-vento }\end{array}$ & $\begin{array}{l}\text { com } \\
\text { arvorezinhas } \\
\text { baixas }\end{array}$ \\
\hline Planalto & $\begin{array}{l}\text { não tem } \\
\text { nada }\end{array}$ & $\begin{array}{l}\text { onde habitam } \\
\text { pessoas distantes }\end{array}$ & $\begin{array}{l}\text { com luz } \\
\text { enorme }\end{array}$ & & $\begin{array}{l}\text { com planos de } \\
\text { areia }\end{array}$ & $\begin{array}{l}\text { com } \\
\text { arvorezinhas } \\
\text { enfezadas }\end{array}$ \\
\hline $\begin{array}{l}\text { serras mais } \\
\text { ou menos } \\
\text { tabulares }\end{array}$ & $\begin{array}{l}\text { tem } \\
\text { borboletas } \\
\text { maiores e } \\
\text { com mais } \\
\text { brilho }\end{array}$ & $\begin{array}{l}\text { onde homem sem } \\
\text { cavalo fica como } \\
\text { uma croa ou ilha }\end{array}$ & & & $\begin{array}{l}\text { com areias } \\
\text { pardas }\end{array}$ & $\begin{array}{l}\text { com capim } \\
\text { áspero }\end{array}$ \\
\hline
\end{tabular}

Definição do vocábulo-termo GERAIS: Chapadas e chapadões imensos, planos, de chão arenoso, sem serras, matas ou florestas e luz enorme, com moradores esparsos, solitários e calados, onde as borboletas crescem mais e com maior brilho,onde o homem sem cavalo fica ilhado e os gerais comem.

Observações: Rosa descreveu os gerais, em carta a Bizzarri: ... desde grande parte de Minas Gerais (Oeste e sobretudo Nordeste), aparecem os "campos gerais", ou "gerais" - paisagem geográfica que se estende, pelo Oeste da Bahia, e Goiás (onde a palavra vira feminina: as gerais), até ao Piauí e ao Maranhão. O que caracteriza esses GERAIS são as chapadas (planaltos, amplas elevações de terreno, chatas, às vezes serras mais ou menos tabulares) e os chapadões (grandes, imensas chapadas, às vezes séries de chapadas.. A vegetação é a do cerrado: arvorezinhas tortas, baixas, enfezadas (só persistem porque teem longuíssimas raízes verticais, pivotantes, que mergulham a incríveis profundidades). E o capim, ali, é áspero, de péssima qualidade, que, no reverdecer, no tempo- das - águas, crescem incrustados na areia, de partículas de sílica, como se fosse vidro moído..p.40 
Significado no dicionário Houaiss: Rubrica: religião, teologia. segundo a crença de diferentes povos antigos e modernos, espírito ou gênio do mal; anjo mau segundo a religião cristã, o anjo rebelde (Satanás) que foi expulso do céu e precipitado no abismo (inferno); espírito das trevas; cada um dos anjos rebeldes e malditos como Satanás.

Contextualizações:1) Bem, o diabo regula seu estado preto, nas criaturas, nas mulheres, nos homens. Até: nas crianças - eu digo. Pois não é ditado: "menino - trem do diabo"? E nos usos, nas plantas, nas águas, na terra, no vento.p.3. 2) O diabo vige dentro do homem, os crespos do homem - ou é o homem arruinado, ou o homem dos avessos. Solto, por si, cidadão, é que não tem diabo nenhum.p.3; 4) Que o que gasta, vai gastando o diabo de dentro da gente, aos pouquinhos, é o razoável sofrer.p.3; 4) depois quando o diabo pede se perfaz. p.19; 5) o diabo sai por toda parte lambendo o prato.p.24; 6) E sei que em cada virada de campo, e debaixo de sombra de cada árvore, está dia e noite um diabo, que não dá movimento, tomando conta.p.131;7) E o demo existe? Só se existe o estilo dele, solto, sem um ente próprio - feito remanchas n'água. A saúde da gente entra no perigo daquilo, feito num calor, num frio.p.222; 8) Quem entende a espécie do demo? Ele não fura: rascrava. Demorar comigo ele podia. E, o que não existe de se ver, tem força completa demais, em certas ocasiões.p.225.

\begin{tabular}{|l|l|l|l|}
\hline $\begin{array}{l}\text { NATUREZA } \\
\text { DOS } \\
\text { SEMAS } \\
\text { CONCEPTUAIS } \\
\text { FORMADORES }\end{array}$ & Classe de Noemas & Caracterização Semântico-Conceptual & Natureza \\
\cline { 2 - 4 } & Conceptus & $\begin{array}{l}\text { Ente do mal ou rebelde que foi expulso do } \\
\text { céu. }\end{array}$ & Traços psicossociais \\
\cline { 2 - 5 } & Metaconceptus & Homem dos avessos, arruinado. & Traços culturais ideológicos \\
\cline { 2 - 5 } & Metametaconceptus & $\begin{array}{l}\text { Remanchas n`água, sem um ente próprio, } \\
\text { que não existe de se ver e tem força } \\
\text { completa demais em certas ocasiões. }\end{array}$ & $\begin{array}{l}\text { Traços culturais } \\
\text { modalizantes intencionais }\end{array}$ \\
\hline
\end{tabular}

\begin{tabular}{|c|c|c|c|c|c|}
\hline \multicolumn{6}{|l|}{ SEMAS } \\
\hline \multirow[t]{5}{*}{ ente do mal } & $\begin{array}{l}\text { homem } \\
\text { arruinado }\end{array}$ & $\begin{array}{l}\text { vige dentro do } \\
\text { homem }\end{array}$ & $\begin{array}{l}\text { não tem um ente } \\
\text { próprio }\end{array}$ & $\begin{array}{l}\text { pede e se } \\
\text { perfaz }\end{array}$ & $\begin{array}{l}\text { encontrado em cada virada } \\
\text { de campo }\end{array}$ \\
\hline & $\begin{array}{l}\text { homem dos } \\
\text { avessos }\end{array}$ & $\begin{array}{l}\text { não existe } \\
\text { solto, por si, } \\
\text { cidadão }\end{array}$ & tem estilo solto & toma conta & $\begin{array}{l}\text { encontrado debaixo da } \\
\text { sombra da árvore }\end{array}$ \\
\hline & $\begin{array}{l}\text { de dentro da } \\
\text { gente }\end{array}$ & & $\begin{array}{l}\text { não existe de se } \\
\text { ver }\end{array}$ & não fura & $\begin{array}{l}\text { encontrado de dia e de } \\
\text { noite }\end{array}$ \\
\hline & & & $\begin{array}{l}\text { tem força } \\
\text { completa demais, } \\
\text { em certas } \\
\text { ocasiões }\end{array}$ & $\begin{array}{l}\text { regula seu } \\
\text { estado preto } \\
\text { nas criaturas, } \\
\text { usos, plantas, } \\
\text { águas, terra, } \\
\text { vento }\end{array}$ & $\begin{array}{l}\text { encontrado nas remanchas } \\
\text { da água }\end{array}$ \\
\hline & & & $\begin{array}{l}\text { não dá } \\
\text { movimento }\end{array}$ & rascrava & \\
\hline
\end{tabular}

Definição do vocábulo-termo DIABO: Sem um ente próprio, não existe solto por si só, é dos avessos do homem arruinado, encontrado em cada virada de campo, sombra de árvore, remanchas da água, terra e vento, de dia e de noite, rascrava e tem força completa demais em certas ocasiões.

Observações: De acordo com Arroyo, em várias regiões do Brasil, inclusive no Centro do país, é herança portuguesa a substituição do nome do diabo por outros apelidos: " não se deve nunca chamá-lo pelo seu verdadeiro nome, para que não ouça e não venha" Arroyo, p.144. Sobre essa crença, o uso de nomes de rebuço, Riobaldo indaga: "Então? Que-Diga? Doideira. A fantasiação. E, o respeito de dar a ele assim esses nomes de rebuço, é que é mesmo um querer invocar que ele forme forma, com as presenças!” p.2; e ainda: Do demo? Não gloso. Senhor pergunte aos moradores. Em falso receio desfalam no nome dele - dizem só: Que-Diga. Vote! Não... Quem muito se evita, se convive. p. 2. Em Martins encontramos o significado de rascravar: Não dicionarizado. Penetrar fundamente.//Combinação de rascar, 'lascar', 'desbastar', 'ferir', com cravar, 'fazer penetrar à força' (N.L. de Castro). 
Significado no dicionário Moraes Silva: Caminho estreito e não estrada real. Sentido figurado; O modo de vida, os passos, methodo, ordem; Houaiss:Regionalismo: Centro-Oeste do Brasil. caminho estreito, senda, sendeiro. Caminho secundário pelo qual se chega mais rapidamente a um lugar; atalho.Derivação: sentido figurado. orientação de uma vida, de uma ação; rumo, direção, caminho.Campo ou terreno brejoso, situado em encosta, esp. perto de cabeceira de rio, geralmente coberto com vegetação rasteira graminosa. Regionalismo: Brasil. local úmido e fértil para agricultura. Regionalismo: Minas Gerais, Centro-Oeste do Brasil. na região dos cerrados, curso de água orlado por buritizais.

Contextualizações: 1) Conforme contei ao senhor, quando Otacília comecei a conhecer, nas serras dos gerais, Buritis Altos, nascente de vereda, Fazenda Santa Catarina.p. 85 ;2) Me deu saudade de algum buritizal, na ida duma vereda em capim tem-te que verde, termo da chapada.p132; 3) Aquilo nem era só mata, era até florestas! Montamos direito, no Olho d'Água-das-Outras, andamos, e demos com a primeira vereda - dividindo as chapadas -: o flaflo de vento agarrado nos buritis, franzido no gradeai de suas folhas altas; e, sassafrazal - como o da alfazema, um cheiro que refresca; e aguadas que molham sempre..p.140; 4) E como cada vereda, quando beirávamos, por seu resfriado, acenava para a gente um fino sossego sem notícia - todo buritizal e florestal: ramagem e amar em água.p.140; 5) E lá era que o senhor podia estudar o juízo dos bandos de papagaios. O quanto em toda vereda em que se baixava, a gente saudava o buritizal e se bebia estável.p.170; 6) que nem, dos brejos dos Gerais, sai uma vereda para o nascente e outra para o poente, riachinhos que se apartam de vez, mas correndo, claramente, na sombra de seus buritizais...p.251;7) A vereda recruza, reparte o plaino, de esguelha, da cabeceira-do-mato da Mata- Pequena para a casa-de-fazenda, e é alegrante verde, mas em curtas curvas, como no sucinto caminhar qualquer cobra faz. E tudo. O resto, céu e campo.p. 252 .

\begin{tabular}{|l|l|l|l|}
\hline $\begin{array}{l}\text { NATUREZA } \\
\text { DOS }\end{array} \begin{array}{l}\text { SEMAS } \\
\text { CONCEPTUAIS } \\
\text { FORMADORES }\end{array}$ & Classe de Noemas & Caracterização Semântico-Conceptual & Natureza \\
\cline { 2 - 5 } & Conceptus & $\begin{array}{l}\text { Lugar entre as chapadas, no interior dos } \\
\text { Gerais, com vegetação verde, nascente } \\
\text { com agua potável e aves, onde se } \\
\text { encontram fazendas e habitações. }\end{array}$ & Traços biofísicos \\
\cline { 2 - 5 } & Metaconceptus & $\begin{array}{l}\text { Local de sombra verde de buritis onde se } \\
\text { bebe estável e se pode estudar o juízo dos } \\
\text { papagaios. }\end{array}$ & Traços culturais ideológicos \\
\cline { 2 - 5 } & Metametaconceptus & "Oásis" & $\begin{array}{l}\text { Traços culturais } \\
\text { modalizantes intencionais }\end{array}$ \\
\hline
\end{tabular}

\begin{tabular}{|c|c|c|c|c|c|}
\hline \multicolumn{6}{|l|}{ SEMAS } \\
\hline $\begin{array}{l}\text { paisagem } \\
\text { geográfica do } \\
\text { Centro-Oeste } \\
\text { do Brasil }\end{array}$ & $\begin{array}{l}\text { divide as } \\
\text { chapadas }\end{array}$ & $\begin{array}{l}\text { com rios } \\
\text { pequenos }\end{array}$ & $\begin{array}{l}\text { com cheiro que } \\
\text { refresca }\end{array}$ & $\begin{array}{l}\text { local de } \\
\text { descanso }\end{array}$ & dá sombra \\
\hline nos Gerais & $\begin{array}{l}\text { recruza e } \\
\text { reparte o plaino } \\
\text { de esguelha }\end{array}$ & $\begin{array}{l}\text { com nascentes } \\
\text { nas serras }\end{array}$ & com papagaios & $\begin{array}{l}\text { local onde se } \\
\text { encontram } \\
\text { fazendas }\end{array}$ & dá saudade \\
\hline \multirow[t]{4}{*}{$\begin{array}{l}\text { no termo da } \\
\text { chapada }\end{array}$} & $\begin{array}{l}\text { vai da } \\
\text { cabeceira da } \\
\text { mata para a } \\
\text { casa da fazenda }\end{array}$ & com resfriado & com água potável & & \\
\hline & & com capim verde & $\begin{array}{l}\text { com alegrante } \\
\text { verde }\end{array}$ & & \\
\hline & & com buritizal & & & \\
\hline & & $\begin{array}{l}\text { com matas e } \\
\text { florestas }\end{array}$ & & & \\
\hline
\end{tabular}

Definição do vocábulo-termo VEREDA: Local de descanso com vegetação e cheiro que refresca, com animais, pássaros e água potável, ornado pelos buritis de alegrante verde, clima ameno, encontrado em meio aos campos gerais desérticos é, para o sertanejo, um "oásis" no meio do sertão.

Observações: "Nas veredas, há sempre o buriti. De longe, a gente avista os buritis, e já sabe: lá se encontra água. A vereda é um oásis". Assim definida por Rosa em sua correspondência com Bizarri, p.16 desta Dissertação. 
Significado no dicionário Aurélio: 1. [Do tupi mburít.] S. m. Bras. , PA a SP. 1. Palmeira (Mauritia vinifera) dotada de fruto amarelo, do qual se extrai óleo e broto terminal comestível, e de espique se fabrica o vinho de buriti; 2 . O fruto dessa palmeira.

Contextualizações: 1) Dum geralista roto, ganhamos farinha-de-buriti, sempre ajudava. p.23; 2) Cobrimos o corpo com palmas de buriti novo, cortadas molhadas. p.35; 3) [...] e trazia para mim caixetas de doce de buriti [...] p.51; 4)Desceu o Rio Paracatu numa balsa de buriti. p.39; 5)Me deu saudade de algum buritizal, na ida duma vereda em capim tem-te que verde, termo da chapada. Saudades, dessas que respondem ao vento; saudade dos Gerais. O senhor vê: o remôo do vento nas palmas dos buritis todos, quando é ameaço de tempestade. Alguém esquece isso? p.132; [...] 6) a gente saudava o buritizal e se bebia estável p.170; 7) O senhor estude: o buriti é das margens, ele cai seus cocos na vereda - as águas levam - em beiras, o coquinho as águas mesmas replantam; dai o buritizal, de um lado e do outro se alinhando, acompanhando, que nem que por um cálculo p.172; [... 8) ou uma mulherzinha fiando a estriga na roca ou tecendo em seu tear de pau, na porta de uma choça, de buriti toda. p.175; [...] 9) amarelos de tanto comer só polpa de buriti, e fio que estavam bêbados, de beber tanta saeta.p.176; 10) [...] que nem, dos brejos dos Gerais, sai uma vereda para o nascente e outra para o poente, riachinhos que se apartam de vez, mas correndo, claramente, na sombra de seus buritizais...p.251; [...]Eu tinha tanto friúme, assim mesmo me requeimava forte sede. Desci, de retorno, para a beira dos buritis, aonde o pano d'água. A claridadezinha das estrelas indicava a raso a lisura daquilo. Ali era bebedouro de veados e onças. Curvei, bebi, bebi. E a água até nem não estava de frio geral: não apalpei nela a mornidão que devia-de, nos casos de frio real o tempo estar fazendo.p.194

\begin{tabular}{|c|c|c|c|}
\hline \multirow{4}{*}{$\begin{array}{l}\text { NATUREZA } \\
\text { DOS } \\
\text { SEMAS } \\
\text { CONCEPTUAIS } \\
\text { FORMADORES }\end{array}$} & Classe de Noemas & Caracterização Semântico-Conceptual & Natureza \\
\hline & Conceptus & $\begin{array}{l}\text { Palmeira que cresce às margens da água doce e que } \\
\text { produz cocos que são levados pela água, } \\
\text { reproduzindo-se dos dois lados do rio. Produz pão, } \\
\text { doces, bebida, cobertas, balsa, choças e telhados } \\
\text { para cobri-las. }\end{array}$ & $\begin{array}{l}\text { Traços biofísicos e } \\
\text { culturais }\end{array}$ \\
\hline & Metaconceptus & $\begin{array}{l}\text { Acena um fino sossego, segurança e aconchego com } \\
\text { água para saciar a sede, refrescar-se e descansar, } \\
\text { refletir e aprender. Suas palmas fazem sombra, } \\
\text { trazem saudade dos Gerais e notícia de tempestade }\end{array}$ & $\begin{array}{l}\text { Traços culturais } \\
\text { ideológicos }\end{array}$ \\
\hline & Metametaconceptus & A árvore da vida, a palmeira de Deus. & $\begin{array}{l}\text { Traços culturais } \\
\text { modalizantes } \\
\text { intencionais }\end{array}$ \\
\hline
\end{tabular}

\begin{tabular}{|c|c|c|c|c|c|}
\hline \multicolumn{5}{|l|}{ SEMAS } & \\
\hline vegetal & $\begin{array}{l}\text { para cobrir o } \\
\text { corpo dos } \\
\text { viajantes }\end{array}$ & $\begin{array}{l}\text { dele se faz um } \\
\text { doce (saieta) }\end{array}$ & dos gerais & dá saudade & \\
\hline palmeira & $\begin{array}{l}\text { para fazer } \\
\text { telhados } \\
\end{array}$ & dele se fazem balas & nas chapadas & $\begin{array}{l}\text { dá um sossego } \\
\text { agarrado }\end{array}$ & \\
\hline produz cocos & $\begin{array}{l}\text { para cobrir } \\
\text { choça }\end{array}$ & $\begin{array}{l}\text { dele se faz pão } \\
\text { doce }\end{array}$ & viceja nas veredas & $\begin{array}{l}\text { leva ao lugar de } \\
\text { descanso }\end{array}$ & \\
\hline com palmas & para fazer balsa & $\begin{array}{l}\text { dele se produz } \\
\text { cachaça (Saeta) }\end{array}$ & às margens dos riachos & & \\
\hline \multirow[t]{2}{*}{ dá sombra } & & dele se faz farinha & $\begin{array}{l}\text { seus cocos caem às } \\
\text { margens dos riachos }\end{array}$ & & \\
\hline & & $\begin{array}{l}\text { da sua polpa se faz } \\
\text { alimento }\end{array}$ & & & \\
\hline
\end{tabular}

Definição do vocábulo-termo BURITI: Palmeira de Deus, árvore sagrada, integra a vida cotidiana do sertanejo e a paisagem do sertão,dá saudade e um sossego agarrado, viceja nas veredas e se alinha que nem por um cálculo às margens das águas que levam seus cocos.

Observações: Martius e Spix registraram que o buriti fornece aos "habitantes fios e fibras resistentes, retiradas da epiderme das folhas; com estas, dá coberta para palhoças; fazem-se gradeados e ripas, com a parte periférica de seu caule; remos, com a haste de suas folhas; uma bebida muito agradável, semelhante a água de bétula e suscetível de fermentação alcoólica, com a seiva contida no caule;e um saboroso petisco é preparado com a polpa do fruto, misturando com açúcar, que, com o nome de saieta, é doce apreciado e artigo de comércio do sertão de minas com a costa. Todas estas utilidades tornaram quase sagrada para os sertanejos a preciosa árvore e, nalgumas regiões, como por exemplo, em São Romão, é costume dar-se em dote à filha também um certo número de buritis" p.168. Teodoro Sampaio registrou em 1877, "cresce copado e vigoroso o buriti, orlando de verde os brejais" (vide p.28 desta Dissertação). 
Significado no dicionário Houaiss: área marítima, fluvial ou lacustre, abrigada, junto ao litoral ou à margem, que dispõe de instalações para embarque e desembarque de passageiros e mercadorias, e armazenamento destas últimas

Contextualizações: 1) No porto do Rio-de-Janeiro nosso, o senhor viu. Hoje, lá é o porto do seo Josozinho, o negociante. Porto, lá como quem diz, porque outro nome não há. Assim sendo, verdade, que se chama, no sertão: é uma beira de barranco, com uma venda, uma casa, um curral e um paiol de depósito. Cereais. p.44; 2) Somente ficados com um cavalinho só, Alaripe e eu, Diadorim e Jesualdo, andamos beira-rio, no vagarosamente. A gente esperava o que acontecesse. Ali mais adiante, era um porto-de-lenha. p.139; 3) À Januária eu ia, mais Diadorim, ver o vapor chegar com apito, a gente esperando toda no porto. Ali, o tempo, a rapaziada suava, cuidando nos alambiques, como perfeito se faz. p.154;

\begin{tabular}{|c|c|c|c|}
\hline \multirow{4}{*}{$\begin{array}{l}\text { NATUREZA } \\
\text { DOS } \\
\text { SEMAS } \\
\text { CONCEPTUAIS } \\
\text { FORMADORES }\end{array}$} & Classe de Noemas & Caracterização Semântico-Conceptual & Natureza \\
\hline & Conceptus & $\begin{array}{l}\text { Beira de barranco com venda, casa, curral, } \\
\text { paiol e alambiques onde chegam os } \\
\text { vapores. }\end{array}$ & $\begin{array}{l}\text { Traços físicos } \\
\text { culturais }\end{array}$ \\
\hline & Metaconceptus & $\begin{array}{l}\text { Beira de rio onde as pessoas se reúnem } \\
\text { aguardando o apito que anuncia a chegada } \\
\text { do vapor. }\end{array}$ & $\begin{array}{l}\text { Traços culturais } \\
\text { ideológicos }\end{array}$ \\
\hline & Metametaconceptus & $\begin{array}{l}\text { Beira de barranco onde as pessoas se } \\
\text { reúnem, andam no vagarosamente e } \\
\text { esperam para ver o que acontece } \\
\text { enquanto antes do vapor chegar. }\end{array}$ & $\begin{array}{l}\text { Traços culturais } \\
\text { modalizantes } \\
\text { intencionais }\end{array}$ \\
\hline
\end{tabular}

\begin{tabular}{|c|c|c|c|c|c|}
\hline SEMAS & & & & & \\
\hline $\begin{array}{l}\text { lugar onde } \\
\text { chegam }\end{array}$ & $\begin{array}{l}\text { onde se fazem } \\
\text { negócios }\end{array}$ & $\begin{array}{l}\text { na beira de } \\
\text { barranco }\end{array}$ & com venda & para passear & no vagarosamente \\
\hline & & na beira de rio & com casa & para esperar & \\
\hline & & & com curral & para reunir & \\
\hline & & & $\begin{array}{l}\text { com paiol de } \\
\text { depósito }\end{array}$ & & \\
\hline & & & com alambique & & \\
\hline
\end{tabular}

Definição do vocábulo-termo PORTO: Beira de barranco onde as pessoas se reúnem e andam, no vagarosamente, se distraindo e esperando a chegada do vapor com apito.

Observações: A exemplo de venda, o porto é o lugar social de interação e momentos de distração do sertanejo. 
Significado no dicionário Houaiss: Relativo a Urucuia, MG ou o que é seu natural ou habitante.

Contextualizações: 1) O urucuiano, deles, que o Salústio se chamava. O que tinha os olhos miudinhos em cara redonda, boca mole e sete fios de barba compridos no queixo. Arreliado falei: - "Que que é? Tu amigou comigo?! Tatu - tua casa..." - para ele. Semi-sério ele se riu. Comparsa urucuiano dos olhos verdes, homem muito feioso. Ainda nada não disse, coçou a barriga com as costas dobradas da mão - gesto de urucuiano.p.158; 2) Queriam conversa comigo em só, apartada. Eu apreciasse aqueles homens. A valentia deles estava por dentro de muita seriedade. Urucuiano conversa com o peixe para vir no anzol - o povo diz. As lérias. Como contam também que nos Gerais goianos se salga o de-comer com suor de cavalo... Sei lá, sei? Um lugar conhece outro é por calúnias e falsos levantados; as pessoas também, nesta vida. Mas aqueles cinco me condiziam. Admirei de ver que eles todos ainda estavam a pé, mas com dobros e bissacos nas costas, feito prontos para pedestre viagem. Sisudez deles ainda semelhava maior.p.228

\begin{tabular}{|l|l|l|l|}
\hline $\begin{array}{l}\text { NATUREZA } \\
\text { DOS } \\
\text { SEMAS } \\
\text { CONCEPTUAIS } \\
\text { FORMADORES }\end{array}$ & Classe de Noemas & Caracterização Semântico-Conceptual & Natureza \\
\cline { 2 - 4 } & Conceptus & $\begin{array}{l}\text { Homem oriundo da região do Urucuia } \\
\text { (MG). }\end{array}$ & Traços biofísicos \\
\cline { 2 - 4 } & Metaconceptus & Homem feioso, sisudo, de olhos verdes. & Traços culturais ideológicos \\
\cline { 2 - 4 } & Metametaconceptus & $\begin{array}{l}\text { Homem que se ri semi-sério, de conversa } \\
\text { em só apartada e de valentia por dentro } \\
\text { de muita seriedade. }\end{array}$ & $\begin{array}{l}\text { Traços culturais modalizantes } \\
\text { intencionais }\end{array}$ \\
\hline
\end{tabular}

\begin{tabular}{|c|c|c|c|c|c|}
\hline \multicolumn{6}{|l|}{ SEMAS } \\
\hline \multirow[t]{4}{*}{$\begin{array}{l}\text { homem natural } \\
\text { ou habitante do } \\
\text { Urucuia }\end{array}$} & ri semi-sério & feioso & $\begin{array}{l}\text { de conversa em } \\
\text { só e apartada }\end{array}$ & de se apreciar & $\begin{array}{l}\text { que coça a } \\
\text { barriga com as } \\
\text { costas dobradas } \\
\text { da mão }\end{array}$ \\
\hline & & valente & & de se condizer & \\
\hline & & sério & & de se admirar & \\
\hline & & sisudo & & & \\
\hline
\end{tabular}

Definição do vocábulo-termo URUCUIANO: Homem da região do Urucuia, que coça a barriga com as costas dobradas da mão, que se ri semi-sério, de conversa em só apartada e digno de admiração,

Observações: Arroyo destaca que é conceito popular serem os urucuianos povo sagaz, silencioso e de muita sabedoria. A frase que melhor expressa o conceito popular sobre esse povo "Urucuiano conversa com o peixe para vir no anzol" foi dita por Riobaldo como lembrança de conhecimento herdado sobre os urucuianos. 
Significado no dicionário Houaiss: Regionalismo: Brasil. Estabelecimento humilde aberto por negros egressos de escravidão; 3.1 Derivação: por extensão de sentido. bar, botequim; pé-sujo 4. Regionalismo: Brasil. pequena mercearia ou bar em que funciona também uma pequena mercearia.

Contextualizações: 1) ia desempenhando seu negócio dele no sertão - que era o de trazer e vender de tudo para os fazendeiros: arados, enxadas, debulhadora, facão de aço, ferramentas rógers e roscofes, latas de formicida, arsênico e creolinas; até papa-vento, desses moinhos-de-vento de sungar água, com torre, ele tomava empreitada de armar. p.30/31; 2) A não ser a Rosa'uarda - moça feita, mais velha do que eu, filha de negociante forte, seo Assis Wababa, dono da venda O Primeiro Barateiro da Primavera de São José - ela era estranja, turca, eles todos turcos, armazém grande, casa grande, seo Assis Wababa de tudo comerciava. Tanto sendo bizarro atencioso, e muito ladino, ele me agradava, dizia que meu padrinho Selorico Mendes era um freguesão, diversas vezes me convidou para almoçar em mesa. O que apreciei... Assim mesmo afirmo que a Rosa'uarda gostou de mim, me ensinou as primeiras bandalheiras, e as completas, que juntos fizemos, no fundo do quintal, num esconso, fiz com muito anseio e deleite 51; 3) A quase meio-rumo de norte e nascente, a quatro léguas de demorado andamento, tinha uma venda de roça, no começo do cerradão. Vendiam licor de banana e de pequi, muito forte, geleia de mocotó, fumo bom, marmelada, toucinho.p.134.

\begin{tabular}{|c|c|c|c|}
\hline \multirow{4}{*}{$\begin{array}{l}\text { NATUREZA } \\
\text { DOS } \\
\text { SEMAS } \\
\text { CONCEPTUAIS } \\
\text { FORMADORES }\end{array}$} & Classe de Noemas & Caracterização Semântico-Conceptual & Natureza \\
\hline & Conceptus & $\begin{array}{l}\text { Negócio de trazer e vender de tudo para os } \\
\text { fazendeiros do sertão. }\end{array}$ & $\begin{array}{l}\text { Traços físicos } \\
\text { culturais }\end{array}$ \\
\hline & Metaconceptus & $\begin{array}{l}\text { Armazém de roça, no começo de cerradão, } \\
\text { que vende grande variedade de produtos para } \\
\text { o sertanejo. }\end{array}$ & $\begin{array}{l}\text { Traços culturais } \\
\text { ideológicos }\end{array}$ \\
\hline & Metametaconceptus & $\begin{array}{l}\text { Ponto de encontro frequentado pelas pessoas } \\
\text { que vendem e as pessoas que compram grande } \\
\text { variedade de produtos e que aí contam casos } \\
\text { e estórias passando a se conhecer melhor. }\end{array}$ & $\begin{array}{l}\text { Traços culturais } \\
\text { modalizantes } \\
\text { intencionais }\end{array}$ \\
\hline
\end{tabular}

\begin{tabular}{|c|c|c|c|c|c|}
\hline \multicolumn{6}{|l|}{ SEMAS } \\
\hline $\begin{array}{l}\text { estabelecimento } \\
\text { comercial }\end{array}$ & com casa & $\begin{array}{l}\text { para trazer } \\
\text { mercadorias } \\
\text { diversas } \\
\end{array}$ & $\begin{array}{l}\text { para os } \\
\text { fazendeiros }\end{array}$ & $\begin{array}{l}\text { no começo do } \\
\text { cerradão }\end{array}$ & $\begin{array}{l}\text { onde as } \\
\text { pessoas se } \\
\text { encontram }\end{array}$ \\
\hline loja & com quintal & $\begin{array}{l}\text { para vender } \\
\text { mercadorias } \\
\text { diversas }\end{array}$ & $\begin{array}{l}\text { para os } \\
\text { sertanejos }\end{array}$ & no sertão & $\begin{array}{l}\text { onde as } \\
\text { pessoas } \\
\text { conversam }\end{array}$ \\
\hline armazém & & $\begin{array}{l}\text { para } \\
\text { comercializar } \\
\text { produtos } \\
\text { variados } \\
\end{array}$ & & na roça & $\begin{array}{l}\text { onde se } \\
\text { contam } \\
\text { estórias }\end{array}$ \\
\hline negócio & & & & & \\
\hline
\end{tabular}

Definição do vocábulo-termo VENDA: Ponto de encontro entre as pessoas que vendem e as pessoas que compram produtos, mas também onde se conversa e onde são contados casos pelos viajantes que por lá passam.

Observações: Walnice Nogueira Galvão assim se refere à venda do pai de Rosa, que o acolheu nas escutas das estórias que contavam os frequentadores e viajantes (vaqueiros, fazendeiros, mascates, garimpeiros, caçadores) que por lá passavam: "A venda: esse misto de foco de sociabilidade masculina, central de informações, e banco de dados da história oral" CLB, p.158. Rosa por sua vez assim situou Cordisburgo: "Porta de entrada para o sertão mais escuro e ocultado demais" 
Significado no dicionário: Houaiss: quantidade ou medida que equivale duas vezes a uma outra; duplo 2 Uso: hiperbólico.quantidade bastante maior que outra 3 m.q. duplicação ('repetição') $\mathbf{4}$ peso que se põe sobre a carga de um animal para se obter equilíbrio 5 Regionalismo: Sul do Brasil. volume de pequeno porte que se acrescenta à carga dos tropeiros.

Contextualizações: 1) Mire veja o que a gente é: mal dali a um átimo, eu selando meu cavalo e arrumando meus dobros, e já me muito entristecia. Diadorim me espreitava de longe, afetando a espécie duma vagueza. No me despedir, tive precisão de dizer a ele, baixinho: - "Por teu pai vou, amigo, mano-oh-mano. Vingar Joca Ramiro..." A fraqueza minha, adulatória. Mas ele respondeu: - "Viagem boa, Riobaldo. E boa-sorte..." Despedir dá febre. p.28; 2) E tem as pequenas coisas que aperreiam: enquanto estava com meu animal, eu tinha a capoteira, a bolsa da sela, os alforjes; podia guardar meus trecos. De noite, dependurava a sela num galho de árvore, botava por debaixo dela o dobro com as roupas, dormia ali perto, em paz.p.76; 3) Carregar os trens não podia - chegava o peso das armas, e das balas e cartuchame. Perguntei a um, onde era que tudo se depositava. - "Eh, bereu... Bota em algum lugar... Joga fora... Oxe, tu carrega ouro nesses dobros?...”p.76; 4) Mas aqueles cinco me condiziam. Admirei de ver que eles todos ainda estavam a pé, mas com dobros e bissacos nas costas, feito prontos para pedestre viagem. p. 228

\begin{tabular}{|l|l|l|l|}
\hline $\begin{array}{l}\text { NATUREZA } \\
\text { DOS }\end{array} \begin{array}{l}\text { SEMAS } \\
\text { CONCEPTUAIS } \\
\text { FORMADORES }\end{array}$ & Classe de Noemas & Caracterização Semântico-Conceptual & Natureza \\
\cline { 2 - 4 } & Conceptus & $\begin{array}{l}\text { Saco para carregar objetos de uso pessoal } \\
\text { durante as viagens dos vaqueiros }\end{array}$ & Traços físico culturais \\
\cline { 2 - 4 } & Metaconceptus & $\begin{array}{l}\text { Saco com objetos de uso pessoal que o } \\
\text { vaqueiro mantém perto de si durante suas } \\
\text { viagens }\end{array}$ & $\begin{array}{l}\text { Traços culturais } \\
\text { ideológicos }\end{array}$ \\
\cline { 2 - 4 } & Metametaconceptus & $\begin{array}{l}\text { Pequeno volume com os objetos pessoais } \\
\text { arranjados antes da despedida do vaqueiro } \\
\text { para uma viagem }\end{array}$ & $\begin{array}{l}\text { Traços culturais } \\
\text { modalizantes intencionais }\end{array}$ \\
\hline
\end{tabular}

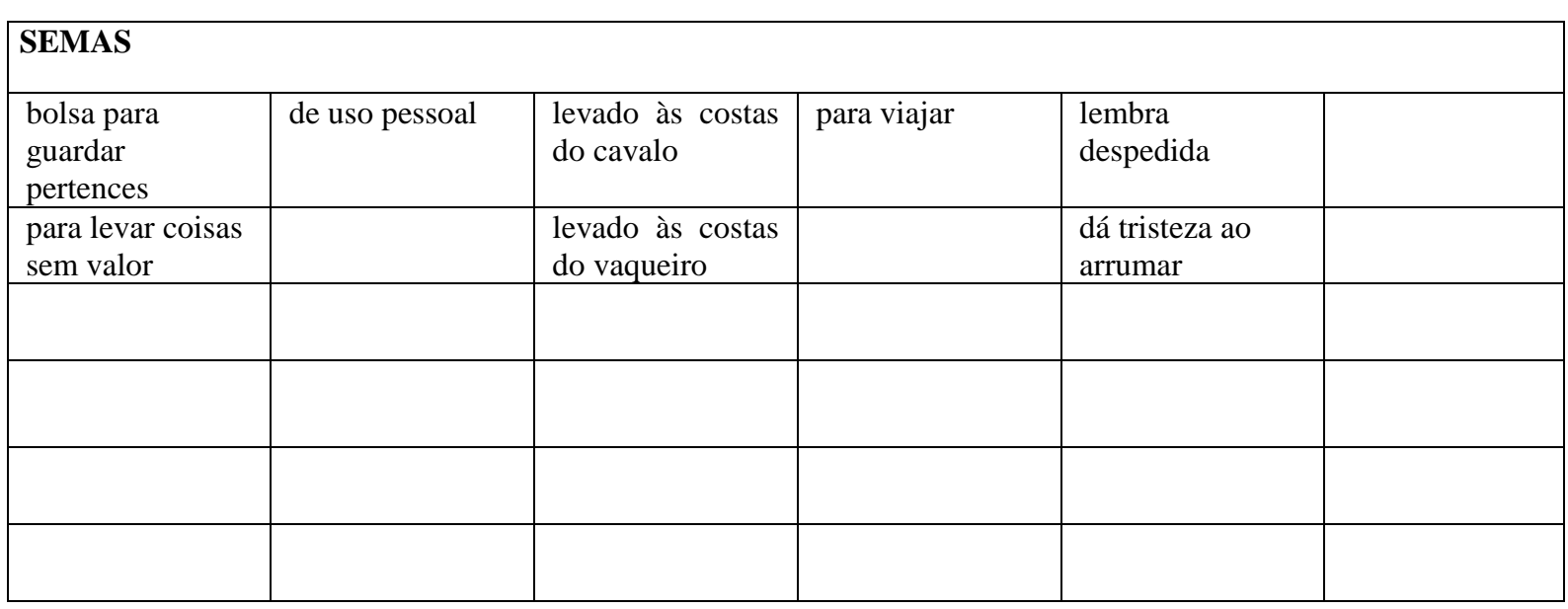

Definição do vocábulo-termo DOBRO(S): Pequeno volume em que o vaqueiro carrega objetos de uso pessoal, nas costas ou no lombo do cavalo, e que mantém todo o tempo perto de si.

Observações: Na correspondência com Edoardo Bizzarri, Rosa explicou: "é o saco ou trouxa em que os vaqueiros trazem suas roupas e objetos de uso pessoal quando viajam"p.62 
Significado no dicionário Houaiss Rubrica: culinária. Regionalismo:Brasil. Papa de farinha de mandioca preparada com mel, açúcar ou rapadura, a que se acrescenta, por vezes, leite ou cachaça e que tb. se dilui com água e sumo de limão, para servir como refresco. Café quente engrossado com farinha de mandioca. Uso: informal. qualquer refresco (bebida).

Contextualizações: 1) A tanto, mesmo sem fome, providenciei para mim uma jacuba, no come-calado. p.27; 2)As mantas de carne-ceará. Ao tanto que a carne-de-sol não faltasse, mesmo amiúde ainda saíam alguns e retornavam tocando uma rês, que repartiam. Muitos misturavam a jacuba pingando no coité um dedo de aguardente, eu nunca tinha avistado ninguém provar jacuba assim feita. Os usares! p. 76; 3) Agarrei minha mochila, comi fria a minha jacuba. p.90; 4) Essa gente estava tão devolvida de tudo, que eu não pude adivinhar a honestidade deles. O sertão nunca dá notícia. Eles serviram à gente farta jacuba. p.139; 5) Por mesmo que naquele dia eu estava de jejum quebrado só com uma jacuba. Nem quis pitar. p.253.

\begin{tabular}{|l|l|l|l|}
\hline $\begin{array}{l}\text { NATUREZA } \\
\text { DOS } \\
\text { SEMAS } \\
\text { CONCEPTUAIS } \\
\text { FORMADORES }\end{array}$ & Classe de Noemas & Caracterização Semântico-Conceptual & Natureza \\
\cline { 2 - 4 } & Conceptus & $\begin{array}{l}\text { Alimento ou bebida comum no cotidiano do } \\
\text { sertanejo }\end{array}$ & Traços biofísicos \\
\cline { 2 - 4 } & Metaconceptus & $\begin{array}{l}\text { Um dos pratos consumidos pelo sertanejo em } \\
\text { seus momentos de reunião. }\end{array}$ & $\begin{array}{l}\text { Traços culturais } \\
\text { ideológicos }\end{array}$ \\
\cline { 2 - 4 } & Metametaconceptus & $\begin{array}{l}\text { Prato oferecido entre os sertanejos } \\
\text { em sinal de amizade }\end{array}$ & $\begin{array}{l}\text { Traços culturais } \\
\text { modalizantes intencionais }\end{array}$ \\
\hline
\end{tabular}

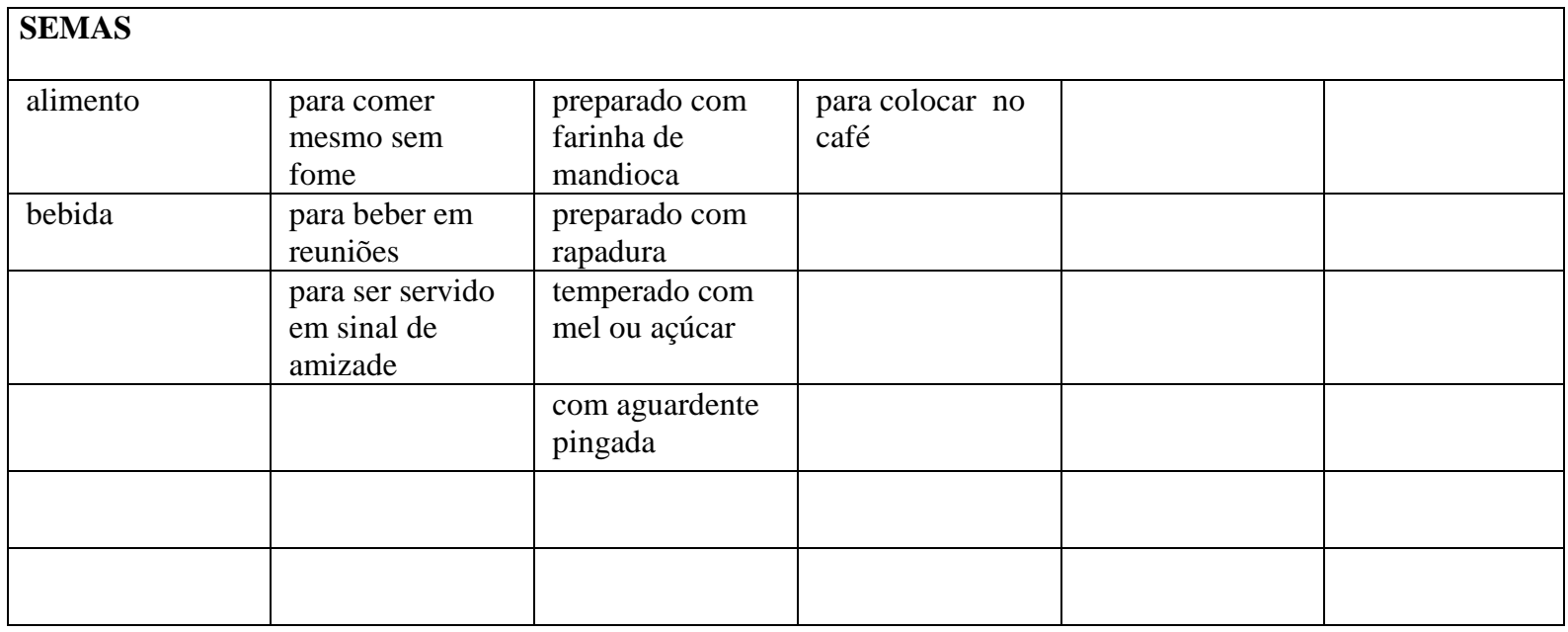

Definição do vocábulo-termo JACUBA: Alimento ou bebida comum entre os sertanejos que se come mesmo sem fome e que é servido em reuniões e em sinal de amizade. 
Significado no dicionário Houaiss: Relvado nos pastos, perto de cabeceiras, onde há umidade. Region: Bahia, Minas Gerais. Camada de terra sobre lajedos.

Contextualizações: Não, o caminho era da banda contrária.Tínhamos de cair em riba do grosso da judadas. Por resfriados e atalhos, mesmo com aquela cavalhada adestra, tocamos, tocamos. Estrada capaz de quatro, lado a lado.p.42; acolá, na virada que principiava a vertente - onde é que estavam uns outros, que chamavam, muito acenando especial. Pois fomos, ligeiro, ver o que, subindo pelo resfriado. p.27; outros dez espalhados na vertente, se podia impedir a passagem de duzentos cavaleiros, pelo resfriado...p.41; E como cada vereda, quando beirávamos, por seu resfriado, acenava para a gente um fino sossego sem notícia - todo buritizal e florestal: ramagem e amar em água. E que, com nosso cansaço, em seguir, sem eu nem saber, o roteiro de Deus nas serras dos Gerais, p.140; Nós estávamos na beira do cerrado, cimo donde a ladeirinha do resfriado principia. p.172.

\begin{tabular}{|l|l|l|l|}
\hline $\begin{array}{l}\text { NATUREZA } \\
\text { DOS } \\
\text { SEMAS } \\
\text { CONCEPTUAIS } \\
\text { FORMADORES }\end{array}$ & Classe de Noemas & Caracterização Semântico-Conceptual & Natureza \\
\cline { 2 - 5 } & Conceptus & $\begin{array}{l}\text { Caminho que desce das chapadas beirando } \\
\text { as veredas. }\end{array}$ & Traços biofísicos \\
\cline { 2 - 5 } & Metaconceptus & $\begin{array}{l}\text { Caminho com chão claro molhado, } \\
\text { porejando aguinhas que acena um fino } \\
\text { sossego. às }\end{array}$ & $\begin{array}{l}\text { Traços culturais ideológicos } \\
\text { modalizantes intencionais }\end{array}$ \\
\cline { 2 - 5 } & Metametaconceptus & $\begin{array}{l}\text { Caminho de Deus,que leva duais } \\
\text { veredas,onde se pode descansar. }\end{array}$ & \\
\hline
\end{tabular}

\begin{tabular}{|l|l|l|l|l|l|}
\hline \multicolumn{2}{|l|}{ SEMAS } \\
$\begin{array}{l}\text { caminho com } \\
\text { ladeira }\end{array}$ & $\begin{array}{l}\text { na serra dos } \\
\text { Gerais }\end{array}$ & na chapada & com buritizal & $\begin{array}{l}\text { que leva para } \\
\text { local de } \\
\text { descanso }\end{array}$ & \\
\hline serve de atalho & & na vertente & com floresta & & \\
\hline serve de estrada & & $\begin{array}{l}\text { que leva à } \\
\text { vereda }\end{array}$ & com ramagem & & \\
\hline é roteiro de Deus & & $\begin{array}{l}\text { com água para } \\
\text { beber }\end{array}$ & $\begin{array}{l}\text { com chão } \\
\text { porejando } \\
\text { aguinhas }\end{array}$ & & \\
\hline & & & & \\
\hline
\end{tabular}

Definição do vocábulo-termo RESFRIADO : Roteiro de Deus com ladeira nas encostas das chapadas, que serve de atalho, com chão claro molhado que poreja aguinhas e leva às veredas.

Observações: Vocábulo-termo corrente ainda hoje na região de Cordisburgo, conforme nos indica José Oswaldo dos Santos, foi descrito por Rosa em sua carta ao tradutor italiano: "O resfriado só tem uma grama rasteira...Em geral, as estradas, na região, preferem ou precisam de ir, por motivos óbvios, contornando as chapadas, pelos resfriados, de vereda em vereda. (Aí, talvez, a etimologia da designação: vereda.)" CTI, p.41. 
Significado no dicionário Houaiss: Regionalismo: Brasil. Uso:informal. 1 um tanto maluco; que se encontra fora do juízo, confuso, atordoado ou transtornado; azoratado 2 dominado por aborrecimento, indignação ou sentimento de raiva; aborrecido, apoquentado, indignado. Aurélio: Bras., MG. Pop. Adoidado, amalucado. 2. Genioso, irascível, indignado.

Contextualizações: 1) Zé Bebelo - ah. Se o senhor não conheceu esse homem, deixou de certificar que qualidade de cabeça de gente a natureza dá, raro de vez em quando. Aquele queria saber tudo, dispor de tudo, poder tudo, tudo alterar. Não esbarrava quieto. Seguro já nasceu assim, zureta, arvoado, criatura de confusão.p.33; 2) Onde é que estará? Na Pavoã? Alguém tem de ir lá..." - "É ele... É ver a vida: quem pensava? E é homem danado, zuretado..." "Está a favor da gente... E ele sabe guerrear..." E era. p.39; 3) [...] pois, em nome deles, mesmo, eu sou deste parecer. A condena seja: sem tardança! Zé Bebelo, mesmo zureta, sem responsabilidade nenhuma, verte pemba, perigoso. A condena que vale, legal, é um tiro p.122; 4) Ninguém nem mal me ouvia, achavam que eu era zureta ou impostor, ou vago em aluado. Mesmo eu não era capaz de falar a ponto. A conversa dos assuntos para mim mais importantes amolava o juízo dos outros, caceteava. Eu nunca tinha certeza de coisa nenhuma. p.172; 5) Estava falando contra comigo, reclamando, gritou uma ofensa. Homem zuretado, esbraseia os olhos. Eu, senhor de minhas inteligências, como fica dito. p.235

\begin{tabular}{|l|l|l|l|}
\hline $\begin{array}{l}\text { NATUREZA } \\
\text { DOS } \\
\text { SEMAS } \\
\text { CONCEPTUAIS } \\
\text { FORMADORES }\end{array}$ & Classe de Noemas & Caracterização Semântico-Conceptual & Natureza \\
\cline { 2 - 4 } & Conceptus & Homem fora do seu juízo. & Traços biofísicos \\
\cline { 2 - 4 } & Metaconceptus & Criatura arvoada, ofensiva e de confusão. & $\begin{array}{l}\text { Traços culturais } \\
\text { ideológicos }\end{array}$ \\
\cline { 2 - 4 } & Metametaconceptus & $\begin{array}{l}\text { Homem transtornado, envenenado e } \\
\text { perigoso. }\end{array}$ & $\begin{array}{l}\text { Traços culturais } \\
\text { modalizantes intencionais }\end{array}$ \\
\hline
\end{tabular}

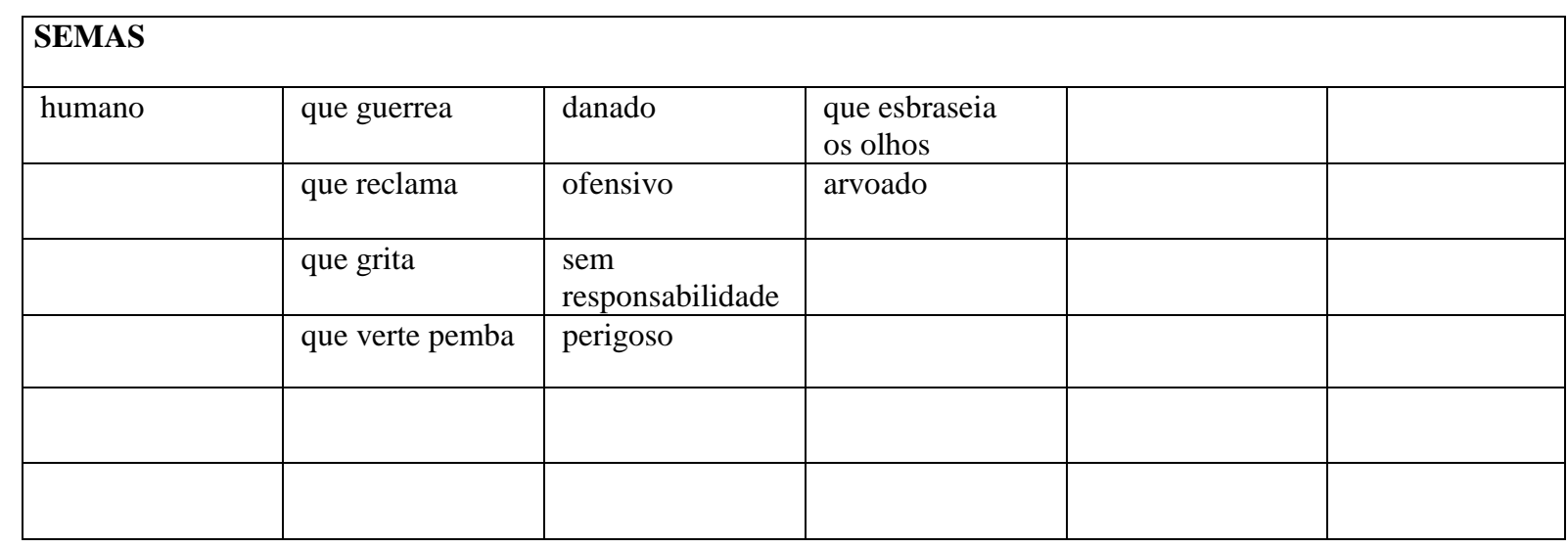

Definição do vocábulo-termo ZURETADO: Criatura arvoada, que guerrea, esbraseia os olhos e verte pemba.

Observações: Em Martins, pemba: Sentido obscuro, talvez veneno, significado que Paulo Rónai dá ao termo sem oferecer comentário ou explicação. 
Significado no dicionário Houaiss: crosta de terra não lavrada. Rubrica: geologia. m.q. banco de areia. Martins: Banco de areia persistente ou temporário produzido por aluviões nos estuários e no baixo curso dos rios; ilhota//Bras., var. de coroa.

Contextualizações:1) Aquele Malinácio era o guardador: com as munições bem encobertadas. Defronte da casa dele, mesmo, e para cima e para baixo, o rio possuía as croas de areia - cada qual com seu nome, que os remadores do dasVelhas botavam, e que todos tanto conheciam. Três croas e uma ilha. Mas uma delas três, maior, também sendo meio ilha: isto é, ilha de terra, na parte de baixo, com grandes pedras e árvores, e suja de matinho, capim, o alecrim viçoso remolhando suas folhagens nágua e o bunda-de-negro verde vivente; e croa, só de areia, na parte de cima. Uma crôacom-ilha, que é conforme se diz. A Crôa-com-Ilha do Malinácio, dita. A lá, que aonde estava o oculto, a gente ia em canoa, baldear a munição.p.63; O rio, objeto assim a gente observou, com uma croa de areia amarela, e uma praia larga: manhãzando, ali estava re-cheio em instância de pássaros.p.64

\begin{tabular}{|l|l|l|l|}
\hline $\begin{array}{l}\text { NATUREZA } \\
\text { DOS }\end{array} \begin{array}{l}\text { SEMAS } \\
\text { CONCEPTUAIS }\end{array}$ & Classe de Noemas & Caracterização Semântico-Conceptual & Natureza \\
\cline { 2 - 4 } & Conceptus & $\begin{array}{l}\text { Meio ilha, meio croa de areia formada rio } \\
\text { abaixo e rio acima. }\end{array}$ & Traços biofísicos \\
\cline { 2 - 4 } & Metaconceptus & $\begin{array}{l}\text { Meio croa de areia amarela com praia larga, } \\
\text { meio ilha, com vegetação e pássaros. }\end{array}$ & $\begin{array}{l}\text { Traços culturais } \\
\text { ideológicos }\end{array}$ \\
\cline { 2 - 4 } & Metametaconceptus & $\begin{array}{l}\text { Meio croa em cima, meio ilha na parte de } \\
\text { baixo, com grandes pedras e árvores, suja de } \\
\text { matinho, capim, alecrim viçoso e re-cheia } \\
\text { em instância de pássaros. }\end{array}$ & $\begin{array}{l}\text { Traços culturais } \\
\text { modalizantes } \\
\text { intencionais }\end{array}$ \\
\hline
\end{tabular}

\begin{tabular}{|c|c|c|c|c|c|}
\hline \multicolumn{5}{|l|}{ SEMAS } & \\
\hline $\begin{array}{l}\text { formação de } \\
\text { areia }\end{array}$ & $\begin{array}{l}\text { encontradas rio } \\
\text { abaixo e rio } \\
\text { acima }\end{array}$ & $\begin{array}{l}\text { cada uma tem } \\
\text { um nome }\end{array}$ & $\begin{array}{l}\text { chega-se até a } \\
\text { croa de canoa }\end{array}$ & têm pedras & \\
\hline banco de areia & $\begin{array}{l}\text { são meio croa e } \\
\text { meio ilha }\end{array}$ & $\begin{array}{l}\text { os nomes são } \\
\text { dados pelos } \\
\text { remadores do } \\
\text { rio }\end{array}$ & & têm árvores & \\
\hline \multirow[t]{3}{*}{ ilhota } & $\begin{array}{l}\text { têm croa de } \\
\text { areia na parte } \\
\text { de cima }\end{array}$ & & & têm capim & \\
\hline & têm praia larga & & & $\begin{array}{l}\text { tem alecrim } \\
\text { viçoso }\end{array}$ & \\
\hline & $\begin{array}{l}\text { tem ilha de } \\
\text { terra na parte } \\
\text { de baixo }\end{array}$ & & & $\begin{array}{l}\text { têm o bunda- } \\
\text { de-negro verde } \\
\text { vivente }\end{array}$ & \\
\hline
\end{tabular}

Definição do vocábulo-termo CROA-COM-ILHA: Pequenas ilhas com nomes dados pelos remadores, encontradas rio abaixo e rio acima, meio croas de areia na parte de cima, meio ilha de terra na parte de baixo, com praia larga suja de matinho, pedras, árvores, alecrim viçoso e pássaros. 
Significado no dicionário Houaiss: quizila Sinônimos ver sinonímia de amofinação, desinteligência e repulsão. SILVA PINTO: Guigilha sf. He o mesmo que anthipatia.

Contextualizações: 1) Do que de uma feita, por me valer, eu entendi o casco de uma coisa. Que, quando eu estava assim, cada de-manhã, com raiva de uma pessoa, bastava eu mudar querendo pensar em outra, para passar a ter raiva dessa outra, também, igualzinho, soflagrante. E todas as pessoas, seguidas, que meu pensamento ia pegando, eu ia sentindo ódio delas, uma por uma, do mesmo jeito, ainda que fossem muito mais minhas amigas e eu em outras horas delas nunca tivesse tido quizília nem queixa. P.107; 2) Dum fato, na hora, me lembrei: do que tinham me contado, da vez em que Medeiro Vaz avistou um enfermo desses num goiabal. O homem tinha vindo lamber de língua as goiabas maduras, por uma e uma, no pé, com o fito de transpassar o mal para outras pessoas, que depois comessem delas. Uns assim fazem. Medeiro Vaz, que era justo e prestimoso, acabou com a vida dele. Isso contavam, já de dentro do meu ouvido. A quizília que em mim, ânsia forte: o lázaro devia de feder; onde estivesse, adonde fosse, lambuzava pior do que lesma grande, e tudo empestava da doença amaldita. Arte de que as goiabas de todo goiabal viravam fruta peçonhenta... - e d'eu dar no gatilho: lei leal essa, de Medeiro Vaz... p.226

\begin{tabular}{|l|l|l|l|}
\hline $\begin{array}{l}\text { NATUREZA } \\
\text { DOS } \\
\text { SEMAS } \\
\text { CONCEPTUAIS } \\
\text { FORMADORES }\end{array}$ & Classe de Noemas & Caracterização Semântico-Conceptual & Natureza \\
\cline { 2 - 4 } & Conceptus & Antipatia por alguém. & Traço psicossocial \\
\cline { 2 - 5 } & Metaconceptus & $\begin{array}{l}\text { Casco por alguém que tudo empesta } \\
\text { depressa. }\end{array}$ & Traços culturais ideológicos \\
\cline { 2 - 5 } & Metametaconceptus & Ânsia forte de dar no gatilho. & $\begin{array}{l}\text { Traços culturais } \\
\text { modalizantes intencionais }\end{array}$ \\
\hline
\end{tabular}

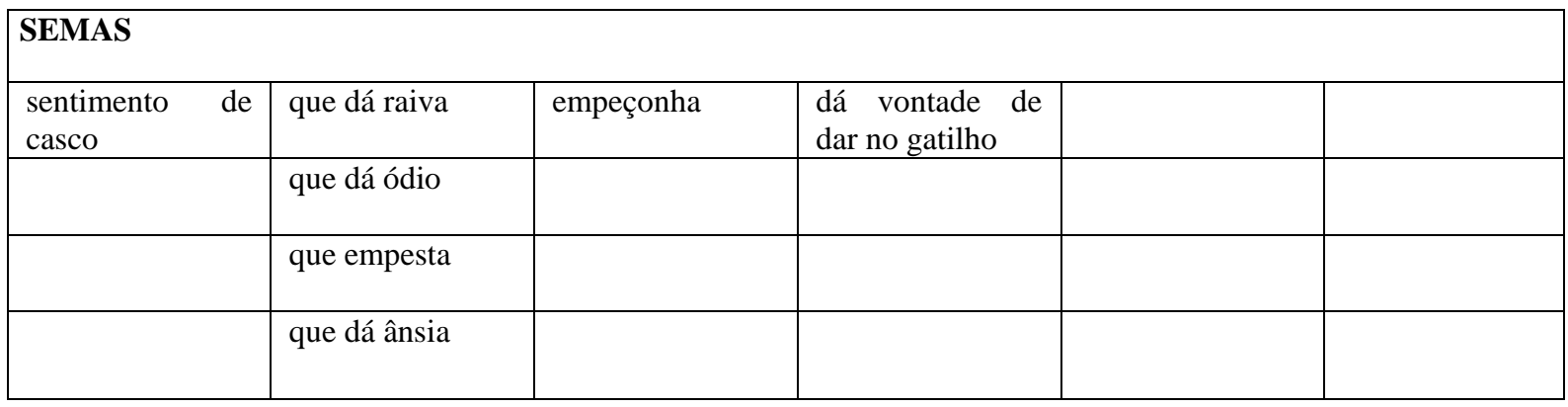

Definição do vocábulo-termo QUIZíLIA: Forte repugnância por alguém que se alastra como peste e dá vontade de matar.

Observações: 
Significado no dicionário Houaiss: diz-se de ou cão que se adestrou para rastrear a caça. Rastrear :Seguir o rastro ou a pista de (caça, suspeito, fugitivo etc.); rastejar2 fazer investigação a respeito de; inquirir, investigar, rastejar.

Contextualizações: 1) Constante que com a gente estavam três bons rastreadores - Suzarte, Joaquim Beiju e Tipote esse Tipote sabia meios de descobrir cacimbas e grotas com o bebível, o Suzarte desempenhava um faro de cachorromestre, e Joaquim Beiju conhecia cada recanto dos gerais, de dia e de noite, referido deletreado, quisesse podia mapear planta.p.19; 2) E nós estávamos perdidos. Nenhum poço não se achava. Aquela gente toda sapirava de olhos vermelhos, arroxeavam as caras. A luz assassinava demais. E a gente dava voltas, os rastreadores farejando, procurando.p.21; 3) Repartiu os homens em quatro pelotões - três drongos de quinze, e um de vinte - em cada um ao menos um bom rastreador. - "Carecemos de quatro buzinas de caçador, para os avisos..p.40; 4) o Quipes, sujeito ligeiro, capaz de abrir num dia suas quinze léguas, cavalos que haja; Joaquim Beiju, rastreador, de todos esses sertões dos Gerais sabente; o Tipote, que achava os lugares d'água, feito boi geralista ou buriti em broto de semente;p.145; 5) o Suzarte, outro rastreador, feito cão cachorro ensinado, boa pessoa; p.145; 6) E foi se saber: o Suzarte e o Tipote, e outros, com o João Vaqueiro, rastreavam redobrados, onde em redor, remediando o mundo a alho e faro. Tudo eles achavam, tudo sabiam; em pouquinhas horas, tudo tradiziam. O chão, em lugares, guardava molde marcado dos cascos de muitíssimas reses, calcados para um rumo só - um caminho eito. Aqueles rastros tinham vigorado por cima da derradeira lama da derradeira chuva. E - de quantidade e de quanto tinha chovido - eles liam, no capim e nos regos de enxurradas, e na altura da cheia já rebaixada, a deixa, beiradas do ribeirão. Pelo comido pastado das reses, também, muito se reconhecia. Aos passos dos cavaleiros e cachorros. As pessoas da casa tinham viajado para a banda de oestes. Mas o gado, escolhendo por si e sem tocada, mas depois de solto por boa regra, pegara ida espaçada mais virante acima, aonde devia haver, para se lamber, salinas de barreiro. E bastantes outras coisas eles decifravam assim, vendo espiado o que de graça no geral não se vê. Capaz de divulgarem até os usos e costumes das criaturas ausentes, dizer ao senhor se aquele seô Habão era magro ou gordo, seria forreta ou mão-aberta, canalha inteirado ou razoável homem-debem. Porque, dos centos milhares de assuntos certos que parecem mágica de rastreador, só com o Tipote e o Suzarte o senhor podia rechear livro.p.181/182

\begin{tabular}{|l|l|l|l|}
\hline NATUREZA & Classe de Noemas & Caracterização Semântico-Conceptual & Natureza \\
\cline { 2 - 4 } $\begin{array}{l}\text { SEMAS } \\
\text { CONCEPTUAIS }\end{array}$ & Conceptus & $\begin{array}{l}\text { Homem que acompanha os vaqueiros nos } \\
\text { gerais, que conhece os meios de encontrar } \\
\text { água, de decifrar o quanto choveu, saber o } \\
\text { rastro do gado, bem como usos e costumes } \\
\text { das pessoas ausentes }\end{array}$ & Traços biofísicos \\
\cline { 2 - 5 } & Metaconceptus & $\begin{array}{l}\text { Homem com faro de cão-mestre que sabe } \\
\text { os meios de prover as necessidades dos } \\
\text { vaqueiros como se fosse mágica }\end{array}$ & $\begin{array}{l}\text { Traços culturais } \\
\text { ideológicos }\end{array}$ \\
\cline { 2 - 5 } & Metametaconceptus & $\begin{array}{l}\text { Homem capaz de ver espiado o que de de } \\
\text { graça, no geral, não se vê }\end{array}$ & $\begin{array}{l}\text { Traços culturais } \\
\text { modalizantes intencionais }\end{array}$ \\
\hline
\end{tabular}

\begin{tabular}{|l|l|l|l|l|l|}
\hline SEMAS & $\begin{array}{l}\text { com faro de } \\
\text { cachorro mestre }\end{array}$ & $\begin{array}{l}\text { conhece os gerais } \\
\text { de dia e de noite }\end{array}$ & abre caminho mapeia planta & $\begin{array}{l}\text { acompanha } \\
\text { vaqueiro }\end{array}$ \\
\hline & feito cão ensinado & $\begin{array}{l}\text { conhecedor do } \\
\text { caminho }\end{array}$ & $\begin{array}{l}\text { divulga usos e } \\
\text { costumes }\end{array}$ & encontra água & prova \\
\hline & feito boi geralista & & & & informa \\
\hline & feito broto de buriti & & & & traduz tudo capim \\
\hline
\end{tabular}

\footnotetext{
Definição do vocábulo-termo RASTREADOR: Homem que conhece os gerais de dia e de noite, acompanha os vaqueiros pelo sertão com faro de cão mestre, e vê espiado, o que de graça no geral, não se vê.

Observações: Leonardo Arroyo comenta a habilidade característica de Tipote, vedor de água, habilidade conhecida universalmente, que foi trazida ao Brasil pela tradição portuguesa e aqui se juntou aos conhecimentos dos índios, despertando a admiração de viajantes estrangeiros como Max Schmidt. Arroyo, p.201/202; Rosa ainda usa farejadores: "E nem enviei adiante nenhuma patrulha de farejadores - nem Suzarte, Nélson ou o Quipes, que tapejassem; nem o Tipote para trilhar e entender, ver se divulgava os socorros: alguma grota duvidável d'água", onde tapejar, do tupi, não dicionarizado, significa de acordo com Martins, tape, caminho + jara, senhor, para designar os conhecedores de caminho.
} 
Significado no dicionário Houaiss: Datação 1721 cf. RB, que ou aquele que tomba ou faz ${ }^{2}$ tombar. Silva Pinto: O que faz tombo de terra. Tombar: Cahir para hum lado. Derrubar. Fazer Tombo.

Contextualizações: 1) Tombadores. Arre, os tremedais, já viu algum? O chão deles consiste duro enxuto, normal que engana; quem não sabe o resto, vem, pisa, vai avançando, tropa com cavalos, cavalama. Seja sem espera, quando já estão meio no meio, aquilo sucrepa: pega a se abalar, ronca, treme escapulindo, feito gema de ovo na frigideira. Ei! Porque, debaixo da crosta seca, rebole ocultado um semifundo, de brejão engolidor... Pois, em roda dali, João Goanhá dispôs que a gente se amoitasse - três golpes de homens - tocaiando. p.29/ 2)Mesmo assim, Titão Passos ia com uns trinta companheiros reguardar o caminho de vinda, à emboscada, num tombador de pedra.p.91/ 3) E, daí, deu-se. Da banda de longe - lá pelo tombador de pedra, onde nossa gente com Titão Passos estavam escondidos para a esparrela - foi um tirotear forte, fogo por salvas. p.97

\begin{tabular}{|l|l|l|l|}
\hline $\begin{array}{l}\text { NATUREZA } \\
\text { DOS }\end{array}$ & Classe de Noemas \\
CONCEPTUAIS & Caracterização Semântico-Conceptual & Natureza \\
\cline { 2 - 4 } FORMADORES & Conceptus & $\begin{array}{l}\text { Chão duro de pedra com brejo debaixo da } \\
\text { crosta seca. Tremedal. }\end{array}$ & Traços biofísicos \\
\cline { 2 - 4 } & Metaconceptus & $\begin{array}{l}\text { Brejão engolidor que engana, ocultado } \\
\text { debaixo do chão duro e enxuto. }\end{array}$ & Traços culturais ideológicos \\
\cline { 2 - 4 } & Metametaconceptus & $\begin{array}{l}\text { Chão com semi-fundo que rebole, ronca e } \\
\text { treme escapulindo, feito gema de ovo na } \\
\text { frigideira. }\end{array}$ & $\begin{array}{l}\text { Traços culturais } \\
\text { modalizantes intencionais }\end{array}$ \\
\hline
\end{tabular}

\begin{tabular}{|l|l|l|l|l|l|}
\hline \multicolumn{2}{|l|}{ SEMAS } & que engana & $\begin{array}{l}\text { feito gema de } \\
\text { ovo }\end{array}$ & $\begin{array}{l}\text { para amoitar } \\
\text { bandos }\end{array}$ & \\
\hline espécie de chão & duro & sucrepa & & para tocaiar & \\
\hline com crosta seca & enxuto & abala & & para esconder & \\
\hline de pedra & & ronca, treme & & & \\
\hline com brejão & & escapule & & & \\
\hline & & engole & & & \\
\hline
\end{tabular}

Definição do vocábulo-termo TOMBADOR: Brejão semi-fundo, debaixo da crosta seca e dura de terra, que sucrepa, treme e quando menos se espera e se está meio no meio escapule feito gema de ovo. 
Significado no dicionário Houaiss: arco luminoso que se origina em fenômenos físicos e meteorológicos e é produzido quando a luz solar é refratada, dispersa e internamente refletida por gotículas de água provenientes da chuva e suspensas na atmosfera [É visível como um conjunto de bandas coloridas adjacentes na forma de arcos de circunferência (mais raramente como anéis) com as cores do espectro solar.]

Contextualizações: De Diadorim, aí jaz que descansando do meu lado, assim ouvi: - "Pois dorme, Riobaldo, tudo háde resultar bem..." Antes palavras que picaram em mim uma gastura cansada; mas a voz dele era o tanto-tanto para o embalo de meu corpo. Noite essa, astúcia que tive uma sonhice: Diadorim passando por debaixo de um arco-íris. Ah, eu pudesse mesmo gostar dele - os gostares...p.21

\begin{tabular}{|l|l|l|l|}
\hline $\begin{array}{l}\text { NATUREZA } \\
\text { DOS }\end{array}$ & Classe de Noemas \\
CONCEPTUAIS & Caracterização Semântico-Conceptual & Natureza \\
\cline { 2 - 5 } & Conceptus & $\begin{array}{l}\text { Arco colorido que aparece no céu depois da } \\
\text { chuva. }\end{array}$ & Traços biofísicos \\
\cline { 2 - 5 } & Metaconceptus & $\begin{array}{l}\text { Arco colorido que aparece no céu em } \\
\text { seguida à chuva e faz mudar de sexo quem } \\
\text { passar debaixo dele. }\end{array}$ & $\begin{array}{l}\text { Traços culturais } \\
\text { ideológicos }\end{array}$ \\
\cline { 2 - 5 } & Metametaconceptus & $\begin{array}{l}\text { Arco colorido que aparece no céu em } \\
\text { seguida à chuva e por astúcia em uma } \\
\text { sonhice faz mudar de sexo quem passar } \\
\text { debaixo dele. }\end{array}$ & $\begin{array}{l}\text { Traços culturais } \\
\text { modalizantes intencionais }\end{array}$ \\
\hline
\end{tabular}

\begin{tabular}{|c|c|c|c|c|c|}
\hline \multicolumn{6}{|l|}{ SEMAS } \\
\hline $\begin{array}{l}\text { fenômeno óptico e } \\
\text { meteorológico }\end{array}$ & $\begin{array}{l}\text { formação } \\
\text { colorida em arco }\end{array}$ & no céu & $\begin{array}{l}\text { aparece depois } \\
\text { da chuva }\end{array}$ & $\begin{array}{l}\text { é motivo de } \\
\text { superstição }\end{array}$ & $\begin{array}{l}\text { passar por baixo } \\
\text { dele faz mudar } \\
\text { de sexo }\end{array}$ \\
\hline & $\begin{array}{l}\text { com as cores do } \\
\text { espectro solar }\end{array}$ & no horizonte & & & \begin{tabular}{lr}
\multicolumn{2}{l}{ faz o menino ou } \\
menina mudar \\
de sexo \\
passem \\
baixo
\end{tabular} \\
\hline & $\begin{array}{l}\begin{array}{l}\text { espécie de luz } \\
\text { colorida }\end{array} \\
\end{array}$ & & & & \\
\hline & & & & & \\
\hline & & & & & \\
\hline
\end{tabular}

Definição do vocábulo-termo: ARCO-ÍRIS: Arco colorido que se aparecer no céu depois da chuva, faz mudar de sexo o menino ou menina que passar debaixo dele, por astúcia de uma sonhice.

Observações: Os colonizadores portugueses trouxeram a superstição de que o arco-íris, em seguida à chuva, faz mudar de sexo o menino ou menina que passar debaixo dele; em Grande Sertão, Riobaldo sonha, apaziguando seu amor arvoado, pois na teoria dos sonhos, o arco-íris é símbolo de calma ou apaziguamento moral. Arroyo, p.126. 
Ficha Etnoterminológica $n^{\circ} 21 \quad$ Vocábulo-termo: CABAÇA BEM TAPADA E BREADA Ocorrências: 1

Significado no dicionário Houaiss: Cabaça: planta da fam. das cucurbitáceas e a uma da fam. das bignoniáceas. Recipiente feito do fruto dessa planta, a que ger. se corta a ponta da extremidade menor para retirar a polpa e para servir de gargalo, us. para guardar alimentos, sementes, água doce, vinho etc. Brear; Rubrica: termo de marinha. Cobrir de breu (as costuras do navio). Derivação: por analogia. Revestir de matéria semelhante ao breu.

Contextualizações: Pois tinha sido que eu acabava de sarar duma doença, e minha mãe feito promessa para eu cumprir quando ficasse bom: eu carecia de tirar esmola, até perfazer um tanto - metade para se pagar uma missa, em alguma igreja, metade para se pôr dentro duma cabaça bem tapada e breada, que se jogava no São Francisco, a fim de ir, Bahia abaixo, até esbarrar no Santuário do Santo Senhor Bom-Jesus da Lapa, que na beira do rio tudo pode.p.45

\begin{tabular}{|c|c|c|c|}
\hline \multirow{4}{*}{$\begin{array}{l}\text { NATUREZA } \\
\text { DOS } \\
\text { SEMAS } \\
\text { CONCEPTUAIS } \\
\text { FORMADORES }\end{array}$} & Classe de Noemas & Caracterização Semântico-Conceptual & Natureza \\
\hline & Conceptus & $\begin{array}{l}\text { Recipiente feito do fruto seco da cabaceira, } \\
\text { sem miolo, utilizado para guardar alimentos, } \\
\text { bebidas, sementes, esmolas. }\end{array}$ & Traços físico culturais \\
\hline & Metaconceptus & $\begin{array}{l}\text { Recipiente revestido com breu, com esmola } \\
\text { dentro, jogado no rio São Francisco para } \\
\text { cumprimento de promessa. }\end{array}$ & $\begin{array}{l}\text { Traços culturais } \\
\text { ideológicos }\end{array}$ \\
\hline & Metametaconceptus & $\begin{array}{l}\text { Recipiente com esmola dentro, para } \\
\text { cumprimento de promessa, tapado, revestido } \\
\text { com breu, jogado no rio São Francisco, que } \\
\text { corre até esbarrar na beira do Santuário de } \\
\text { Bom-Jesus da Lapa, que tudo pode. }\end{array}$ & $\begin{array}{l}\text { Traços culturais } \\
\text { modalizantes intencionais }\end{array}$ \\
\hline
\end{tabular}

\begin{tabular}{|c|c|c|c|c|c|c|}
\hline \multicolumn{7}{|l|}{ SEMAS } \\
\hline vegetal & recipiente oco & tapado & $\begin{array}{ll}\text { onde } & \text { se } \\
\text { coloca } & \\
\text { esmola } & \end{array}$ & $\begin{array}{l}\text { corre no rio } \\
\text { São Francisco }\end{array}$ & $\begin{array}{l}\text { para cumprir } \\
\text { promessa }\end{array}$ & $\begin{array}{l}\text { por graça } \\
\text { alcançada }\end{array}$ \\
\hline \multirow{3}{*}{$\begin{array}{l}\text { fruto da } \\
\text { cabaçeira }\end{array}$} & seco & breado & & Bahia abaixo & & \\
\hline & sem a polpa & & & jogado no rio & & \\
\hline & & & & $\begin{array}{l}\text { em direção ao } \\
\text { Santuário do } \\
\text { Bom Jesus da } \\
\text { Lapa }\end{array}$ & & \\
\hline & & & & & & \\
\hline
\end{tabular}

Definição do vocábulo-termo CABAÇA TAPADA E BREADA: Recipiente feito do fruto da cabaceira, sem miolo, tapado e breado, com esmola dentro, jogado ao rio São Francisco que corre em direção ao Santuário de Bom Jesus da Lapa, como promessa em sinal de alguma graça alcançada.

Observações: Arroyo cita a forte influência do catolicismo aliado à religiosidade africana sobrevivente entre os moradores dos Gerais e das margens do rio São Francisco, onde o costume de oferecer cabaças com dinheiro persistiu por muito tempo, e do qual ainda hoje, naquelas regiões se tem notícia, conforme nos informa José Oswaldo dos Santos (Brasinha); em Grande Sertão há várias ocorrência da palavra cabaça como recipiente onde se carrega líquidos, geralmente água. 
Significado no dicionário Martins: Bruxaria, feitiço; pacto com o diabo. L. C.. Cascudo: Amuleto, patuá, mandinga defensora, bentinho. Arroyo: de caborje, nome de vários peixes (tamanduá, camboatá, combó ou bacu).

Contextualizações:1) Depois, o Reinaldo disse: eu fosse lavar corpo, no rio. Ele não ia. Só, por acostumação, ele tomava banho era sozinho no escuro, me disse, no sinal da madrugada. Sempre eu sabia de tal crendice, como alguns procediam assim esquisito - os caborjudos, sujeitos de corpo-fechado. No que era verdade. Não me espantei.p.66 / 2) Vai, um dia, coisas dessas que às vezes acontecem, esse Davidão pegou a ter medo de morrer. Safado, pensou, propôs este trato a um outro, pobre dos mais pobres,chamado Faustino: o Davidão dava a ele dez contos de réis, mas, em lei de caborje - invisível no sobrenatural - chegasse primeiro o destino do Davidão

morrer em combate, então era o Faustino quem morria, em vez dele. E o Faustino aceitou, recebeu, fechou. Parece que, com efeito, no poder de feitiço do contrato ele muito não acreditava.

\begin{tabular}{|l|l|l|l|}
\hline $\begin{array}{l}\text { NATUREZA } \\
\text { DOS } \\
\text { SEMAS } \\
\text { CONCEPTUAIS } \\
\text { FORMADORES }\end{array}$ & Classe de Noemas & Caracterização Semântico-Conceptual & Natureza \\
\cline { 2 - 4 } & Conceptus & Pacto com o diabo. & Psicofato cultural \\
\cline { 2 - 4 } & Metaconceptus & Feitiço para fechar o corpo. & $\begin{array}{l}\text { Psicofato cultural } \\
\text { ideológico. }\end{array}$ \\
\cline { 2 - 4 } & Metametaconceptus & $\begin{array}{l}\text { Feitiço invisível que se contrata com o } \\
\text { diabo para se defender de algum mal. }\end{array}$ & $\begin{array}{l}\text { Traços culturais } \\
\text { modalizantes intencionais }\end{array}$ \\
\hline
\end{tabular}

\begin{tabular}{|c|c|c|c|c|c|}
\hline \multicolumn{6}{|l|}{ SEMAS } \\
\hline espécie de pacto & é crendice & $\begin{array}{l}\text { procedimento } \\
\text { esquisito }\end{array}$ & para aceitar & $\begin{array}{l}\text { para fechar o } \\
\text { corpo }\end{array}$ & $\begin{array}{ll}\text { para } & \text { defesa } \\
\text { contra } & \text { algum } \\
\text { mal } & \\
\end{array}$ \\
\hline espécie de trato & é sobrenatural & $\begin{array}{l}\text { procedimento } \\
\text { invisível }\end{array}$ & para receber & & \\
\hline $\begin{array}{l}\text { espécie de } \\
\text { contrato }\end{array}$ & & & para fechar & & \\
\hline \multicolumn{6}{|l|}{ espécie de feitiço } \\
\hline & & & & & \\
\hline & & & & & \\
\hline
\end{tabular}

Definição do vocábulo-termo CABORJE: Espécie de feitiço invisível contratado com o diabo, por um sujeito, para fechar seu corpo, para defesa contra algum mal.

Observações: Como lembra Gustavo Barroso: "sempre na tradição, se diz que o bandido tinha pauta com o diabo, que andava com breves livradores de bala, ao pescoço, com caborjes (feitiço) contra facadas”. Arroyo, p.132. 
Significado no dicionário Houaiss: Substantivo masculino. Regionalismo: Minas Gerais. m.q. caipira ('roceiro'); Aurélio: [de quadrumano, alt. pros. de.] S.m. Bras., MG.V. Caipira(1). Caipora, morador do mato, ente fantástico da mitologia tupi; indivíduo que pela simples presença provoca infelicidade, azar. Indivíduo azarado, infeliz.

Contextualizações: 1) As criaturas [...] Como que marquei: que a gente ter encontrado aquele catrumanos, e conversado com eles, desobedecido a eles - isso podia não dar sorte. A hora tinha de ser o começo de muita aflição, eu pressentia. Raça daqueles homens era diverseada distante, cujos modos e usos, mal ensinada. Esses, mesmo no trivial, tinham capacidade para um ódio tão grosso, de muito alcance, que não custava quase que esforço nenhum deles; [...], p.176; 2) [...]e isso com os poderes da pobreza inteira e apartada; e de como assim estavam menos arredados dos bichos do que nós mesmos estamos: porque nenhumas más artes do demônio regedor eles nem divulgavam. Só o mau fato de se topar com eles, dava soloturno sombrio. Apunha algum quebranto. Mas mais que, por conosco não avirem medida, haviam de ter rogado praga. De pensar nisso, eu até estremecia; o que estremecia em mim: terreno do corpo, onde está a raiz da alma. p.176; 3) Aqueles homens eram orelhudos, que a regra da lua tomava conta deles, e dormiam farejando. E para obra e malefícios tinham muito governo. Aprendi dos antigos. p.176; 4) Capatazia de soprar quente qualquer ódio nas folhas, e secar a árvore; ou de rosnar palavras em buraco pequeno que abriam no chão, tapando depois: para o caminho esperar a passagem de alguém, e a ele fazer mal; ou guardavam um punhado de terra no fechado da mão, no prazo de três noites e três dias, sem abrir, sem largar: e quando jogavam fora aquela terra, em algum lugar, nele com data de três meses ficava sendo uma sepultura. p.176.

\begin{tabular}{|l|l|l|l|}
\hline $\begin{array}{l}\text { NATUREZA } \\
\text { DOS } \\
\text { SEMAS } \\
\text { CONCEPTUAIS } \\
\text { FORMADORES }\end{array}$ & Classe de Noemas & Caracterização Semântico-Conceptual & Natureza \\
\cline { 2 - 4 } & Conceptus & $\begin{array}{l}\text { Homens caipiras, roceiros, muito pobres e } \\
\text { marginalizados }\end{array}$ & Traços biofísicos \\
\cline { 2 - 5 } & Metaconceptus & $\begin{array}{l}\text { Raça de homens diverseada e distante nos } \\
\text { modos e usos, mal ensinada e quase como } \\
\text { bicho }\end{array}$ & $\begin{array}{l}\text { Traços culturais } \\
\text { ideológicos }\end{array}$ \\
\hline
\end{tabular}

\begin{tabular}{|l|l|l|l|l|l|}
\hline SEMAS & $\begin{array}{l}\text { de modos e usos } \\
\text { mal ensinados }\end{array}$ & orelhudos & $\begin{array}{l}\text { de pobreza } \\
\text { inteira e apartada } \\
\text { humanos }\end{array}$ & $\begin{array}{l}\text { topar com eles } \\
\text { dá soloturno } \\
\text { posonem } \\
\text { quebranto }\end{array}$ \\
\hline $\begin{array}{l}\text { diverseados, no chão } \\
\text { distantes }\end{array}$ & $\begin{array}{l}\text { rosnam palavras } \\
\text { paracos que }\end{array}$ & $\begin{array}{l}\text { quase como } \\
\text { bichos }\end{array}$ & & $\begin{array}{l}\text { conversar e } \\
\text { desobedecer não } \\
\text { dá sorte, dá azar }\end{array}$ & rogam praga \\
\hline $\begin{array}{l}\text { capazes de ódio, } \\
\text { obra e malefícios }\end{array}$ & $\begin{array}{l}\text { guardam terra na } \\
\text { mão para que } \\
\text { vire sepultura } \\
\text { onde for jogada }\end{array}$ & $\begin{array}{l}\text { só de pensar } \\
\text { neles a raiz da } \\
\text { alma estremece }\end{array}$ & & & $\begin{array}{l}\text { secam árvores } \\
\text { sopram quente } \\
\text { nas folhas }\end{array}$ \\
\hline
\end{tabular}

Definição do vocábulo-termo CATRUMANOS: Homens orelhudos, que rosnam, diverseados, de modos e usos mal ensinados, capazes de ódio e de malefícios, apõem quebranto e rogam praga, sopram quente nas folhas, secam árvores e guardam terra na mão para que vire sepultura onde for jogada.

Observações: No livro Folclore de Januária, Joaquim Ribeiro assim descreve o catrumano: "homem rústico, atrasado, supersticioso, rico de usos e costumes arcaicos, falando um linguajar originalíssimo" 
Significado no dicionário Houaiss: Regionalismo: Minas Gerais. Uso: informal. Aguardente de cana; cachaça. Etimologia top. Januária (MG), onde inicialmente era fabricada a bebida.

Contextualizações: 1) Tudo em mais paz, me ofereceram: bebi da januária azulosa - um gole me foi; cachaça muito nomeada. p.73; 2) E pedi água. - "Mano velho, bebe, que esta é competente..." - ele riu. O que estava me dando, na cabacinha, era água com cachaça. Bebi. Limpei os beiços. p .97; 3) Ali, o tempo, a rapaziada suava, cuidando nos alambiques, como perfeito se faz. Assim essas cachaças - a vinte-e-seis cheirosa - tomando gosto e cor queimada, nas grandes dornas de umburana. p. 155; 4) Ah, e bebiam, seguro que bebiam as cachaças inteirinhas da Januária. p.178.

\begin{tabular}{|l|l|l|l|}
\hline $\begin{array}{l}\text { NATUREZA } \\
\text { DOS } \\
\text { SEMAS } \\
\text { CONCEPTUAIS } \\
\text { FORMADORES }\end{array}$ & Classe de Noemas & Caracterização Semântico-Conceptual & Natureza \\
\cline { 2 - 4 } & Conceptus & $\begin{array}{l}\text { Cachaça fabricada na cidade de Januária, } \\
\text { porto no rio São Francisco, guardada em } \\
\text { dornas de umburana para tomar sabor e } \\
\text { cor. }\end{array}$ & Traços biofísicos \\
\cline { 2 - 5 } & Metaconceptus & $\begin{array}{l}\text { Vinte-e seis cheirosa, azulosa e muito } \\
\text { nomeada" }\end{array}$ & $\begin{array}{l}\text { Traços } \\
\text { ideológicos }\end{array}$ \\
\cline { 2 - 5 } & Metametaconceptus & $\begin{array}{l}\text { A melhor e mais famosa cachaça de Minas } \\
\text { e provavelmente do Brasil. É um pouco do } \\
\text { sertão. }\end{array}$ & $\begin{array}{l}\text { Traços culturais } \\
\text { modalizantes intencionais }\end{array}$ \\
\hline
\end{tabular}

\begin{tabular}{|l|l|l|l|l|l|}
\hline \multicolumn{2}{|l|}{ SEMAS } & gostosa & $\begin{array}{l}\text { produzida em } \\
\text { Januária }\end{array}$ & $\begin{array}{l}\text { guardadas em } \\
\text { dornas de } \\
\text { umburana }\end{array}$ & para tomar cor \\
\hline cachaça & Januária & de cor queimada & $\begin{array}{l}\text { cuidada em } \\
\text { alambiques }\end{array}$ & $\begin{array}{l}\text { guardada pela } \\
\text { rapaziada }\end{array}$ & para tomar sabor \\
\hline & $\begin{array}{l}\text { da marca } \\
\text { Vinte-e-seis }\end{array}$ & cheirosa & competente & & \\
\hline & & & & & \\
\hline & & & & & \\
\hline
\end{tabular}

Definição do vocábulo-termo Januária: Cachaça famosa azulosa e cheirosa, produzida em Januária, no sertão de Minas, guardada em dornas de umburana, também conhecida como Vinte-e-seis; é um pouco do sertão.

Observações: A cachaça faz parte do cotidiano do sertanejo. Noraldino Lima destaca que "a cana de açúcar que dá em abundância, por toda a parte é a alegria do sertanejo: dela vem a rapadura e a januária vida do remo e calor dos batuques". Arroyo, p.159. Em Grande Sertão, temos Riobaldo que diz beber para ter coragem: "Fui aprendendo a achar graça no dessossego. Aprendi a medir a noite em meus dedos. Achei que em qualquer hora eu podia ter coragem. Isso que vem, de mansinho, com uma risada boa, cachaça aos goles, dormida com a gente encostado em coronha de sua arma"p.112. Em carta a E. Bizarri, de 28/10/63, Rosa explica: "A melhor e mais famosa cachaça, de Minas Gerais e, provavelmente do Brasil. Fabricada na cidade de Januária, porto no rio de São Francisco" e, em 07/04/64, Rosa declara: "É um pouco do Sertão, em todo caso", referindo-se a "três pícolas garrafinhas da januária", encomendadas para presentear o amigo tradutor. (p.149) 
Significado no dicionário Aulete 1. Ação ou resultado de redemoinhar, de adquirir movimento rotativo em espiral, esp. de água ou vento. 2. Movimento de rotação ou em espiral; Redemoinho; Rodamoinho; Turbilhão; Vórtice. 3. Movimento giratório de uma rajada de vento, ger. ocasionado pela mudança súbita de direção.

Contextualizações: 1) Bem, o diabo regula seu estado preto, nas criaturas, nas mulheres, nos homens. Até: nas crianças - eu digo. Pois não é ditado: "menino - trem do diabo"? E nos usos, nas plantas, nas águas, na terra, no vento... Estrumes. ... O diabo na rua, no meio do redemunho... p.12; 2 )Do vento que vinha, rodopiado. Redemoinho: o senhor sabe - a briga de ventos. O quando um esbarra com outro, e se enrolam, o doido espetáculo. A poeira subia, a dar que dava escuro, no alto, o ponto às voltas, folharada, e ramaredo quebrado, no estalar de pios assovios, se torcendo turvo, esgarabulhando. p.111; 3) Redemonho!" - o Caçanje falou, esconjurando. - Vento que enviesa, que vinga da banda do mar... - Diadorim disse. p.11;4) Mas o Caçanje não entendia que fosse: redemunho era d'Ele - do diabo. O demônio se vertia ali, dentro viajava." p.111

\begin{tabular}{|l|l|l|l|}
\hline $\begin{array}{l}\text { NATUREZA } \\
\text { DOS } \\
\text { SEMAS } \\
\text { CONCEPTUAIS } \\
\text { FORMADORES }\end{array}$ & Classe de Noemas & Caracterização Semântico-Conceptual & Natureza \\
\cline { 2 - 4 } & Conceptus & $\begin{array}{l}\text { Encontro de ventos que se esbarram, } \\
\text { rodopiando }\end{array}$ & Traços biofísicos \\
\cline { 2 - 5 } & Metaconceptus & $\begin{array}{l}\text { Briga de ventos, que enviesam, que } \\
\text { vingam da beira do mar }\end{array}$ & Traços culturais ideológicos \\
\cline { 2 - 5 } & Metametaconceptus & Onde o Sujo verte, viaja e mora. & $\begin{array}{l}\text { Traços culturais modalizantes } \\
\text { intencionais }\end{array}$ \\
\hline
\end{tabular}

\begin{tabular}{|c|c|c|c|c|c|}
\hline \multicolumn{6}{|l|}{ SEMAS } \\
\hline briga de ventos & $\begin{array}{l}\text { vento } \\
\text { rodopiado }\end{array}$ & $\begin{array}{l}\text { o demônio } \\
\text { verte ali dentro }\end{array}$ & $\begin{array}{l}\text { o doido } \\
\text { espetáculo }\end{array}$ & $\begin{array}{l}\text { dono dele } \\
\text { mora dentro }\end{array}$ & $\begin{array}{l}\text { o diabo regula seu } \\
\text { estado preto na rua }\end{array}$ \\
\hline $\begin{array}{l}\text { um vento } \\
\text { esbarra com } \\
\text { outro }\end{array}$ & $\begin{array}{l}\text { vento que vinga } \\
\text { da banda do } \\
\text { mar }\end{array}$ & $\begin{array}{l}\text { o demônio viaja } \\
\text { dentro dele }\end{array}$ & $\begin{array}{l}\text { estalar de pios } \\
\text { assovios }\end{array}$ & $\begin{array}{l}\text { o dono dele é o } \\
\text { Sujo }\end{array}$ & \\
\hline $\begin{array}{l}\text { vento que } \\
\text { enviesa }\end{array}$ & & & $\begin{array}{l}\text { torcendo turvo } \\
\text { esgarabulhando }\end{array}$ & $\begin{array}{l}\text { o redemunho é } \\
\text { d'Ele }- \text { do } \\
\text { diabo }\end{array}$ & \\
\hline $\begin{array}{l}\text { ventos que se } \\
\text { enrolam }\end{array}$ & & & & & \\
\hline
\end{tabular}

Definição do vocábulo-termo REDEMOINHO: Movimento dos ventos pretos que brigam na rua, num doido espetáculo de assovios e pios, esbarrando um com o outro, se enrolando, torcendo turvo, esbugaralhando, lugar onde o diabo mora, verte, viaja e vinga.

Observações: De acordo com Leonardo Arroyo " como uma manifestação da natureza , na configuração universal do animismo, o redemoinho, conforme a crença popular, está carregado de implicações sobrenaturais...é o elemento natural do Diabo...a tradição vem de Beira Alta, Portugal[...] houve em certas regiões brasileiras, como em São Paulo, uma aculturação da crença, trocando-se o indivíduo, isto é, o Diabo pelo Saci, sendo que este poderá ser apanhado com uma peneira no redemoinho que passa" ARROYO, L. A Cultura Popular em Grande Sertão:Veredas. Rio de Janeiro, Livraria José Olímpio, 1984, p.184/185; O termo em inglês para denominar o fenômeno metereológico é dust devil , em tradução literal, poeira do diabo. 


\subsection{Sistematização}

Analisamos, em suas diferentes etapas, o processo de conceptualização de alguns vocábulos-termos do léxico de Grande Sertão: Veredas, processo este que se dá no percurso gerativo da enunciação, constituído por conjuntos de semas conceptuais, os noemas. A análise linguística que desvela representações acerca dos fatos, concepções e visões de mundo, formas de perceber, sentir, pensar e simbolizar a realidade se realiza, como vimos, no nível do discurso manifestado e os conteúdos conceptual e semântico são materializados nos traços específicos ou nos conceitos de cada unidade lexical.

$\mathrm{Na}$ concepção de universos de discursos, a percepção da realidade, a atribuição de valor e a denominação originam-se, como vimos, nas qualidades conceituais da cognição, o patamar em que se processa o conceito. "Conceituar é o processo de construção de um modelo mental que corresponde a um recorte cultural e em seguida da escolha da estrutura léxica que pode manifestá-lo, o conceito é resultado de uma interpretação de fatos naturais elou culturais" ${ }^{\prime 192}$.

A denominação, produto do fazer persuasivo do sujeito enunciador, aquele que fala ou escreve com intenção de comunicar, engendra-se a partir do continuum amorfo, passando pelo nível noêmico até o lexemático, num processo onomasiológico do discurso manifestado, e integra o processo de modalização do discurso, conforme já estudamos em Barbosa. Testemunha um modelo social e cultural de construção do mundo. A denominação é, enfim, a forma material de apropriação dos elementos conceptualizados pelo grupo linguístico e pertence portanto, ao grupo que os conceptualizou.

Pudemos observar que o conceptus, em sentido amplo, parte em sua trajetória, do natural em direção ao cultural: as denominações que pertencem ao léxico de uso da língua geral são aculturadas no sertão dos gerais; a visão subjetiva do grupo expande seus significados, com o acréscimo de semas conceptuais formadores, que se organizam em dois subconjuntos: os de natureza cultural e ideológica e aqueles ideológicos de natureza modalizante e intencional.

Vimos que o primeiro conjunto, o conjunto do conceptus é de natureza universal, disponível para qualquer comunidade humana, portanto, situa-se enquanto modelo mental, em um nível pré-cultural.

192 BARBOSA, Maria Aparecida. Da formação do Conceptus à Estruturação Semântica Lexical. Boletim da Associação Brasileira de Linguística, v.26, Fortaleza, 2001, p. 154. 
$\mathrm{Na}$ análise de vereda, o paradigma de vocábulo-termo desta Dissertação, o modelo mental do campo semântico paisagem geográfica se realiza nessa etapa. Os modelos mentais produzidos simultaneamente distanciam-se do denominado conceptus do primeiro nível, e o grupo dos sertanejos de Rosa realiza um recorte sociocultural que assume papel de referente exclusivo para esse grupo. Esse recorte define e sustenta sua visão de mundo, agora em nível pré-semiótico e transsemiótico passível de atualização nas semiótica-objeto verbal, não-verbal ou sincréticas do grupo.

Assim, o nosso paradigma vereda abarca o conjunto de lexes privativo do grupo dos sertanejos dos Gerais que, como vimos em Pais, passam a funcionar como matrizes sígnicas ao condensar significações e manifestar-se, no universo de discurso rosiano, engendrando seu sistema semiótico.

As escolhas do grupo sociocultural e do autor definem os traços específicos do vocábulo-termo vereda, seu metaconceptus, conjunto de traços culturais ideológicos que, para nós, que ainda não nos apropriamos desse universo de discurso, ampliam o significado de vereda, pois acrescentamos aos semas caminho, senda, trilha, os seguintes novos semas: local de descanso, local de sombra verde de buritis onde se bebe estável e se pode estudar o juízo dos papagaios, e o conjunto de traços semântico-conceptuais modalizadores intencionais, que resume os demais, um oásis, e integra seu metametaconceptus.

Enfim, este é o vocábulo-termo que no universo de discurso da língua geral, no nível de sistema, está em função de vocábulo. Na vertente etnoliterária do universo de discurso de "Grande Sertão: Veredas" tem o duplo estatuto, de vocábulo e de termo. Além disso, e da maior importância, cada vocábulo-termo se constitui em documento autêntico de identidade de uma parte da vasta realidade brasileira, das raízes sócio-linguísticas e culturais do nosso país e, dos valores sobre os quais se erigiu a concepualização do homem enquanto indivíduo e grupo.

Podemos assim representar as relações de forças expressas na tensão dialética que constitui o sistema linguístico-cultural, documentado pelo léxico rosiano:

Constituição do universo semiótico rosiano / sertanejo: 
t.d

Campos Gerais

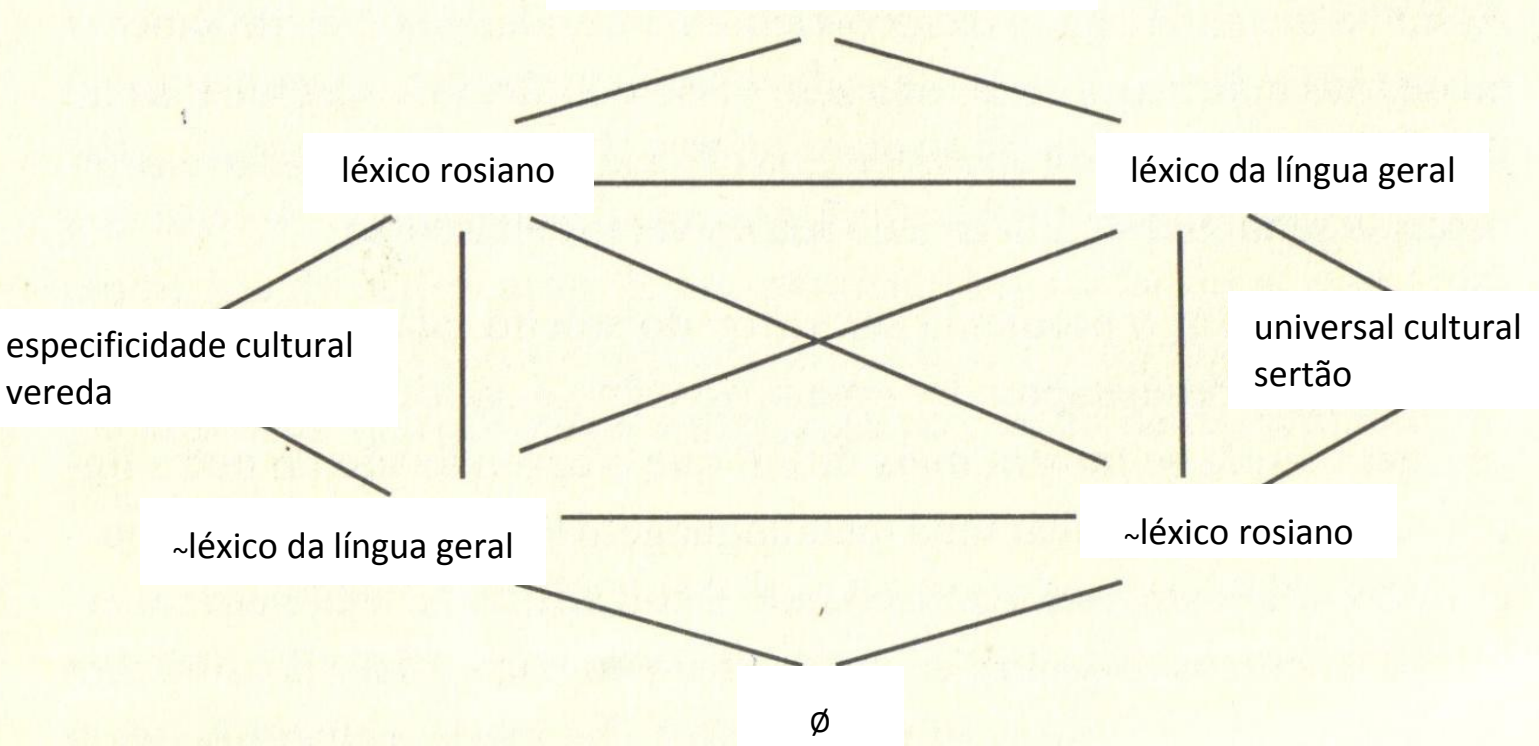

A forma diferente de pensar e sentir o mundo, advinda do universo antropocultural, faz parte da forma linguística particular do grupo que a convencionou, da forma como cada grupo analisa a substância semântica à sua disposição, o que garante o dinamismo lexical, ao estabelecer novas relações em outros universos, ao enriquecê-los com novos elementos.

O conjunto dos universos semióticos elaborados pelos diferentes códigos - a macrossemiótica de um grupo sócio-linguístico-cultural - constitui a sua "visão de mundo". ${ }^{193}$ É essa substância virtual que os grupos linguísticos utilizam para formalizar e estruturar seus diferentes códigos que possibilitam a compreensão do mundo e a comunicação.

$O$ vocábulo- termo, unidade mínima de significação da Etnoterminologia, atualizado no discurso etnoliterário, é símbolo dos temas que subjazem na obra de Rosa, em seu plano mítico, o tema vento, por exemplo. E, vimos, simboliza ao mesmo tempo a cultura do Brasil Central. Os entornos discursivos dos vocábulos-termos analisados em nossas fichas permitem-nos situá-los em um patamar elevado de densidade terminológica no que diz respeito à natureza dos conhecimentos herdados que veiculam, se comparados, por exemplo, aos vocábulos-termos da literatura de cordel, porém, de menor densidade terminológica se comparados aos termos da terminologia da química ou outras áreas de especialidades.

\footnotetext{
${ }^{193}$ BARBOSA, Maria Aparecida. Léxico, Produção e Criatividade. São Paulo: Editora Plêiade, 1996, p.157.
} 


\section{CONCLUSÃO}

Curt Meyer-Clason escreveu a Rosa, quando finalizada sua tradução de Grande Sertão:Veredas para o alemão, que "seu" "Riobaldo fala o alto-alemão"194 pois, na Alemanha não há sertão, e lá a fala do matuto não é conhecida. Assim, tentou superar o insuperável para simular a estrutura linguística interna do texto e o linguajar do interior de Minas, sabendo que "o original é acessível apenas a dois grupos de leitores. De um lado, o habitante de Minas Gerais que compreende intuitivamente a linguagem do sertão, de outro, a pessoa realmente culta, mas apenas com o auxílio de um léxico" ${ }^{195}$. Ressalvou que uma tradução congenial, seria aquela feita depois de uma viagem de pelo menos um ano pelo sertão, seguida de pesquisa na Idade Média alemã, para encontrar em sua riqueza linguística equivalentes idiomáticos aos de Rosa ${ }^{196}$.

Rosa reconhecia a riqueza do Português falado no Brasil em relação ao Português falado em Portugal, já desgastado pelo uso, como afirmou a Günter Lorenz. Considerava, também, a riqueza do Português do Brasil como incalculável, [...] por razões etnológicas e antropológicas"197

Retomemos ainda uma vez com as pistas que podemos compreender, e que Rosa com humildade procurou detalhar aos seus tradutores e compartilhar com seus leitores, o sertão dos campos gerais semioticamente construído principalmente noroeste de Minas Gerais, até o oeste e sul da Bahia, e Goiás, onde passam a se chamar as gerais, indo até o Piauí e Maranhão.

As imensas chapadas e chapadões abrigam a extensa paisagem inóspita dos cerrados: arvorezinhas enfezadas que se enraízam no solo arenoso, partículas de sílica que tornam a terra árida e abriga a vida em formas agressivas, e embora insistindo longamente na monotonia desértica, na recusa da vida fértil, curva-se, repentinamente, à imposição da natureza, altiva e sábia, e em pleno deserto, dá lugar às veredas. O buriti, a árvore da vida, altaneiro que anuncia o oásis, e o sertanejo que sabe, conhece da água existente, necessidade

\footnotetext{
${ }^{194}$ BUSSOLOTTI, Maria Aparecida F. M. (Org.) João Guimarães Rosa correspondência com seu tradutor alemão. Rio de Janeiro, Editora Nova Fronteira, 2003, p.147.

${ }^{195}$ Ibid., p. 150

${ }^{196}$ Ibid., p. 151

${ }^{197}$ Entrevistas - Guimarães Rosa 2. Disponível em:

< HTTP://www.tirodeletra.com.br/entrevistas/GuimarãesRosa-1965.htm> Acesso em 09 jun. 2011. p.16
} 
primeira do buriti, a espelhar-lhe as folhas verdes. Os animais e pássaros saciando-se da sede, e os resfriados que indicam o chão pedregoso, de grama rasteira e aprazível verde-claro.

O geralista, que mora no alto das chapadas, o veredeiro, que mora nas veredas, porém todos geralistas, vivem os contrastes do tempo das secas, quando o fogo lavra, e o vento arrasta tudo e forma redemoinhos percorrendo o cerrado ressecado, e o tempo das chuvas, quando todo o verde se espalha; as contradições do ser e não ser do sertanejo; do tudo e do nada que tomam de surpresa e espantam o homem e do medo e coragem na grandeza de tudo com que se deparam.

Aí está, então, o sertanejo Guimarães Rosa, como dizia de si mesmo, com sua conceptualização sertaneja da realidade que brota de sua pena. Que vive, sente e percebe o mundo físico e humano e dá forma a ele com toda a significação especial de que se reveste em suas contradições. Significação cujo produto, as grandezas-signos que analisamos, em sua relação de dependência entre o plano de expressão e o plano de conteúdo integra os dados de experiência do grupo de sertanejos do sertão dos gerais, para construir semioticamente sua realidade.

O insulamento fez com que a cultura popular herdada se mantivesse intacta em sua essência, e o vocabulário do sertanejo refletisse seu falar sedimentado, sofrendo poucas alterações ao longo do tempo, exarando a profunda feição arcaizante da linguagem trazida pelos colonos portugueses, precursores da época clássica, no século XVI, misturada à língua indígena e à língua dos escravos trazidos da África, que durante a fase áurea da extração de minérios formaram a grande maioria da população. O grupo étnico idiossincrático balizou os limites indecifráveis para o forasteiro, não apenas no léxico, mas nos usos e costumes, no seu sistema de crenças, nas tradições, mitos e lendas, e em hábitos seculares.

A realização semântica reflete, pois, a conceptualização étnica do sertanejo e os aspectos geográficos da região que ele habita e que Rosa se encarregou de conceituar: "O sertão está por toda parte".

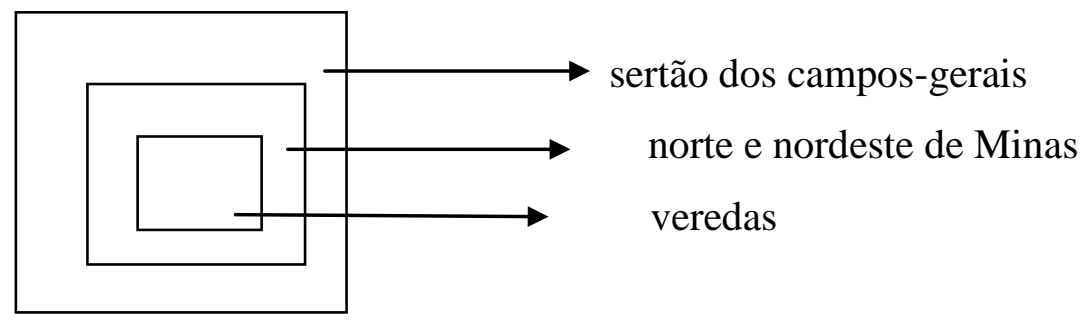


De fato, temos descrita a ambientação de uma parte da cultura brasileira, que constrói os significados de um espaço único, por isto símbolo verdadeiro de tudo que condensa em seu interior e que o homem reconstrói em sua essência, como podemos observar na concepção rosiana sertaneja projetada sobre o homem do sertão, que nada mais é que o próprio homem concebido em seu meio.

O geralista sertanejo, vaqueiro ou jagunço estão visceralmente ligados a esse ambiente, que se desenha em seu modo particular de senti-lo, de enfrentá-lo, sobretudo no modo de representá-lo em seus mistérios, naquilo que entende e em seguida é incapaz de explicar.

Desse modo, o valor da palavra reside, no léxico de Grande Sertão, não apenas da "expressão, cantiga ou frase, legítima, original, com a força de verdade e autenticidade que vem da origem", ${ }^{198}$ dos casos mesmos, transmitidos oralmente pela população que foram aproveitados na obra rosiana. Ao transplantar suas pesquisas para seus textos, ao abrigo das denominações, Rosa realça significantes amalgamados a conceitos portadores de exclusividades semânticas que se erigem na própria especificidade que nomeia os seres.

A hipótese definida em nossa introdução, de que mesmo as palavras de uso em língua geral assumem significado específico em Grande Sertão: Veredas, pode ser comprovada na análise semântico-conceptual realizada em nossas fichas. As palavras usadas pelos sertanejos de Rosa são palavras da língua geral, cuja dupla significação não está ao alcance de quem não seja sertanejo de Rosa.

É nessa exclusividade semântica que a fronteira existente entre o vocábulo e o termo das linguagens de especialidades torna-se densa, palpável, comprovada enfim, se comparada a outros discursos etnoliterários, e é, nesses limites, que se apresenta o vocábulo-termo, no qual o autor encontra a palavra em todo seu vigor, não desgastada pelo uso impróprio.

Propusemos a analisar as denominações do léxico de Grande Sertão: Veredas a partir da perspectiva Etnoterminológica, com o objetivo de compreender como a realidade fenomênica se reflete na axiologia de um grupo sócio-linguístico-cultural e no de Rosa, o autor.

Verificamos, sobretudo, a partir da análise das palavras escolhidas, que a gênese do vocábulo-termo reside em grande medida nas especificidades linguísticas regionais que desenham etnicamente a identidade de um grupo.

\footnotetext{
${ }^{198}$ GALVÃO, Walnice Nogueira. Rapsodo do Sertão: da lexicogênise à mitopoese. In: Cadernos de Literatura Brasileira. São Paulo: Instituto Moreira Salles, 2006, p.192
} 
Esta Dissertação analisou o registro das palavras tais como são utilizadas pelos falantes da região dos gerais, principalmente norte e nordeste de Minas, abordando-as etnoterminologicamente: o que é específico de um grupo, de uma etnia, no que concerne ao seu vocabulário.

Comprovamos que a pancronia se sustenta e subsiste na dialética entre dois termos contrários e não contraditórios, diacronia e sincronia e que a predominância de um desses termos depende da época, do contexto e do autor analisados, e que reflete o vocabulário de um grupo social que utiliza as palavras efetivas, ligadas a um tipo de falar sedimentado, tendo sido o vocabulário por nós analisado se configurado como um conjunto léxico que poucas transformações sofreu com o decorrer do tempo.

Sabemos que em todas as obras de Rosa se verifica, em maior ou menor proporção, o uso das virtualidades que o sistema linguístico oferece aos seus falantes, e a abordagem dos aspectos sociolinguísticos da unidade lexical, convergindo para o semantismo inusitado do vocábulo-termo, podemos concluir, colaborou para melhor caracterizá-la enquanto unidade etnoterminológica.

Verificamos que a análise dos vocábulos-termos de Grande Sertão: Veredas, demonstra, para o ouvinte, o processo de ressemantização da palavra usada na língua geral. Ou seja, novos sememas que enriquecem a própria unidade léxica e também a experiência de quem se aproxima do texto, ao realizar-se em aspectos referenciais, pragmáticos e simbólicos, constituindo-se, simultaneamente, em documento semântico e social de uma cultura.

O significado preciso do vocábulo-termo rosiano destaca e enriquece o discurso etnoliterário presente em Grande Sertão:Veredas, com denominações repletas de etnicidade em sua descrição original do pitoresco, que é, afinal, característica do regionalismo brasileiro.

O fato cultural é estabelecido no universo social, processado e caracterizado em traços semântico- conceptuais que não correspondem aos conceitos que configuram outros universos de discurso. Embora fazendo parte do universo de discurso da língua geral, o grau de informação não compartilhada pelo vocábulo está contido na função termo, rico em traços semânticos que expressam conceitos culturais, próprios do grupo linguístico dos sertanejos dos Gerais.

A criação poética consolida a expressão de uma variedade linguística regional nas denominações: palavras e expressões populares que são cognições particulares do grupo e mantêm laços no eco da herança cultural herdada. Lendas e contos populares que foram ouvidos por várias gerações passaram a ser, intencionalmente escritos por um autor culto, para serem lidos. 
Observamos, além do mais, que as denominações ocupam-se em enfatizar, sobretudo, a paisagem geográfica, o tipo humano e os aspectos místicos e míticos que se configuram em uma porção do Brasil Central. Em resumo, como melhor explica Maria Aparecida Barbosa:

[...] as formas lexicais, nas semióticas-objeto verbais, desempenham o papel de privilegiado instrumento gerador dessa "realidade", de instância configuradora dos fatos estruturáveis. São grandezas-signos, dotadas de expressão e conteúdo, que têm o estatuto de legítimas representantes desses recortes, perante a comunidade. Ao transformar a informação potencial contínua de experiência em significação, essas grandezas-signos tornam-se elas mesmas depositárias de riquíssimo potencial de informação, concernente aos valores do grupo que as criou." ${ }^{199}$

A realidade do sertão e do homem do sertão é convertida em signos densos de traços importantes que revelam seu etnismo. Trata-se de documento histórico, que conforme vimos, ensinou Saussure, é capaz de testemunhar. O sertanejo, geralista ou veredeiro se erige no imo da paisagem geográfica única e as relações estabelecidas nos espaços físico, cultural e social são fatores constitutivos da unidade de língua e conceptualização das diferentes denominações.

199 BARBOSA, Maria Aparecida. Campo Conceitual e Campo Lexical dos Termos Globalização e Mundialização: Relações. In: Revista Brasileira de Linguística, v.10, nº. 1, 1999, ano 26. 


\section{REFERÊNCIAS}

ABREU, J. Capistrano de. Caminhos Antigos e Povoamento do Brasil. Belo Horizonte, Itatiaia: São Paulo: USP, 1988.

AGUIAR, Sergio Marra. As vozes de Chico Buarque em inglês: Tradução e Linguística de Corpus. Tese (Doutorado). FFLCH/USP. São Paulo, 2010.

ALVES, Ieda Maria. A Unidade Lexical Neológica: Do Histórico-Social ao Morfológico. In: As Ciências do Léxico. Campo Grande: UFMS, 2004.

Neologismo. Criação Lexical. São Paulo: Ática, 1994.

ANTONIL, André João. Cultura e Opulência no Brasil por suas drogas e minas. São Paulo: Edusp, 2007.

ARROYO, Leonardo. A Cultura Popular em Grande Sertão: Veredas. Rio de Janeiro, Livraria José Olímpio Editora, 1984.

BARBOSA, Maria Aparecida. Estruturas e Tipologia dos Campos Conceptuais, Campos Léxicos e Campos Lexicais. In: Acta Semiotica et Lingvistica, v.8, São Paulo, Plêiade.

Para uma Etnoterminologia: recortes epistemológicos. Ciência e Cultura

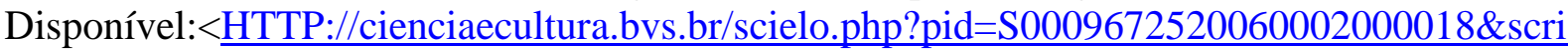
pt=sci $>$ Acesso em: 14 abr. 2011.

Estruturação do conceptus, dos campos conceituais e lexicais, dos co-hipônimos

e dos parassinônimos: semântica cognitiva e semântica lexical. Disponível em: <www.filologia.org.br/anais/anais\%20iv/civ10_59-83.html > Acesso em 09 abr. 2011.

Terminologia Técnico-Científica: confrontos éticos, culturais e políticos. Terminologia Técnico-Científica: Diálogos Transdisciplinares. Disponível em: $<$ http://www..sbcnet.org.br/livro/56ra/banco_conf_simp/textos/MaApBarbosa.htm. Acesso em: 05 abr. 2011.

Cultura Popular Amazônica em Etnoterminologia. Anais da 61ª Reunião Anual da SBPC- Manaus, AM. julho/2009. 
. Etno-terminologia e Terminologia Aplicada: objeto de estudo, campo de atuação. In: ISQUERDO, Aparecida Negri; ALVES, Ieda Maria. (Org.). As ciências do léxico. Lexicologia, Lexicografia. Terminologia. Campo Grande, MS: , 2007, v. 3.

Aspectos conceituais, terminológicos e políticos das denominações: discurso científico e discurso político. In: Anais/Resumos da 57 $^{\circ}$ Reunião Anual da SBPC. São Paulo - SP: SBPC/UECE, 2005. v. 1. p. 1-2.

.Terminologia e Lexicologia: Plurissignificação e Tratamento Transdisciplinar das unidades Lexicais nos Discursos Etnoliterários. In: Revista de Letras, São Paulo, v. 1 /2. jan/dez. 2005, p.103-107. USP, 2001

Sistema Conceptual e Sistema Terminológico. In: Tradterm, São Paulo, Humanitas-

Da Neologia à Neologia em Literatura. In: As Ciências do Léxico, Campo Grande: INEP, UFMS, 2001.

A Construção do Conceito nos Discursos Técnicos-Científicos, nos Discursos Literários e nos Discursos Sociais Não-literários. In: Revista Brasileira de Linguística, São Paulo, Editora Plêiade, 2001, v. 11. nº 1.

Da formação do Conceptus à Estruturação Semântica Lexical. Boletim da Associação Brasileira de Linguística, v.26, Fortaleza, 2001.

Campo Conceitual e Campo Lexical dos Termos Globalização e Mundialização: Relações. In: Revista Brasileira de Linguística, São Paulo, v.10, nº.1, 1999.

Léxico, Produção e Criatividade. São Paulo, Editora Plêiade, 1996.

Língua e Discurso. São Paulo: Global, 1981.

Estudos em Etnoterminologia: As unidades Lexicais na Literatura de Cordel. Universidade de São Paulo. Departamento de Linguística. (Artigo).

.Terminologização, Vocabularização, cientificidade, banalização: relações. In: Acta Semiótica et Lingvistica, v.7, Sociedade Brasileira de Professores de Linguística, Editora Plêiade. 
Léxico e Transdisciplinaridade. Disponível em :

<http://filologia.org.brrevista/artigo/10(30)10.htm. > Acesso em 05 abr. 2011.

Processos de transcodificação entre terminologias técnico-científicas e outras linguagens. In: Acta Semiotica et Lingvistica, SBPL. São Paulo, v. 12, nº 2, ano 31.

BIZARRI, Edoardo. João Guimarães Rosa: correspondências com seu tradutor italiano Edoardo Bizarri. Rio de Janeiro: Nova Fronteira, 2003.

BLUTEAU, Raphael. Vocabulário Portuguez \& Latino. 1728.

HTTP://www.brasiliana.usp.br/dicionarios

BUENO, Francisco da Silveira. A formação Histórica da Língua Portuguesa. São Paulo, 1967.

BUYSSENS, Eric. Semiologia, Linguística e Comunicação. São Paulo: Cultrix, Editora da Universidade de São Paulo, 1972.

CADERNOS DE LITERATURA BRASILEIRA: JOÃO GUIMARÃES ROSA. Instituto Moreira Salles, São Paulo, 2006.

CASTRO, Ney Leandro de. Universo e Vocabulário de Grande Sertão. Rio de Janeiro: Livraria José Olimpio Editora, 1970.

COSERIU, Eugene. Teoria del Lenguaje y Linguiística General. Madrid: Editorial Gredos, 1973.

COSTA, Ana Luiza Martins. Veredas de Viator. In: Cadernos de Literatura Brasileira, João Guimarães Rosa. São Paulo: Instituto Moreira Salles, 2006.

CUNHA, Manuela Carneiro. Parecer sobre os critérios de identidade étnica. In: Antropologia do Brasil: mito, história e etnicidade. São Paulo: Brasiliense/Ed. da UNB, 1986.

DANIEL, Mary Lou. João Guimarães Rosa: Travessia Literária. Rio de Janeiro: Livraria José Olímpio, 1968.

DICK, Maria Vicentina de Paula do Amaral. O nome próprio: significação e referência. (Artigo do curso: Elementos de Etnolinguística e Etnotoponímia. USP, 2009). 
Etnia e etnicidade. Um novo modo de nomear. Projeto ATESP/ATB. In: As ciências do léxico. Campo Grande, Editora UFMS. 2004.

FERREIRA, Aurélio Buarque de Holanda. Novo Dicionário da Língua Portuguesa. Rio de Janeiro: Nova Fronteira, 1975.

GALVÃO, Walnice Nogueira. Rapsodo do Sertão: da lexicogênise à mitopoese. In: Cadernos de Literatura Brasileira João Guimarães Rosa. São Paulo: Instituto Moreira Salles, 2006.

2008.

Mínima Mímica: Ensaios sobre Guimarães Rosa. São Paulo: Companhia das Letras,

Georges Dumézil. Disponível em:< http://www.infopedia.pt/\$georges-dumezil $>$ Acesso em:18 de jun. 2011.

GUILBERT, Louis. La Créativité Lexicale. Librarie Larousse, Paris, 1975.

Theorie du Neologisme. In: Communication de M. L. Guilbert au XXIV Congrès de l'Association, le 24 juillet 1972, Paris.

Guimarães Rosa: Grandes entrevistas, 2. Disponível em:

< HTTP://www.tirodeletra.com.br/entrevistas/GuimarãesRosa-1965.htm> Acesso em 09 de jun. de 2011.

GREIMAS, A.J. A Semântica Estrutural. São Paulo, Cultrix, 1973.

; COURTÉS, J. Dicionário de Semiótica, São Paulo, Contexto, 2008.

HJELMSLEV, Louis. Prolégomènes a une theorie du langage. Les Editions de Minuit. Paris, 1968.

Essays Linguistiques. Les Editions de Minuit. Paris, 1966.

HOLANDA, Sergio Buarque de e outros. História da Civilização Brasileira: A Época Colonial. Tomo I, $2^{\circ}$ v. $7^{\text {a }}$, Rio de Janeiro: Editora Bertrand Brasil, 1993. 
HOUAISS. Dicionário Eletrônico. Disponível em: HTTP:// educação. uol. com.br

LOPES, Edward. Fundamentos da Linguística Contemporânea. São Paulo: Cultrix, 1977.

MACHADO FILHO, Aires da Mata. O negro e o garimpo de Minas Gerais. Belo Horizonte: Itatiaia, 1995.

MARTINS, Nilce Sant`Anna. Arcaísmos em Guimarães Rosa e sua abonação em textos medievais. In: Actas do XIX Congresso Internacional de Linguística e Filoloxia Románicas. Universidade de Santiago de Compostela. Ramon Lourenço, 1989.

O Léxico de Guimarães Rosa. São Paulo: EDUSP, 2008.

MATOS, Raimundo José da Cunha. Corografia Histórica das Minas Gerais. Belo Horizonte: Livraria Itatiaia Editora Limitada, 1981.

MENESES, Adélia Prado. Cores de Rosa: Ensaios sobre Guimarães Rosa. São Paulo: Ateliê Editorial, 2010.

MEYER, Mônica. Ser-tão Natureza: A natureza em Guimarães Rosa. Belo Horizonte: UFMG, 2008.

MOURA, Antonio de Paiva. A Formação Histórica do Noroeste Mineiro. Disponível em:www. asminasgerais.com.br/índex.asp?item=CONTEUDO \&codConteudoRaiz=92. Acesso em: 17 ago. 2010.

MUNANGA, Kabengele. Uma abordagem conceitual das noções da raça, racismo, identidade e etnia. Palestra proferida no $3^{\circ}$. Seminário Nacional. Relações raciais e educacionais. PENESB-RJ. Em: 04 de nov. de 2003.

OLIVEIRA, Roberto Cardoso de. Identidade, Etnia e Estrutura Social. São Paulo, Livraria Pioneira Editora, 1976.

PAIS. Cidmar Teodoro. Considerações sobre a Semiótica das Culturas: uma Ciência da Interpretação: Inserção Cultural, Transcodificações Transculturais. In: Acta Semiotica et Lingvistica, São Paulo, Terceira Margem, 2007. 
Texto, discurso e universo de discurso: Aspectos das Relações entre Enunciação e Enunciado. In: Revista Brasileira de Linguística, São Paulo, v.14, $\mathrm{n}^{\circ}$. 1, Terceira Margem, 2006.

Conceptualização, Interdiscursividade, Arquitexto, Arquidiscurso. In: Revista Philologus. Ano 8, nº 23, Rio de Janeiro, CIFEFIL, 2002.

Conceptualização, denominação, designação: relações. In: Revista de Linguística, São Paulo, v.9, 1997.

Ensaios Semióticos Linguísticos. São Paulo, Vozes, 1997.

O percurso gerativo da enunciação: produtividade léxica e discursiva. In: Confluência. In: Revista do Departamento de Linguística da Unesp -Assis, v.3, Unesp, Assis, 1995.

Dos Estudos pré-linguísticos e linguísticos a semiótica das culturas: abordagem histórico- epistemológica. In: Revista Acta Semiotica et Lingvistica, v.12, no 2, ano 31.

Campos Conceituais, campos lexicais. Da cognição à semiose. htpp://www.filologia.org.br/vinlf/anais/caderno07-09.html. Acesso em: 02 de mai. 2011.

PAIS, Cidmar Teodoro.; BARBOSA, Maria Aparecida. Da análise de aspectos semânticos e lexicais dos discursos etnoliterários à proposição de uma etnoterminologia. In: Matraga, Rio de Janeiro, v. 16, p. 79-100, 2004

. Elementos para uma Tipologia de Sistemas Semióticos. In: Revista Brasileira de Linguística, São Paulo, Livraria Duas Cidades, 1982.

PINTO. Luiz Maria da Silva. Diccionário da Língua Brasileira. 1832. HTTP://www.brasiliana.usp.br/dicionarios

POTTIER, Bernard. Sémantique générale. Presses universitaries de Paris. Paris, 1992.

PROENÇA, Manuel Cavalcanti. Trilhas no Grande Sertão. Cadernos de Cultura. MEC, 1959. 
PROPP,Wladimir.Narratologia.Disponível em: 〈http//:pt.wikipedia.org/wiki/Narratologia> Em 18 ago. 2011.

ROSA, João Guimarães. Grande Sertão: Veredas. Rio de Janeiro: Nova Fronteira, 2006.

RIBEIRO, Joaquim. Folclore de Januária. Rio de Janeiro: MEC, Campanha de defesa do folclore, 1970.

RONCARI, Luiz. O Brasil de Rosa. São Paulo, Ed. UNESP, 2004.

SAMPAIO, Teodoro. O Rio São Francisco e a Chapada Diamantina, org. José Carlos Barreto de Santana. São Paulo: Companhia das Letras, 2002.

SANTOS, Júlia Conceição Fonseca. Nomes dos Personagens em Grande Sertão Veredas. Rio de Janeiro: Instituto Nacional do Livro, 1971.

SAUSSURE, Ferdinand de. Curso de Linguística Geral. São Paulo, Editora Cultrix, 1971.

Scott, M., 2008, WordSmith Tools version 5, Liverpool: Lexical Analysis Software http://www.lexically.net/publications/citing_wordsmith.htm.

SILVA, Antonio de Moraes. Dicionário da Língua Portugueza. 1789.

HTTP://www.brasiliana.usp.br/dicionarios

SPIX e MARTIUS. Viagem pelo Brasil. Tomo I, 1817-1820. São Paulo: Melhoramentos, 1959.

TAUNAY, Afonso de E. Relatos Sertanistas. Belo Horizonte: Itatiaia e Editora da Universidade de São Paulo. v. 34.

TEIXEIRA, José A. O falar Mineiro, In: Revista do Arquivo Municipal, V. XLV, São Paulo, 1938.

WINNIE, Martin. Stylistics : corpus approaches. Oxford University, 2005. 
VASCONCELOS, Diogo. História Antiga das Minas Gerais, $4^{\mathrm{a}}$ ed. Belo Horizonte: Editora Itatiaia, v.188.

VILELA, Mário. O léxico da simpatia. Porto, INIC, 1980.

XISTO, Pedro. Guimarães Rosa em Três Tempos. São Paulo, Imprensa Oficial do Estado. CEC, Comissão de Literatura. 